\title{
UNNES
}

\section{BENTUK DAN PERUBAHAN FUNGSI SENI PERTUNJUKAN TARI OPAK ABANG \\ DESA PASIGITAN KECAMATAN BOJA \\ KABUPATEN KENDAL}

\author{
SKRIPSI \\ untuk memperoleh gelar Sarjana Pendidikan \\ Program Studi Pendidikan Seni Tari

$\begin{array}{ll} & \text { Oleh } \\ \text { Nama } & : \text { Frihastyayu Bintyar Mawasti } \\ \text { NIM } & : \text { 2501413096 } \\ \text { Program Studi } & : \text { Pendidikan Seni Tari } \\ \text { Jurusan } & : \text { Pendidikan Seni Drama Tari dan Musik }\end{array}$

FAKULTAS BAHASA DAN SENI UNIVERSITAS NEGERI SEMARANG 2017 


\section{PERSETUJUAN PEMBIMBING}

Skripsi ini telah disetujui oleh pembimbing untuk diajukan ke Sidang Panitia Ujian Skripsi.

Semarang, 10 Juli 2017

Menyetujui,

Pembimbing I

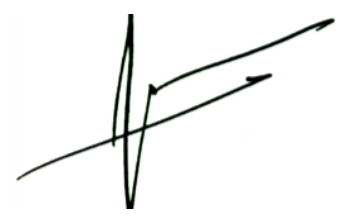

Dra. Malarsih, M.Sn

NIP.196106171988032001
Pembimbing II

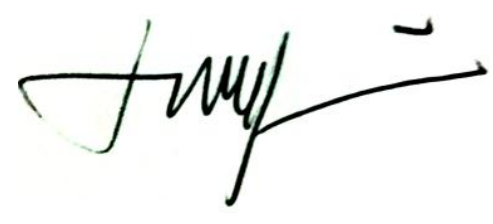

Usrek Tani Utina, S.Pd. MA.

NIP. 198003112005012002 


\section{PENGESAHAN KELULUSAN}

Skripsi ini telah dipertahankan di hadapan sidang Panitia Ujian Skripsi Jurusan Seni Drama Tari dan Musik, Fakultas Bahasa dan Seni, Universitas Negeri Semarang.

$$
\begin{array}{ll}
\text { Hari } & : \text { Kamis } \\
\text { Tanggal } & : 13 \text { Juli } 2017
\end{array}
$$

Prof. Dr. M. Jazuli, M.Hum. ～(NIP: 196107041988031003) Ketua

Abdul Rachman, S.Pd. M.Pd. ～(NIP: 198001202006041002) Sekretaris

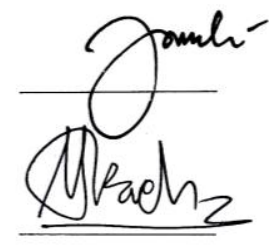

Dra. Eny Kusumastuti, M.Pd. ～(NIP: 196804101993032001) Penguji I

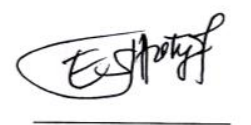

Usrek Tani Utina, S.Pd. MA. ～(NIP. 198003112005012002) Penguji II/Pembimbing II

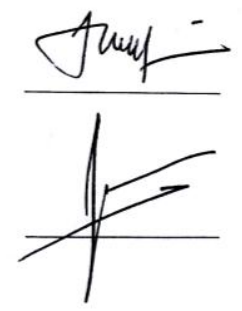

Dra. Malarsih, M.Sn.

(NIP.196106171988032001) Penguji III/Pembimbing I

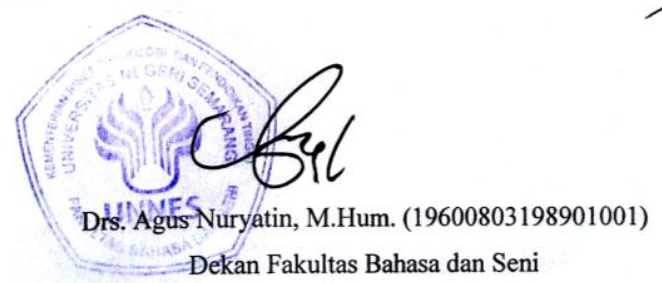




\section{PERNYATAAN}

Saya menyatakan bahwa skripsi saya yang berjudul "Bentuk dan Perubahan Fungsi Seni Pertunjukan Tari Opak Abang Desa Pasigitan Kecamatan Boja Kabupaten Kendal”, saya tulis dalam rangka memenuhi syarat untuk memperoleh gelar Sarjana Pendidikan adalah benar-benar merupakan karya saya sendiri yang dihasilkan setelah melakukan penelitian, bimbingan, diskusi dan pemaparan ujian. Semua kutipan baik langsung maupun tidak langsung, baik yang diperoleh dari sumber pustaka, media elektronika, wawancara langsung maupun sumber lainnya, telah disertai keterangan mengenai identitas narasumbernya sebagaimana etika penulisan karya ilmiah pada umumnya.

Demikian pernyataan ini dibuat agar dapat digunakan sebagaimana mestinya.

Semarang, 10 Juli 2017

Yang membuat pernyataan

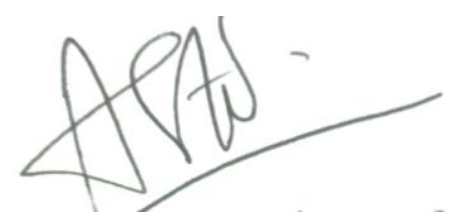

Frihastyayu Bintyar Mawasti

NIM. 2501413096 


\section{MOTTO DAN PERSEMBAHAN}

\section{Motto:}

1. "Menyeberangi lautan tak dapat dilakukan hanya dengan berdiri menatapnya." - Rabindranath Tagore (1861-1941), sastrawan India.

2. "Percaya pada yang kita lakukan dan lakukan apa yang kita percaya." Frihastyayu Bintyar Mawasti (2017).

\section{Persembahan:}

Skripsi ini saya persembahkan kepada:

1. Almamater tercinta Universitas Negeri Semarang.

2. Kedua orang tua saya yang segala pengorbanannya tidak pernah dapat saya ungkapkan dengan katakata. 


\section{KATA PENGANTAR}

Syukur Alhamdulilah penulis panjatkan kepada Allah SWT. yang senantiasa memberkati dan memberikan jalan, sehingga penulis dapat menyelesaikan skripsi ini dengan baik. Skripsi ini disusun sebagai tugas akhir belajar dan syarat guna memperoleh gelar Sarjana Pendidikan yang berjudul "Bentuk dan Perubahan Fungsi Seni Pertunjukan Tari Opak Abang Desa Pasigitan Kecamatan Boja Kabupaten Kendal."

Berkenaan dengan penulisan skripsi ini, penulis menyampaikan ucapan terima kasih dan penghargaan yang setinggi-tingginya untuk bantuan dan dukungan dari banyak pihak yang telah memungkinkan selesainya penyusunan maupun penyajian skripsi ini, kepada:

1. Prof. Dr. Fathur Rohman, M.Hum., Rektor Universitas Negeri Semarang yang telah memberikan kesempatan untuk menyelesaikan studi S1.

2. Prof. Dr. Agus Nuryatin, M.Hum., Dekan Fakultas Bahasa dan Seni yang telah memberikan izin penelitian.

3. Dr. Udi Utomo, M.Si., Ketua Jurusan Pendidikan Seni Drama Tari dan Musik yang telah memberikan kesempatan menulis dan menyelesaikan skripsi.

4. Dra. Malarsih, M.Sn., sebagai Dosen Pembimbing I dan Usrek Tani Utina, S.Pd. MA., sebagai Dosen Pembimbing II yang telah memberikan arahan sekaligus bimbingan untuk penulisan skripsi.

5. Para Dosen Jurusan Pendidikan Seni Drama Tari dan Musik yang telah menularkan ilmu pengetahuan serta keterampilan selama studi S1. 
6. Bapak Aris Salamun beserta grup Sri Langen Budaya Bumi Desa Pasigitan yang telah meluangkan waktunya untuk melayani wawancara terkait tentang penelitian skripsi.

7. Dewi Purnama Sari, Vina Amalia, sahabat-sahabat saya yang dapat menerima diri ini apa adanya dan selalu menemani dikala senang maupun susah

8. Nimas Agustin, Gangsar Kamujo, Gilang Surya, Dwi Prasetyo, Ido Rima, dan Mbak Izza, yang turut membantu penulisan skripsi ini

Penulis berharap skripsi ini dapat dikembangkan lagi sebagai dasar oleh para peneliti ke depan dalam bidang penelitian terkait bentuk dan fungsi seni pertunjukan tari. Penulis menerima dengan senang hati segala bentuk kritik maupun saran yang membangun.

Semarang, 10 Juli 2017

Penulis 


\section{SARI}

Mawasti, Frihastyayu Bintyar. 2017. Bentuk dan Perubahan Fungsi Seni Pertunjukan Tari Opak Abang Desa Pasigitan Kecamatan Boja Kabupaten Kendal. Skripsi, Jurusan Pendidikan Seni Drama Tari dan Musik, Fakultas Bahasa dan Seni, Universitas Negeri Semarang. Pembimbing I: Dra. Malarsih, M.Sn. Pembimbing II: Usrek Tani Utina, S.Pd. MA.

Kata kunci: Bentuk, Fungsi, Seni Pertunjukan, Tari Opak Abang

Tari Opak Abang merupakan tarian rakyat yang berasal dari Desa Pasigitan, Kecamatan Boja, Kabupaten Kendal. Peneliti tertarik dengan bentuk dan fungsi pertunjukan Tari Opak Abang karena Tari Opak Abang memiliki banyak amanat di dalam syair lagunya. Penelitian ini menggunakan pendekatan kualitatif dengan metode deskriptif. Teknik keabsahan data yang digunakan adalah triangulasi. Analisis data yang digunakan terdiri dari tiga alur, yaitu: reduksi data, penyajian data, dan penarikan kesimpulan. Teknik pengumpulan data yang digunakan yaitu teknik observasi, wawancara, dan dokumentasi.

Hasil penelitian mengemukakan bahwa Tari Opak Abang berkembang di Desa Pasigitan sejak tahun 1956. Pertunjukan Tari Opak Abang memiliki 4 urutan sajian, yaitu: 1) Gayung Seribu Gayung; 2) Opak-Opak; 3) Terang Bulan; dan 4) Bunga Rampai. Tari Opak Abang memiliki tema keagamaan dan perjuangan. Gerak Tari Opak Abang merupakan gerak murni. Iringan Tari Opak Abang menggunakan nada diatonis dengan alat musik rebana 2 buah, bass drum 1 buah, kecrek 1 buah, dan biola/violin 1 buah. Tata rias Tari Opak Abang menggunakan rias korektif, dengan atribut busana berupa 1) Plisir (irah-irahan) dengan bulu mentok di ujung; 2) Selempang; 3) Slepe (sabuk); 4) Baju lengan panjang; 5) Celana panjang; 6) Kaos kaki berwarna putih; 7) Kain songket;

Sampur/Selendang; 9) Kipas dari kertas emas untuk telinga; 10) Kacamata hitam; dan 11) Kain penutup kepala. Pementasan Tari Opak Abang menggunakan halaman rumah warga dengan pencahayaan general light dan lampu bohlam putih. Tata suara pada pertunjukan Tari Opak Abang menggunakan sound system berupa wireless, keyboard amplifier, dan wireless microphone. Penari Tari Opak Abang berjumlah 4 orang, dan pemusik sekaligus sindhen berjumlah 7 orang. Penonton yang menikmati pertunjukan Tari Opak Abang berasal dari semua kalangan, baik yang awam atau berkecimpung dalam dunia seni tari. Pertunjukan Tari Opak Abang berfungsi sebagai sarana hiburan, akan tetapi pertunjukan Tari Opak Abang juga mengalami perubahan pada beberapa fungsi lainnya dalam kurun tahun 1956 hingga tahun 2017, yaitu: sarana upacara, sarana pertunjukan, syiar agama Islam, dan media informasi seputar kemerdekaan Indonesia.

Berdasarkan hasil penelitian dan pembahasan, penulis memberikan saran untuk bentuk pertunjukan Tari Opak Abang agar menambah variasi gerakan dengan tempo yang bervariasi agar pertunjukan terlihat lebih menarik. Tari Opak Abang sebaiknya tidak hanya digunakan sebagai sajian hiburan, melainkan bisa ditampilkan untuk propaganda ketika pemilu kepala daerah Kabupaten Kendal. 


\section{DAFTAR ISI}

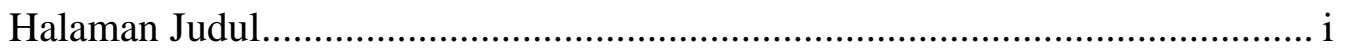

Persetujuan Pembimbing........................................................................ ii

Pengesahan Kelulusan........................................................................... ii

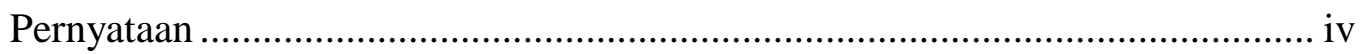

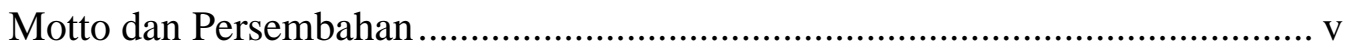

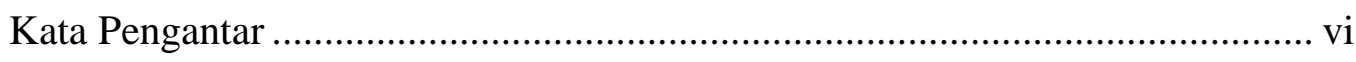

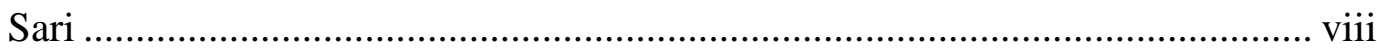

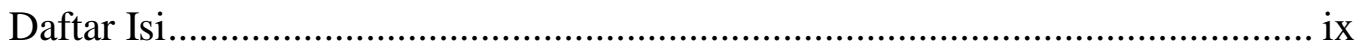

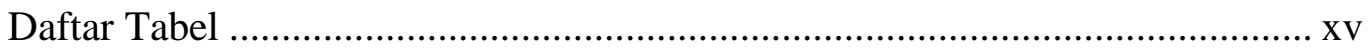

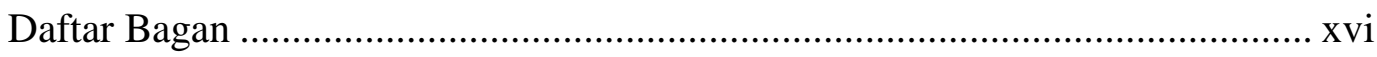

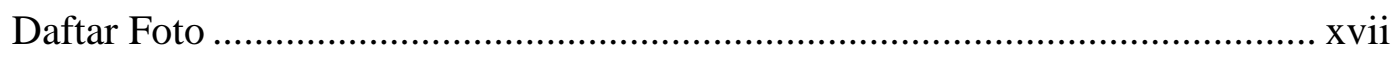

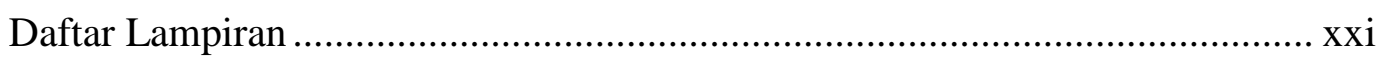

BAB I PENDAHULUAN .................................................................................. 1

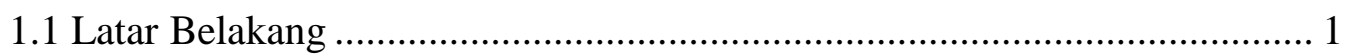

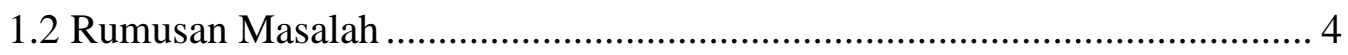

1.3 Tujuan Penelitian ............................................................................. 4

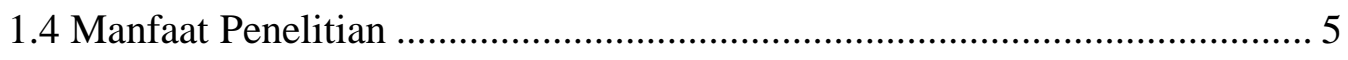

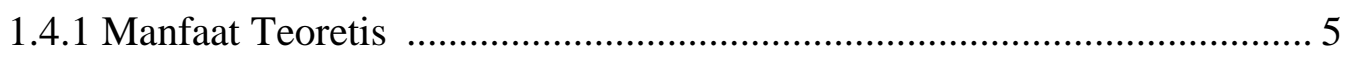

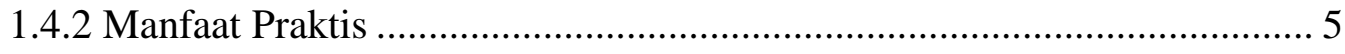

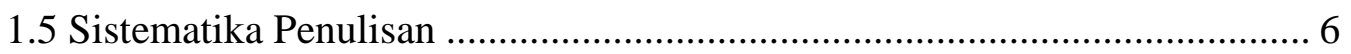


BAB II TINJAUAN PUSTAKA DAN LANDASAN TEORETIS ............... 8

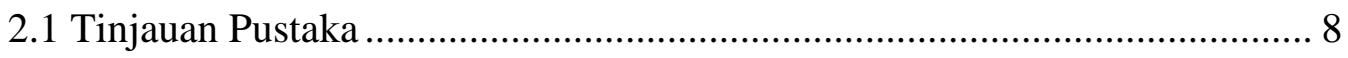

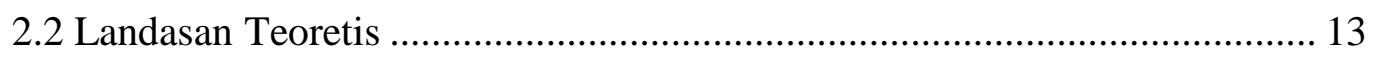

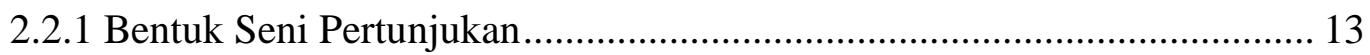

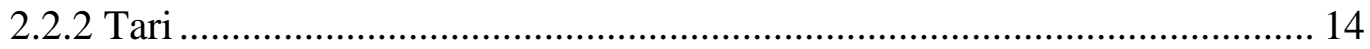

2.2.2.1 Unsur-unsur Pendukung Pertunjukan Tari.......................................... 15

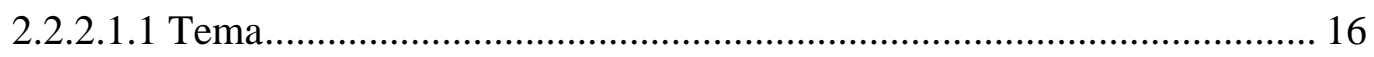

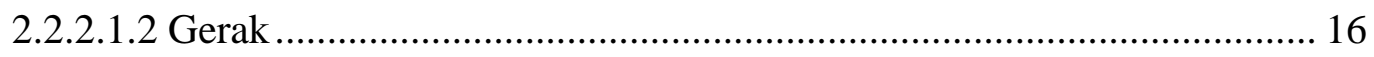

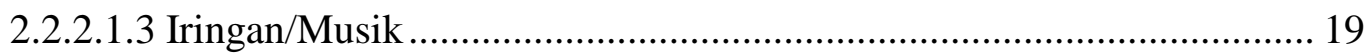

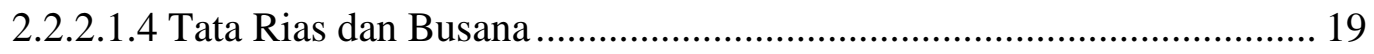

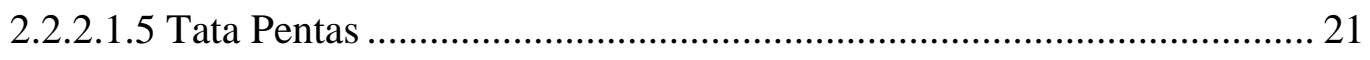

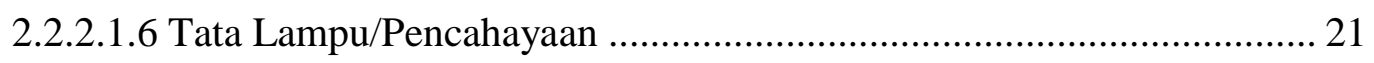

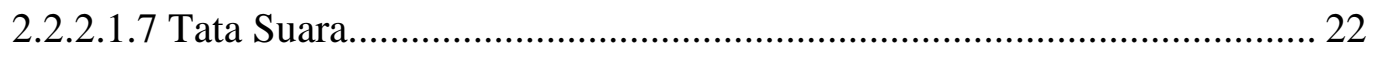

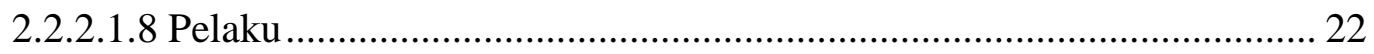

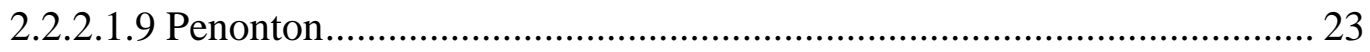

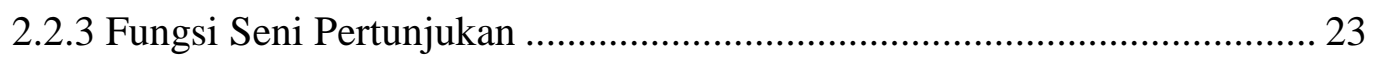

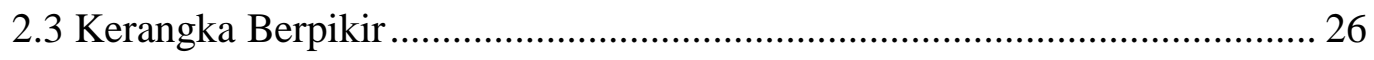

BAB III METODE PENELITIAN .................................................................. 28

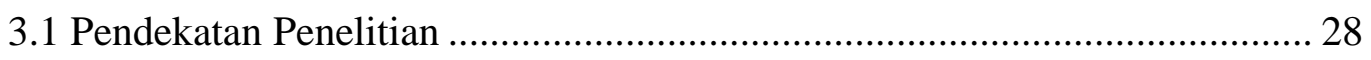

3.2 Lokasi dan Sasaran Penelitian............................................................... 29

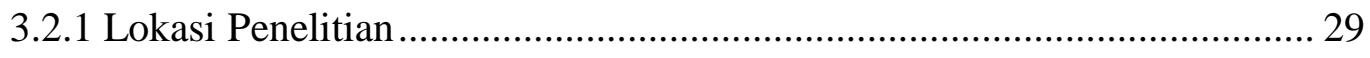

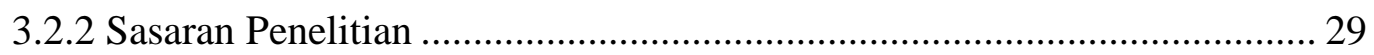

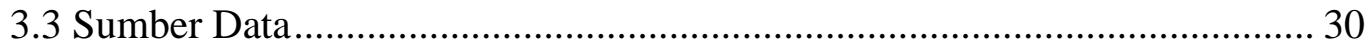




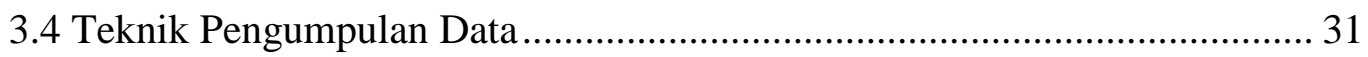

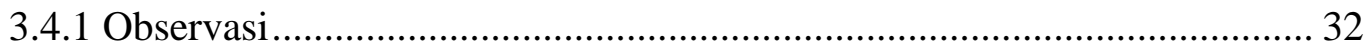

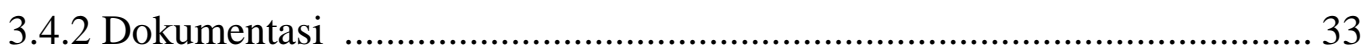

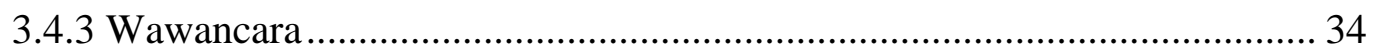

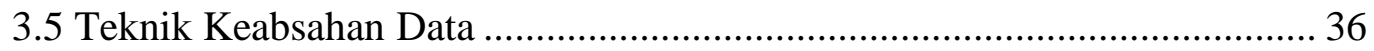

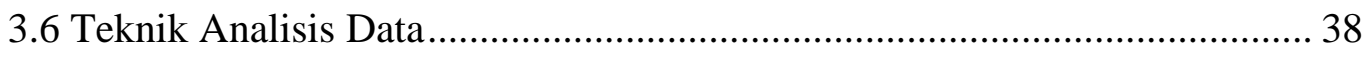

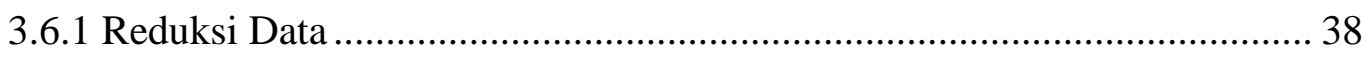

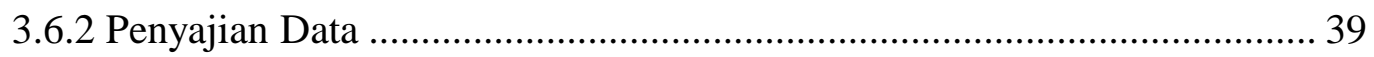

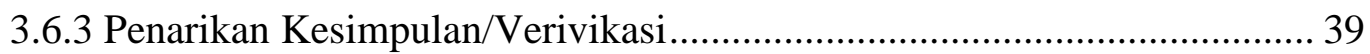

BAB IV HASIL PENELITIAN DAN PEMBAHASAN .............................. 41

4.1 Gambaran Umum Lokasi Penelitian ..................................................... 41

4.1.1 Kondisi dan Letak Geografis Desa Pasigitan, Kecamatan Boja,

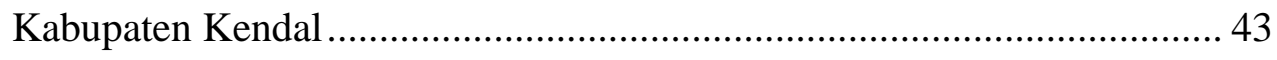

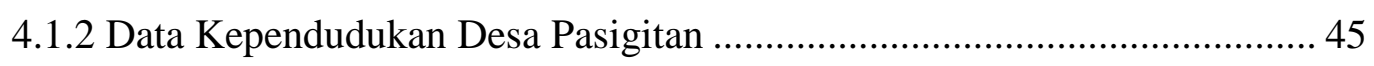

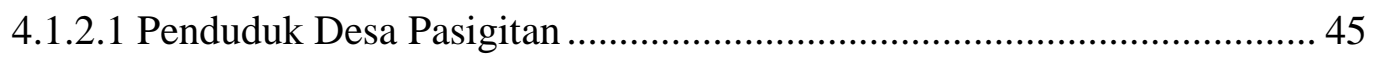

4.1.2.2 Mata Pencaharian Penduduk Desa Pasigitan ........................................ 46

4.1.2.3 Agama Penduduk Desa Pasigitan...................................................... 47

4.1.2.4 Pendidikan Penduduk Desa Pasigitan .................................................. 48

4.1.3 Kesenian di Desa Pasigitan ............................................................... 49

4.2 Latar Belakang Tari Opak Abang ........................................................ 49

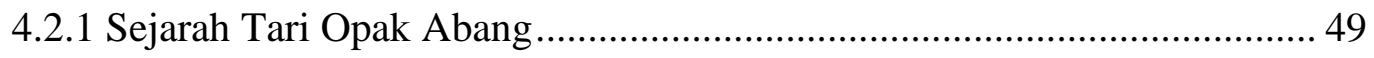

4.3 Bentuk Pertunjukan Tari Opak Abang .................................................... 54

4.3.1 Deskripsi Pertunjukan Tari Opak Abang ............................................... 54 
4.3.2 Struktur Pertunjukan Tari Opak Abang ................................................. 55

4.3.2.1 Awal Pertunjukan Tari Opak Abang .................................................... 55

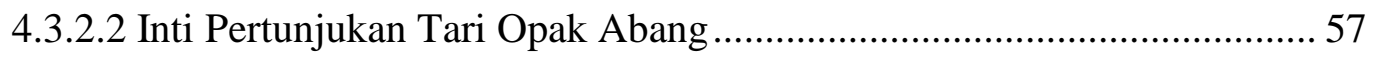

4.3.2.3 Akhir Pertunjukan Tari Opak Abang .................................................. 61

4.4 Komponen Pendukung Bentuk Pertunjukan Tari Opak Abang ................... 63

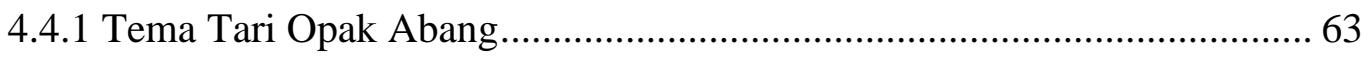

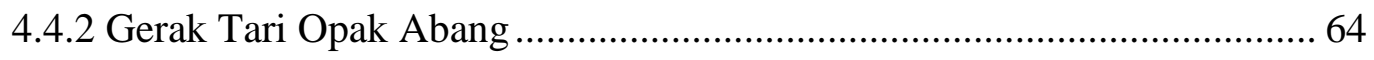

4.4.2.1 Ruang Gerak Tari Opak Abang........................................................... 74

4.4.2.1.1 Garis Gerak Tari Opak Abang .......................................................... 74

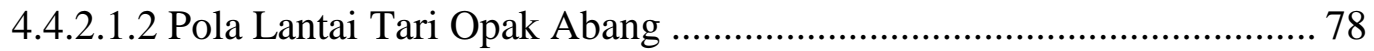

4.4.2.1.3 Volume Gerak Tari Opak Abang …................................................ 83

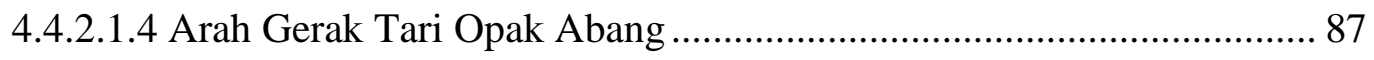

4.4.2.1.5 Level Gerak Tari Opak Abang ....................................................... 90

4.4.2.1.6 Fokus Pandang Gerak Tari Opak Abang ........................................... 93

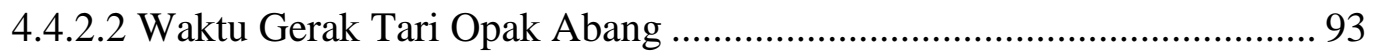

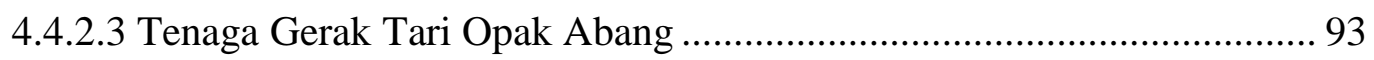

4.4.3 Tata Rias dan Busana Tari Opak Abang ................................................ 95

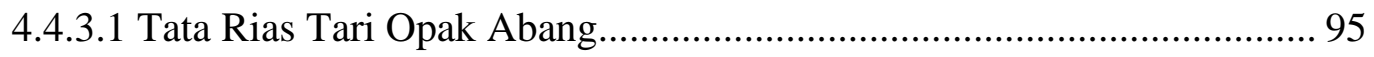

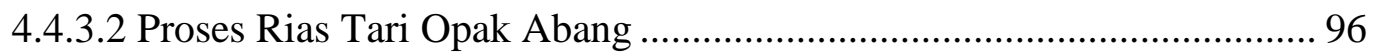

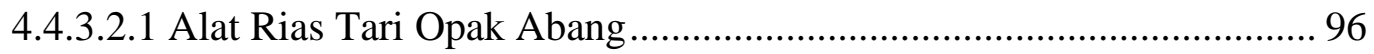

4.4.3.2.2 Langkah-Langkah Rias Tari Opak Abang ..................................... 98

4.4.3.2.2.1 Tata Rias Wajah Tari Opak Abang ............................................. 98

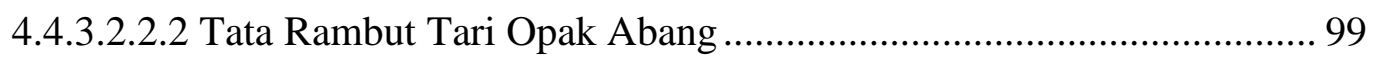


4.4.3.3 Tata Busana Tari Opak Abang ........................................................... 99

4.4.3.3.1 Plisir/Irah-irahan Tari Opak Abang ............................................... 101

4.4.3.3.2 Selempang Tari Opak Abang ..................................................... 102

4.4.3.3.3 Slepe/Sabuk Tari Opak Abang ............................................................ 103

4.4.3.3.4 Baju Lengan Panjang Tari Opak Abang ............................................. 104

4.4.3.3.5 Celana Panjang Tari Opak Abang.................................................... 105

4.4.3.3.6 Kaos Kaki Putih Tari Opak Abang .................................................. 106

4.4.3.3.7 Kain Songket Tari Opak Abang .................................................... 107

4.4.3.3.8 Sampur/Selendang Tari Opak Abang................................................. 108

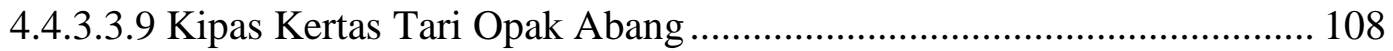

4.4.3.3.10 Kacamata Hitam Tari Opak Abang ................................................ 109

4.4.3.3.11 Kain Penutup Kepala Tari Opak Abang.......................................... 110

4.4.3.4 Proses Busana Tari Opak Abang..................................................... 111

4.4.4 Musik/Iringan Tari Opak Abang ....................................................... 112

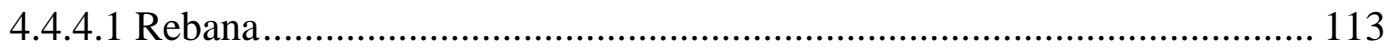

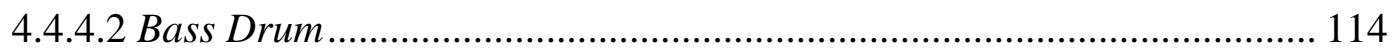

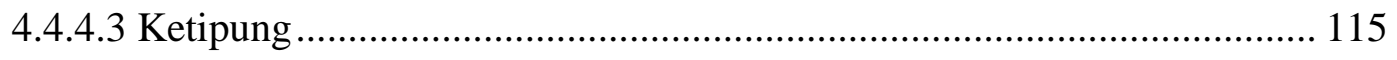

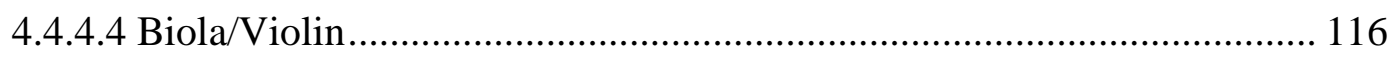

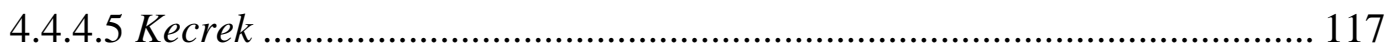

4.4.4.6 Notasi dan Syair Iringan Tari Opak Abang.......................................... 118

4.4.5 Tata Pentas Tari Opak Abang .......................................................... 122

4.4.6 Tata Lampu/Pencahayaan Tari Opak Abang ........................................ 123

4.4.7 Tata Suara Tari Opak Abang................................................................. 125 
4.4.8 Pelaku Tari Opak Abang ................................................................. 129

4.4.9 Penonton Pertunjukan Tari Opak Abang ….......................................... 130

4.5 Perubahan Fungsi Pertunjukan Tari Opak Abang....................................... 133

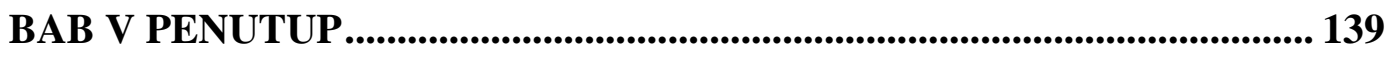

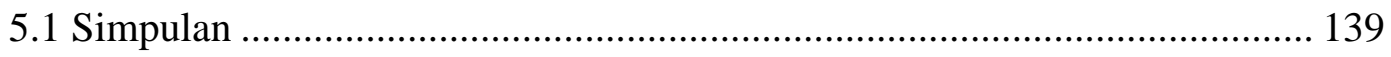

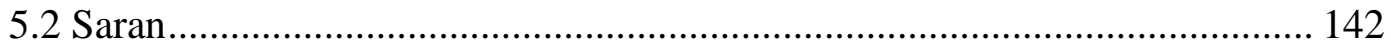

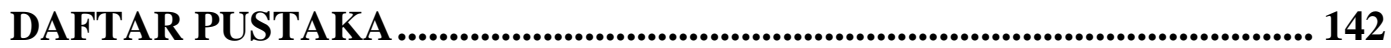

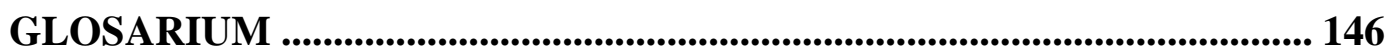

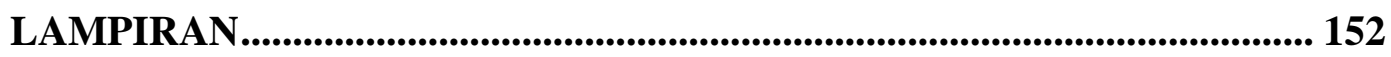




\section{DAFTAR TABEL}

Tabel

Halaman

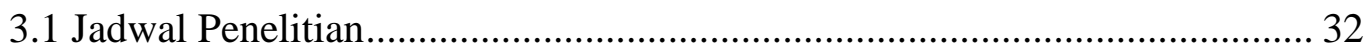

4.1 Jumlah Dusun/Dukuh, RW, dan RT di Kecamatan Boja............................ 42

4.2 Jumlah Dusun, RW, dan RT di Desa Pasigitan........................................ 43

4.3 Jumlah Penduduk Desa Pasigitan Berdasarkan Kelompok Umur dan Jenis

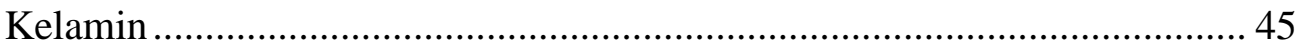

4.4 Mata Pencaharian Penduduk Desa Pasigitan .............................................. 46

4.5 Jumlah Pemeluk Agama di Desa Pasigitan ................................................ 47

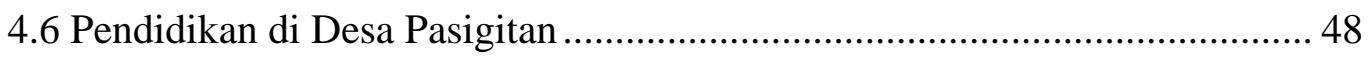

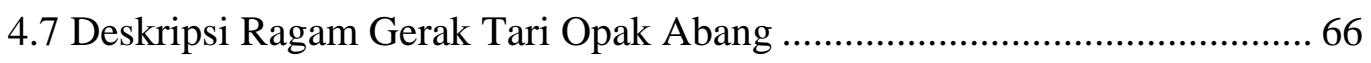




\section{DAFTAR BAGAN}

Bagan

Halaman

2.1 Kerangka Berpikir..

26

3.1 Komponen-Komponen Analisis Data: Model Interaktif...............................38 


\section{DAFTAR FOTO}

Foto

Halaman

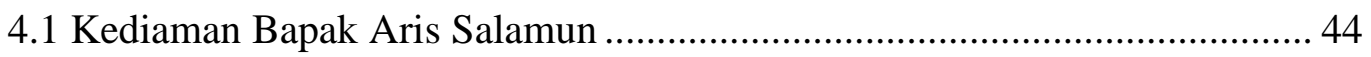

4.2 Sambutan Pembuka oleh Bapak Aris Salamun ........................................... 55

4.3 Penari dan Pemusik Bersiap-siap untuk Tampil ........................................ 56

4.4 Penari Opak Abang Memasuki Area Pertunjukan ...................................... 57

4.5 Bagian Pertama Tari Opak Abang: Gayung Seribu Gayung ....................... 58

4.6 Bagian Ke Dua Tari Opak Abang: Opak-Opak ......................................... 59

4.7 Bagian Ke Tiga Tari Opak Abang: Terang Bulan ........................................ 60

4.8 Bagian Ke Empat Tari Opak Abang: Bunga Rampai ................................. 61

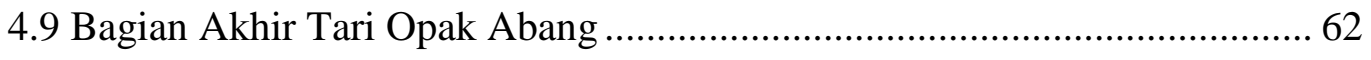

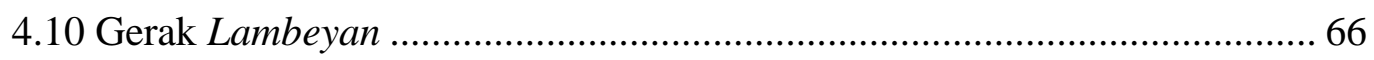

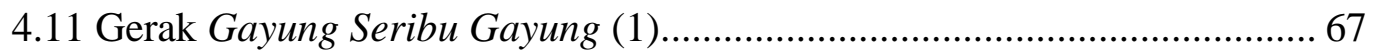

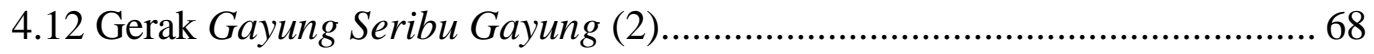

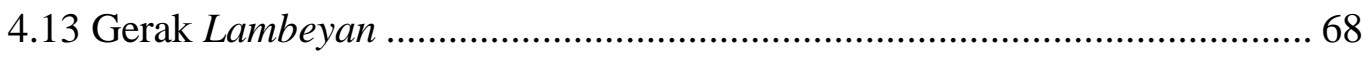

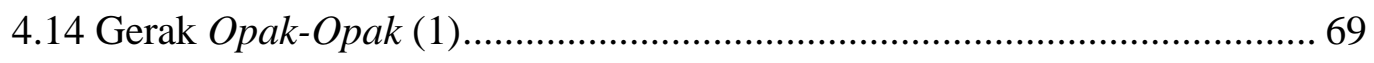

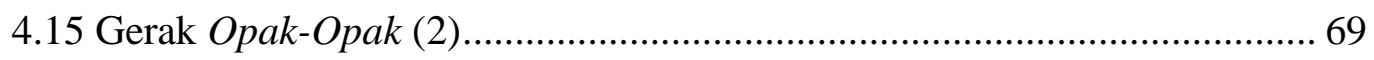

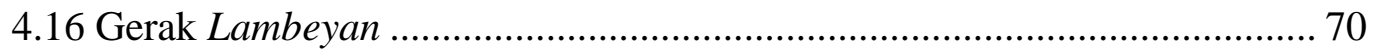

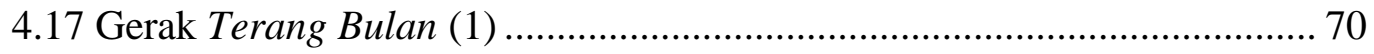

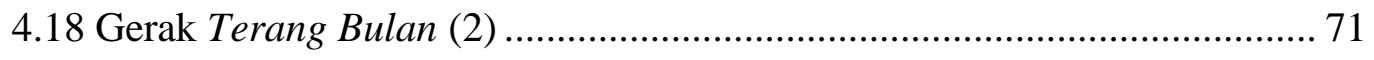

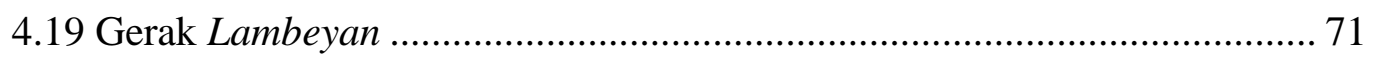

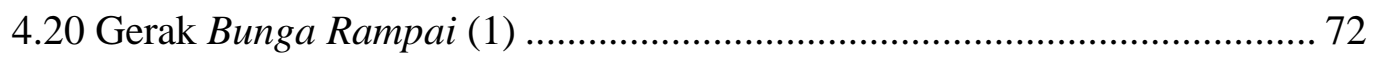

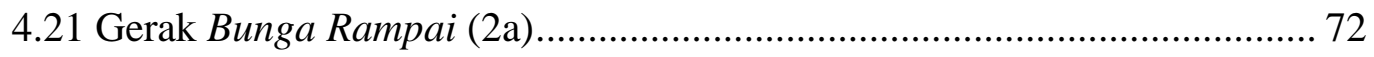




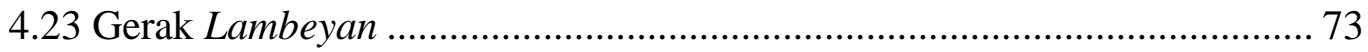

4.24 Garis Lengkung pada Gerak Tari Opak Abang ...................................... 75

4.25 Garis Lurus pada Gerak Tari Opak Abang ............................................. 76

4.26 Garis Menyilang pada Gerak Tari Opak Abang ...................................... 77

4.27 Formasi Sejajar pada Awal Tari Opak Abang ......................................... 78

4.28 Formasi Berbentuk Trapesium pada Bagian Gayung Seribu Gayung ........ 79

4.29 Formasi Diagonal pada Bagian Opak-Opak .......................................... 80

4.30 Formasi Berbentuk Trapesium pada Bagian Terang Bulan ....................... 81

4.31 Formasi Berbentuk Trapesium pada Bagian Bunga Rampai .................... 82

4.32 Formasi Sejajar pada Akhir Tari Opak Abang........................................ 83

4.33 Gerak Tari Opak Abang dengan Volume Kecil...................................... 84

4.34 Gerak Tari Opak Abang dengan Volume Sedang ................................... 85

4.35 Gerak Tari Opak Abang dengan Volume Besar ........................................ 86

4.36 Arah Gerak Tari Opak Abang ke Samping Kanan dan Samping Kiri ........ 87

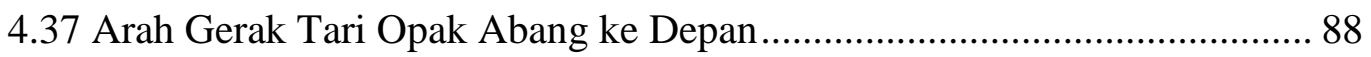

4.38 Arah Gerak Tari Opak Abang ke Belakang ........................................... 89

4.39 Arah Gerak Tari Opak Abang Serong ke Kiri Depan .............................. 90

4.40 Gerak Tari Opak Abang Level Rendah.................................................. 91

4.41 Gerak Tari Opak Abang Dominan Level Sedang ..................................... 92

4.42 Gerak Tari Opak Abang yang Menggunakan Intensitas Tenaga Lemah .... 94

4.43 Tata Rias Wajah Tari Opak Abang ...................................................... 95

4.44 Tata Busana Tari Opak Abang ................................................................. 100 


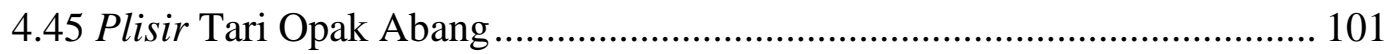

4.46 Selempang Tari Opak Abang ............................................................. 102

4.47 Slepe/Sabuk Tari Opak Abang ............................................................. 103

4.48 Baju Lengan Panjang Tari Opak Abang ................................................... 104

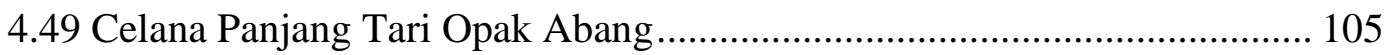

4.50 Kaos Kaki Putih Tari Opak Abang …................................................... 106

4.51 Kain Songket Tari Opak Abang .......................................................... 107

4.52 Sampur/Selendang Tari Opak Abang .................................................. 108

4.53 Kipas Kertas Tari Opak Abang ............................................................... 109

4.54 Kacamata Hitam Tari Opak Abang ......................................................... 109

4.55 Kain Penutup Kepala Tari Opak Abang................................................ 110

4.56 Proses Memakai Kostum Tari Opak Abang........................................... 111

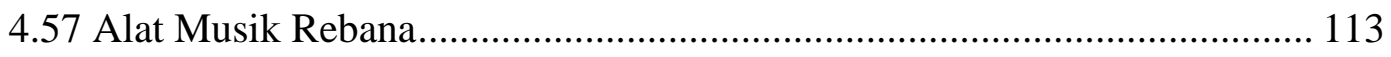

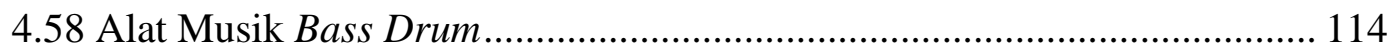

4.59 Alat Pemukul Bass Drum ................................................................. 115

4.60 Alat Musik Ketipung................................................................... 115

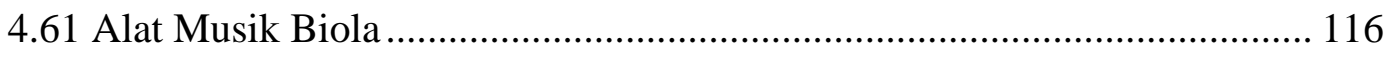

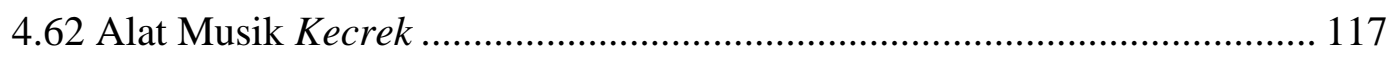

4.63 Area Pertunjukan Tari Opak Abang .................................................... 123

4.64 Lampu yang Digunakan Pada Pertunjukan Tari Opak Abang ................... 124

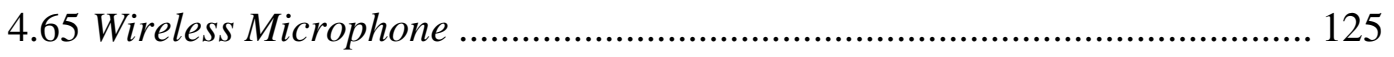

4.66 Sindhen Menggunakan Wireless Microphone ........................................ 126

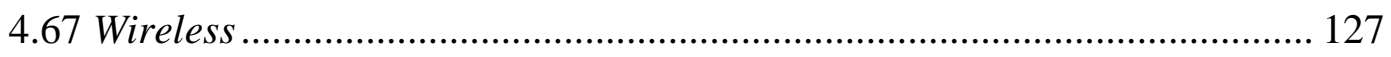


4.68 Keyboard Amplifier.

4.69 Pelaku Pertunjukan Tari Opak Abang...

4.70 Penonton Pertunjukan Tari Opak Abang 132 


\section{DAFTAR LAMPIRAN}

Lampiran

Halaman

1. Instrumen Penelitian Bentuk dan Fungsi Seni Pertunjukan Tari Opak Abang Desa Pasigitan Kecamatan Boja Kabupaten Kendal 152

2. Hasil Wawancara 155

3. Profil Narasumber 163

4. Foto 170

5. SK Dosen Pembimbing. 174

6. Surat Permohononan Izin Penelitian 175

7. Surat Keterangan Telah Melaksanakan Penelitian 176 


\section{BAB I \\ PENDAHULUAN}

\subsection{Latar Belakang}

Tari Opak Abang merupakan tari tradisional yang berasal dari Desa Pasigitan, Kecamatan Boja, Kabupaten Kendal. Tari Opak Abang lahir dari lingkungan rakyat, sehingga dapat disebut sebagai tari rakyat. Tari Opak Abang sebagai tari rakyat, memiliki gerak, iringan, tata rias, kostum dan pementasan yang sederhana. Perkembangan Tari Opak Abang di Desa Pasigitan termasuk lambat dari tahun 1956 hingga tahun 2017, hal ini dibuktikan dengan belum adanya variasi-variasi gerakan, musik, dan tata busana yang baru. Para pelaku pertunjukan Tari Opak Abang tetap mempertahankan orisinalitas Tari Opak Abang, akan tetapi zaman yang semakin maju membuat selera masyarakat berubah terhadap pertunjukan tari, sehingga berimbas pada turunnya kuantitas pementasan Tari Opak Abang.

Nama Tari Opak Abang berasal dari dua kata, yaitu Kethoprak dan Terbang. Terbang merupakan salah satu alat musik yang digunakan untuk mengiringi setiap penampilan Tari Opak Abang, atau lebih akrab disebut dengan rebana. Pada tahun 1957, Tari Opak Abang pertama kali dipentaskan sebagai sajian pembuka dari rangkaian pertunjukan kethoprak tradisional Kendal yang mengangkat cerita dari Babat Tanah Jawa atau cerita khas masyarakat Kecamatan Boja, yaitu kisah Nyai Dapu (Wawancara: Aris Salamun, 2 Oktober 2015). Masyarakat sering menyebut kethoprak dan terbang menjadi Opak Abang, sejak itu, tarian pembuka dari kethoprak yang iringan musiknya menggunakan terbang, dikenal sebagai Tari Opak Abang. 
Tari Opak Abang awalnya merupakan bagian dari sebuah pertunjukan kethoprak, sehingga pementasan Tari Opak Abang tidak pernah lepas dari pertunjukan kethoprak. Zaman yang semakin berkembang dan durasi yang terbatas untuk pementasan membuat Tari Opak Abang akhirnya tidak lagi dipentaskan untuk pembukaan kethoprak, akan tetapi pementasan Tari Opak Abang berdiri sendiri. Tari Opak Abang ketika pementasannya bersama dengan kethoprak, memiliki durasi yang lama, bahkan bisa semalam suntuk untuk keseluruhan pertunjukan. Pementasan Tari Opak Abang untuk menghemat waktu, pertunjukannya tidak lagi dilanjutkan dengan kethoprak, melainkan hanya tarian saja selama kurang lebih 12 menit (Wawancara: Aris Salamun, 22 Januari 2017). Masyarakat merasa diuntungkan ketika mementaskan Tari Opak Abang tanpa disertai dengan kethoprak karena meminimalisir jumlah personil yang tampil dan waktu yang digunakan untuk pertunjukan sedikit, sehingga dinilai lebih praktis dan ekonomis oleh masyarakat setempat.

Tari Opak Abang oleh masyarakat Desa Pasigitan biasa ditampilkan sebagai sajian hiburan dalam acara-acara desa seperti hajatan, maupun tirakatan Hari Ulang Tahun Kemerdekaan Republik Indonesia setiap tanggal 17 Agustus. Grup kesenian yang sampai saat ini tetap mempertahankan keberadaan Tari Opak Abang yaitu Sri Langen Budaya Bumi dengan ketua Bapak Aris Salamun. Grup Sri Langen Budaya Bumi telah diakui secara resmi oleh Dinas Pendidikan dan Kebudayaan Provinsi Jawa Tengah pada 30 Oktober 1997 sebagai grup kesenian yang berasal dari Desa Pasigitan, Kecamatan Boja, Kabupaten Kendal. 
Tari Opak Abang berbeda dengan tarian lain karena mempunyai keunikankeunikan terletak pada gerak tariannya yang sangat sederhana dengan banyak pengulangan dan tempo gerak yang stabil. Kesederhanaan yang terdapat pada gerak Tari Opak Abang mempunyai nilai keunikan tersendiri, sehingga penampilan Tari Opak Abang tidak membosankan dan dapat dipelajari dengan mudah oleh seluruh lapisan masyarakat. Tari Opak Abang juga memiliki perlengkapan busana yang unik. Keunikan perlengkapan busana terletak pada pemakaian kacamata hitam, kaos kaki berwarna putih dan aksesoris sebanyak dua buah kipas kecil terbuat dari kertas berwarna emas yang diletakkan di telinga kanan dan kiri. Keunikan lainnya juga tampak pada iringan Tari Opak Abang. Iringan Tari Opak Abang menggunakan alat-alat musik yang sedikit, karena hanya menggunakan 3 buah terbang atau rebana, 1 buah bass drum, 1 buah ketipung satu sisi, 1 buah kecrek dan 1 buah biola. Tari Opak Abang diiringi musik yang syairnya berisi tentang nasihat moral dan agama. Syair berisi nasihat moral dan agama merupakan ciri khas Tari Opak Abang selain dari gerak, dan tata busana.

Pertunjukan Tari Opak Abang sebagai tari rakyat yang berkembang di Desa Pasigitan pernah dipentaskan dalam ritual sedekah bumi pada tahun 1995 di Kabupaten Kendal. Tari Opak Abang tidak hanya dipentaskan di daerahnya saja, melainkan pernah ditampilkan di panggung Taman Mini Indonesia Indah, dan juga sempat mengikuti festival tari rakyat di beberapa kota, akan tetapi seiring berjalannya waktu, beberapa fungsi pertunjukan Tari Opak Abang mengalami perubahan karena perkembangan zaman dan selera masyarakat yang berubah. Berdasarkan latar belakang mengenai bentuk dan fungsi seni pertunjukan Tari 
Opak Abang yang telah disebutkan, mendorong peneliti untuk mengetahui bentuk dan perubahan fungsi seni pertunjukan Tari Opak Abang di Desa Pasigitan Kecamatan Boja Kabupaten Kendal.

\subsection{Rumusan Masalah}

Berdasarkan uraian di atas, permasalahan yang dikaji dalam penelitian ini adalah :

1. Bagaimana bentuk pertunjukan Tari Opak Abang di Desa Pasigitan Kecamatan Boja Kabupaten Kendal?

2. Bagaimana perubahan fungsi yang terjadi pada pertunjukan Tari Opak Abang di Desa Pasigitan Kecamatan Boja Kabupaten Kendal dalam kurun waktu tahun 1956 sampai tahun $2017 ?$

\subsection{Tujuan Penelitian}

Sebagaimana rumusan-rumusan masalah yang telah disebutkan, tujuan dilakukannya penelitian ini yaitu untuk mengetahui dan mendeskripsikan bagaimana bentuk pertunjukan Tari Opak Abang dan bagaimana perubahan fungsi yang terjadi pada pertunjukan Tari Opak Abang di Desa Pasigitan Kecamatan Boja Kabupaten Kendal dalam kurun waktu tahun 1956 sampai tahun 2017. 


\subsection{Manfaat Penelitian}

Peneliti berharap agar penelitian yang berjudul Bentuk dan Fungsi Seni Pertunjukan Tari Opak Abang Desa Pasigitan Kecamatan Boja Kabupaten Kendal dapat memberikan manfaat sebagai berikut:

\subsubsection{Manfaat teoritis}

1. Hasil penelitian dapat menjadi sarana penambah informasi mengenai bentuk dan perubahan fungsi yang terjadi pada pertunjukan Tari Opak Abang bagi dinas pariwisata dan kebudayaan serta departemen terkait lainnya, sehingga menambah wawasan mengenai kekayaan budaya yang dimiliki oleh Kabupaten Kendal.

2. Hasil penelitian dapat dijadikan sebagai acuan, dan rujukan untuk penelitianpenelitian berikutnya.

\subsubsection{Manfaat praktis}

1. Bagi seniman, hasil penelitian dapat digunakan sebagai sarana penambah informasi mengenai Tari Opak Abang, sehingga secara tidak langsung telah membantu mempertahankan keberadaan Tari Opak Abang. Seniman dari Kendal juga dapat terus menghidupkan kesenian tradisional daerahnya khususnya Tari Opak Abang.

2. Bagi grup Sri Langen Budaya Bumi, hasil penelitian dapat membantu untuk tetap mempertahankan keberadaan Tari Opak Abang, dan sebagai promosi Tari Opak Abang kepada masyarakat.

3. Bagi penari Opak Abang, hasil penelitian dapat dijadikan sebagai penyemangat untuk terus mempertahankan keberadaan Tari Opak Abang. 
4. Bagi masyarakat, hasil penelitian dapat dijadikan sebagai sarana penambah informasi tentang Tari Opak Abang.

5. Bagi peneliti, hasil penelitian dapat digunakan sebagai sarana penambah informasi secara mendetil mengenai bentuk dan perbuahan fungsi yang terjadi pada seni pertunjukan Tari Opak Abang.

\subsection{Sistematika Penulisan}

Sistematika penulisan dibuat untuk mempermudah pemahaman tentang garis besar dari isi skripsi ini, yang berisi sebagai berikut:

I. Bagian awal skripsi:

Sampul, Halaman Judul, Persetujuan Pembimbing, Motto dan Persembahan, Sari, Prakata, Daftar Isi, Daftar Gambar, Daftar Tabel, dan Daftar Lampiran

II. Bagian isi skripsi :

BAB I Pendahuluan

Berisi Latar Belakang Masalah, Rumusan Masalah, Tujuan Penelitian, Manfaat Penelitian, dan Sistematika Penulisan.

BAB II Tinjauan Pustaka dan Landasan Teoritis

Berisi Tinjauan Pustaka, Landasan Teoretis dan Kerangka Berpikir.

BAB III Metode Penelitian

Berisi Pendekatan Penelitian, Lokasi Dan Sasaran Penelitian, Sumber Data, Teknik Pengumpulan Data, Teknik Keabsahan Data dan Teknik Analisis Data. Bab ini menguraikan tentang metode penelitian beserta elemen-elemen pendukung penelitian yang digunakan dalam penelitian ini. 
BAB IV Hasil Penelitian dan Pembahasan

Berisi tentang Gambaran Umum Lokasi Penelitian, Latar Belakang Tari Opak Abang, Bentuk Pertunjukan Tari Opak Abang, Komponen Pendukung Seni Pertunjukan, dan Perubahan Fungsi Pertunjukan Tari Opak Abang.

BAB V Penutup

Berisi Simpulan dan Saran mengenai bentuk dan fungsi Tari Opak Abang di Desa Pasigitan, Kecamatan Boja, Kabupaten Kendal.

III. Bagian akhir skripsi:

Berisi Daftar Pustaka, dan Lampiran berupa gambar-gambar yang diambil ketika sedang melakukan penelitian, data narasumber, serta data prestasi yang pernah dicapai oleh Tari Opak Abang di Desa Pasigitan. 


\section{BAB II \\ TINJAUAN PUSTAKA DAN LANDASAN TEORETIS}

\subsection{Tinjauan Pustaka}

Tinjauan pustaka dalam penelitian berfungsi sebagai sumber acuan atau referensi dalam melakukan suatu penelitian agar peneliti mendapatkan wawasan serta informasi yang relevan guna mendukung hasil penelitian. Tinjauan pustaka dapat mempermudah peneliti dalam mendeskripsikan hasil penelitian mengenai bentuk dan fungsi seni pertunjukan Tari Opak Abang. Peneliti telah meninjau penelitian-penelitian terdahulu yang terkait dengan penelitian mengenai Bentuk dan Fungsi Seni Pertunjukan Tari Opak Abang Desa Pasigitan Kecamatan Boja Kabupaten Kendal, sehingga peneliti dapat menentukan sudut pandang penelitian yang berbeda dalam memulai penelitian. Penelitian-penelitian terdahulu yang dikaji peneliti sebelum melakukan penelitian baru, antara lain:

Pertama, artikel yang dimuat dalam Jurnal Seni Tari Volume 1 Nomor 1 tahun 2012 dengan judul Eksistensi Tari Opak Abang sebagai Tari Daerah Kabupaten Kendal oleh Sellyana Pradewi dan Wahyu Lestari (2012). Persamaan yang ada pada artikel dengan penelitian ini adalah objek penelitiannya yaitu Tari Opak Abang, dan metode yang digunakan yakni metode kualitatif. Perbedaan penelitian terletak pada pokok bahasan, karena artikel yang berjudul Eksistensi Tari Opak Abang sebagai Tari Daerah Kabupaten Kendal mengkaji tentang eksistensi atau keberadaan Tari Opak Abang sebagai kesenian tradisional Kabupaten Kendal tanpa disertai dengan uraian mengenai tata urutan pertunjukan dan fungsi pertunjukan. 
Ke dua, penelitian mengenai Analisis Komposisi Musik Iringan Kesenian Opak Abang di Kabupaten Kendal oleh Rezali Canggih Sukma (2013). Objek yang dikaji masih sama, yaitu kesenian Opak Abang, dan dengan menggunakan metode yang sama yakni metode pendekatan kualitatif. Fokus penelitian untuk Analisis Komposisi Musik Iringan Kesenian Opak Abang di Kabupaten Kendal adalah terletak di komposisi musik Tari Opak Abang, sehingga terdapat perbedaan yang jelas pada cara penjabaran hasil penelitian.

Ke tiga, tesis yang berjudul Bentuk dan Fungsi Pertunjukan Jathilan dalam Upacara Ritual Kirab Pusaka pada Masyarakat Kampung Tidar Warung Kelurahan Tidar Magelang oleh Cicilia Ika Rahayu Nita (2005). Perbedaan yang dimiliki dengan penelitian ini terletak pada objek penelitiannya serta gambaran umum tentang bentuk dan fungsi pertunjukan Jathilan tanpa disertai dengan deskripsi ragam gerak dan notasi iringan.

Ke empat, artikel Trisakti (2013) yang dimuat dalam Prosiding The $5^{\text {th }}$ International Conference on Indonesian Studies: "Ethnicity and Globalization" dengan judul Bentuk dan Fungsi Seni Pertunjukan Jaranan dalam Budaya Masyarakat Jawa Timur. Artikel penelitian ini membahas tentang bentuk, struktur dan urutan penyajian Tari Jaranan yang ada di Jawa Timur. Perbedaan antara artikel Trisakti dengan penelitian ini terletak pada objek penelitian dan bagaimana Trisakti menjabarkan pertunjukan Tari Jaranan menjadi beberapa adegan, sedangkan peneliti Tari Opak Abang menguraikan pertunjukan secara mendetil pada deskripsi ragam gerak, tata rias dan busana serta notasi iringannya yang dilengkapi dengan syair. 
Penelitian relevan ke lima, artikel yang dibuat oleh Nurul Amalia dan Bintang Hanggoro Putra (2015) dalam Jurnal Seni Tari Volume 4 nomor 2 dengan judul Bentuk dan Fungsi Kesenian Tradisional Krangkeng di Desa Asemdoyong Kecamatan Taman Kabupaten Pemalang. Kesenian tradisional Krangkeng merupakan kesenian rakyat yang lahir di Desa Asemdoyong, Pemalang. Krangkeng memiliki keunikan di dalam pertunjukannya karena menggunakan gerakan pencak silat atau bela diri beserta atraksi-atraksi lainnya. Penelitian mengenai kesenian Krangkeng memiliki perbedaan dengan penelitian tentang Tari Opak Abang karena pada kesenian Krangkeng merupakan sebuah kesatuan pertunjukan atraksi yang disertai tarian dan dibagi menjadi beberapa babak pertunjukan.

Ke enam, artikel dengan judul Bentuk dan Fungsi Pertunjukan Tari Mayang Rontek Kabupaten Mojokerto dalam Gelar Seni Budaya Daerah Jawa Timur di Taman Budaya Surabaya oleh Ayuk Dhamar Sapitri (2016) dalam APRON Jurnal Pemikiran Seni Pertunjukan Volume 2 Nomor 10. Artikel mengenai Tari Mayang Rongtek memiliki hubungan dengan penelitian ini karena sama-sama membahas tentang bentuk dan fungsi pertunjukan tari. Perbedaan yang terdapat dengan penelitian ini yaitu pada penelitian Tari Mayang Rontek meneliti dari prespektif festival atau gelar karya pertunjukan tari, sedangkan penelitian ini menguraikan Tari Opak Abang sebagai tari tradisional yang ada di lingkungan rakyat.

Penelitian relevan yang ke tujuh tentang Bentuk Pertunjukan Kuda Kepang Indang Purwosari di Desa Cindaga Kecamatan Kebasen Kabupaten Banyumas oleh Prastiti Ade Kusumaningrum (2016). Penelitian Prastiti menjabarkan tentang 
bentuk pertunjukan Kuda Kepang Indang Purwosari ditinjau dari beberapa elemen-elemen pertunjukan yang sama dengan penelitian ini, yaitu: 1) pelaku; 2) gerak tari; 3) tata rias dan busana; 4) musik; 5) tempat pementasan; 6) tata suara; 7) penonton, akan tetapi ada beberapa elemen yang berbeda antara penelitian Prastiti dengan penelitian ini yaitu terletak pada elemen sesaji dan properti. Penelitian ini tidak menggunakan elemen sesaji dan properti, karena Tari Opak Abang tidak menggunakan sesaji dan properti pada setiap pertunjukannya. Perbedaan lainnya antara penelitian Prastiti dengan penelitian ini yakni pembahasan mengenai fungsi pertunjukan yang tidak disertakan pada penelitian mengenai Kuda Kepang, sedangkan penelitian ini turut menyertakan pembahasan mengenai fungsi pertunjukan Tari Opak Abang.

Penelitian ke delapan, Bentuk Pertunjukan Ebeg "Teater Janur" di Kecamatan Purwokerto Selatan Kabupaten Banyumas oleh Tugiatiningsih (2013). Penelitian Tugiatiningsih memiliki kesamaan dengan penelitian ini karena mengambil objek penelitian kesenian rakyat. Elemen-elemen bentuk pertunjukan pada penelitian Tugiatiningsih memiliki beberapa persamaan dari segi pelaku, gerak, iringan, tema, tata busana, tata rias, tata panggung, tata lampu, tata suara dan penonton, selain itu fungsi pertunjukan juga dibahas pada penelitian Tugiatiningsih dan penelitian ini. Elemen bentuk pertunjukan yang berbeda antara penelitian Tugiatiningsih dan penelitian ini yaitu properti. Penelitian mengenai Tari Opak Abang tidak menggunakan properti dalam pertunjukannya. Penelitian Tugiatiningsih menjabarkan bentuk pertunjukan Ebeg Teater Janur menjadi beberapa adegan, antara lain: 1) pra acara: persiapan pertunjukan; 2) pembukaan: 
jogedan; 3) inti pertunjukan: janturan dan laesan; 4) akhir pertunjukan: mendem bersama, sedangkan penelitian Tari Opak Abang menjabarkan bentuk pertunjukan dalam bentuk deskripsi ragam gerak dengan urutan: 1) gayung seribu gayung; 2) opak-opak; 3) terang bulan; 4) bunga rampai.

Penelitian berikutnya yang mempunyai relevansi dengan penelitian ini yaitu Bentuk dan Fungsi Pertunjukan Tari Kuntulan Ulul Albab di Desa Dukuh Anggrung Kecamatan Sirampog Kabupaten Brebes oleh Nala Zumrotul Kamila (2016). Penelitian Nala Zumrotul Kamila mengemukakan tentang Tari Kuntulan Ulul Albab yang ditinjau dari bentuk dan fungsi pertunjukan. Persamaan penelitian Nala dengan penelitian ini yaitu sama-sama membahas tentang bentuk dan fungsi pertunjukan tari. Perbedaan penelitian Nala dengan penelitian ini yaitu objek penelitiannya, serta pembahasan yang terdapat di dalam penelitian karena penelitian tentang Tari Kuntulan menggunakan aspek-aspek komposisi dalam menjabarkan bentuk pertunjukan Tari Kuntulan Ulul Albab seperti aspek visual yang meliputi: gerak; ruang; level; fokus pandangan; waktu; tempo; ritme; durasi; dinamika; dan pemain, lalu aspek penyajian yang meliputi: tata panggung; rias dan busana; porperti dan tata suara; tata lampu; dan formasi, sedangkan penelitian ini menjabarkan bagaimana bentuk Tari Opak Abang berdasarkan unsur-unsur pendukung pertunjukan tari, seperti: tema; gerak; iringan; tata rias busana; tata pentas; tata lampu; tata suara; pelaku; dan penonton.

Penelitian-penelitian terdahulu yang relevan dengan penelitian Bentuk dan Fungsi Seni Pertunjukan Tari Opak Abang Desa Pasigitan Kecamatan Boja Kabupaten Kendal membuktikan bahwa belum ada satu penelitian yang 
membahas tentang bentuk dan fungsi pertunjukan Tari Opak Abang, namun ada beberapa hasil penelitian yang dapat dirujuk untuk kepentingan penelitian bentuk dan fungsi seni pertunjukan Tari Opak Abang.

\subsection{Landasan Teoretis}

Landasan teoretis merupakan teori-teori yang digunakan sebagai landasan penelitian. Landasan teoretis mencakup teori-teori dan konsep-konsep yang digunakan sebagai landasan kerja penelitian. Teori-teori yang digunakan dalam landasan teoretis harus dipertanggungjawabkan melalui kajian sejumlah pustaka yang memuat hasil penelitian dalam lingkup topik penelitian yang menggunakan teori terpilih maupun yang menggunakan topik berbeda (Syaifudin dkk 2014:9).

\subsubsection{Bentuk Seni Pertunjukan}

Murgiyanto (1992:36) mengatakan "Bentuk" merupakan segalanya yang terkait dengan pengaturan. Pada tari, bentuk merupakan sebuah hal yang teramati dan berupa gerakan yang dilakukan oleh fisik. Hoppu (2014:312) menjelaskan bahwa fenomena seni pertunjukan muncul dalam berbagai bentuk yang khas, dan studi tentang hubungan antara pertunjukan sosial dan budaya selalu mengambil konteks budaya yang menjadi penyebabnya.

Bentuk seni pertunjukan tari dan musik memiliki urut-urutan penyajian, yang merupakan bagian dari keseluruhan pementasannya. Ada bagian awal atau pembukaan, yang kemudian dilanjutkan dengan bagian utama, selanjutnya bagian akhir pertunjukan yang masih dalam satu rangkaian pementasan. Pada setiap urutan penyajian dapat diamati waktu yang dibutuhkan oleh masing-masing urutan penyajian (Susetyo 2007:9). 
Seni pertunjukan tradisional merupakan seni yang hidup dan berkembang dalam suatu daerah atas dasar kesepakatan bersama yang dilakukan antara masyarakat pendukungnya. Seni pertunjukan tradisional dilaksanakan secara turun temurun dari generasi ke generasi dalam masyarakat pendukungnya. Seni pertunjukan tradisional pada umumnya memiliki ciri khas yang tetap pada bentuk seninya (Susetyo 2007:11).

Seni pertunjukan memiliki beberapa jenis yaitu seni musik, seni teater, dan seni tari. Utina dan Wahyu Lestari (2006:14) menjelaskan bahwa seni pertunjukan tari meliputi tari rakyat, sendratari, dramatari, langendriyan, langen mandrawanara, langen kusuma dan bentuk tari. Bentuk seni pertunjukan tari sebagai karya seniman, terlahir sebagai ungkapan lewat unsur-unsur seperti tema, gerak, iringan/musik, tata rias dan busana, tata pentas, tata lampu/pencahayaan, tata suara, pelaku, dan penonton. Kerterkaitan yang erat antar unsur-unsur pendukung pertunjukan tari akan menimbulkan sebuah pementasan yang kompleks.

\subsubsection{Tari}

Tari menurut Royce (2007:2) yaitu sebuah seni yang paling tua dan pada tari terdapat gerak-gerak ritmis yang mempunyai maksud tertentu. Teori Royce didukung oleh Sulastuti (2006:11) yang menjabarkan bahwa tari merupakan salah satu cabang seni yang tidak menggunakan komunikasi verbal melainkan menggunakan gerak sebagai 'bahasa' dalam berkomunikasi.

Pada tari dikenal tiga istilah yang mendasari keindahan dalam seni tari, antara lain wiraga yang berarti keselarasan gerakan dari anggota tubuh, wirama berarti 
keselarasan dengan irama atau musik iringan, dan wirasa yang mempunyai maksud penjiwaan melalui ekspresi terhadap isi dan tema tarian. Tiga istilah dalam tari yakni wiraga, wirama, dan wirasa saling terkait satu sama lain sehingga menghasilkan sebuah tarian yang kompleks (Hartono 2012: 68).

Jazuli (1994:70) mengemukakan bahwa tari berdasarkan pola garapannya dapat dibagi menjadi dua, yaitu tari tradisional dan tari kreasi. Soedarsono (1977:29) menyebutkan bahwa tari tradisional yaitu jenis-jenis tarian yang telah mengalami perjalanan sejarah yang cukup lama, dan yang selalu bertumpu pada pola-pola tradisi yang sudah ada. Tari tradisional untuk lebih spesifik dapat dibagi berdasarkan atas nilai-nilai artistiknya, yaitu tari rakyat dan tari klasik. Hoerburger (1968:30) menjelaskan bahwa pada tarian rakyat tertentu memiliki tingkat kepercayaan atau keyakinan agama dalam tariannya, dan pada umumnya penciptaan tarian rakyat bertujuan untuk sarana rekreasi dan hiburan.

\subsubsection{Unsur-unsur Pendukung Pertunjukan Tari}

Tari merupakan salah satu dari berbagai jenis seni pertunjukan. Tari sebagai seni pertunjukan memiliki unsur-unsur sebagai pelengkap sajian tari, di antaranya: 1) iringan/musik, 2) tema, 3) tata busana, 4) tata rias, 5) tempat/pentas, 6) tata cahaya/lampu, dan 7) tata suara (Jazuli 2008:13). Teori pelengkap sajian tari oleh Jazuli diperkuat dengan adanya gerak, pelaku dan penonton sebagai hal yang pokok dalam sebuah pertunjukan tari. Tari akan menjadi sebuah seni pertunjukan yang utuh apabila didukung oleh unsur-unsur sebagai berikut. 


\subsection{Tema}

Humphrey (1983:44) menyebutkan bahwa tema berasal dari pengalaman yang dialami oleh penata tari lalu dicermati dan disesuaikan lebih lanjut agar dapat diungkapkan secara tepat dalam bentuk gerak. Jazuli (2008:18-19) mengemukakan beberapa hal yang dapat dijadikan sebagai sumber tema, antara lain: 1) Pengalaman hidup pribadi seseorang dengan segala peristiwa yang dialami, seperti kesenangan, kekecewaan, kesombongan, ketamakan, dan sebagainya; 2) Kehidupan binatang dengan sifat dan perangainya; 3) Kejadian sehari-hari di sekitar kita atau lingkungan masyarakat seperti kejahatan, keresahan, dan sebagainya; 3) Cerita-cerita rakyat atau legenda suatu wilayah seperti Sangkuriang, Legenda Banyuwangi dan Timun Mas; 4) Sejarah dari seorang tokoh tertentu, seperti Gajah Mada, RA. Kartini, Sunan Kalijaga, dan sebagainya; 5) Karya sastra, seperti epos Ramayana, dan Mahabarata; 6) Upacaraupacara tradisional, seperti upacara keagamaan dan upacara adat, 7) Pemahaman dari seni lainnya, seperti drama, musik, sastra, dan sebagainya.

\subsection{Gerak}

Widyastutiningrum dan Dwi Wahyudiarto (2014: 36) menyebutkan gerak dalam tari merupakan gerak yang dihasilkan dari tubuh manusia sebagai unsur yang utama dari sebuah karya tari. Teori mengenai gerak oleh Jazuli (1994:5) yaitu gerak tari merupakan hasil dari proses pengolahan seperti stilasi (digayakan) dan distorsi (pengubahan), yang kemudian melahirkan dua jenis gerak, yaitu gerak murni dan gerak maknawi. Gerak murni (pure movement) disebut gerak wantah yakni gerak yang disusun dengan tujuan untuk mendapatkan bentuk artistik 
(keindahan) dan di dalam geraknya tidak mempunyai maksud-maksud tertentu. Gerak maknawi (gesture) atau gerak tidak wantah merupakan gerak yang mengandung arti atau maksud tertentu dan telah distilasi (dari wantah menjadi tidak wantah).

Penari perlu menguasai hal-hal dasar dalam tari yaitu wiraga, wirama, dan wirasa. Sasmintamardawa (Rahayu 2015:17-18) menjelaskan bahwa pentingnya penari untuk menguasai wiraga, wirama, dan wirasa dalam tari. Wiraga merupakan kemampuan penari dalam mengolah tubuhnya yang didukung oleh kelenturan penguasaan teknik tenaga, dan penguasaan ruang serta ungkapan gerak yang jelas dan bersih. Hal ini berlaku untuk semua penari tanpa memandang pria atau wanita, karena kelenturan tubuh merupakan daya tarik yang pertama kali terlihat saat sebuah karya tari disajikan. Gerak yang indah dihasilkan oleh tubuh dengan tingkat kelenturan atau keluwesan yang baik. Wirama, merupakan kemampuan penari dalam ketepatan tempo, ritme, dan irama. Penari yang baik yaitu penari yang dapat menyesuaikan antara gerak yang dilakukan dengan irama. Penari dituntut untuk dapat mengendalikan ritme dan tempo agar dapat selaras dengan gerak. Wirasa, dapat disebut sebagai penguasaan rasa atau kemampuan penari dalam mengekspresikan tari yang dibawakannya. Penghayatan penari sangat dibutuhkan ketika sedang menampilkan sebuah sajian tari. Penari hendaknya dapat menyatukan antara jiwa dan tubuhnya agara tercipta keseimbangan dan kesinambungan yang luluh dari berbagai unsur dan elemen tari.

Murgiyanto (1983:22) menyebutkan bahwa gerak mempunyai tiga buah aspek, yaitu: 1) ruang; 2) waktu; dan 3) tenaga. Ruang merupakan sesuatu yang 
berkaitan dengan pernyataan setting dan penggunaan tempat dalam pentas (MD Slamet dalam Rahayu 2015:25). Pendapat lainnya mengenai ruang dikemukakan oleh Murgiyanto (1983:23) bahwa seorang penari hendaknya mampu mengontrol penggunaan ruang sehingga dapat memperbesar kekuatan gerak yang dilakukan oleh penari karena gerak penari berinteraksi dengan ruang. Ruang memiliki aspekaspek pendukung di dalamnya. antara lain: 1) garis: serangkaian gerakan yang dilakukan oleh penari sehingga dapat memberikan kesan berbagai macam garis, seperti garis lengkung, garis lurus, dan garis menyilang; 2) volume: besar kecilnya ukuran gerak yang dilakukan oleh penari; 3) arah: gerak yang dilakukan ke arah depan, belakang, samping kanan, samping kiri, serong kiri, dan serong kanan; 4) level: tingkatan dalam gerak memiliki ketinggian yang berbeda, seperti rendah, tinggi, dan sedang; 5) fokus pandang: arah pandangan yang ditimbulkan pada saat penari sedang berada di atas pentas; 6) pola lantai: bentuk-bentuk yang dihasilkan oleh formasi penari kelompok yaitu segitiga, lingkaran, huruf $\mathrm{V}$, dan sebagainya (Murgiyanto 1983:23-25; Widyastutieningrum 2014:46).

Waktu merupakan salah satu elemen gerak tari yang mencakup cepat-lambat, kontras, berkesinambungan, dan rasa berlalunya waktu sehingga dapat dipergunakan secara efektif (Murgiyanto 1983:25). Pada waktu, terdapat elemenelemen pendukung di dalamnya, antara lain: 1) tempo: kecepatan yang berasal dari gerakan tubuh; 2) meter: ketukan dalam gerakan yang dilakukan oleh penari; 3) ritme: keteraturan gerak penari yang saling berkesinambungan (Murgiyanto 1983:26, Humphrey 1983:122). 
Tenaga dalam gerak tari dibutuhkan penari agar dapat melakukan gerakan halus, lincah, atau bahkan gerakan yang berat. Tenaga memiliki faktor-faktor pendukung di dalamnya, antara lain: 1) intensitas: banyak sedikitnya tenaga yang dikeluarkan penari ketika bergerak; 2) tekanan/aksen: apabila ada penggunaan tenaga yang tidak merata saat bergerak, digunakan untuk membedakan antara pola gerak yang satu dengan pola gerak lainnya; 3) kualitas: cara untuk menggunakan dan menyalurkan tenaga ketika bergerak (Murgiyanto 1983:28).

\subsection{Iringan/Musik}

Jazuli (2008:14) menelaah tentang fungsi musik, antara lain: 1) sebagai pengiring tari, 2) sebagai pemberi suasana, 3) sebagai ilustrasi tari. Sebagai pengiring tari berarti peranan musik hanya untuk mengiringi atau menunjang penampilan tari, sehingga tak banyak ikut berandil dalam isi tarinya. Namun demikian, musik tetap merupakan bagian yang tak terpisahkan dari tari. Sebagai pemberi suasana biasanya digunakan pada pertunjukan dramatari. Pada fungsi ini, musik digunakan untuk mewujudkan suasana-suasana tertentu seperti suasana agung, suasana sedih, gembira, tenang, bingung, suasana gaduh, dan sebagainya. Sebagai ilustrasi tari dapat dijelaskan bahwa musik diperlukan hanya pada bagianbagian tertentu dari keseluruhan sajian tari, bisa hanya berupa pengantar sebelum tari disajikan, bisa hanya bagian depan dari keseluruhan tari, atau hanya bagian tengah dari keseluruhan sajian tari (Jazuli 1994:10-12).

\subsection{Tata Rias dan Busana}

Tata rias wajah merupakan penggunaan bahan-bahan kosmetika untuk mewujudkan suatu peranan agar dapat mudah dipresepsikan oleh penonton. Pada 
tata rias wajah, teradpat dua hal yang harus diperhatikan dalam tata rias wajah untuk keperluan pentas yaitu lighting (tata lampu atau pencahayaan) dan jarak antara pemain dan penonton (Harymawan dalam Sumarni 2001:39).

Rias busana merupakan segala tindakan untuk memperindah diri agar kelihatan menarik. Busana merupakan segala sesuatu yang dipakai mulai dari rambut sampai kaki. Busana yang baik hendaknya memiliki bagian-bagian yang saling melengkapi satu sama lain sehingga menjadi kesatuan penampilan busana yang utuh (Lestari 1993:16).

Fungsi busana tari yaitu untuk mendukung tema atau isi tari, dan untuk memperjelas peran-peran dalam suatu sajian tari. Busana tari yang baik bukan hanya sekedar untuk menutupi tubuh semata, melainkan juga harus dapat mendukung desain ruang pada saat penari sedang menari. Oleh karena itu, di dalam penataan dan penggunaan busana tari hendaknya senantiasa mempertimbangkan hal-hal sebagai berikut: 1) Penggunaan busana hendaknya sopan dan sedap dipandang oleh penonton; 2) Penggunaan busana mempunyai keterkaitan dengan isi atau tema tari sehingga terdapat hubungan antara tari dengan tata busananya; 3) Penataan busana dapat menstimulasi daya imajinasi penonton yang melihatnya; 4) Pemakaian busana tidak mengganggu kenyamanan dan tidak menghambat gerak penari; 5) Busana hendaknya dapat menjadi bagian dari diri penari ketika sedang dikenakan pada saat pertunjukan; 6) Pemilihan warna-warna busana baiknya mempertimbangkan efek yang dihasilkan ketika disorot dengan cahaya (Jazuli 2008:20-21). 


\subsection{Tata Pentas}

Jazuli (2008:25) mengemukakan bahwa setiap pertunjukan memiliki tempat yang digunakan untuk mementaskan atau mempergelarkan pertunjukan itu sendiri. Tempat pementasan suatu pertunjukan tentu berbeda-beda disesuaikan dengan tujuan atau kepentingan pertunjukan yang dipentaskan. Bentuk-bentuk tempat pertunjukan dibagi menjadi tiga, antara lain: 1) arena terbuka, seperti lapangan dan halaman yang luas; 2) pendapa, yaitu suatu bangunan yang berbentuk joglo dan berpilar pokok empat, tanpa penutup pada sisi-sisinya; 3) pemanggungan (staging), digunakan untuk mempergelarkan atau mementaskan tarian yang dipertontonkan.

\subsection{Tata Lampu/Pencahayaan}

Pencahayaan merupakan salah satu unsur yang penting dalam berlangsungnya sebuah pertunjukan. Pencahayaan selain untuk menerangi pertunjukan, digunakan untuk pemberi suasana dalam sebuah pertunjukan. Tata lampu atau pencahayaan merupakan pengaturan cahaya yang disesuaikan dengan keadaan yang akan digambarkan di atas panggung (Prasetya 2010:34-36).

Jazuli (2008:29) menjelaskan bahwa sebuah penataan lampu dapat dikatakan berhasil apabila dapat memberikan kontribusi-kontribusi pada objek yang ada di atas panggung sehingga terlihat hidup dan mendukung sajian tari. Tata lampu dalam pertunjukan tari dapat memperjelas penyampaian maksud sajian tari. Penggunaan lighting dapat memberi gambaran yang pas terkait suasana, latar tempat dalam sebuah pertunjukan tari. 


\subsection{Tata Suara}

Jazuli (2008: 29) mengemukakan kehadiran pengeras suara dalam suatu pementasan mutlak dibutuhkan untuk menarik perhatian orang-orang yang berada jauh dari arena agar datang menyaksikan pementasan. Pengeras suara selain untuk menarik penonton juga untuk penari itu sendiri, agar dapat mendengar dengan jelas iringan dan lagu yang mengiringi pementasannya sehingga memperlancar jalannya pementasan.

Teori Jazuli mengenai tata suara diperkuat oleh Pekerti (2008:539) yang menyatakan bahwa tata suara merupakan penataan seperangkat alat sumber bunyi untuk tujuan mengatur musik untuk iringan tari. Tata suara akan memperjelas suara atau bunyi musik iringan tari dengan demikian pertujukan tari tersebut menjadi lebih hidup. Tinggi dan rendahnya kualitas tata suara akan mempengaruhi isi dan jalannya sebuah pertunjukan tari.

\subsection{Pelaku}

Cahyono (2006:64-65) menjelaskan dalam seni pertunjukan memiliki pelaku yang berbeda-beda, ada pelaku pertunjukan yang anak-anak, remaja, dan dewasa. Jumlah pelaku yang melaksanakan seni pertunjukan juga bervariasi. Seni pertunjukan tertentu menggunakan jumlah pelaku tunggal atau berpasangan bahkan dengan jumlah pelaku yang besar atau kelompok. Pelaku tunggal yaitu pelaku sebuah seni pertunjukan yang tampil seorang diri, pelaku berpasangan berarti dua orang yang menampilkan sebuah seni pertunjukan, sedangkan pelaku kelompok merupakan pelaku sebuah seni pertunjukan yang berjumlah lebih dari dua orang. 


\subsection{Penonton}

Seni pertunjukan terdiri dari tiga unsur utama yaitu sang seniman, karya seni, dan penonton. Pada seni pertunjukan, penonton memiliki peranan yang mutlak dan penting di dalamnya. Pertunjukan membutuhkan kehadiran penonton sebagai jembatan dialog yang disampaikan oleh seniman melalui karya seni yang sedang dipentaskan. Keberadaan penonton bisa melengkapi suatu jalinan yang berujung pada nilai pembelajaran dan nilai kebersamaan dalam membangun konstruksi seni pertunjukan. Bangunan berupa pertunjukan membuktikan adanya kolaborasi antara tontonan dengan penonton atau masyarakat (Martono 2012:87).

Pada suatu pertunjukan, khususnya pertunjukan tari terdapat bentuk dan fungsi yang berada di dalamnya. Bentuk pertunjukan Tari Opak Abang dapat diidentifikasi berdasarkan unsur-unsur pendukung tari yang telah disebutkan sebelumnya dalam bab ini, antara lain: 1) tema; 2) gerak; 3) musik/iringan; 4) tata rias dan busana; 5) tata pentas; 6) tata lampu; 7) tata suara; 8) pelaku; 9) penonton. Kesatuan antara unsur-unsur pendukung tari sangat dibutuhkan dalam pertunjukan karena apabila salah satu unsur hilang atau sengaja dihilangkan, maka pertunjukan tari tidak utuh.

\subsubsection{Fungsi Seni Pertunjukan}

Ratih (2001:69) mengemukakan fungsi tari pada pokoknya dapat digolongkan menjadi empat bagian yaitu tari sebagai sarana upacara, hiburan, seni pertunjukan dan sebagai media pendidikan. Tari sebagai sarana upacara berarti tarian yang ditampilkan dalam upacara-upacara adat guna menambahkan kesakralan dan 
menghadirkan daya magis. Tari yang berfungsi sebagai sarana hiburan yaitu sekedar untuk menyalurkan hobi/kesenangan, mengembangkan keterampilan, atau tujuan-tujuan yang kurang menekankan nilai seni (komersial). Misalnya untuk perlengkapan suatu pesta atau perayaan-perayaan hari besar dan ulang tahun. Tari sebagai seni pertunjukan merupakan tari yang penyajiannya selalu mempertimbangkan nilai-nilai artistik, sehingga pengamat dapat memperoleh pengalaman estetis dari hasil pengamatannya. Tari sebagai media pendidikan mempunyai nilai-nilai pendidikan tari melalui tema-tema yang digunakan, sikapsikap gerak yang ada di dalamnya, dan sebagainya (Jazuli 1994:43-61).

Soekanto (2014:257-259) mengemukakan bahwa setiap masyarakat manusia selama hidup pasti mengalami perubahan-perubahan. Perubahan-perubahan masyarakat dapat mengenai nilai-nilai sosial, norma-norma sosial, pola-pola perilaku organisasi, susunan lembaga kemasyarakatan, interaksi sosial, dan lain sebagainya. Perubahan-perubahan yang terjadi pada masyarakat merupakan suatu hal yang normal karena adanya penemuan-penemuan baru di bidang teknologi yang terjadi di suatu tempat dengan cepat dapat diketahui oleh masyarakat lain yang berada jauh dari tempat tersebut. Kingsley Davis dalam Soekanto (2014:264) menjelaskan bahwa perubahan sosial merupakan bagian dari perubahan kebudayaan. Perubahan kebudayaan mencakup semua bagiannya, yaitu: kesenian, ilmu pengetahuan, teknologi, filsafat dan sebagainya.

Soekanto (2014:281-283) menjelaskan bahwa salah satu proses dalam perubahan yaitu difusi. Difusi merupakan proses penyebaran unsur-unsur kebudayaan dari individu ke individu lain, dan dari satu masyarakat ke 
masyarakat lain, sehingga manusia dapat manghimpun penemuan-penemuan baru. Soekanto (2014:273-280) menyebutkan faktor-faktor yang menyebabkan perubahan sosial dan kebudayaan menjadi 2, yaitu faktor intern (berasal dari dalam masyarakat itu sendiri) dan faktor ekstern (berasal dari luar masyarakat itu sendiri. Faktor intern penyebab perubahan sosial dan kebudayaan, yaitu: 1) bertambah atau berkurangnya penduduk; 2) penemuan-penemuan baru; 3) pertentangan-pertentangan masyarakat; dan 4) terjadinya pemberontakan atau revolusi di dalam tubuh masyarakat. Faktor ekstern penyebab perubahan sosial dan, yaitu: 1) lingkungan fisik di sekitar manusia; 2) peperangan dengan negara lain; dan 3) pengaruh kebudayaan masyarakat lain.

Berdasarkan penelitian, perubahan fungsi seni pertunjukan Tari Opak Abang di Desa Pasigitan melalui proses difusi, karena proses difusi menurut Horton dan Hunt (1984:215) disertai dengan modifikasi tertentu terhadap unsur-unsur budaya, sehingga pada fungsi dapat mengalami perubahan. Fungsi pertunjukan Tari Opak Abang di Desa Pasigitan berdasarkan hasil penelitian di lapangan yaitu sebagai sarana hiburan. Fungsi-fungsi pertunjukan tari sebagai sarana upacara, dan sarana pertunjukan tidak lagi ada dalam Tari Opak Abang karena perubahan yang terjadi dalam masyarakat disebabkan faktor intern, yaitu: penemuan-penemuan baru, dan faktor ekstern, yaitu: pengaruh kebudayaan masyarakat lain. 


\subsection{Kerangka Berpikir}

Bagan 2.1. Kerangka Berpikir

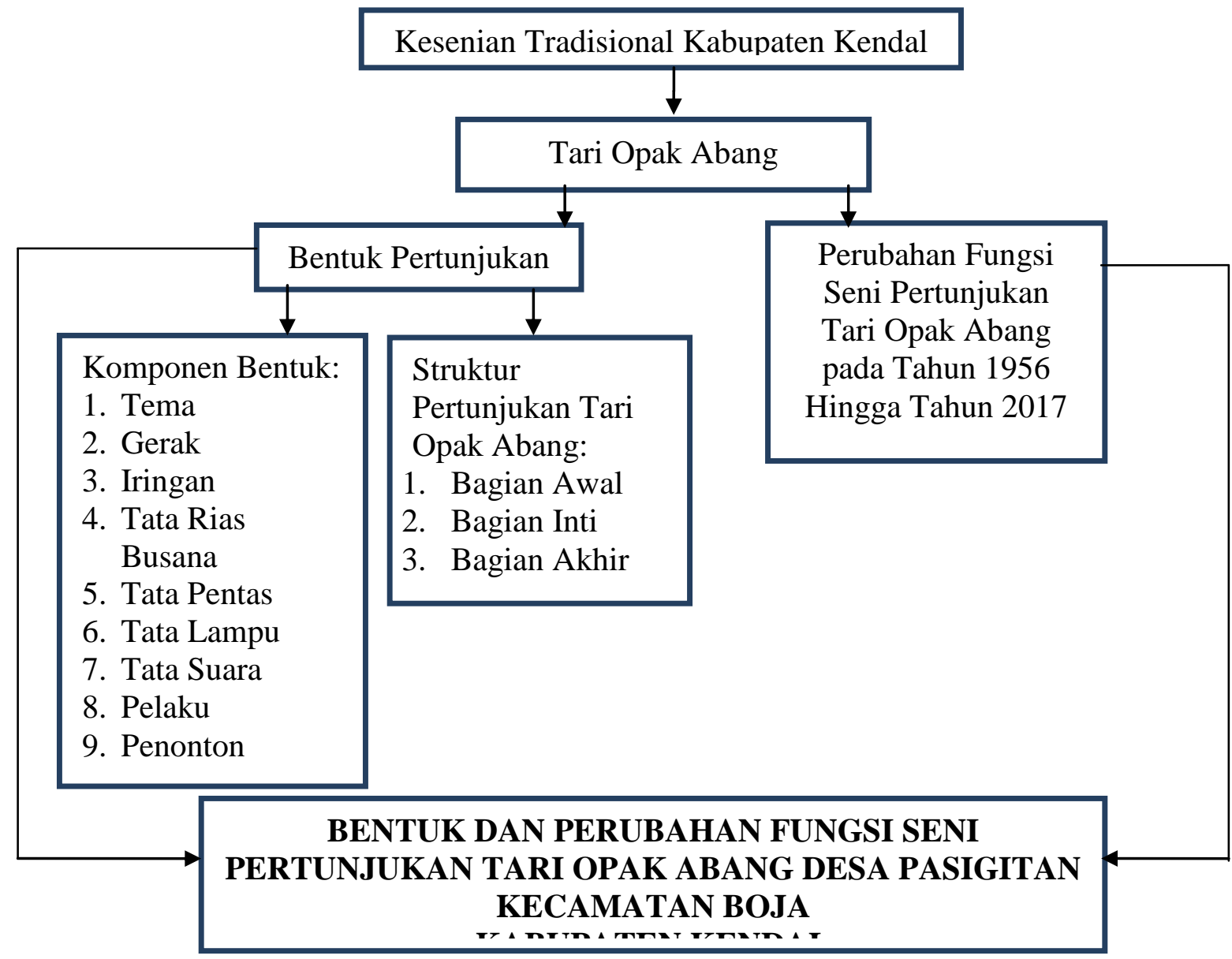

(Sumber: Frihastyayu Bintyar Mawasti, Juli 2016)

Keterangan:

Berdasarkan bagan 2.1. pokok bahasan utama dalam penelitian ini ialah Tari Opak Abang yang diteliti dari sudut bentuk dan fungsi pertunjukannya. Adapun yang menjadi komponen bentuk seni pertunjukan Tari Opak Abang, antara lain: tema, gerak, iringan, tata rias busana, tata pentas, tata lampu, tata suara, pelaku dan penonton pertunjukan. Tari Opak Abang memiliki urutan atau struktur penyajian, yaitu: bagian awal, bagian inti, dan bagian akhir. Pertunjukan Tari 
Opak Abang mempunyai berbagai fungsi, yakni: sebagai sarana hiburan, sebagai media pertunjukan, dan sebagai sarana upacara, akan tetapi seiring berjalannya waktu, fungsi-fungsi pertunjukan Tari Opak Abang mengalami perubahan. Keseluruhan aspek-aspek tersebut disatukan sehingga menciptaan sebuah keutuhan dalam "Bentuk dan Perubahan Fungsi Seni Pertunjukan Tari Opak Abang Desa Pasigitan Kecamatan Boja Kabupaten Kendal.” 


\section{BAB III \\ METODE PENELITIAN}

\subsection{Pendekatan Penelitian}

Pendekatan dalam konteks penelitian menurut Ibrahim (2015: 49) yaitu upaya atau tindakan yang disiapkan dan dilakukan untuk memulai proses penelitian serta dapat membantu memudahkan peneliti dalam menjalankan proses penelitian. Penelitian mengenai bentuk dan fungsi seni pertunjukan Tari Opak Abang menggunakan pendekatan penelitian kualitatif, sebagaimana Ibrahim (2015: 52) menjelaskan bahwa pendekatan kualitatif adalah cara kerja penelitian yang mengandalkan uraian deskriptif kata, atau kalimat, yang disusun secara cermat dan sistematis mulai dari mengumpulkan data, menafsirkan dan melaporkan hasil penelitian. Peneliti menggunakan pendekatan penelitian kualitatif dalam mengumpulkan data tentang bentuk dan fungsi pertunjukan Tari Opak Abang, selanjutnya peneliti melakukan penafsiran terhadap data-data yang telah dikumpulkan dan melaporkannya dalam bentuk uraian deskriptif kata.

Metode dalam penelitian merupakan cara-cara yang digunakan dalam melakukan sebuah penelitian (Ibrahim 2015: 50). Ragam metode dalam penelitian menurut Ibrahim (2015: 58) yaitu: deskriptif; eksperimen; eksploratif; dan eksplanatif. Metode yang digunakan peneliti untuk penelitian mengenai bentuk dan fungsi pertunjukan Tari Opak Abang adalah deksriptif, karena penelitian dengan metode deskriptif menurut Ibrahim (2015: 59) merupakan penelitian yang dimaksudkan untuk melukiskan, menggambarkan, atau memaparkan keadaan objek yang diteliti apa adanya, sesuai dengan keadaan di lapangan, maka peneliti 
memaparkan bentuk dan fungsi pertunjukan Tari Opak Abang apa adanya serta sesuai dengan keadaan di Desa Pasigitan.

Peneliti menguraikan bagaimana bentuk dan fungsi seni pertunjukan Tari Opak Abang di Desa Pasigitan, Kecamatan Boja, Kabupaten Kendal secara rinci berdasarkan komponen atau unsur-unsur seni pertunjukan, struktur penyajian dan fungsi-fungsi seni pertunjukan Tari Opak Abang sebagaimana telah dijelaskan pada bagan kerangka berpikir. Rumusan masalah yang dikaji pada penelitian yaitu mengenai bentuk dan fungsi seni pertunjukan Tari Opak Abang, sebagaimana hasil penelitian bentuk dan fungsi seni pertunjukan Tari Opak Abang di Desa Pasigitan, Kecamatan Boja, Kabupaten Kendal dilaporkan secara alamiah, sesuai dengan keadaan di lapangan dan penjabaran hasil penelitiannya tidak manipulatif.

\subsection{Lokasi Dan Sasaran Penelitian}

\subsubsection{Lokasi Penelitian}

Penelitian dilakukan di Desa Pasigitan, Kecamatan Boja, Kabupaten Kendal karena merupakan tempat berada Tari Opak Abang. Tari Opak Abang yang masih asli dapat ditemui di Desa Pasigitan, Kecamatan Boja, Kabupaten Kendal tepatnya di rumah Bapak Aris Salamun karena merupakan tempat berkumpulnya para pelaku pertunjukan Tari Opak Abang.

\subsubsection{Sasaran Penelitian}

Sasaran penelitian pada penelitian ini yaitu Tari Opak Abang. Penelitian difokuskan bentuk dan fungsi seni pertunjukan Tari Opak Abang di Desa Pasigitan Kecamatan Boja Kabupaten Kendal, karena Tari Opak Abang sebagai tari rakyat yang berkembang di Desa Pasigitan memiliki bentuk dan fungsi 
pertunjukan yang berbeda dengan tarian rakyat yang lain. Bentuk pertunjukan Tari Opak Abang dapat ditinjau dari beberapa aspek, antara lain: 1) tema; 2) gerak; 3) iringan; 4) tata rias busana; 5) tata pentas; 6) tata lampu/pencahayaan; 7) tata suara; 8) pelaku; dan 9) penonton.

\subsection{Sumber Data}

Sumber data adalah orang, benda, atau objek yang dapat memberikan data, informasi, fakta dan realitas yang relevan dengan apa yang sedang diteliti (Ibrahim 2015: 67). Klasifikasi sumber data menurut Lofland dan Lofland (dalam Ibrahim 2015: 69) yaitu sumber data utama dan tambahan.

Sumber data utama (primer) yakni kata-kata atau tindakan orang yang berkedudukan sebagai penentu data/informasi bagi suatu penelitian atau orang yang terlibat secara langsung dengan apa yang sedang diteliti (Ibrahim 2015: 70). Pada penelitian tentang bentuk dan fungsi pertunjukan Tari Opak Abang, yang menjadi sumber data utama (primer) yakni perkataan dan tindakan dari para pelaku dan para penonton pertunjukan Tari Opak Abang di Desa Pasigitan.

Sumber data tambahan (sekunder) adalah segala bentuk dokumen, baik dalam bentuk tertulis maupun foto (Ibrahim 2015: 70). Sumber data tambahan (sekunder) pada penelitian tentang bentuk dan fungsi pertunjukan Tari Opak Abang yakni berupa foto-foto piagam penghargaan Tari Opak Abang, notasi serta syair iringan Tari Opak Abang yang diperoleh dari partisipan, dan dokumendokumen kependudukan Desa Pasigitan yang diperoleh dari Bappeda Kabupaten Kendal. 
Data dan sumber data dalam sebuah penelitian adalah satu paket, karena data tidak mungkin dipisahkan dengan sumber data. Data dalam penelitian berarti segala bentuk informasi, fakta dan realita yang relevan dengan apa yang sedang diteliti. Data dalam penelitian diklasifikasi menjadi primer dan sekunder (Ibrahim 2015: 67-68).

Data primer menurut Ibrahim (2015: 68) adalah segala informasi, fakta, dan realitas yang terkait secara langsung dengan penelitian. Bungin (dalam Ibrahim 2015: 68) menyebutkan bahwa data primer didapat dari sumber primer atau sumber pertama di lapangan. Data primer penelitian mengenai bentuk dan fungsi pertunjukan Tari Opak Abang diperoleh dari para pelaku dan para penonton pertunjukan Tari Opak Abang di Desa Pasigitan.

Data sekunder menurut Ibrahim (2015: 68) adalah segala informasi, fakta, dan realitas yang terkait dengan penelitian, akan tetapi tidak secara langsung. Data sekunder turut membantu semakin lengkap dan jelasnya hasil penelitian. Data sekunder dalam penelitian tentang bentuk dan fungsi pertunjukan Tari Opak Abang berupa data statistik Desa Pasigitan, dan biodata para narasumber penelitian.

\subsection{Teknik Pengumpulan Data}

Teknik pengumpulan data menurut Ibrahim (2015: 79) yang digunakan dalam penelitian bentuk dan fungsi seni pertunjukan Tari Opak Abang ada berbagai jenis, antara lain: observasi; dokumentasi; dan wawancara. 


\subsubsection{Observasi}

Observasi adalah metode pengamatan dan pencatatan secara sistematik terhadap unsur-unsur yang nampak pada objek penelitian. Unsur-unsur yang dimaksud adalah data atau informasi yang harus diamati dan dicatat secara benar dan lengkap. Metode observasi digunakan agar peneliti memperoleh gambaran yang lebih luas tentang permasalahan yang diteliti di lapangan (Widoyoko 2012: 46). Observasi mengenai bentuk dan fungsi pertunjukan Tari Opak Abang dilakukan dalam kurun waktu 2 bulan, dimulai dari bulan Januari 2017 lalu selanjutnya bulan April 2017 yang disajikan ke dalam tabel 3.1.

Tabel 3.1 Jadwal Penelitian

\begin{tabular}{|c|l|c|c|c|c|c|c|c|c|}
\hline \multirow{2}{*}{ No } & \multicolumn{1}{|c|}{ Jenis Kegiatan } & \multicolumn{3}{|c|}{ Januari } & \multicolumn{4}{c|}{ April } \\
\cline { 2 - 9 } 2 & 1 & 2 & 3 & 4 & 1 & 2 & 3 & 4 \\
\hline 1 & $\begin{array}{l}\text { Wawancara dengan pelaku seni } \\
\text { Tari Opak Abang } \\
\text { Wawancara dengan penonton } \\
\text { pertunjukan Tari Opak Abang } \\
\text { Dokumentasi pertunjukan, tata } \\
\text { busana dan alat-alat musik Tari } \\
\text { Opak Abang }\end{array}$ & & & $\sqrt{ }$ & $\sqrt{ }$ & & & $\sqrt{ }$ & \\
\end{tabular}

(Sumber: Mawasti 28 Februari 2017)

Berdasarkan tabel 3.1, peneliti memulai observasi pada tanggal 22 Januari 2017 di kediaman Bapak Aris Salamun, Dusun Siranti, Desa Pasigitan, Kecamatan Boja, Kabupaten Kendal dengan membawa handphone untuk merekam suara Bapak Aris Salamun dan Ibu Pujiati, buku catatan kecil dan ballpoint untuk mencatat informasi, serta melengkapi informasi dengan membawa blangko biodata narasumber. Observasi yang ke dua, pada tanggal 30 Januari 2017, peneliti menuju kediaman Bapak Aris Salamun dengan membawa 
handphone dan buku catatan kecil untuk mendokumentasi alat-alat musik Tari Opak Abang. Observasi ke tiga, pada tanggal 21 April 2017, peneliti mengamati dan mendokumentasi proses latihan di kediaman Bapak Aris Salamun yang dilakukan oleh grup Sri Langen Budaya Bumi untuk pertunjukan tanggal 22 April 2017 dengan menggunakan kamera handphone, selain itu peneliti juga mengamati dan mendokumentasi perlengkapan busana Tari Opak Abang. Observasi yang terakhir, pada tanggal 22 April 2017, peneliti mewawancarai dan mendokumentasi para pelaku pertunjukan Tari Opak Abang serta melengkapi informasi dengan membawa blangko biodata narasumber, kemudian peneliti mendokumentasi dengan kamera handphone dan mengamati jalannya pertunjukan Tari Opak Abang di depan kediaman Bapak Aris Salamun, peneliti juga mengamati, mendokumentasi dan mewawancara penonton yang menyaksikan pertunjukan Tari Opak Abang dengan menggunakan kamera handphone, buku catatan dan ballpoint.

\subsubsection{Dokumentasi}

Dokumentasi menurut Arikunto (2010: 274) adalah mencari data mengenai hal-hal yang berupa catatan, transkrip, foto dan sebagainya yang terkait dengan objek penelitian. Dokumentasi yang diperoleh peneliti dari narasumber utama, Bapak Aris Salamun, yaitu: foto-foto piagam penghargaan yang telah diraih oleh Tari Opak Abang, didapat pada tanggal 14 Januari 2016; foto piagam pengesahan grup Sri Langen Budaya Bumi, didapat pada tanggal 14 Januari 2016; dan syair iringan Tari Opak Abang, didapat pada tanggal 14 Januari 2016. Dokumentasi yang diperoleh peneliti dari narasumber kedua, yaitu: data terkait kondisi 
geografis Kecamatan Boja dan Desa Pasigitan yang didapat dari Bappeda Kabupaten Kendal tahun 2016; dan notasi iringan Tari Opak Abang dari Gilang Surya Saputra dan Dwi Prasetyo Hariansyah selaku orang yang berkecimpung di dunia musik tradisional, data didapat pada tanggal 9 Maret 2017. Selain dokumentasi dari narasumber, peneliti menggunakan kamera handphone atau kamera digital untuk mendokumentasikan proses latihan Tari Opak Abang pada tanggal 21 April 2017, jalannya pertunjukan Tari Opak Abang pada tanggal 22 April 2017, para pelaku pertunjukan Tari Opak Abang pada tanggal 22 April 2017, para penonton pertunjukan Tari Opak Abang pada tanggal 22 April 2017, perlengkapan busana Tari Opak Abang pada tanggal 30 Januari 2017 dan 21 April 2017, dan alat-alat musik yang digunakan dalam mengiringi Tari Opak Abang pada tanggal 30 Januari 2017 dan 21 April 2017.

\subsubsection{Wawancara}

Wawancara merupakan suatu proses tanya jawab antara pewawancara dengan orang yang diwawancara dengan tujuan memperoleh informasi yang dibutuhkan oleh peneliti. Wawancara merupakan metode pengumpulan data yang langsung dari sumbernya tentang hal-hal yang berkaitan dengan objek penelitian (Widoyoko 2012:40).

Pada penelitian mengenai seni pertunjukan, narasumber yang dapat diwawancarai oleh peneliti, yaitu: 1) seniman penyaji atau pelaku; 2) penanggap (penyelenggara); dan 3) masyarakat umum atau penonton (Maryono 2011:88). Penelitian mengenai bentuk dan fungsi pertunjukan Tari Opak Abang 
mewawancara beberapa narasumber guna melengkapi penelitan yaitu seniman penyaji atau pelaku, dan masyarakat umum atau penonton.

Peneliti mewawancara para pelaku pertunjukan Tari Opak Abang mengenai bentuk pertunjukan Tari Opak Abang, seperti komponen-komponen bentuk pertunjukan, struktur pertunjukan Tari Opak Abang, dan fungsi pertunjukan Tari Opak Abang. Peneliti tidak hanya mewawancarai pelaku pertunjukan Tari Opak Abang, akan tetapi juga melengkapi data penelitian dengan mewawancarai penonton pertunjukan Tari Opak Abang mengenai kesan dan pesan setelah menyaksikan pertunjukan Tari Opak Abang.

Wawancara dilakukan dengan bantuan daftar pertanyaan yang telah dibuat oleh peneliti, buku catatan kecil dan ballpoint, serta blangko biodata narasumber yang telah dibuat oleh peneliti, untuk mempermudah peneliti menggunakan fasilitas perekam suara yang ada dalam handphone. Wawancara dilakukan oleh peneliti terhadap beberapa elemen dan pelaku seni Tari Opak Abang baik secara pribadi maupun kelompok, narasumber yang diwawancarai antara lain:

1. Bapak Aris Salamun beserta para pelaku pertunjukan Tari Opak Abang pada tanggal 22 Januari 2017, 30 Januari 2017, 21 April 2017, dan 22 April 2017 di Dusun Siranti, Desa Pasigitan, mengenai gambaran secara spesifik tentang bentuk dan fungsi seni pertunjukan Tari Opak Abang.

2. Masyarakat penikmat kesenian tradisional Opak Abang mengenai kesan dan pesan setelah menonton pertunjukkan Tari Opak Abang pada tanggal 22 April 2017 di Dusun Siranti, Desa Pasigitan. 


\subsection{Teknik Keabsahan Data}

Teknik keabsahan data adalah suatu proses untuk memastikan setiap data yang diperoleh adalah benar dan dapat dipercaya sangat relevan dengan apa yang sedang diteliti (Ibrahim 2015: 119). Moleong (dalam Ibrahim 2015: 120) menyebutkan empat kriteria keabsahan data, yaitu: derajat ketepercayaan (credibility); keteralihan (transferability); kebergantungan (dependability); dan kepastian (confirmability).

Penelitian tentang bentuk dan fungsi pertunjukan Tari Opak Abang menggunakan kriteria derajat ketepercayaan (credibility) untuk memeriksa keabsahan data. Derajat ketepercayaan (credibility) digunakan dengan cara melihat hubungan antara data dengan sumber data (kredibilitas sumber), antara data dengan teknik penggalian data (kredibilitas teknik), dan pembuktian data di lapangan (kredibilitas informasi). Berdasarkan kriteria derajat ketepercayaan (credibility) pemeriksaan keabsahan data penelitian dapat menggunakan: 1) teknik perpanjangan keikutsertaan; 2) ketekunan pengamatan; 3) triangulasi; 4) pengecekan sejawat; 5) kecukupan referensi; 6) kajian kasus negatif; dan 7) pengecekan anggota (Ibrahim 2015: 121-122). Peneliti menggunakan triangulasi untuk memeriksa keabsahan data penelitian tentang bentuk dan fungsi pertunjukan Tari Opak Abang. Triangulasi merupakan teknik pemeriksaan data dengan cara membanding-bandingkan antara sumber, teori, maupun metode/teknik penelitian (Ibrahim: 2015: 124). Triangulasi oleh Moleong (dalam Ibrahim 2015: 124) dibagi menjadi beberapa macam, yaitu: 1) sumber; 2) metode; dan 3) teori, 
sebagaimana yang digunakan peneliti dalam mengkaji bentuk dan fungsi pertunjukan Tari Opak Abang.

Triangulasi sumber berarti membandingkan data-data pengamatan yang didapat dari hasil wawancara dengan masing-masing narasumber. Triangulasi metode, peneliti membandingkan data yang dihasilkan dari beberapa teknik yang digunakan dalam penelitian, misalnya, membandingkan data hasil observasi dengan data hasil wawancara, data hasil wawancara dengan data dokumentasi, atau data dokumentasi dengan data hasil observasi. Triangulasi teori digunakan peneliti untuk membandingkan dan mengecek kesesuaian antara data penelitian yang diperoleh dengan teori-teori yang digunakan oleh peneliti (Ibrahim 2015: 125).

Pada triangulasi sumber, peneliti membandingkan dari sudut pandang diri sendiri dengan pendapat dari hasil wawancara dengan berbagai narasumber yaitu para penonton pertunjukan Tari Opak Abang, para pelaku pertunjukan Tari Opak Abang, dan orang yang berkecimpung di dunia tari. Peneliti juga menggunakan triangulasi metode dengan cara membandingkan satu sama lain data-data yang dihasilkan dari observasi, dokumentasi, dan wawancara, selain itu, peneliti menggunakan triangulasi teori untuk menyesuaikan data-data mengenai bentuk dan fungsi pertunjukan Tari Opak Abang yang telah diperoleh di lapangan dengan teori-teori yang digunakan peneliti. 


\subsection{Teknik Analisis Data}

Miles \& Huberman dalam Sugiyono (2015: 330) menyatakan bahwa aktivitas dalam analisis data kualitatif dilakukan secara interaktif dan berlangsung secara terus-menerus. Analisis data kualitatif terdiri dari tiga alur kegiatan yang terjadi secara bersamaan, yaitu: reduksi data, penyajian data, dan penarikan kesimpulan/verivikasi (Miles \& Huberman 1992:16). Berikut komponenkomponen analisis data yang disajikan dalam bagan 3.1.

Bagan 3.1. Komponen-komponen analisis data: Model Interaktif

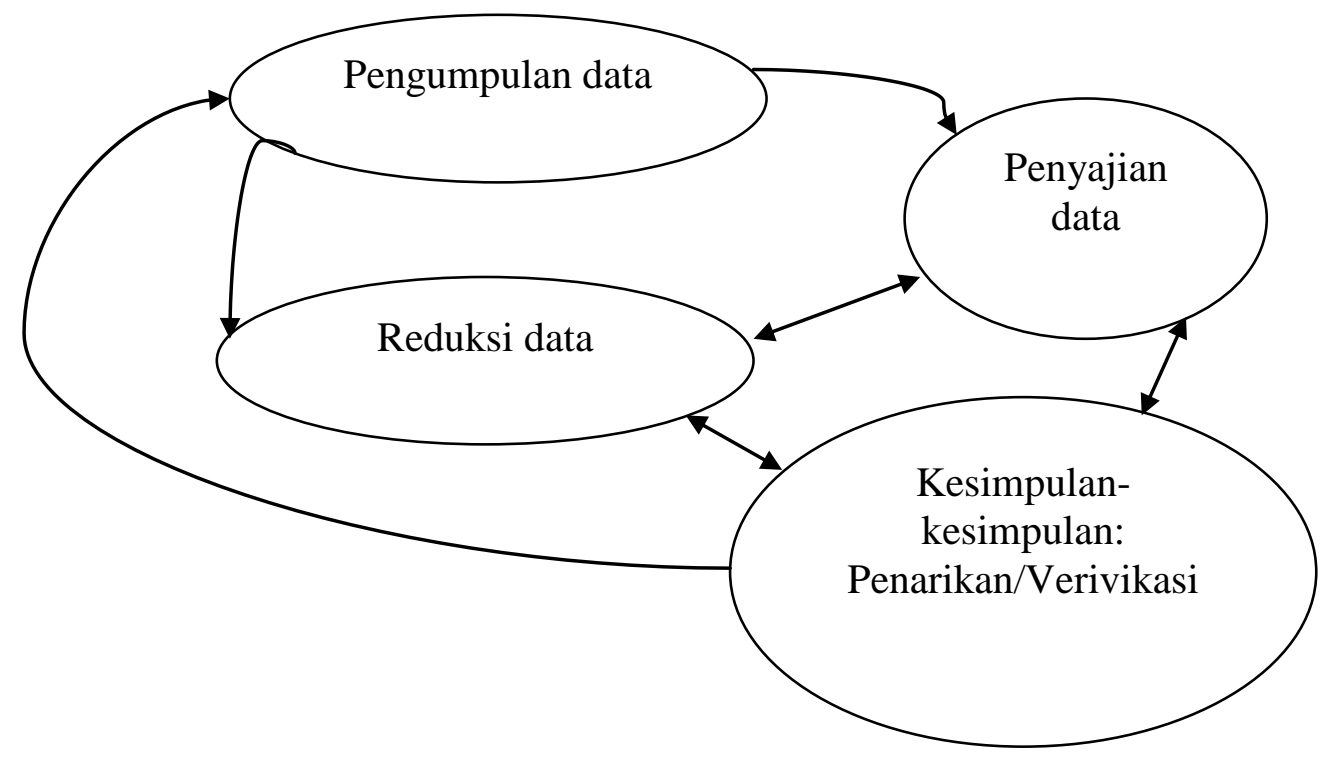

(Sumber: Miles \& Huberman 1992:20)

Berdasarkan bagan 3.1. dapat diketahui komponen-komponen analisis data yaitu: reduksi data, penyajian data, dan penarikan kesimpulan/verivikasi.

\subsubsection{Reduksi data}

Reduksi data merupakan proses penyederhanaan, pemilihan data-data hasil dari observasi, dokumentasi, dan wawancara di lokasi penelitian Miles \& 
Huberman 1992:16). Peneliti dapat memilah-milah data penelitian yang akan digunakan dan yang tidak digunakan. Proses pemilihan data-data penelitian disesuaikan dengan topik bentuk dan fungsi pertunjukan Tari Opak Abang. Datadata yang melalui proses reduksi data, yaitu: gambaran umum lokasi penelitian, wawancara mengenai sejarah dan latar belakang Tari Opak Abang, wawancara dengan para pelaku pertunjukan, deskripsi mengenai bentuk dan fungsi pertunjukan Tari Opak Abang beserta komponen-komponen yang mendukung.

\subsubsection{Penyajian Data}

Penyajian data merupakan proses di mana peneliti dapat memahami apa yang sedang terjadi dan apa yang harus dilakukan. Penyajian dapat diartikan sebagai sekumpulan informasi yang tersusun yang memberi kemungkinan adanya penarikan kesimpulan dan pengambilan tindakan (Miles \& Huberman 1992: 17). Pada proses penyajian data, peneliti meringkas, menyusun, kemudian mengorganisasikan data-data penelitian sesuai dengan kategori sifatnya masingmasing, seperti komponen-komponen pendukung bentuk pertunjukan Tari Opak Abang, yaitu: tema; gerak; iringan; tata rias dan busana; tata pentas; tata suara; tata lampu; pelaku pertunjukan dan penonton, dan fungsi-fungsi pertunjukan Tari Opak Abang.

\subsubsection{Penarikan kesimpulan/verifikasi}

Penarikan kesimpulan/verivikasi yaitu proses peneliti dalam mencari arti benda-benda dengan mencatat keteraturan, pola-pola, penjelasan, konfigurasikonfigurasi yang mungkin, alur sebab-akibat, dan proposisi. Kesimpulankesimpulan awal peneliti mulanya belum jelas, kemudian meningkat menjadi 
lebih rinci (Miles \& Huberman 1992: 19). Pada proses penarikan kesimpulan/verivikasi, peneliti melakukan tinjauan ulang terhadap data-data penelitian yang didapat di lapangan mengenai bentuk dan fungsi pertunjukan Tari Opak Abang, dan melakukan uji validitas antara data-data yang didapat dengan observasi, dokumentasi, dan wawancara yang telah dilakukan di lapangan. Datadata mengenai bentuk dan fungsi pertunjukan Tari Opak Abang selanjutnya diuraikan secara rinci dalam bentuk laporan hasil penelitian. 


\section{BAB IV \\ HASIL PENELITIAN DAN PEMBAHASAN}

\subsection{Gambaran Umum Lokasi Penelitian}

Kecamatan Boja merupakan salah satu dari 20 kecamatan yang ada di Kabupaten Kendal. Wilayah Kecamatan Boja merupakan daerah dataran tinggi dengan ketinggian mencapai 350-500 meter di atas permukaan laut (Sumber: bappeda.kendalkab.go.id). Wilayah Kecamatan Boja dapat dilihat pada gambar 4.1.

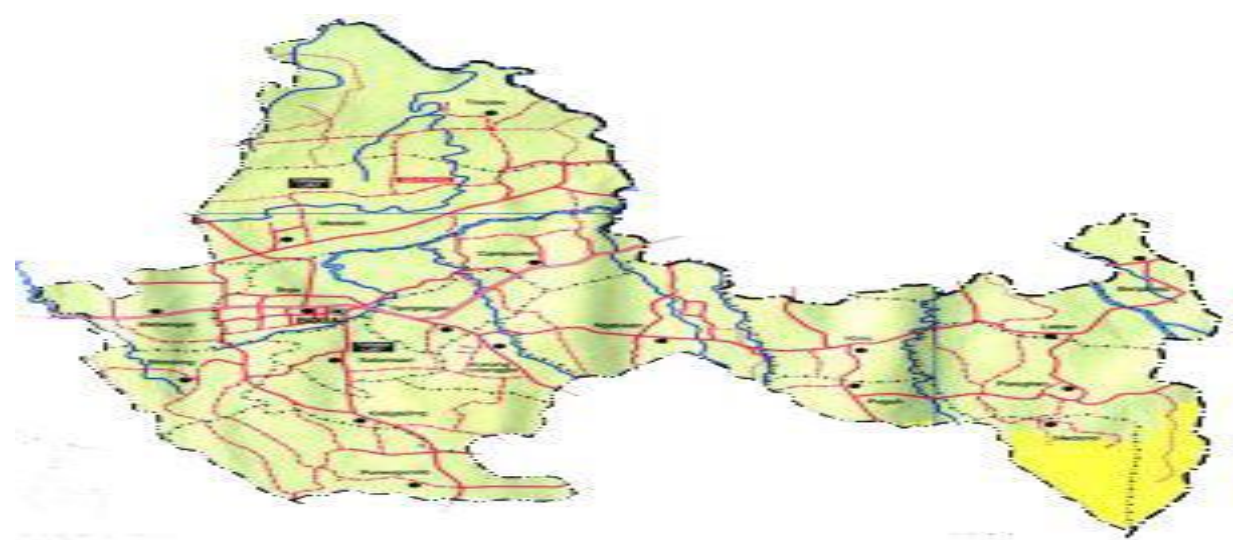

Gambar 4.1. Peta Wilayah Kecamatan Boja.

(Sumber: bappeda.kendalkab.go.id)

Berdasarkan gambar 4.1. letak geografis Kecamatan Boja berada di $7^{0} 02$ ' 58 " LS $-7^{0} 08^{\prime} 53^{\prime \prime}$ LS dan $109^{0} 15^{\prime} 08^{\prime \prime}$ BT $-110^{0} 21$ ' $85^{\prime \prime}$ BT. Kecamatan Boja terletak di sebelah selatan wilayah Kabupaten Kendal. Batas-batas wilayah sebelah Utara berbatasan dengan Kecamatan Kaliwungu Selatan, sebelah Selatan berbatasan dengan Kecamatan Limbangan, dan sebelah Barat berbatasan dengan Kecamatan Singorojo, serta sebelah Timur berbatasan dengan Kota Semarang. Kecamatan Boja memiliki luas wilayah $64.10 \mathrm{~km}^{2}$ atau sebesar $6.39 \%$ wilayah 
Kabupaten Kendal secara administratif. Kecamatan Boja terdiri dari 18 desa. Jumlah dusun/dukuh dari total 18 desa sebanyak 97 dusun (Sumber: bappeda.kendalkab.go.id). Jumlah Rukun Warga (RW) sebanyak 112 RW dan jumlah Rukun Tetangga (RT) berjumlah 463 RT seperti yang disajikan dalam tabel 4.1.

Tabel 4.1. Jumlah Dusun/Dukuh, RW, dan RT di Kecamatan Boja

\begin{tabular}{|c|c|c|c|c|}
\hline NO & Desa/Kelurahan & Dusun/Dukuh & $\begin{array}{c}\text { Rukun Warga } \\
(\mathrm{RW})\end{array}$ & $\begin{array}{c}\text { Rukun } \\
\text { Tetangga (RT) }\end{array}$ \\
\hline 1 & Purwogondo & 6 & 6 & 18 \\
2 & Kaligading & 6 & 7 & 30 \\
3 & Salamsari & 6 & 6 & 16 \\
4 & Blimbing & 5 & 5 & 24 \\
5 & Bebengan & 4 & 8 & 49 \\
6 & Boja & 10 & 10 & 60 \\
7 & Meteseh & 8 & 8 & 48 \\
8 & Trisobo & 2 & 3 & 19 \\
9 & Campurejo & 5 & 6 & 40 \\
10 & Tampingan & 5 & 5 & 23 \\
11 & Karangmanggis & 4 & 4 & 13 \\
12 & Ngabean & 8 & 9 & 28 \\
13 & Kliris & 8 & 8 & 10 \\
14 & Puguh & 3 & 5 & 6 \\
15 & Medono & 2 & 3 & 20 \\
16 & Pasigitan & 6 & 10 & 15 \\
17 & Leban & 5 & 5 & 22 \\
18 & Banjarejo & 4 & 4 & 463 \\
\hline \multicolumn{5}{|l|}{} \\
\hline
\end{tabular}

(Sumber: Statistik Daerah Kabupaten Kendal 2016)

Berdasarkan tabel 4.1. dapat diketahui bahwa Desa Pasigitan merupakan salah satu dari 18 desa yang ada di Kecamatan Boja. Data statistik Kabupaten Kendal tahun 2016 menunjukan bahwa Desa Pasigitan mempunyai 6 dusun atau dukuh yang di dalamnya terdapat 10 Rukun Warga (RW) dan 20 Rukun Tetangga 
(RT). Peneliti mengulas tentang wilayah Kecamatan Boja karena Tari Opak Abang berkembang di Desa Pasigitan yang merupakan salah satu desa di Kecamatan Boja.

\subsubsection{Kondisi dan Letak Geografis Desa Pasigitan, Kecamatan Boja, Kabupaten Kendal}

Desa Pasigitan merupakan salah satu desa yang ada di Kecamatan Boja, Kabupaten Kendal. Desa Pasigitan terletak $18 \mathrm{~km}$ dari Universitas Negeri Semarang (UNNES), kampus Sekaran, Gunungpati. Ketinggian Desa Pasigitan mencapai \pm 1000 meter di atas permukaan laut dengan suhu udara rata-rata $21^{0}-26^{0}$ Celcius. Batas-batas wilayah Desa Pasigitan antara lain: 1) Utara: Desa Leban; 2) Timur: Kabupaten Semarang; 3) Selatan: Desa Medono; 4) Barat: Desa Puguh. Desa Pasigitan memiliki luas wilayah sebesar 5.441 hektare (ha). Pembagian wilayah Desa Pasigitan berdasarkan data statistik Desa Pasigitan tahun 2016 yang disajikan dalam tabel 4.2.

Tabel 4.2. Jumlah Dusun, RW, dan RT di Desa Pasigitan

\begin{tabular}{|c|c|c|c|}
\hline \multirow{2}{*}{ NO } & \multirow{2}{*}{ Dukuh/Dusun } & RW & RT \\
\cline { 3 - 4 } & Ngumpul & 1 & 2 \\
2 & Suringgono & 1 & 2 \\
3 & Krajan & 3 & 6 \\
4 & Sekar Gadung & 3 & 6 \\
5 & Siranti & 1 & 2 \\
6 & Gunung Munding & 1 & 2 \\
\hline
\end{tabular}

(Sumber: Statistik Daerah Desa Pasigitan 2016)

Tabel 4.2. memuat informasi bahwa Desa Pasigitan memiliki 6 dukuh/dusun,

yaitu: 1) Dukuh/Dusun Ngumpul; 2) Dukuh/Dusun Suringgono;

Dukuh/Dusun Krajan; 4) Dukuh/Dusun Sekar Gadung; 5) Dukuh/Dusun Siranti; 
6) Dukuh/Dusun Gunung Munding. Desa Pasigitan terdapat 10 Rukun Warga (RW) dan 20 Rukun Tetangga (RT) yang tersebar ke dalam 6 dukun/dusun. Tari Opak Abang merupakan tari rakyat yang berada dan berkembang di Desa Pasigitan, tepatnya di kediaman Bapak Aris Salamun seperti yang terlihat pada foto 4.1 .

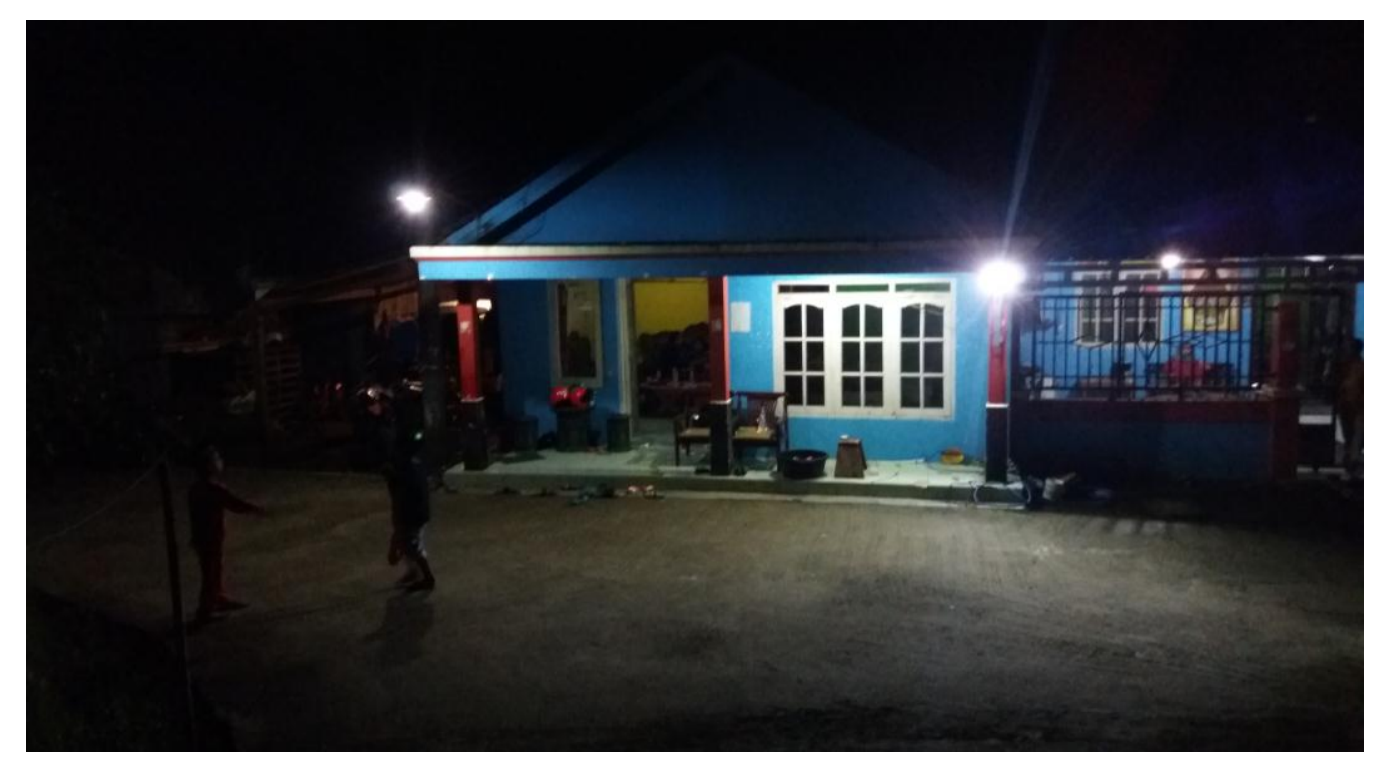

Foto 4.1. Kediaman Bapak Aris Salamun

(Sumber: Dokumentasi Mawasti, 22 April 2017)

Berdasarkan foto 4.1. diketahui bahwa lokasi penelitian terletak di kediaman Bapak Aris Salamun, Dusun Siranti RT 02 RW 08, Desa Pasigitan, Kecamatan Boja, Kabupaten Kendal. Peneliti melewati jalanan yang berliku untuk dapat mencapai Desa Pasigitan dari Universitas Negeri Semarang. Desa Pasigitan dapat dikatakan sebagai daerah yang masih pelosok. Waktu tempuh dari Universitas Negeri Semarang menuju Desa Pasigitan kurang lebih 45 menit dengan menggunakan kendaraan roda dua. 


\subsubsection{Data Kependudukan Desa Pasigitan}

\subsubsection{Penduduk Desa Pasigitan}

Jumlah penduduk Desa Pasigitan pada tahun 2016 sebanyak 2.723 jiwa, terdiri dari 1.407 laki-laki, dan 1.316 perempuan (Sumber: Statistik Daerah Desa Pasigitan 2016). Jumlah penduduk Desa Pasigitan menurut kelompok umur dan jenis kelamin disajikan dalam tabel 4.3.

Tabel 4.3. Jumlah Penduduk Desa Pasigitan Berdasarkan Kelompok Umur dan Jenis Kelamin

\begin{tabular}{|c|c|c|c|}
\hline \multirow{2}{*}{ Kelompok Umur } & \multicolumn{2}{|c|}{ Penduduk } & \multirow{2}{*}{ Jumlah } \\
\cline { 2 - 3 } & Laki-laki & Perempuan & 209 \\
$00-04$ & 120 & 89 & 189 \\
$05-09$ & 103 & 86 & 213 \\
$10-14$ & 108 & 105 & 229 \\
$15-19$ & 127 & 102 & 209 \\
$20-24$ & 99 & 110 & 225 \\
$25-29$ & 118 & 107 & 173 \\
$30-34$ & 89 & 84 & 192 \\
$35-39$ & 92 & 100 & 226 \\
$40-44$ & 114 & 112 & 208 \\
$45-49$ & 115 & 93 & 179 \\
$50-54$ & 93 & 86 & 113 \\
$55-59$ & 58 & 55 & 96 \\
$60-64$ & 42 & 54 & 84 \\
$65-69$ & 45 & 39 & 78 \\
$70-74$ & 37 & 41 & 100 \\
\hline $75+$ & 47 & 53 & 2.723 \\
\hline \multicolumn{4}{|c|}{ Jumlah : } \\
\hline Tahun 2016 & 1.407 & 1.316 & \\
\hline
\end{tabular}

(Sumber: Statistik Daerah Desa Pasigitan 2016)

Berdasarkan tabel 4.3. di atas dan wawancara yang dilakukan oleh peneliti kepada 11 pelaku pertunjukan Tari Opak Abang dalam paguyuban kesenian Sri Langen Budaya Bumi milik Bapak Aris Salamun, tercatat 8 orang termasuk di dalamnya 6 orang pemusik, 1 orang sindhen, dan salah seorang penari berada di 
rentang usia 35-64 tahun, sedangkan 3 penari lainnya berada pada rentang usia 1019 tahun.

\subsubsection{Mata Pencaharian Penduduk Desa Pasigitan}

Mata pencaharian penduduk Desa Pasigitan sebagian besar terletak di sektor pertanian, urutan kedua dan ketiga adalah sektor industri pengolahan dan sektor keuangan jasa. Berikut perincian mata pencaharian penduduk di Desa Pasigitan yang disajikan dalam tabel 4.4 .

Tabel 4.4. Mata Pencaharian Penduduk Desa Pasigitan

\begin{tabular}{|c|l|c|}
\hline NO & \multicolumn{1}{|c|}{ Mata Pencaharian } & $\begin{array}{c}\text { Jumlah Penduduk } \\
\text { Tahun 2016 }\end{array}$ \\
\hline 1 & Sektor Pertanian & 1.298 \\
2 & Sektor Pertambangan Penggalian & 8 \\
3 & Sektor Industri Pengolahan & 218 \\
4 & Sektor Listrik, Gas, dan Air Minum & 1 \\
5 & Sektor Bangunan & 122 \\
6 & Sektor Perdagangan, Hotel, dan Restoran & 89 \\
7 & Sektor Pengangkutan dan Persewaan & 52 \\
8 & Sektor Keuangan dan Jasa & 163 \\
\hline
\end{tabular}

(Sumber: Statistik Daerah Desa Pasigitan 2016)

Pada tabel 4.4. diperlihatkan bahwa penduduk Desa Pasigitan yang bekerja sebagai buruh di sektor pertanian sebanyak 1.298 jiwa pada tahun 2016. Masyarakat pelaku pertunjukan Tari Opak Abang mayoritas berprofesi sebagai petani, hal ini sesuai dengan data mata pencaharian penduduk Desa Pasigitan yang sebagian besar bekerja sebagai petani. Profesi sebagai petani mempengaruhi tata busana Opak Abang, yaitu dengan adanya pemakaian kaos kaki putih. Pada awalnya, penari Opak Abang menggunakan kaos kaki putih bertujuan untuk menutupi kekurangan pada kakinya karena keseharian ketika pergi bertani tidak 
pernah memakai alas kaki, akan tetapi kaos kaki pada Tari Opak Abang justru ditetapkan menjadi tata busana pada setiap pertunjukan Tari Opak Abang.

\subsubsection{Agama Penduduk Desa Pasigitan}

Penduduk Desa Pasigitan semua memeluk agama Islam dengan jumlah 2.723 jiwa (100\%) dari total seluruh penduduk yang ada, berdasarkan data statistik Desa Pasigitan tahun 2016. Penduduk Desa Pasigitan seluruhnya memeluk agama Islam. Hal ini memiliki kesesuaian dengan Tari Opak Abang yang memiliki ciri khas melayu pada tariannya dan syair lagu yang memuat tentang syiar agama. Agama dan jumlah pemeluknya di Desa Pasigitan dapat disajikan dalam tabel 4.5.

Tabel 4.5. Jumlah Pemeluk Agama di Desa Pasigitan

\begin{tabular}{|c|c|c|}
\hline NO & Agama & Jumlah Pemeluk Tahun 2016 \\
\hline 1 & Islam & 2.723 \\
2 & Kristen & 0 \\
3 & Katholik & 0 \\
4 & Budha & 0 \\
5 & Hindhu & 0 \\
6 & Konghucu & 0 \\
\hline
\end{tabular}

(Sumber: Statistik Daerah Desa Pasigitan 2016)

Desa Pasigitan merupakan desa dengan seluruh penduduknya memeluk agama Islam. Tari Opak Abang sebagai tari yang berkembang di Desa Pasigitan memiliki ciri khas yang bercorak agama Islam dan melayu, hal ini terlihat dari tata busana Tari Opak Abang yang menggunakan pakaian lengan panjang, celana panjang, kain penutup kepala seperti kerudung, dan kain songket khas melayu. Iringan Tari Opak Abang mempunyai syair yang isinya tentang penyebaran agama Islam. Maka dari itu, berdasarkan tabel 4.5. Tari Opak Abang mempunyai ciri 
khas melayu dengan corak agama Islam sebagai perwujudan masyarakat Desa Pasigitan yang seluruhnya beragama Islam.

\subsubsection{Pendidikan Penduduk Desa Pasigitan}

Desa Pasigitan memiliki sarana dan prasarana yang cukup memadai untuk pendidikan. Pemerintah Kabupaten Kendal sejak tahun 2013 telah menetapkan aturan Wajib Belajar 12 Tahun. Pada tahun 2016, terdapat penduduk sebanyak 324 jiwa tidak/belum tamat Sekolah Dasar (SD), penduduk yang tamat SD sebanyak 1.341 jiwa, tamat Sekolah Menengah Pertama (SMP) atau sederajat sebanyak 473 jiwa, tamat Sekolah Menengah Atas (SMA) atau sederajat sebanyak 173 jiwa, dan penduduk yang tamat Akademi atau Perguruan Tinggi (PT) sebanyak 21 jiwa. Perincian tingkat pendidikan yang ada di Desa Pasigitan dapat dilihat pada tabel 4.6.

Tabel 4.6. Pendidikan di Desa Pasigitan

\begin{tabular}{|c|c|c|}
\hline NO & Pendidikan & Jumlah \\
\hline 1 & Tidak/Belum tamat SD & 324 \\
2 & Tamat SD & 1.341 \\
3 & Tamat SMP/sederajat & 473 \\
4 & Tamat SMA/sederajat & 173 \\
5 & Tamat Akademi/PT & 21 \\
\hline
\end{tabular}

(Sumber: Statistik Daerah Desa Pasigitan 2016)

Tabel 4.6. memperjelas bahwa pelaku pertunjukan Tari Opak Abang paling banyak mengemban pendidikan sampai jenjang Sekolah Dasar (SD), hal ini sesuai dengan hasil wawancara peneliti terhadap seluruh narasumber dan data statistik pendidikan di Desa Pasigitan yang menyebutkan bahwa penduduk tamat SD 
sebanyak 1.341 jiwa yang artinya, Desa Pasigitan memiliki penduduk paling banyak tamatan Sekolah Dasar (SD).

\subsubsection{Kesenian di Desa Pasigitan}

Desa Pasigitan mempunyai berbagai macam kesenian yang tersebar pada 5 dari 6 dusun/dukuh yang ada di Desa Pasigitan, diantaranya Dusun Krajan, Dusun Ngumpul, Dusun Sekar Gadung, dan Dusun Siranti, hanya Dusun Gunung Munding yang belum mempunyai kesenian yang berkembang di dalamnya. Dusun Krajan memiliki kesenian Kuda Lumping, Rebana, Dangdut dan Wayang Orang, akan tetapi Wayang Orang di Dusun Krajan sekarang sudah tidak aktif lagi. Selanjutnya, Dusun Ngumpul memiliki kesenian Kethoprak. Dusun Suringgono terdapat kesenian Rebana yang sekarang tidak aktif lagi. Dusun Sekar Gadung ada kesenian Rebana dan Wayang Orang, dan keduanya sudah tidak aktif. Terakhir, Desa Pasigitan memiliki tari rakyat yang berkembang di Dusun Siranti dan menjadi andalan yaitu Tari Opak Abang. Tari Opak Abang merupakan tari rakyat yang masih terus dipertahankan sampai tahun 2017 (Sumber: pasigitanasri.blogspot.com).

\subsection{Latar Belakang Tari Opak Abang}

\subsubsection{Sejarah Tari Opak Abang}

Tari Opak Abang memasuki Desa Pasigitan pada tahun 1956. Tari Opak Abang dikembangkan pertama kali di Desa Pasigitan oleh Bapak Kusno yang berasal dari Desa Cepoko, Gunungpati. Sejarah Tari Opak Abang dijelaskan oleh Bapak Aris Salamun dalam wawancara pada tanggal 22 Januari 2017 sebagai berikut. 
“Tari Opak Abang memasuki Desa Pasigitan pertama kali pada tahun 1956. Pada waktu itu, Mbah Kusno semasa muda yang berasal dari Desa Cepoko menikah dengan orang Desa Pasigitan, setelah itu beliau tinggal menetap di Desa Pasigitan dan mengembangkan Tari Opak Abang di sini dengan nama Gambus Pancaroba. Masyarakat kemudian sering menyebut pertunjukan Gambus Pancaroba menjadi Opak Abang, karena kethoprak yang iringannya menggunakan terbang. Sebelum ke Dusun Siranti, Tari Opak Abang terlebih dahulu ada di Dusun Sekar Gadung selama 3 tahun, baru sekitar tahun 1959 masuk ke Dusun Siranti. Awalnya seluruh pemainnya laki-laki hingga tahun 1982, selanjutnya Tari Opak Abang dibawakan oleh penari wanita, dan penyanyinya juga wanita hingga sekarang. Setelah Bapak Kusno, penerusnya adalah Bapak Kumisan, Bapak Sapin, baru kemudian saya hingga sekarang”.

Berdasarkan hasil wawancara dengan Aris Salamun pada tanggal 22 Januari 2017 menunjukan bahwa awal mula adanya Tari Opak Abang ketika Bapak Kusno menikahi seorang gadis yang berasal dari Desa Pasigitan, karena pernikahan itulah Bapak Kusno kemudian tinggal menetap di Desa Pasigitan dan mengembangkan Tari Opak Abang di Desa Pasigitan dengan nama kelompok kesenian Gambus Pancaroba. Tari Opak Abang pada tahun 1959 resmi memasuki wilayah Dusun Siranti, karena sebelumnya Tari Opak Abang terlebih dahulu berkembang di Dusun Sekar Gadung selama kurang lebih tiga tahun. Tari Opak Abang pada masa awal kemunculannya dibawakan oleh kaum laki-laki baik untuk penari maupun pemain musik, hingga tahun 1982 Tari Opak Abang mulai dibawakan oleh penari wanita begitu juga penyanyinya. Generasi setelah Bapak Kusno, yaitu Bapak Kumisan yang kemudian melanjutkan kesenian tradisional Opak Abang di Desa Pasigitan. Penerus Opak Abang yang ke-3 yaitu Bapak Sapin, lalu dilanjutkan oleh Bapak Aris Salamun sebagai penerus Tari Opak Abang generasi ke-4 tepatnya pada era tahun 1980-an. 
Pada awal mula Tari Opak Abang hadir di Desa Pasigitan, pertunjukan Tari Opak Abang tidak pernah lepas dari kethoprak seperti penuturan Bapak Aris Salamun (30 Januari 2017).

"Pada waktu pertama kali ada, Tari Opak Abang selalu dipentaskan bersama dengan kethoprak, tetapi karena permintaan masyarakat sekarang yang ingin lebih praktis, maka pementasan Tari Opak Abang tidak lagi dilanjutkan dengan kethoprak melainkan sebatas hanya Tari Opak Abang".

Berdasarkan penuturan Bapak Aris Salamun pada wawancara tanggal 30 Januari 2017, Tari Opak Abang ditampilkan sebagai tarian pembuka dalam satu rangkaian pertunjukan kethoprak. Pada mulanya, Tari Opak Abang dan kethoprak merupakan satu rangkaian pertunjukan, akan tetapi seiring berjalannya waktu dan waktu yang disediakan untuk pementasan sedikit, maka dalam pertunjukan Opak Abang kini hanya sebatas Tari Opak Abang tanpa disertai dengan kethoprak.

Bapak Aris Salamun selaku penerus Tari Opak Abang mulai tahun 1980-an hingga sekarang, merupakan warga asli Desa Pasigitan yang tinggal di Dusun Siranti RT 02, RW 08. Bapak Aris Salamun mulai mengenal Tari Opak Abang pada saat beliau masih muda sesuai dengan penuturannya pada tanggal 30 Januari 2017 berikut.

"Saya mengikuti Opak Abang semenjak masih muda, hingga akhirnya saya mendirikan paguyuban milik saya sendiri pada 4 Juli 1959. Paguyuban milik saya awalnya bernama Langen Budaya Bumi, namun lambat laun ada beberapa wanita yang ikut bergabung mulai tahun 1982, maka nama paguyuban saya rubah menjadi Sri Langen Budaya Bumi. Sri artinya 'wanita', Langen berarti 'kesenangan', Budaya artinya 'budaya' itu sendiri, dan Bumi artinya 'asli' atau disebut asli milik rakyat".

Berdasarkan hasil wawancara dengan Bapak Aris Salamun pada tanggal 30

Januari 2017, diketahui bahwa menjabat sebagai ketua grup Sri Langen Budaya Bumi yang berdiri sejak 4 Juli 1959, mulanya nama grup atau paguyuban milik 
Bapak Aris Salamun adalah Langen Budaya Bumi, lalu ketika tahun 1982 mulai ada penari dan penyanyi wanita atau sindhen sehingga ditambahkan kata Sri di bagian depan nama paguyuban. Sri yang dimaksud adalah "kaum wanita", Langen dapat diartikan sebagai sebuah "kesenangan", Budaya bermakna "budaya" atau kebudayaan, dan Bumi bermakna "asli". Anggota paguyuban Sri Langen Budaya Bumi pada awalnya berjumlah 34 orang. Namun, sekarang anggota tinggal 25 orang karena mulai berkurangnya peminat.

Paguyuban yang dipimpin Bapak Aris Salamun pernah mengikuti berbagai event pertunjukan seperti yang dikatakan oleh Bapak Aris Salamun (30 Januari 2017).

"Pada tahun 1980 bulan Oktober, Tari Opak Abang ikut dalam acara Festival Pertunjukan Rakyat Tingkat Karesidenan di Purwodadi dan kemudian ikut lagi di tingkat Jawa Tengah tepatnya di Magelang bulan November. Saat masa jaya-jayanya, kami sering pentas di acara ulang tahun Kabupaten Kendal, bahkan tahun 1995 sempat turut menjadi bagian di ritual sedekah bumi Kabupaten Kendal, namun sekarang sedekah bumi sudah tidak diadakan lagi di Kendal".

Berdasarkan hasil wawancara dengan Bapak Aris Salamun tanggal 30 Januari 2017, diketahui bahwa Tari Opak Abang bersama grup Sri Langen Budaya Bumi pernah dipentaskan dalam acara Festival Pertunjukan Rakyat Tingkat Karesidenan di Purwodadi pada bulan Oktober tahun 1980 dan Festival Pertunjukan Rakyat Tingkat Jawa Tengah di Magelang pada bulan November tahun 1980. Paguyuban kesenian Sri Langen Budaya Bumi di saat masa kejayaannya tepatnya era tahun 1980-an hingga tahun 1990-an, sering tampil dalam acara Hari Ulang Tahun (HUT) Kabupaten Kendal. Tari Opak Abang pernah ditampilkan sebagai bagian 
dari ritual sedekah bumi yang dilaksanakan di Kabupaten Kendal pada tahun 1995, akan tetapi sekarang ritual sedekah bumi sudah tidak pernah diadakan.

Pada tahun 2005, Bapak Aris Salamun menjabat sebagai Kepala Kelurahan di Desa Pasigitan, kemudian beliau mementaskan Tari Opak Abang dalam rangka memperingati kemerdekaan Indonesia seperti penuturannya pada tanggal 22 Januari 2017 berikut.

"Sewaktu saya masih menjadi lurah di Desa Pasigitan, saya pernah mementaskan Tari Opak Abang untuk memperingati kemerdekaan Republik Indonesia pada tanggal 17 Agustus 2005. Tari Opak Abang selain pentas di Desa Pasigitan, juga pernah pentas di Jakarta. Pada waktu itu, Tari Opak Abang berkesempatan pentas di Taman Mini Indonesia Indah sebanyak dua kali di waktu yang berbeda".

Berdasarkan hasil wawancara dengan Bapak Aris Salamun pada tanggal 22 Januari 2017, Bapak Aris Salamun menyatakan bahwa saat beliau menjabat sebagai Kepala Kelurahan Desa Pasigitan pernah mementaskan Opak Abang dalam acara peringatan Hari Ulang Tahun Kemerdekaan Republik Indonesia tanggal 17 Agustus tahun 2005, Bapak Aris Salamun juga pernah memboyong Tari Opak Abang dua kali ke Taman Mini Indonesia Indah untuk tampil di Anjungan Jawa Tengah.

Tari Opak Abang bersama grup Sri Langen Budaya Bumi pernah tampil di UNNES pada tanggal 16 Januari 2016, hanya saja para penarinya dari mahasiswa Program Studi Pendidikan Seni Tari UNNES, sedangkan para pemusiknya dari Sri Langen Budaya Bumi seperti yang dikatakan Ibu Pujiati (22 Januari 2017).

"Setelah tampil di Unnes tanggal 16 Januari 2016 bersama dengan mahasiswa Pendidikan Seni Tari, kami sempat tampil pada suatu acara di Santosa Stable di bulan Mei. Berkolaborasi dengan tempat wisata Santosa Stable kami menampilkan Tari Opak Abang,lalu pada Bulan November Tari Opak Abang 
kembali tampil dalam rangka memperingati Hari Lansia dengan penari para lansia".

Pada kurun waktu tahun 2016, berdasarkan hasil wawancara dengan Ibu Pujiati pada tanggal 22 Januari 2017, Tari Opak Abang telah dipentaskan sebanyak tiga kali, yang pertama pada bulan Januari. Pada bulan Januari, Tari Opak abang dipentaskan di atas panggung B6 Fakultas Bahasa dan Seni Universitas Negeri Semarang dalam rangka Pesona Tari Jawa Tengah tanggal 16 Januari tahun 2016. Kedua, pada Mei tahun 2016, Tari Opak Abang tampil dan bekerja sama dengan tempat wisata Santosa Stable yang bertempat di Desa Leban, Kecamatan Boja, Kabupaten Kendal. Kemudian yang terakhir, Tari Opak Abang tampil di Desa Pasigitan dalam rangka memperingati Hari Lansia pada bulan November tahun 2016. Tahun 2017, Tari Opak Abang dipentaskan kembali di halaman depan rumah Bapak Aris Salamun pada tanggal 22 April 2017 pukul 20:30 WIB.

\subsection{Bentuk Pertunjukan Tari Opak Abang}

\subsubsection{Deskripsi Pertunjukan Tari Opak Abang}

Struktur penyajian pertunjukan Tari Opak Abang dibagi menjadi: 1) awal pertunjukan: diisi dengan sambutan dari Bapak Aris Salamun; 2) Inti pertunjukan: Gayung Seribu Gayung; Opak-Opak; Terang Bulan; dan Bunga Rampai; 3) akhir pertunjukan: berisi gerakan akhir Lambeyan sebagai tanda Tari Opak Abang telah selesai. Unsur pendukung pertunjukan Tari Opak Abang, yaitu: 1) tema; 2) gerak: meliputi deskripsi ragam gerak, unsur-unsur gerak, ruang, waktu, dan tenaga; 3) tata rias dan busana: meliputi proses rias dan proses busana; 4) musik/iringan: 
meliputi alat-alat musik dan notasi iringan tari; 5) tata pentas; 6) tata lampu/pencahayaan; 7) tata suara; 8) pelaku: meliputi penari dan pemain musik; dan 9) penonton.

\subsubsection{Struktur Pertunjukan Tari Opak Abang}

\subsubsection{Awal Pertunjukan Tari Opak Abang}

Pertunjukan Tari Opak Abang di Dusun Siranti, Desa Pasigitan, Kecamatan Boja, Kabupaten Kendal pada tanggal 22 April 2017 pukul 20:30 WIB, diawali dengan sambutan pembuka dari ketua grup Sri Langen Budaya Bumi, yaitu Bapak Aris Salamun seperti yang terlihat pada foto 4.2.

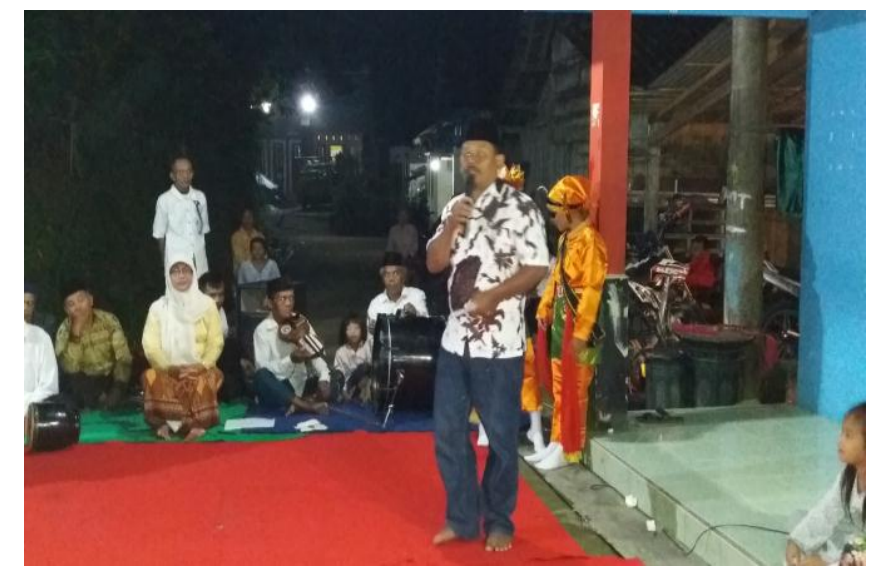

Foto 4.2. Sambutan Pembuka oleh Bapak Aris Salamun (Sumber: Dokumentasi Mawasti, 22 April 2017)

Pada foto 4.2. Bapak Aris Salamun sedang memberikan pidato sambutan untuk membuka pertunjukan Tari Opak Abang pada tanggal 22 April 2017 bertempat di depan kediaman Bapak Aris Salamun. Usai sambutan, dilanjutkan dengan pementasan Tari Opak Abang. Para penari bersiap di sisi kanan dan kiri karpet merah sebagai area pertunjukan dalam keadaan telah memakai kostum dan 
rias yang lengkap. Para pemusik Tari Opak Abang telah bersiap di belakang karpet merah seperti yang terlihat pada foto 4.3 .

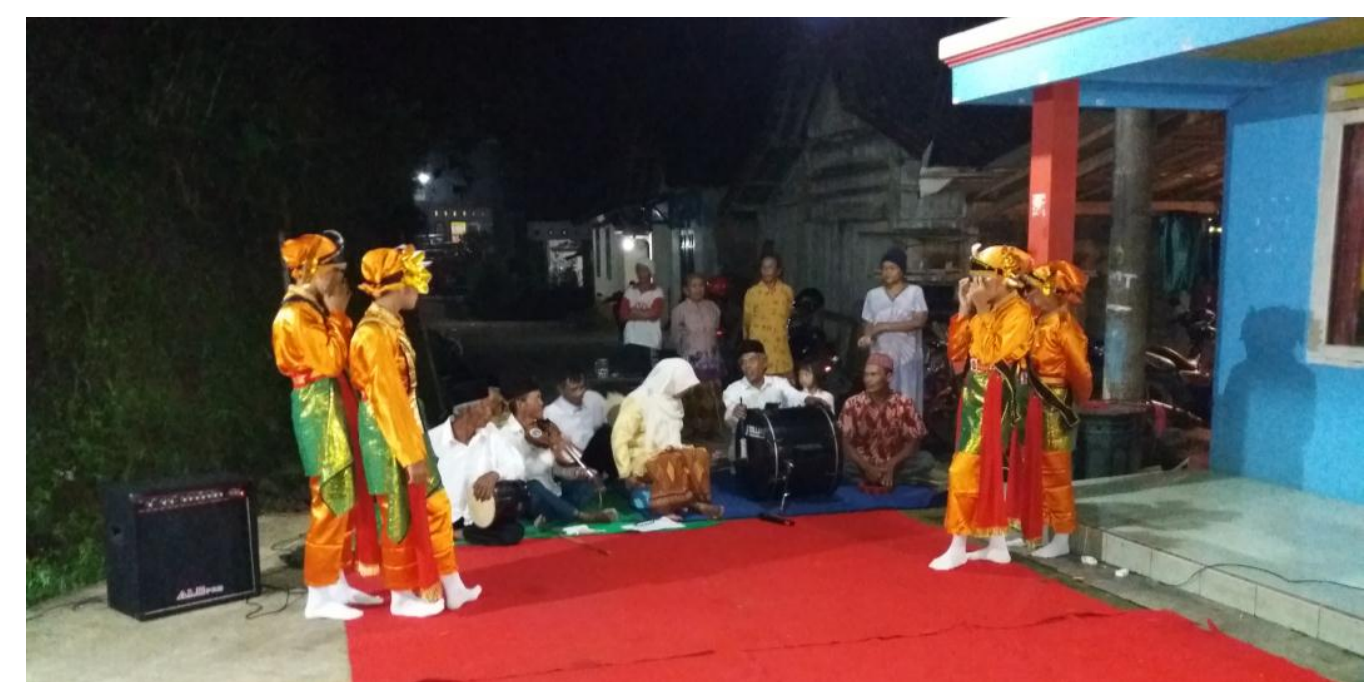

Foto 4.3. Penari Dan Pemusik Bersiap-Siap untuk Tampil

(Sumber: Dokumentasi Mawasti, 22 April 2017)

Berdasarkan foto 4.3. terlihat para penari dan para pemusik sedang mempersiapkan diri sebelum tampil. Tari Opak Abang memiliki 4 bagian, antara lain: 1) Gayung Seribu Gayung; 2) Opak-Opak; 3) Terang Bulan; dan 4) Bunga Rampai. Pada masing-masing bagian terdapat 2 ragam gerak dan setiap perpindahan urutan selalu menggunakan gerak transisi yaitu jalan melenggang (Lambeyan).

Musik iringan Tari Opak Abang telah siap, begitu juga dengan empat penari Opak Abang. Para pemusik mulai memainkan alat musiknya masing-masing, kemudian diikuti dengan penari yang Lambeyan memasuki area pertunjukan seperti yang ada pada foto 4.4 . 


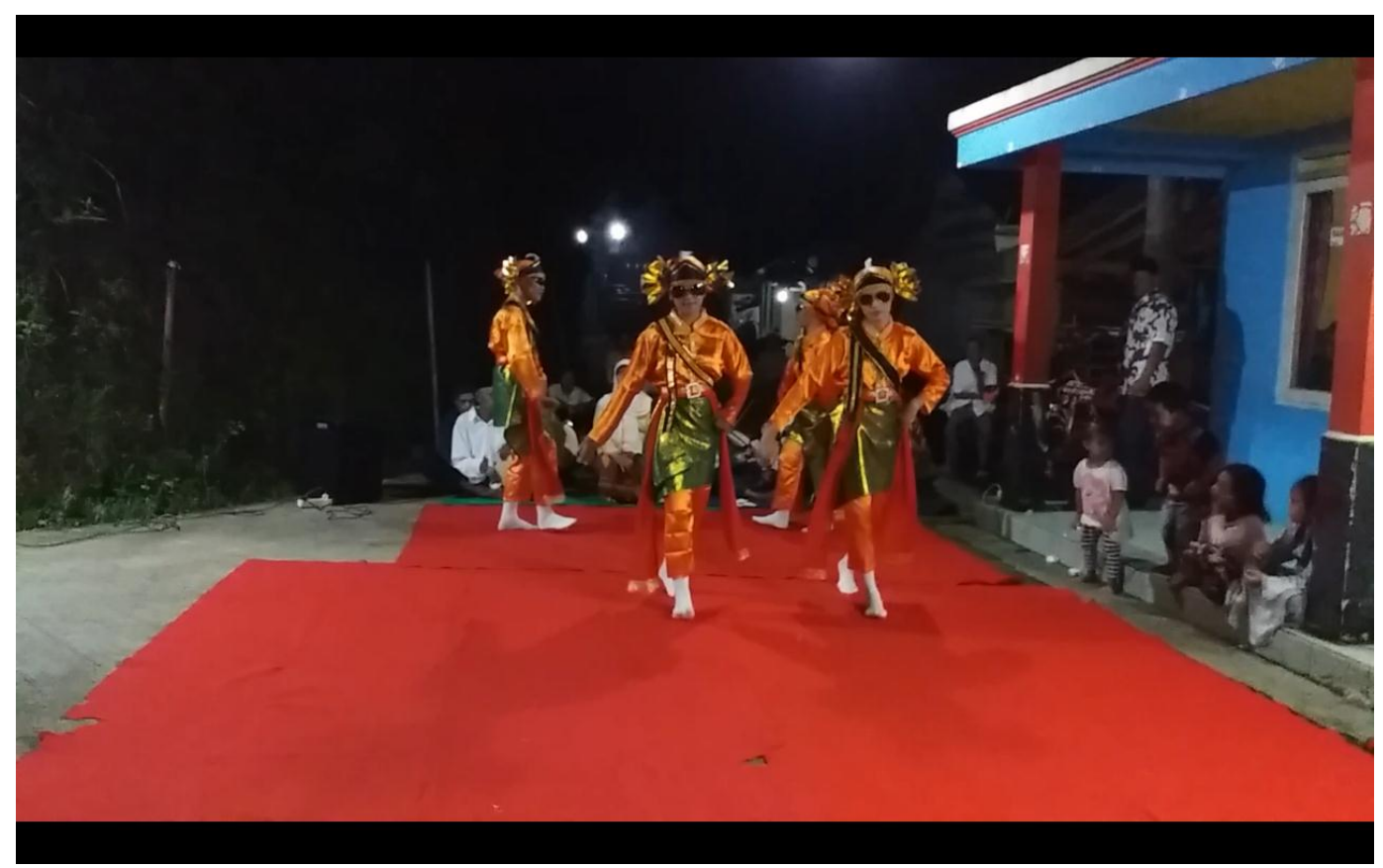

Foto 4.4. Penari Opak Abang Memasuki Area Pertunjukan

(Sumber: Dokumentasi Mawasti, 22 April 2017)

Foto 4.4. memperlihatkan para penari Opak Abang yang sedang melakukan

gerak Lambeyan ketika memasuki area pertunjukan. Gerakan Lambeyan dilakukan untuk mengawali Tari Opak Abang, selain itu Lambeyan juga dilakukan untuk transisi atau peralihan dari gerak satu ke gerak berikutnya. Gerak Lambeyan dilakukan secara berurutan kanan dan kiri sampai penari mencapai posisinya untuk memulai gerakan berikutnya.

\subsubsection{Inti Pertunjukan Tari Opak Abang}

Urutan pertunjukan inti Tari Opak Abang terdiri atas 4 bagian, yaitu: 1) Gayung Seribu Gayung; 2) Opak-Opak; 3) Terang Bulan; dan 4) Bunga Rampai. Berikut ialah urutan bagian inti Tari Opak Abang yang disajikan dalam foto 4.5, foto 4.6, gambar 4.7, dan foto 4.8 . 


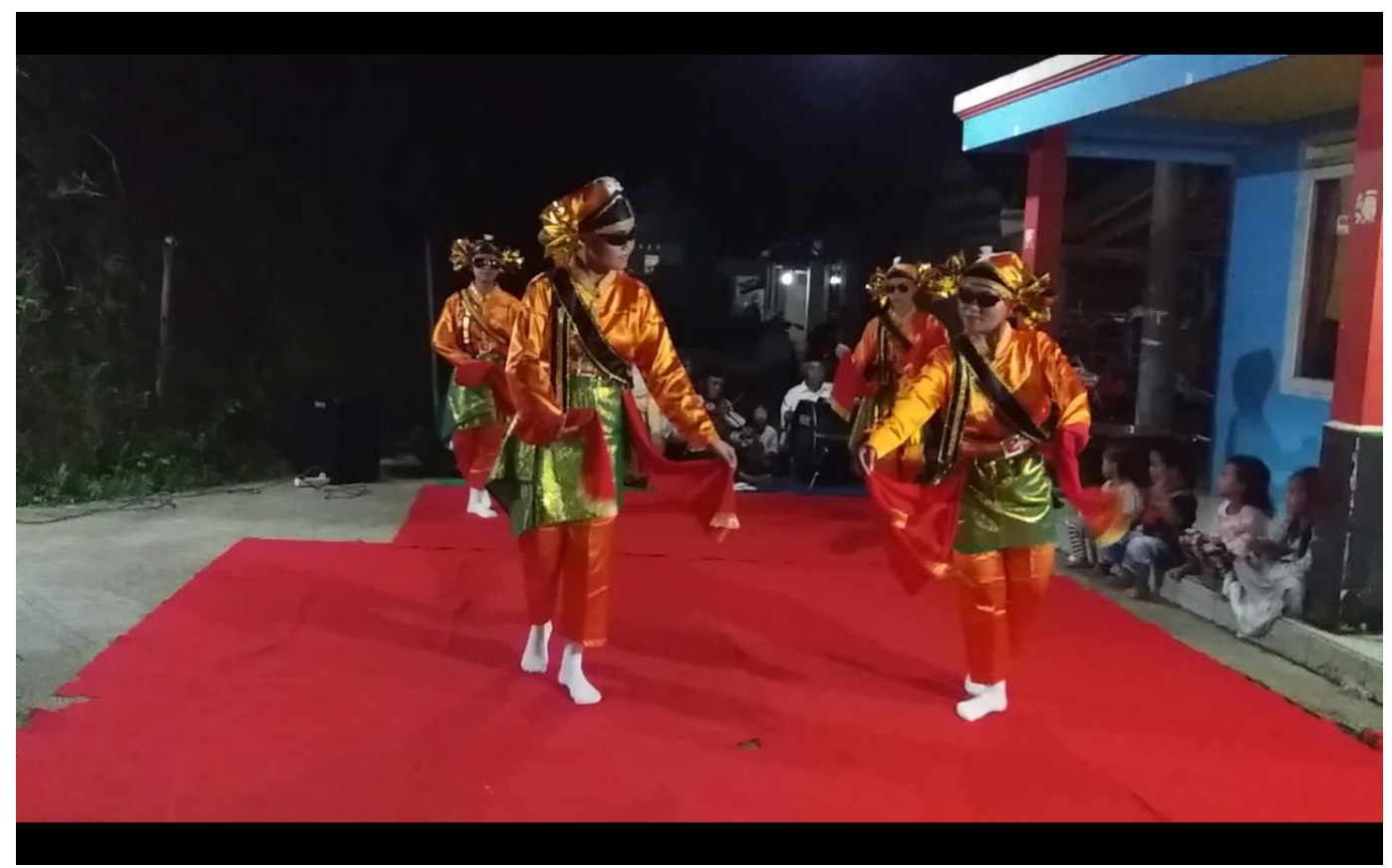

Foto 4.5. Bagian Pertama Tari Opak Abang: Gayung Seribu Gayung (Sumber: Dokumentasi Mawasti, 22 April 2017)

Berdasarkan foto 4.5. terlihat para penari Opak Abang menampilkan bagian pertama Tari Opak Abang, yaitu Gayung Seribu Gayung. Gerak pada bagian ini menyerupai kebyok dan kebyak sampur lalu dilanjut dengan gerakan yang menyerupai ukel karna. Bagian Gayung Seribu Gayung diulang sebanyak 2 kali. Pada bagian ini, dibuat beberapa variasi arah gerak yang saling berlawanan supaya sajian tari lebih menarik.

Bagian ke dua, setelah Gayung Seribu Gayung ialah Opak-Opak, akan tetapi usai menyelesaikan bagian Gayung Seribu Gayung, terlebih dahulu melakukan gerak peralihan, yaitu Lambeyan, baru kemudian memasuki bagian yang ke dua seperti pada foto 4.6 . 


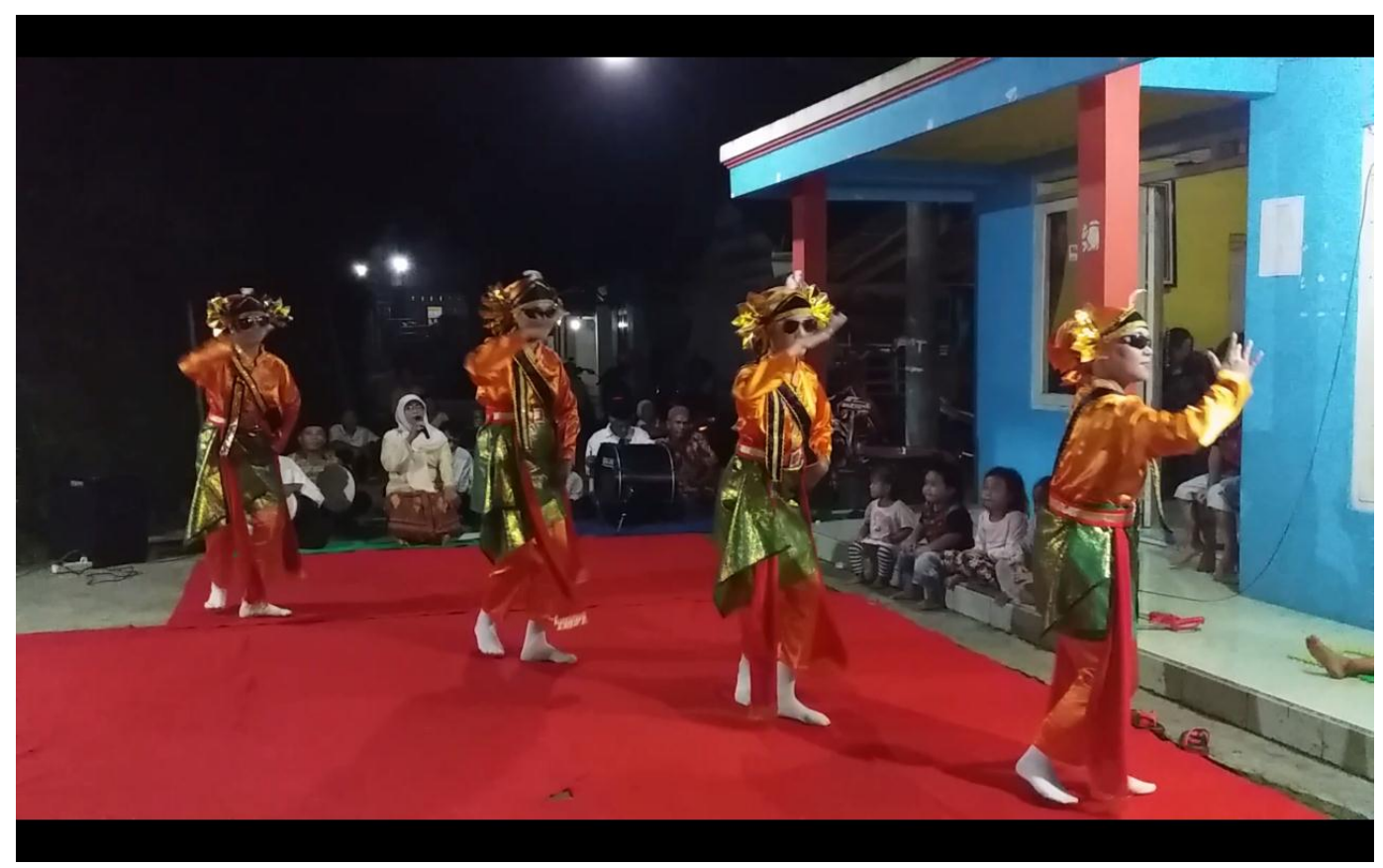

Foto 4.6. Bagian Ke Dua Tari Opak Abang: Opak-Opak

(Sumber: Dokumentasi Mawasti, 22 April 2017)

Berdasarkan foto 4.6. urutan ke dua Tari Opak Abang yaitu Opak-Opak.

Gerakan pada bagian ini lebih lincah dari bagian yang sebelumnya. Pada bagian Opak-Opak, penari melakukan gerak yang menyerupai ulap-ulap, lalu dilanjut dengan gerak menyerupai sampir sampur. Bagian Opak-Opak diulang sebanyak 2 kali. Arah hadap pada bagian ini yaitu serong kanan depan. Pada bagian ini, gerak Tari Opak Abang menggunakan beberapa permainan level gerak rendah dan level gerak sedang.

Bagian ke tiga yaitu Terang Bulan, setelah Opak-Opak selesai, para penari Opak Abang melakukan gerak Lambeyan terlebih dahulu sambil memposisikan diri ke dalam formasi berikutnya kemudian melakukan gerak pada bagian Terang Bulan seperti yang ada pada foto 4.7 . 


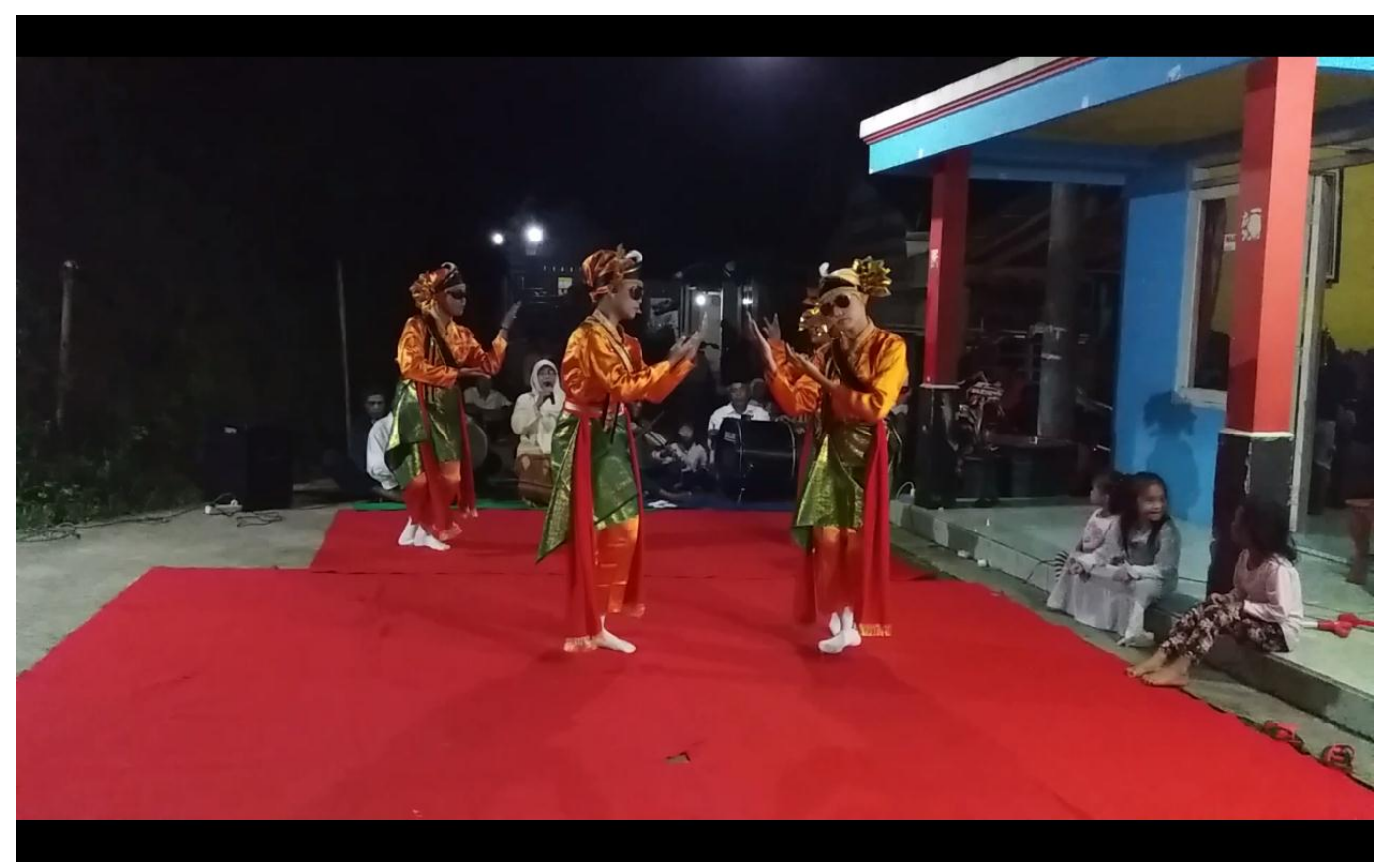

Foto 4.7. Bagian Ke Tiga Tari Opak Abang: Terang Bulan

(Sumber: Dokumentasi Mawasti, 22 April 2017)

Pada foto 4.7. terlihat bagian ke tiga Tari Opak Abang yaitu Terang Bulan. Pada bagian Terang Bulan, para penari melakukan gerak menyerupai ukel kedua tangan dan menyerupai menthang sembari kedua tangan seperti miwir sampur sambil mengentakkan salah satu kaki. Bagian ini diulang sebanyak 2 kali. Pada bagian ini, terdapat variasi gerak yang arahnya berlawanan serta permainan level gerak rendah dan level gerak sedang untuk menambah ketertarikan penonton terhadap pertunjukan Tari Opak Abang.

Pada bagian ke empat, Bunga Rampai, para penari melakukan gerak Lambeyan terlebih dahulu, lalu melanjutkan ke bagian Bunga Rampai seperti yang terlihat pada foto 4.8 . 


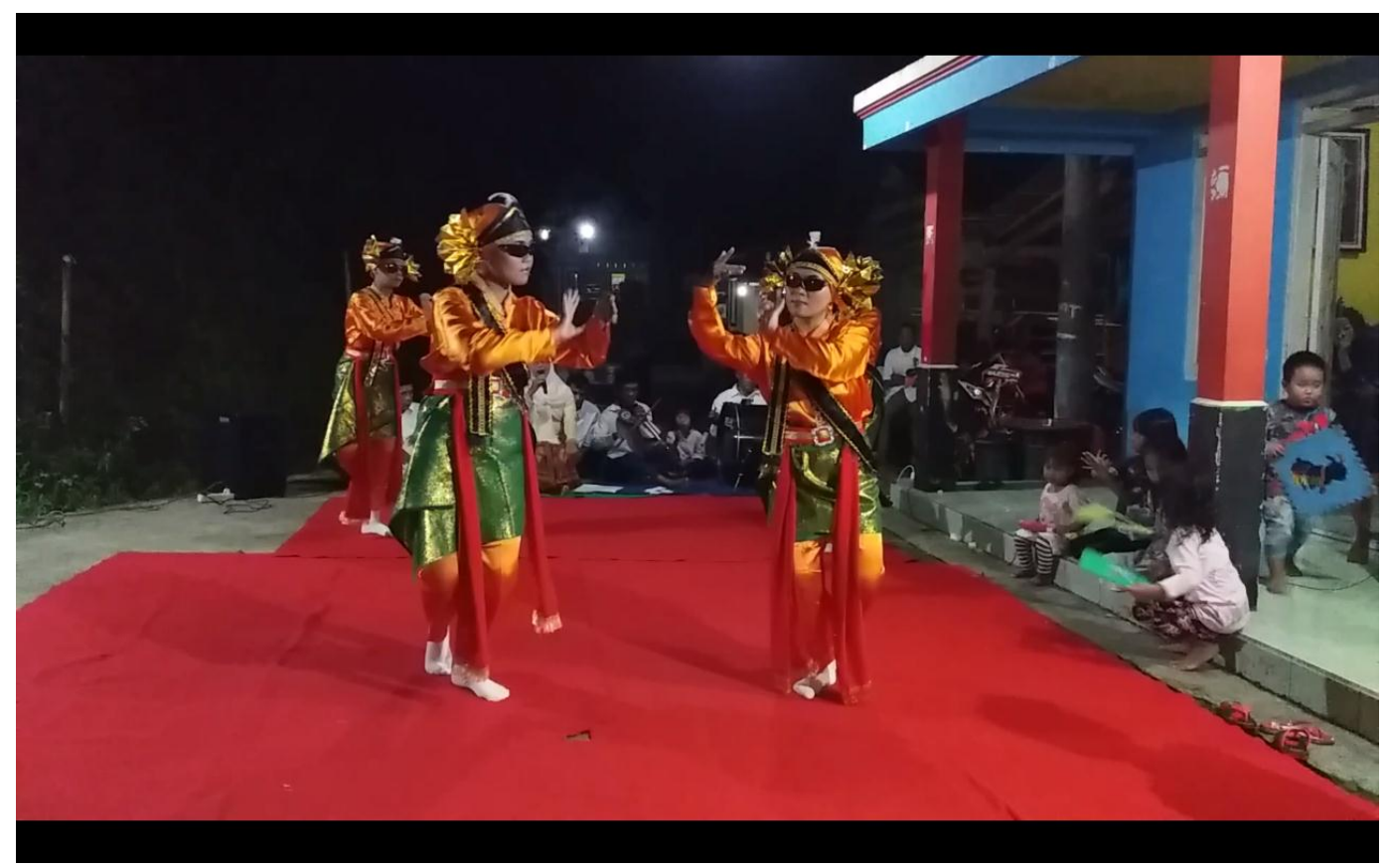

Foto 4.8. Bagian Ke Empat Tari Opak Abang: Bunga Rampai (Sumber: Dokumentasi Mawasti, 22 April 2017)

Foto 4.8. memperlihatkan 4 penari Opak Abang yang sedang melakukan gerak pada bagian Bunga Rampai. Gerak dalam bagian ini menyerupai trap jamang, lalu dilanjutkan dengan gerak yang menyerupai ngila asta. Bagian Bunga Rampai diulang sebanyak 2 kali. Para penari menyelesaikan bagian Bunga Rampai, dengan begitu usai sudah inti pertunjukan Tari Opak Abang yang terdiri atas 4 bagian, yaitu: Gayung Seribu Gayung; 2) Opak-Opak; 3) Terang Bulan; dan 4) Bunga Rampai.

\subsubsection{Akhir Pertunjukan Tari Opak Abang}

Bagian akhir pertunjukan Tari Opak Abang dapat diketahui dari gerakan Lambeyan yang dilakukan oleh 4 penari setelah menampilkan empat bagian Tari Opak Abang secara berturut-turut. Gerak Lambeyan menandakan bahwa 
pertunjukan Tari Opak Abang telah selesai. Para penari melakukan gerak Lambeyan bagian akhir, seperti dalam foto 4.9 .

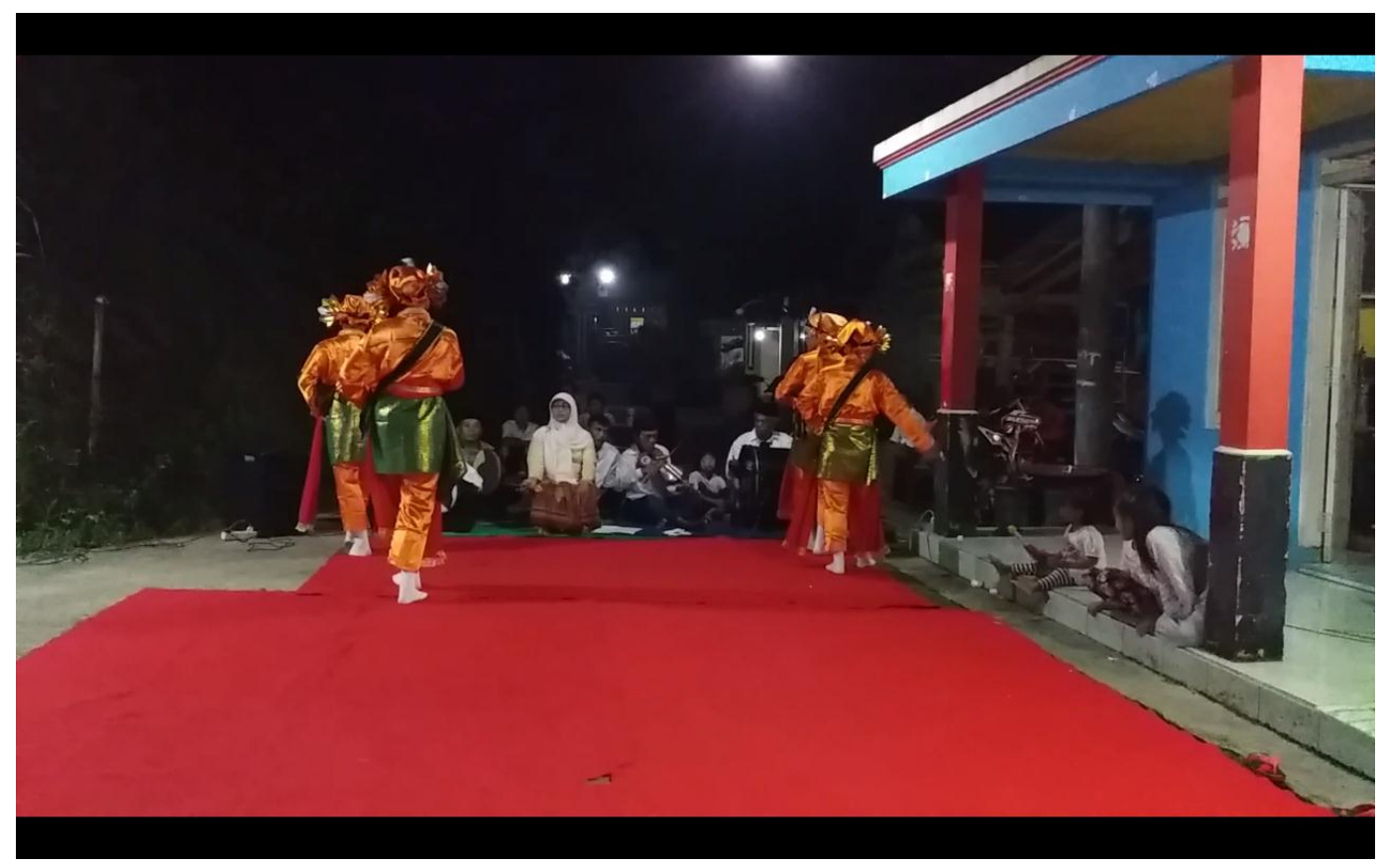

Foto 4.9. Bagian Akhir Tari Opak Abang

(Sumber: Dokumentasi Mawasti, 22 April 2017)

Pada foto 4.9. terlihat para penari Opak Abang sedang melakukan gerak Lambeyan sebagai akhir dari pertunjukan Tari Opak Abang. Akhir pertunjukan Tari Opak Abang yaitu setelah diselesaikannya 4 bagian Tari Opak Abang dari Gayung Seribu Gayung, Opak-Opak, Terang Bulan, hingga Bunga Rampai. Setelah Bunga Rampai sebagai bagian terakhir Tari Opak Abang selesai ditampilkan, 4 penari melakukan gerak Lambeyan keluar dari area pertunjukan. Pertunjukan Tari Opak Abang diakhiri dengan sambutan penutup dari Bapak Aris Salamun, dengan ini pertunjukan Tari Opak Abang telah selesai. 


\subsection{Komponen Pendukung Bentuk Pertunjukan Tari Opak Abang}

\subsubsection{Tema Tari Opak Abang}

Tari Opak Abang mempunyai tema tentang perjuangan terlihat pada gerak Tari Opak Abang yang lincah namun tetap menampilkan gerak yang gemulai. Kelincahan dan lemah gemulai pada gerak Tari Opak Abang menimbulkan kesan semangat dan ceria. Tema perjuangan juga tampak pada penggalan syair lagu Tari Opak Abang yang menyatakan kemerdekaan Indonesia dengan judul Bunga Rampai seperti yang disampaikan oleh Bapak Aris Salamun (22 Januari 2017) berikut.

"Pada zaman dahulu selain untuk menghibur, Tari Opak Abang juga digunakan untuk sarana informasi tentang kemerdekaan Indonesia dan syiar agama. Waktu itu, masyarakat banyak yang belum bisa membaca dan keterbatasan media informasi, tetapi melalui Tari Opak Abang khususnya di lirik lagu bagian Bunga Rampai, para masyarakat dahulu bisa mendapatkan informasi tentang kemerdekaan Indonesia, dan bagian Terang Bulan terdapat lirik tentang syiar agama, sehingga dalam tariannya dapat dikatakan mempunyai tema seputar kemerdekaan dan agama".

Berdasarkan hasil wawancara dengan Bapak Aris Salamun pada tanggal 22 Januari 2017, diketahui bahwa penggalan syair lagu yang berjudul Bunga Rampai bertujuan untuk menyemangati warga Desa Pasigitan dan menyebarkan informasi tentang kemerdekaan Indonesia terlihat dari kalimat "Indonesia merdeka, merdeka tetap merdeka”. Masyarakat Desa Pasigitan pada zaman dahulu, banyak yang belum bisa membaca dan sangat terbatas dalam mendapatkan informasi terbaru terutama seputar kemerdekaan Republik Indonesia. Tari Opak Abang selain bertema perjuangan, juga memiliki tema tentang keagamaan. Tema keagamaan dapat dilihat dari tata busana Tari Opak Abang yang menggunakan 
kain penutup kepala seperti kerudung, pemakaian baju lengan panjang dan celana panjang serta penggunaan kain songket sebagai penguat ciri khas melayu pada Tari Opak Abang. Tema keagamaan Tari Opak Abang juga terlihat dari syair lagunya yang berisi petuah dan nasihat-nasihat keagamaan sehingga Tari Opak Abang dijadikan sebagai syiar agama Islam. Syair lagu Tari Opak Abang yang berjudul Terang Bulan menyebutkan "Sempurnanya terserah Yang Maha Esa, Yang Maha Esa tetap tujuan kita" memiliki maksud bahwa manusia hendaknya berserah diri pada Allah SWT, karena kesempurnaan hanya milik Allah SWT. Manusia alangkah baiknya tetap menjadikan Allah SWT sebagai tujuan utama dalam hidup, yang artinya manusia harus tetap ingat kepada Allah SWT. Tuhan Yang Maha Esa dalam penggalan syair lagu Tari Opak Abang merupakan Allah SWT sebagai Tuhan para penganut agama Islam. Pada Desa Pasigitan melalui Tari Opak Abang secara langsung telah terjadi penyebaran agama Islam, sehingga penduduk Desa Pasigitan seluruhnya beragama Islam.

\subsubsection{Gerak Tari Opak Abang}

Tari Opak Abang memiliki gerak-gerak yang sederhana karena gerakan Tari Opak Abang lahir dari spontanitas masyarakat yang pada waktu itu dipelopori oleh Bapak Kusno. Berdasarkan pengamatan dari peneliti, gerak Tari Opak Abang mengadaptasi beberapa unsur gerak tari Surakarta, gerakan-gerakannya menyerupai: kebyok/kebyak sampur, ngila asta, trap jamang, dan ulap-ulap, hanya saja cara melakukan geraknya yang berbeda pada gerak dasar tari Surakarta pada umumnya, karena Tari Opak Abang merupakan tarian rakyat yang memiliki gerakan sederhana. 
Penamaan ragam-ragam gerak yang ada dalam Tari Opak Abang lebih lanjut dijelaskan oleh Bapak Aris Salamun (20 Januari 2017) berikut.

"Tidak ada nama khusus untuk ragam-ragam gerak Tari Opak Abang, karena pada saat itu sesepuh yang membuat Tari Opak Abang tidak memberikan nama-nama khusus untuk ragam-ragam geraknya. Penamaannya disesuaikan dengan urutan dan judul syair lagu. Pertama, Gayung Seribu Gayung, lalu Opak-Opak, Terang Bulan, dan Bunga Rampai”.

Berdasarkan hasil wawancara dengan Bapak Aris Salamun pada tanggal 20 Januari 2017, Tari Opak Abang sebagai tari rakyat, tentu tidak semua ragam gerak yang ada di dalam Tari Opak Abang memiliki nama-nama khusus. Peneliti mencoba untuk memberi nama pada seluruh unsur gerak yang ada di Tari Opak Abang dengan menyesuaikan dengan unsur-unsur gerak tari yang terdapat pada tari Jawa. Para pelaku pertunjukan Tari Opak Abang biasa memberi nama ragamragam gerak pada Tari Opak Abang berdasarkan dengan urutan bagian sekaligus judul syair lagu Tari Opak Abang, sehingga urutannya menjadi: 1) Gayung Seribu Gayung; 2) Opak-Opak; 3) Terang Bulan, dan 4) Bunga Rampai. Penamaan ragam gerak berdasarkan judul-judul iringan mempermudah para pelaku pertunjukan Tari Opak Abang. Peneliti telah mewawancarai seluruh pelaku pertunjukan Tari Opak Abang, dan seluruhnya mengatakan bahwa tidak mengetahui nama-nama dari ragam gerak pada Tari Opak Abang, sehingga untuk memudahkan mereka menggunakan judul-judul iringan untuk menyebut ragamragam gerak Tari Opak Abang.

Gerak Tari Opak Abang memiliki jenis gerak murni, karena dalam tiap-tiap gerakannya bermaksud menonjolkan nilai keindahan tanpa mempunyai maksud tertentu. Gerak Tari Opak Abang yang berasal dari Desa Pasigitan masih 
mempertahankan keasliannya, sehingga gerakannya sederhana. Deskripsi ragam gerak dan urutan gerak Tari Opak Abang disajikan dalam tabel 4.7.

Tabel 4.7. Deskripsi Ragam Gerak Tari Opak Abang

\begin{tabular}{|c|c|c|c|c|}
\hline NO & HITUNGAN & RAGAM & $\begin{array}{l}\text { URAIAN } \\
\text { GERAK }\end{array}$ & GAMBAR \\
\hline 1 & $\begin{array}{ll}\text { Dilakukan } & \\
\text { sebanyak } & 5 \\
\text { kali } & 8 \\
\text { hitungan } & \end{array}$ & Lambeyan & $\begin{array}{l}\text { Berjalan } \\
\text { dengan tangan } \\
\text { kiri seperti } \\
\text { malangkrik di } \\
\text { pinggang kiri, } \\
\text { sedangkan } \\
\text { tangan kanan } \\
\text { melambai ke } \\
\text { samping } \\
\text { kanan dan kiri } \\
\text { secara } \\
\text { berurutan. } \\
\text { Tolehan } \\
\text { kepala } \\
\text { berlawanan } \\
\text { dengan arah }\end{array}$ & -4 \\
\hline & & & $\begin{array}{l}\text { lambaian } \\
\text { tangan kanan. } \\
\text { Badan } \\
\text { melenggang } \\
\text { mengikuti } \\
\text { tolehan } \\
\text { kepala. }\end{array}$ & $\begin{array}{l}\text { Foto 4.10. Gerak Lambeyan } \\
\text { (Sumber: Dokumentasi } \\
\text { Mawasti, } 22 \text { April 2017) }\end{array}$ \\
\hline
\end{tabular}




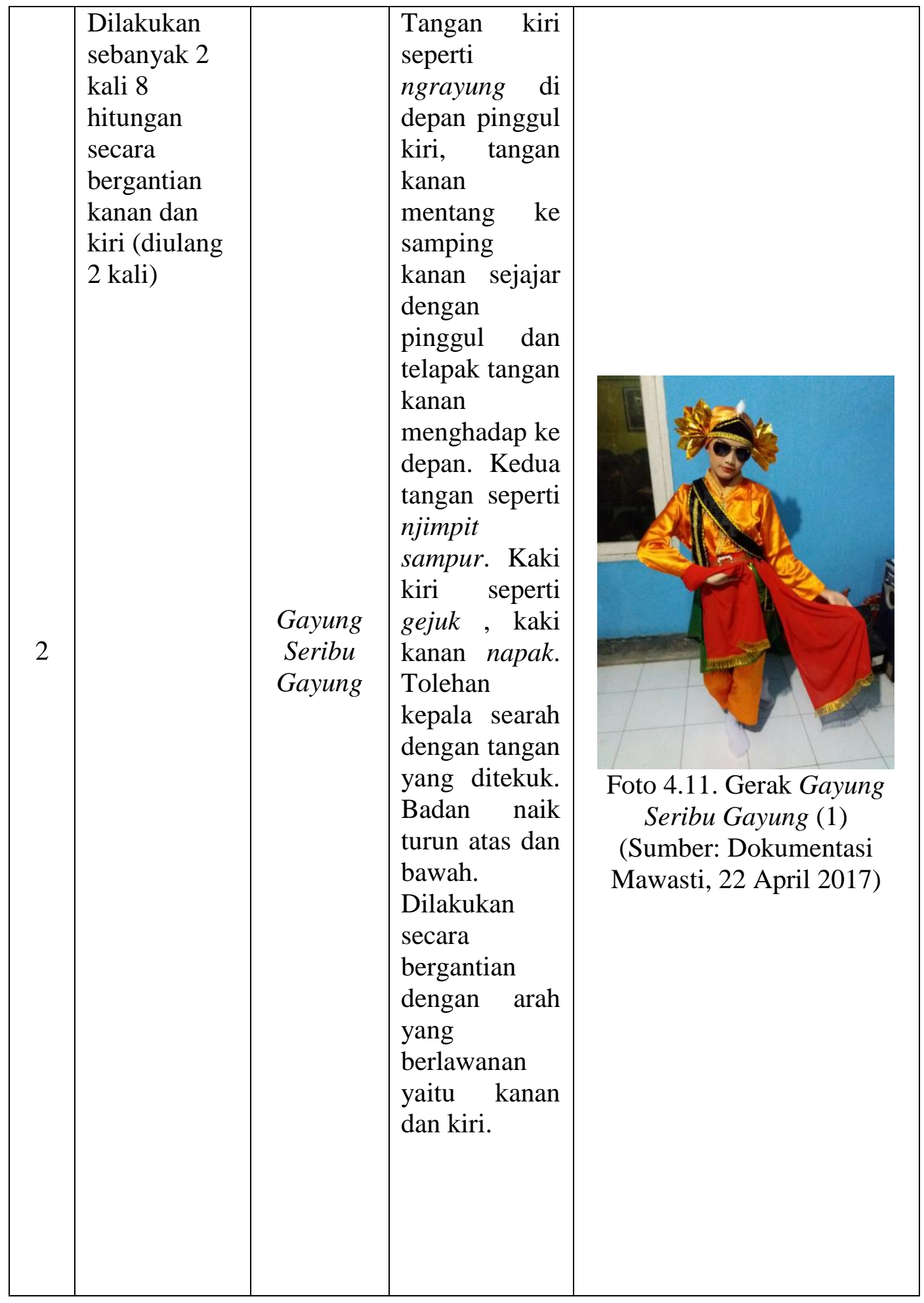




\begin{tabular}{|c|c|c|c|c|}
\hline 3 & $\begin{array}{l}\text { Dilakukan } \\
\text { sebanyak } 2 \\
\text { kali } 8 \\
\text { hitungan } \\
\text { secara } \\
\text { bergantian } \\
\text { kanan dan } \\
\text { kiri (diulang } \\
2 \text { kali) }\end{array}$ & $\begin{array}{l}\text { Gayung } \\
\text { Seribu } \\
\text { Gayung }\end{array}$ & \begin{tabular}{|lr} 
Tangan kiri \\
seperti & ukel di \\
samping \\
telinga kiri, \\
tangan kanan \\
bergerak \\
layaknya \\
seblak sampur \\
kanan. Posisi \\
tubuh tidak \\
berubah dari \\
ragam nomor \\
2. Pandangan \\
searah dengan \\
tangan yang \\
bergerak \\
seperti ukel. \\
Kedua kaki \\
berjalan ra ke \\
samping \\
kanan dan \\
kiri.
\end{tabular} & $\begin{array}{c}\text { Foto 4.12. Gerak Gayung } \\
\text { Seribu Gayung (2) } \\
\text { (Sumber: Dokumentasi } \\
\text { Mawasti, } 22 \text { April 2017) }\end{array}$ \\
\hline 4 & $\begin{array}{l}\text { Dilakukan } \\
\text { sebanyak } 2 \\
\text { kali } 8 \\
\text { hitungan }\end{array}$ & Lambeyan & $\begin{array}{l}\text { Berjalan } \\
\text { dengan tangan } \\
\text { kiri seperti } \\
\text { malangkrik di } \\
\text { pinggang kiri, } \\
\text { sedangkan } \\
\text { tangan kanan } \\
\text { melambai ke } \\
\text { samping } \\
\text { kanan dan kiri } \\
\text { secara } \\
\text { berurutan. } \\
\text { Tolehan } \\
\text { kepala } \\
\text { berlawanan } \\
\text { dengan arah } \\
\text { lambaian } \\
\text { tangan kanan. } \\
\text { Badan } \\
\text { melenggang } \\
\text { mengikuti } \\
\text { tolehan } \\
\text { kepala. }\end{array}$ & $\begin{array}{l}\text { Foto 4.13. Gerak Lambeyan } \\
\text { (Sumber: Dokumentasi } \\
\text { Mawasti, } 22 \text { April 2017) }\end{array}$ \\
\hline
\end{tabular}




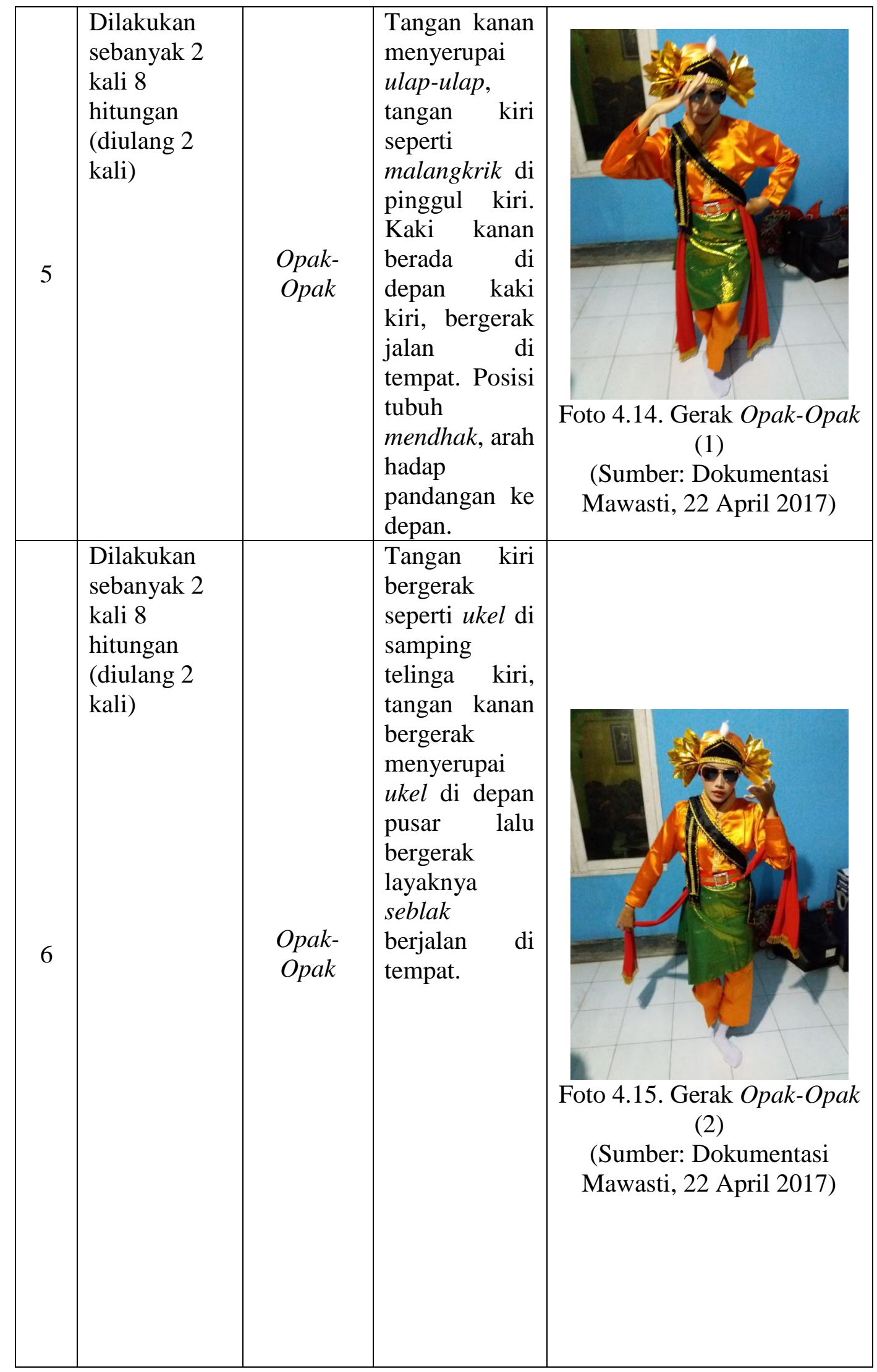




\begin{tabular}{|c|c|c|c|c|}
\hline 7 & $\begin{array}{l}\text { Dilakukan } \\
\text { sebanyak } 2 \\
\text { kali } 8 \\
\text { hitungan }\end{array}$ & Lambeyan & $\begin{array}{l}\text { Berjalan } \\
\text { dengan tangan } \\
\text { kiri seperti } \\
\text { malangkrik di } \\
\text { pinggang kiri, } \\
\text { sedangkan } \\
\text { tangan kanan } \\
\text { melambai ke } \\
\text { samping } \\
\text { kanan dan kiri } \\
\text { secara } \\
\text { berurutan. } \\
\text { Tolehan } \\
\text { kepala } \\
\text { berlawanan } \\
\text { dengan arah } \\
\text { lambaian } \\
\text { tangan kanan. } \\
\text { Badan } \\
\text { melenggang } \\
\text { mengikuti } \\
\text { tolehan } \\
\text { kepala. }\end{array}$ & $\begin{array}{l}\text { Foto 4.16. Gerak Lambeyan } \\
\text { (Sumber: Dokumentasi } \\
\text { Mawasti, } 22 \text { April 2017) }\end{array}$ \\
\hline 8 & $\begin{array}{l}\text { Dilakukan } \\
\text { sebanyak } 2 \\
\text { kali } 8 \\
\text { hitungan } \\
\text { (diulang } 2 \\
\text { kali) }\end{array}$ & $\begin{array}{c}\text { Terang } \\
\text { Bulan }\end{array}$ & 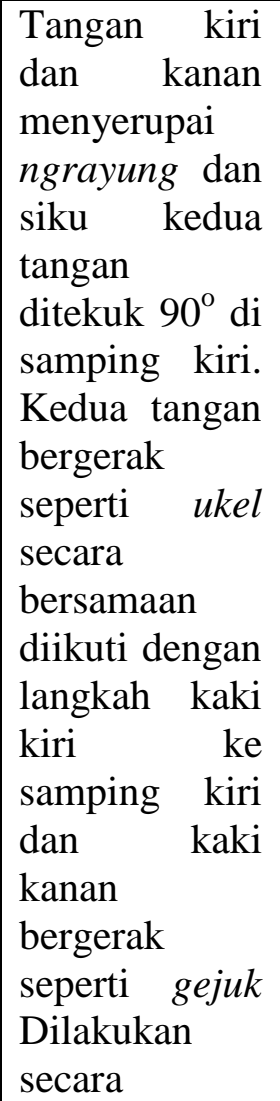 & $\begin{array}{c}\text { Foto 4.17. Gerak Terang } \\
\text { Bulan (1) } \\
\text { (Sumber: Dokumentasi } \\
\text { Mawasti, } 22 \text { April 2017) }\end{array}$ \\
\hline
\end{tabular}




\begin{tabular}{|c|c|c|c|c|}
\hline & & & $\begin{array}{l}\text { bergantian ke } \\
\text { samping kiri } \\
\text { dan kanan }\end{array}$ & \\
\hline 9 & $\begin{array}{ll}\text { Dilakukan } & \\
\text { sebanyak } & 4 \\
\text { kali } & 8 \\
\text { hitungan } & \\
\text { secara } & \\
\text { bergantian } \\
\text { kanan dan } \\
\text { kiri (diulang } \\
2 \text { kali) }\end{array}$ & $\begin{array}{c}\text { Terang } \\
\text { Bulan }\end{array}$ & $\begin{array}{l}\text { Kedua tangan } \\
\text { menyerupai } \\
\text { menthang } \\
\text { sembari jari } \\
\text { tangan seperti } \\
\text { njimpit } \\
\text { sampur. } \\
\text { Badan } \\
\text { menghadap ke } \\
\text { samping } \\
\text { kanan dan kiri } \\
\text { secara } \\
\text { bergantian, } \\
\text { dinaik- } \\
\text { turunkan ke } \\
\text { atas dan ke } \\
\text { bawah dan } \\
\text { diikuti dengan } \\
\text { ayunan kedua } \\
\text { tangan. } \\
\text { Pandangan } \\
\text { wajah searah } \\
\text { dengan posisi } \\
\text { badan. }\end{array}$ & $\begin{array}{c}\text { Foto 4.18. Gerak Terang } \\
\text { Bulan (2) } \\
\text { (Sumber: Dokumentasi } \\
\text { Mawasti, } 22 \text { April 2017) }\end{array}$ \\
\hline 10 & $\begin{array}{l}\text { Dilakukan } \\
\text { sebanyak } 2 \\
\text { kali } 8 \\
\text { hitungan }\end{array}$ & Lambeyan & $\begin{array}{l}\text { Berjalan } \\
\text { dengan tangan } \\
\text { kiri seperti } \\
\text { malangkrik di } \\
\text { pinggang kiri, } \\
\text { sedangkan } \\
\text { tangan kanan } \\
\text { melambai ke } \\
\text { samping } \\
\text { kanan dan kiri } \\
\text { secara } \\
\text { berurutan. } \\
\text { Tolehan } \\
\text { kepala } \\
\text { berlawanan } \\
\text { dengan arah } \\
\text { lambaian } \\
\text { tangan kanan. } \\
\text { Badan }\end{array}$ & $\begin{array}{l}\text { Foto 4.19. Gerak Lambeyan } \\
\text { (Sumber: Dokumentasi } \\
\text { Mawasti, } 22 \text { April 2017) }\end{array}$ \\
\hline
\end{tabular}




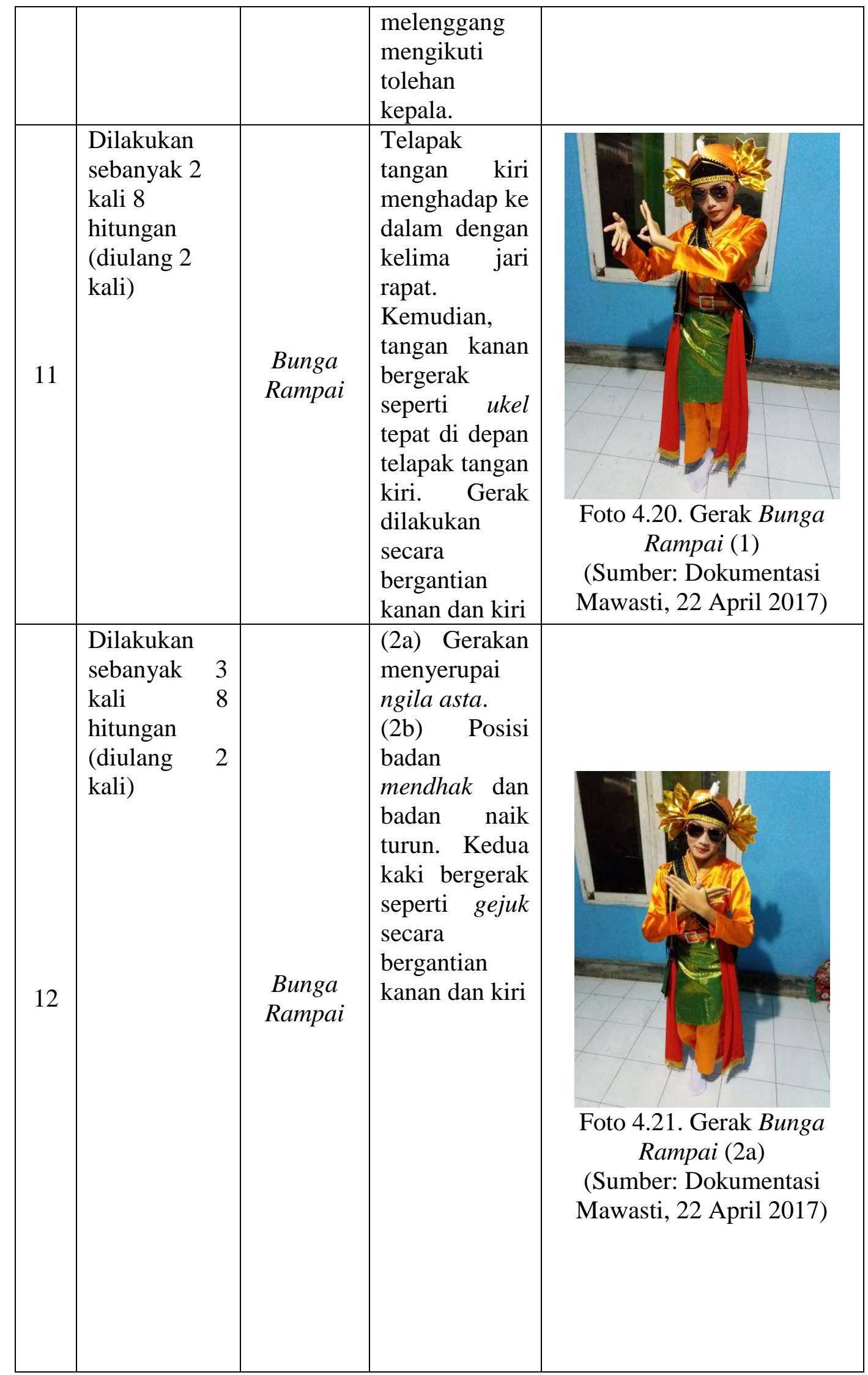




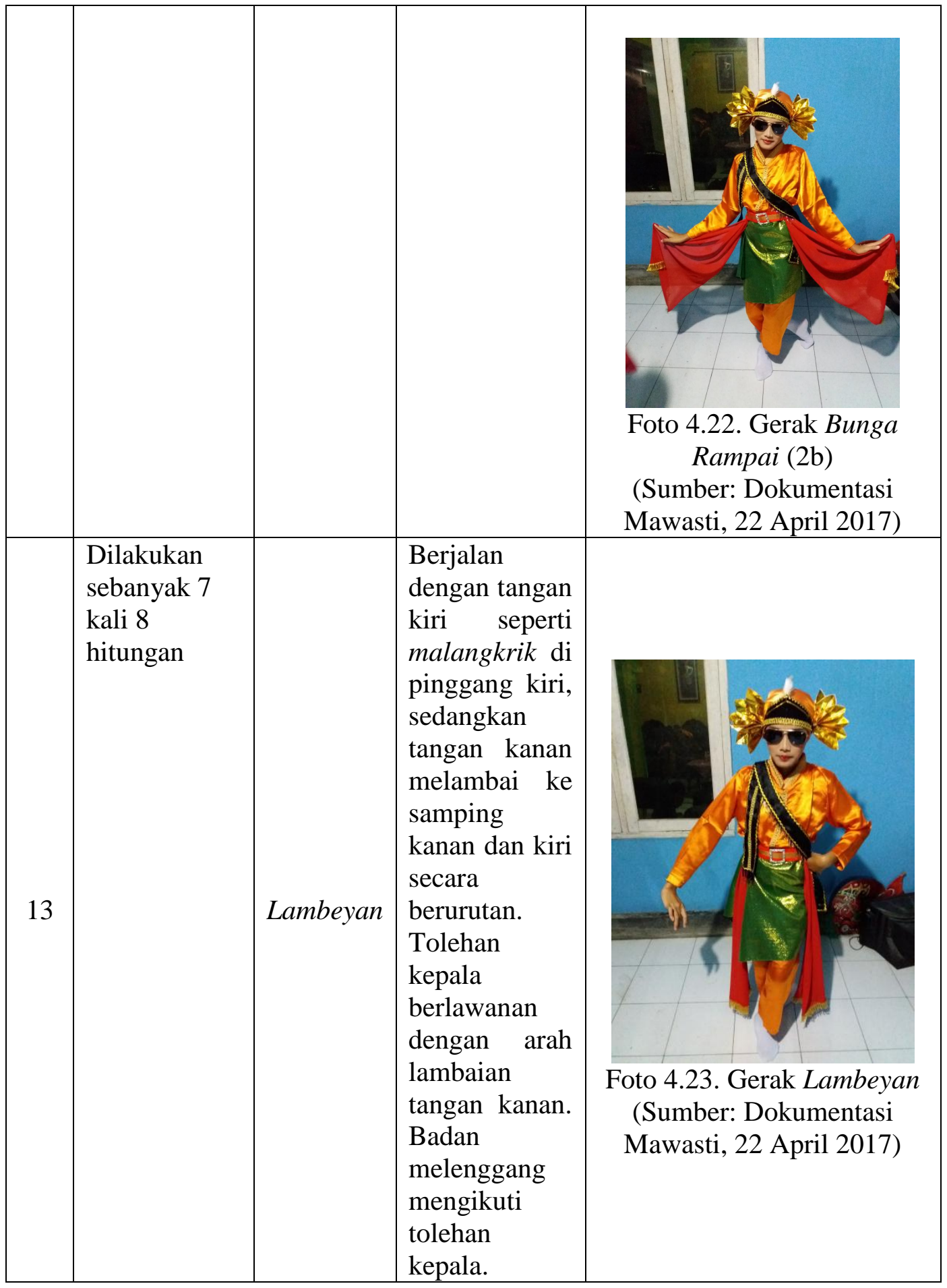

(Sumber: Mawasti, Januari 2017)

Berdasarkan deskripsi ragam gerak Tari Opak Abang yang telah dijabarkan pada tabel 4.7, diketahui bahwa Tari Opak Abang dalam pementasannya memiliki 
4 urutan, yaitu: 1) Gayung Seribu Gayung; 2) Opak-Opak; 3) Terang Bulan; dan 4) Bunga Rampai. Pada masing-masing urutan Tari Opak Abang memiliki 2 ragam gerak, dan dalam masing-masing bagian gerakannya diulang sebanyak 2 kali. Lambeyan merupakan gerak yang digunakan sebagai peralihan dari urutan Tari Opak Abang ke satu ke urutan selanjutnya atau biasa disebut dengan gerak penghubung.

\subsubsection{Ruang Gerak Tari Opak Abang}

Ruang merupakan elemen tari yang dapat menyatakan keberadaan penari. Gerak Tari Opak Abang ditinjau dari ruang dapat dibagi menjadi beberapa sub elemen, yaitu: garis; volume; arah; level; dan fokus pandang, kemudian untuk memperjelas peneliti menambahkan deskripsi berupa gambar pola lantai yang digunakan dalam pertunjukan Tari Opak Abang. Gerak Tari Opak Abang dalam pertunjukan yang diamati oleh peneliti mempunyai berbagai macam garis gerak; volume gerak; arah gerak; level gerak; fokus pandang; dan pola lantai, sehingga memunculkan variasi-variasi tersendiri pada penampilan Tari Opak Abang.

\subsection{Garis Gerak Tari Opak Abang}

Ruang dalam gerak Tari Opak Abang terdiri atas beberapa sub elemen, salah satunya yaitu garis gerak. Garis-garis yang dihasilkan oleh gerak Tari Opak Abang bermacam-macam, yaitu: garis melingkar atau lengkung; garis lurus; dan garis menyilang. Garis-garis yang terdapat dalam gerak Tari Opak Abang dapat menimbulkan kesan-kesan tertentu, yaitu: 1) kesan manis; 2) kesan istirahat; dan 3) kesan dinamis. 
Garis lengkung pada gerak Tari Opak Abang dapat dilihat pada foto 4.24. berikut.

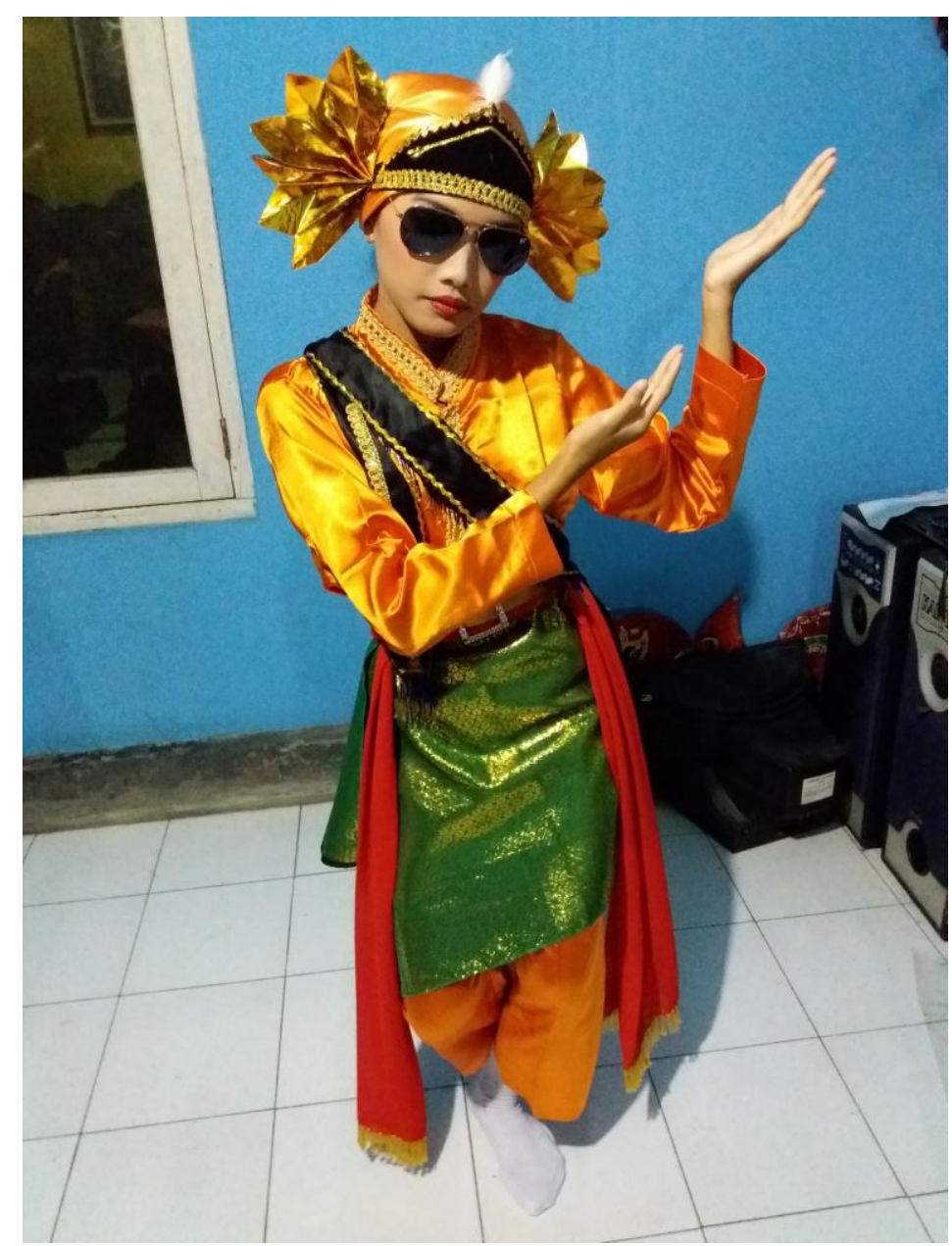

Foto 4.24. Garis Lengkung pada Gerak Tari Opak Abang (Sumber: Dokumentasi Mawasti, 22 April 2017)

Pada foto 4.24. garis gerak melingkar atau lengkung dapat diidentifikasi melalui kedua tangan yang ditekuk di samping kiri penari dan kaki kiri penari yang gejuk. Lekukan yang terdapat pada kedua tangan dan kedua kaki menimbulkan garis gerak melingkar atau lengkung. Garis melingkar atau lengkung menimbulkan kesan manis pada gerakan Tari Opak Abang. 
Garis lurus yang terdapat pada gerak Tari Opak Abang dapat dilihat pada foto 4.25. berikut.

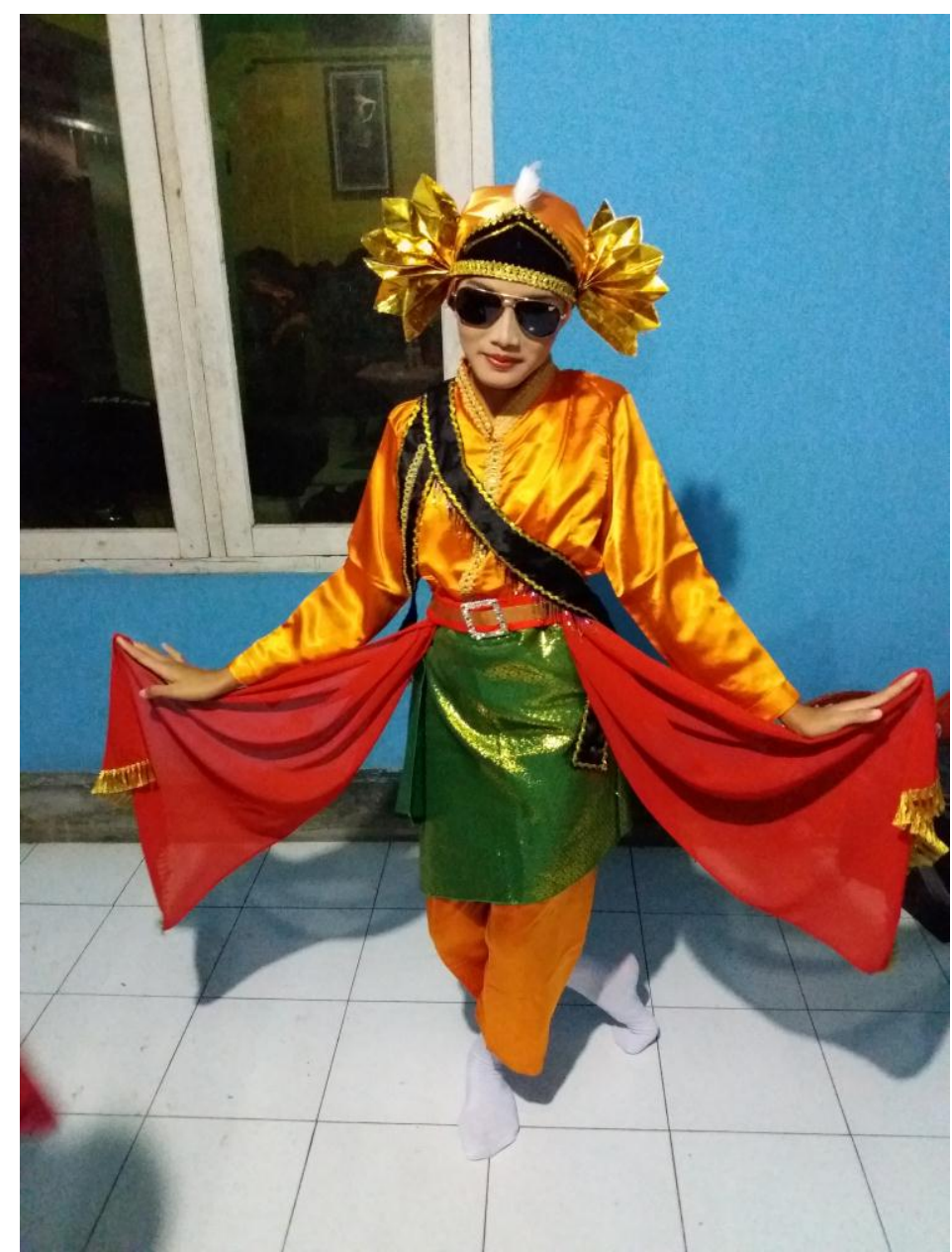

Foto 4.25. Garis Lurus pada Gerak Tari Opak Abang (Sumber: Dokumentasi Mawasti, 22 April 2017)

Garis gerak lurus yang ditunjukan pada foto 4.25. terlihat dari kedua tangan penari yang menyerupai sikap menthang ke samping kanan dan samping kiri. Tangan kanan dan kiri yang direntangkan lurus ke samping bagian bawah memperlihatkan suatu garis gerak lurus. Garis lurus menimbulkan kesan istirahat pada gerakan. 
Garis menyilang pada gerak Tari Opak Abang dapat dilihat pada foto 4.26. berikut.

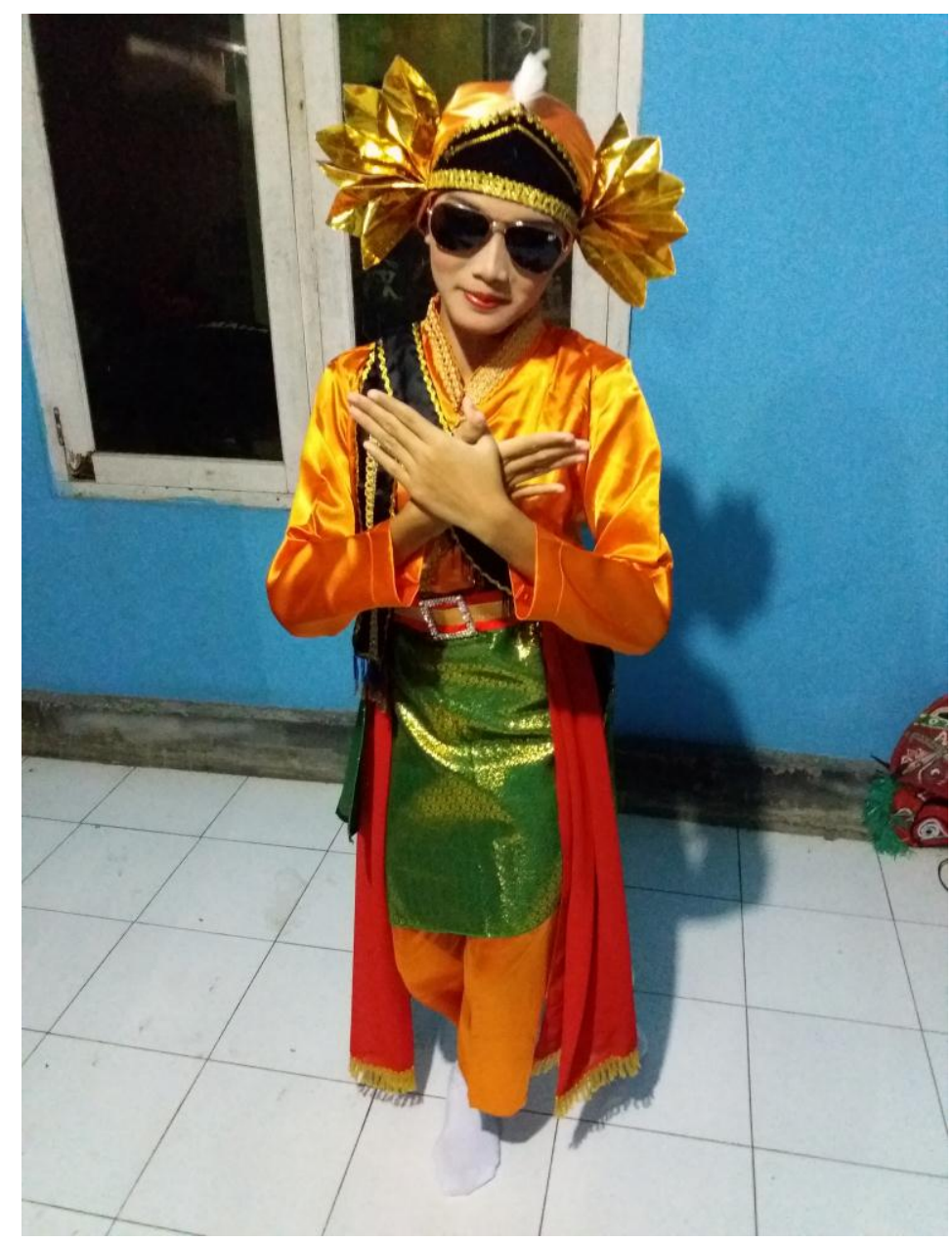

Foto 4.26. Garis Menyilang pada Gerak Tari Opak Abang (Sumber: Dokumentasi Mawasti, 22 April 2017)

Garis gerak menyilang ditunjukan pada foto 4.26. terlihat penari sedang melakukan gerak menyerupai ngila asta dengan menyilangkan telapak tangan kanan dan kiri di depan dada. Kedua tangan yang saling ditumpukkan satu sama lain menimbulkan garis gerak menyilang. Garis gerak yang menyilang dapat menimbulkan kesan dinamis pada gerakan. 


\subsection{Pola Lantai Tari Opak Abang}

Pola lantai dalam pertunjukan Tari Opak Abang pada pementasan di Desa Pasigitan dibuat lebih variatif agar terlihat lebih menarik. Pola lantai pada Tari Opak Abang sangat berkaitan dengan desain lantai pertunjukan Tari Opak Abang di area pertunjukan sebagaimana telah dijelaskan pada landasan teoretis mengenai desain lantai yaitu garis atau lintasan yang dilalui penari ketika bergerak dan berpindah dari formasi satu ke formasi selanjutnya. Penggunaan pola lantai selain berfungsi sebagai daya tarik tarian, juga sebagai cara penguasaan pentas ketika pertunjukan berlangsung. Pola-pola lantai yang digunakan dalam Tari Opak Abang disesuaikan berdasarkan jumlah penari, yaitu 4 orang.

Bentuk-bentuk pola lantai pada Tari Opak Abang bermacam-macam, diantaranya trapesium, diagonal, dan sejajar. Berikut formasi sejajar Tari Opak Abang yang ada pada foto 4.27 .

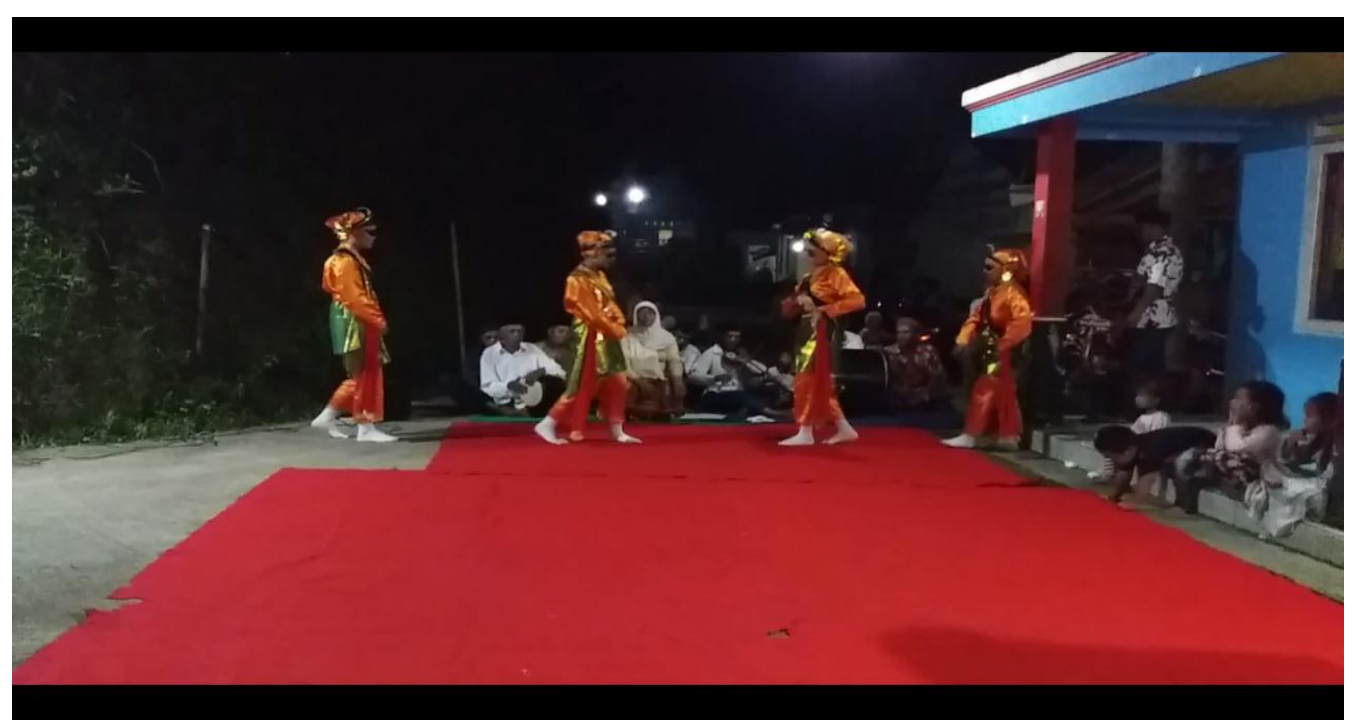

Foto 4.27. Formasi Sejajar pada Awal Tari Opak Abang

(Sumber: Dokumentasi Mawasti 22 April 2017) 
Foto 4.27. memperlihatkan formasi sejajar pada bagian awal Tari Opak Abang, yaitu gerak Lambeyan untuk memasuki area pertunjukan. Para penari secara bergantian memasuki area pertunjukan dengan dibagi menjadi 2 kelompok masing-masing berjumlah 2 orang penari. Penari yang telah memasuki area pertunjukan kemudian membentuk formasi baru sebagaimana ditunjukan pada foto 4.28 .

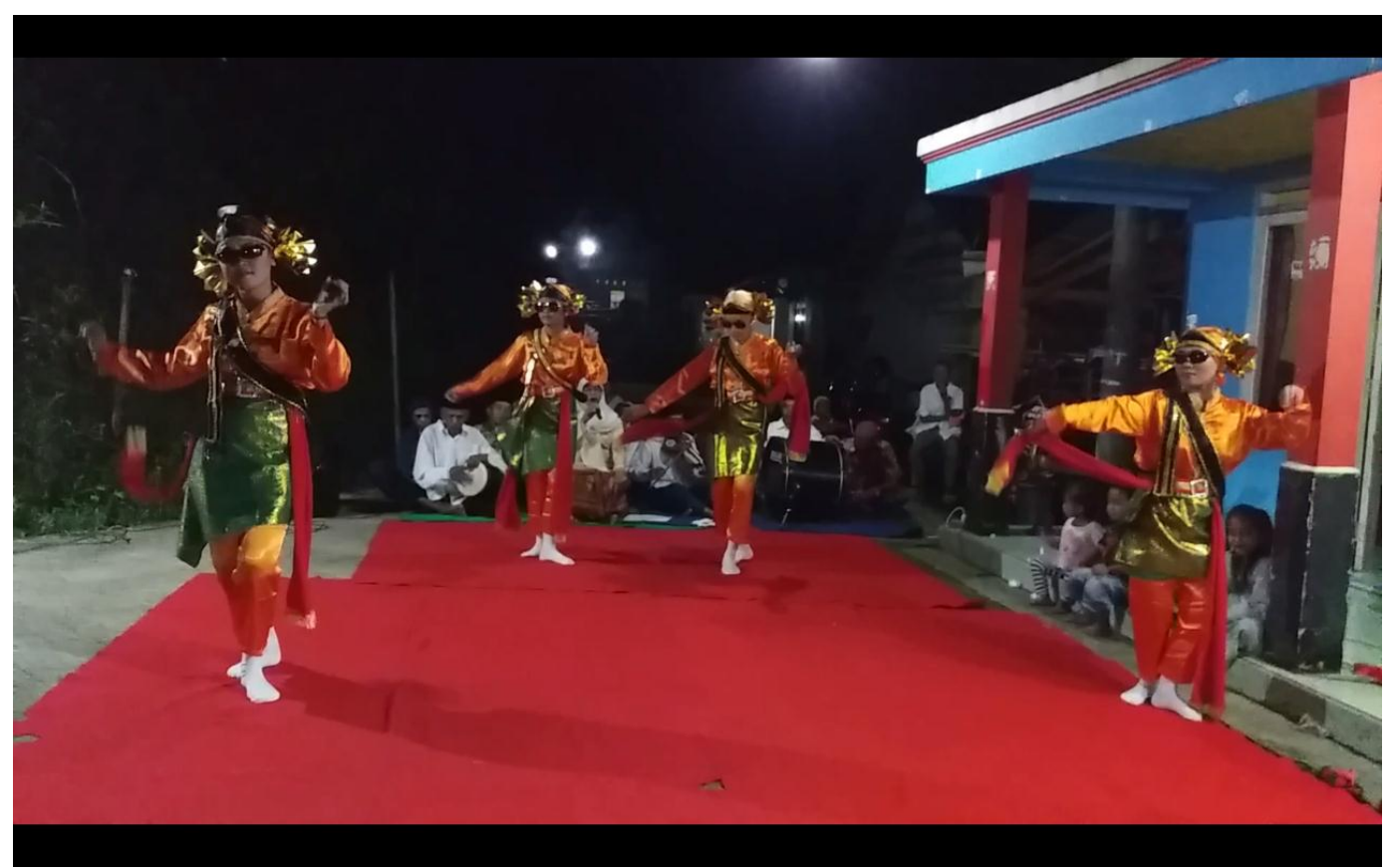

Foto 4.28. Formasi Berbentuk Trapesium pada Bagian Gayung Seribu Gayung (Sumber: Dokumentasi Mawasti, 22 April 2017)

Berdasarkan foto 4.28. formasi yang digunakan pada Tari Opak Abang bagian Gayung Seribu Gayung ialah trapesium. Formasi trapesium dapat diidentifikasi dari 2 orang penari bagian depan yang posisinya lebih melebar ke samping kanan dan kiri dari 2 orang penari paling belakang sehingga bentuk yang terlihat yaitu 
trapesium. Pada bagian berikutnya, Opak-Opak, para penari berpindah formasi menjadi seperti pada foto 4.29 .

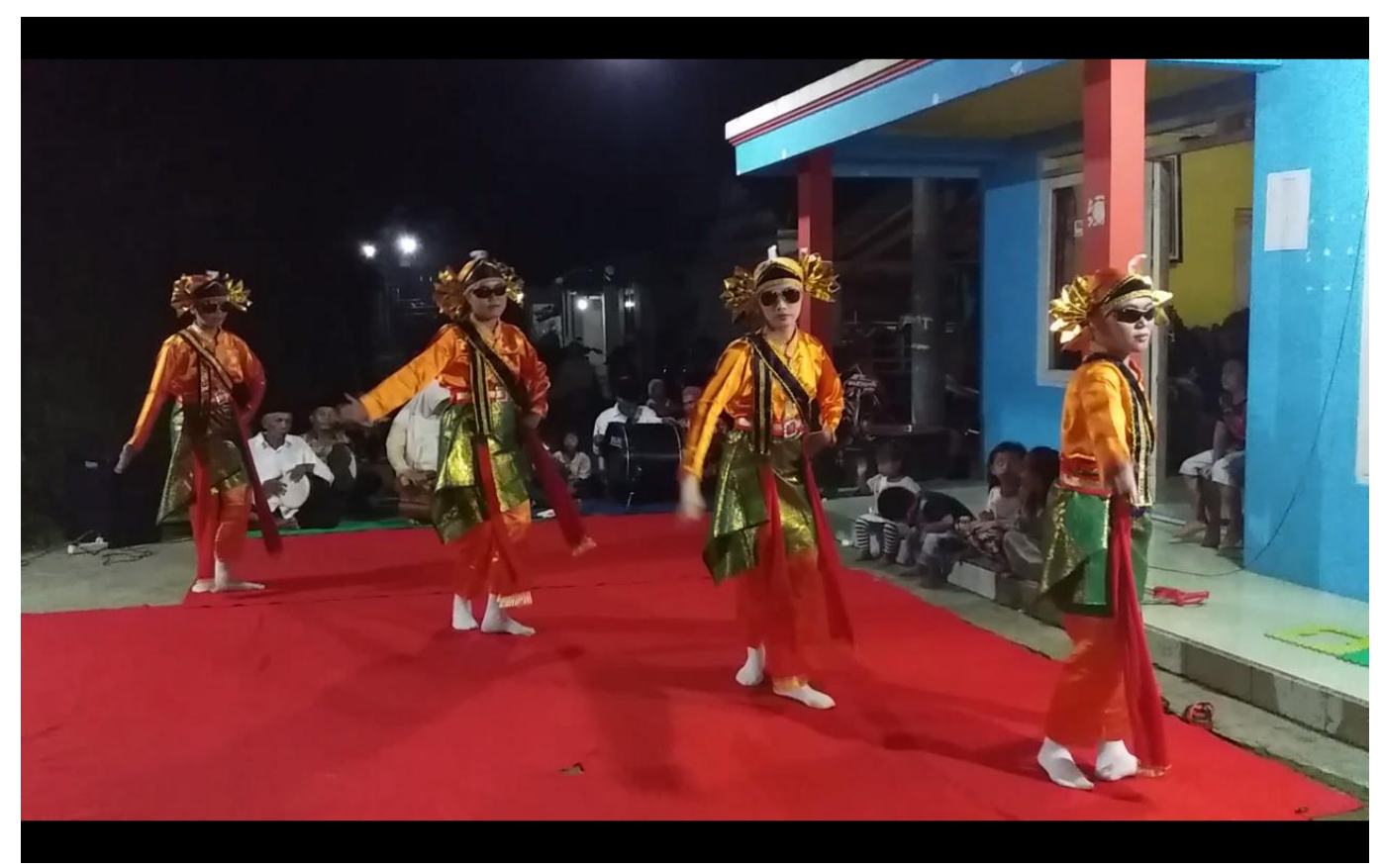

Foto 4.29. Formasi Diagonal pada Bagian Opak-Opak

(Sumber: Dokumentasi Mawasti, 22 April 2017)

Foto 4.29. memperlihatkan formasi diagonal (miring) Tari Opak Abang pada bagian Opak-Opak. Formasi diagonal dapat terbentuk dari posisi para penari yang menghadap serong kiri depan seperti pada foto 4.29. Formasi diagonal membuat fokus pandang gerak dan penari menuju ke arah serong kiri depan. Formasi diagonal digunakan untuk menambah tingkat variasi dalam permainan pola lantai pertunjukan Tari Opak Abang, karena apabila arah hadapnya monoton maka akan terlihat membosankan. Usai formasi diagonal pada bagian Opak-Opak, selanjutnya para penari Opak Abang berpindah tempat sambil melakukan gerak 
Lambeyan, hingga akhirnya mencapai posisi penari masing-masing membentuk seperti pada foto 4.30 .

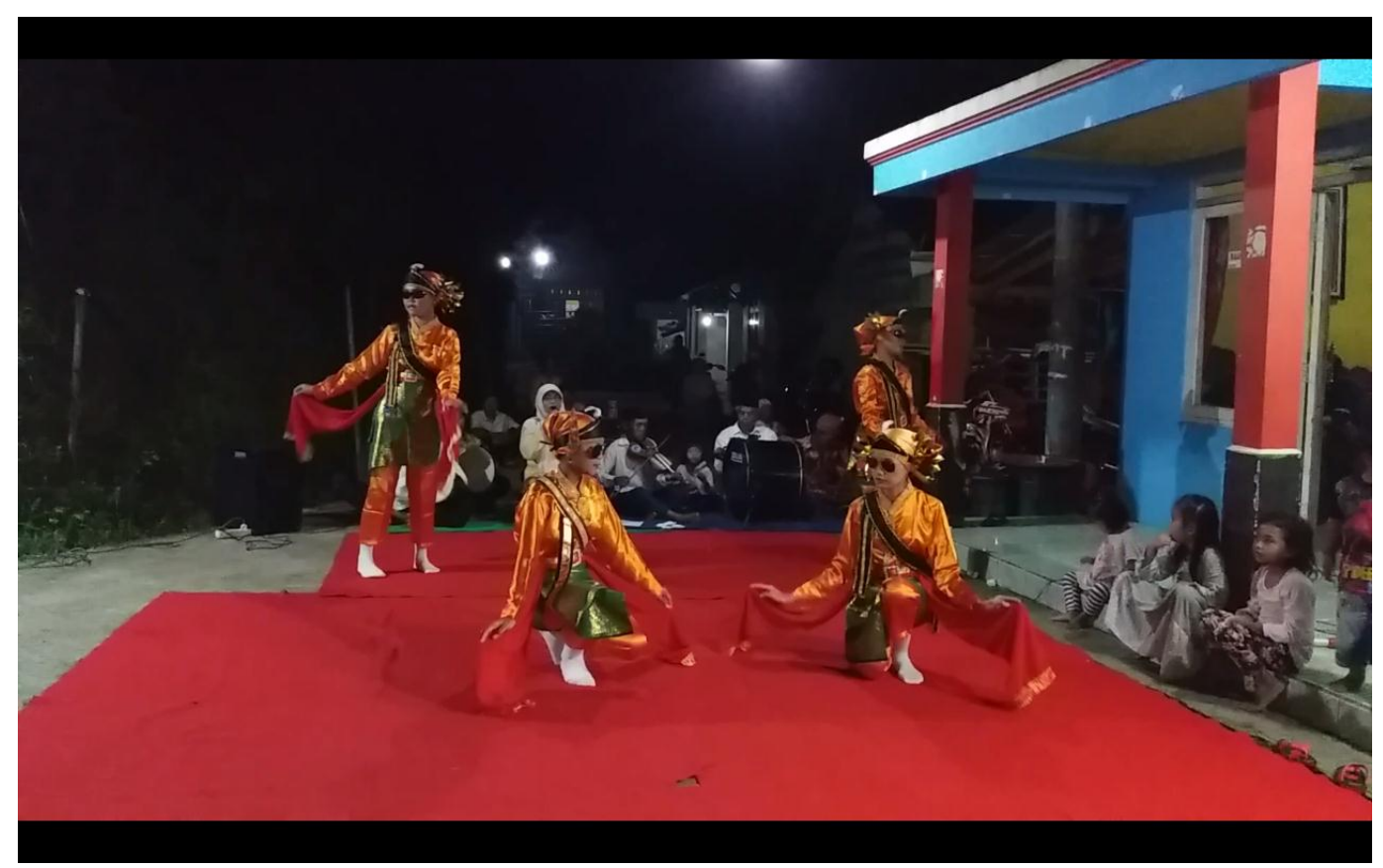

Foto 4.30. Formasi Berbentuk Trapesium pada Bagian Terang Bulan (Sumber: Dokumentasi Mawasti, 22 April 2017)

Foto 4.30. menunjukan formasi berbentuk trapesium pada bagian Terang Bulan. Formasi trapesium yang digunakan pada bagian Terang Bulan sama seperti yang digunakan pada bagian Gayung Seribu Gayung, hanya saja pada bagian Terang Bulan diberi tambahan permainan level gerak rendah dan level gerak tinggi seperti yang terlihat pada foto 4.30 , selain permainan level, pada bagian ini juga disertai dengan permainan arah gerak yang berlawanan sehingga terdapat efek buka dan tutup pada gerak keseluruhan penari. Formasi trapesium masih dilanjutkan sampai dengan bagian Bunga Rampai, akan tetapi sebelum memasuki 
bagian Bunga Rampai, para penari terlebih dahulu melakukan gerak Lambeyan sambil bertukar posisi seperti pada foto 4.31 .

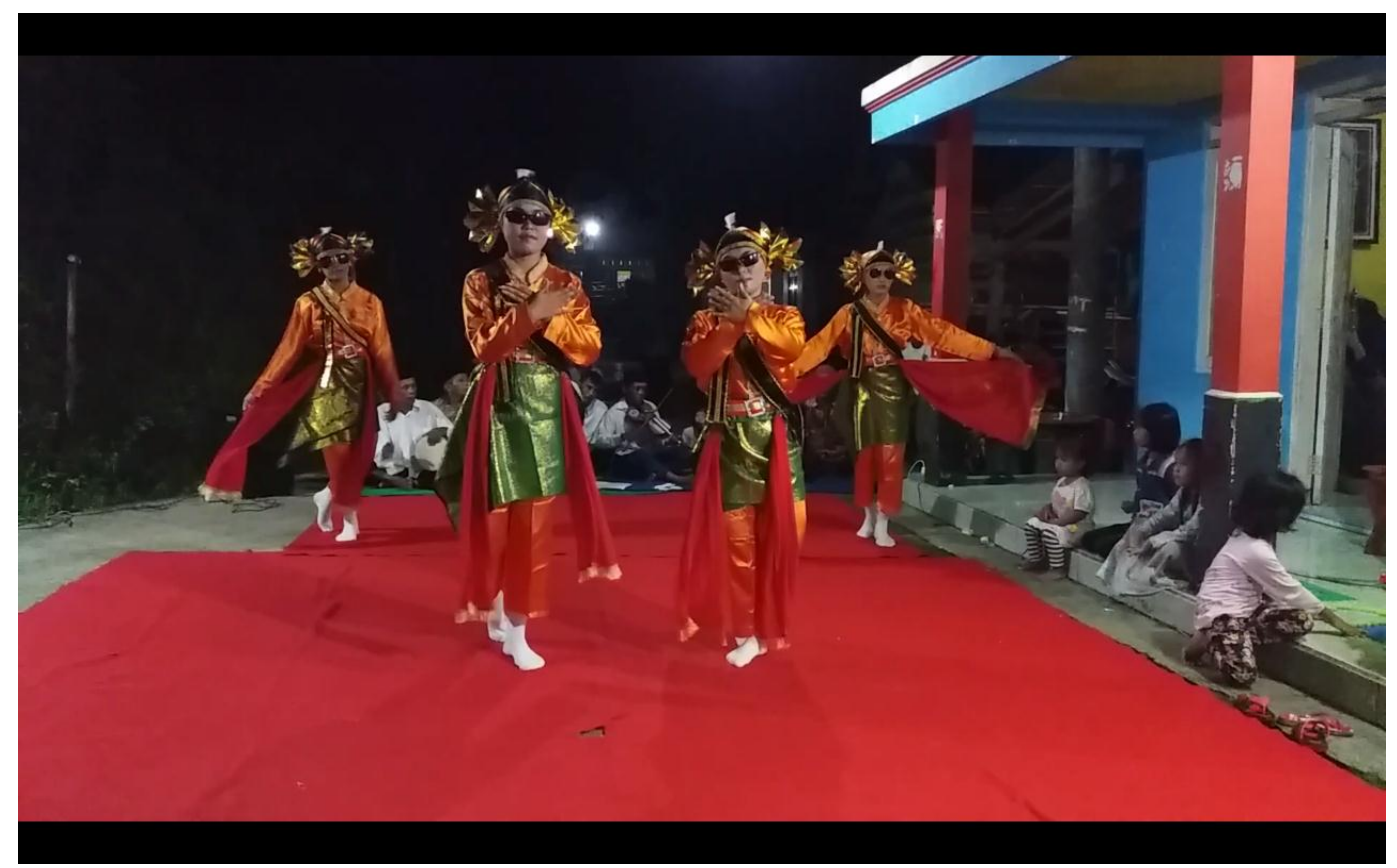

Foto 4.31. Formasi Berbentuk Trapesium pada Bagian Bunga Rampai (Sumber: Dokumentasi Mawasti, 22 April 2017)

Pada foto 4.31. terlihat penggunaan kembali dari formasi trapesium di bagian Bunga Rampai. Bagian Bunga Rampai selain menggunakan formasi trapesium juga menambahkan variasi gerak dengan arah yang berlawanan sebagaimana yang terlihat pada foto 4.31. hingga menimbulkan efek buka dan tutup pada formasi gerak Tari Opak Abang. Penggunaan variasi gerak berlawanan dapat membuat penonton tidak merasa bosan dengan formasi-formasi yang digunakan dalam Tari Opak Abang. Pada akhir Tari Opak Abang, para penari melakukan gerak Lambeyan kemudian berubah formasi menjadi sejajar seperti di bagian awal Tari Opak Abang, akan tetapi formasi sejajar pada bagian akhir posisinya berada lebih 
ke depan dari pada formasi sejajar di bagian awal yang posisinya berada lebih ke belakang dekat dengan pemusik. Berikut formasi sejajar Tari Opak Abang seperti pada foto 4.32 .

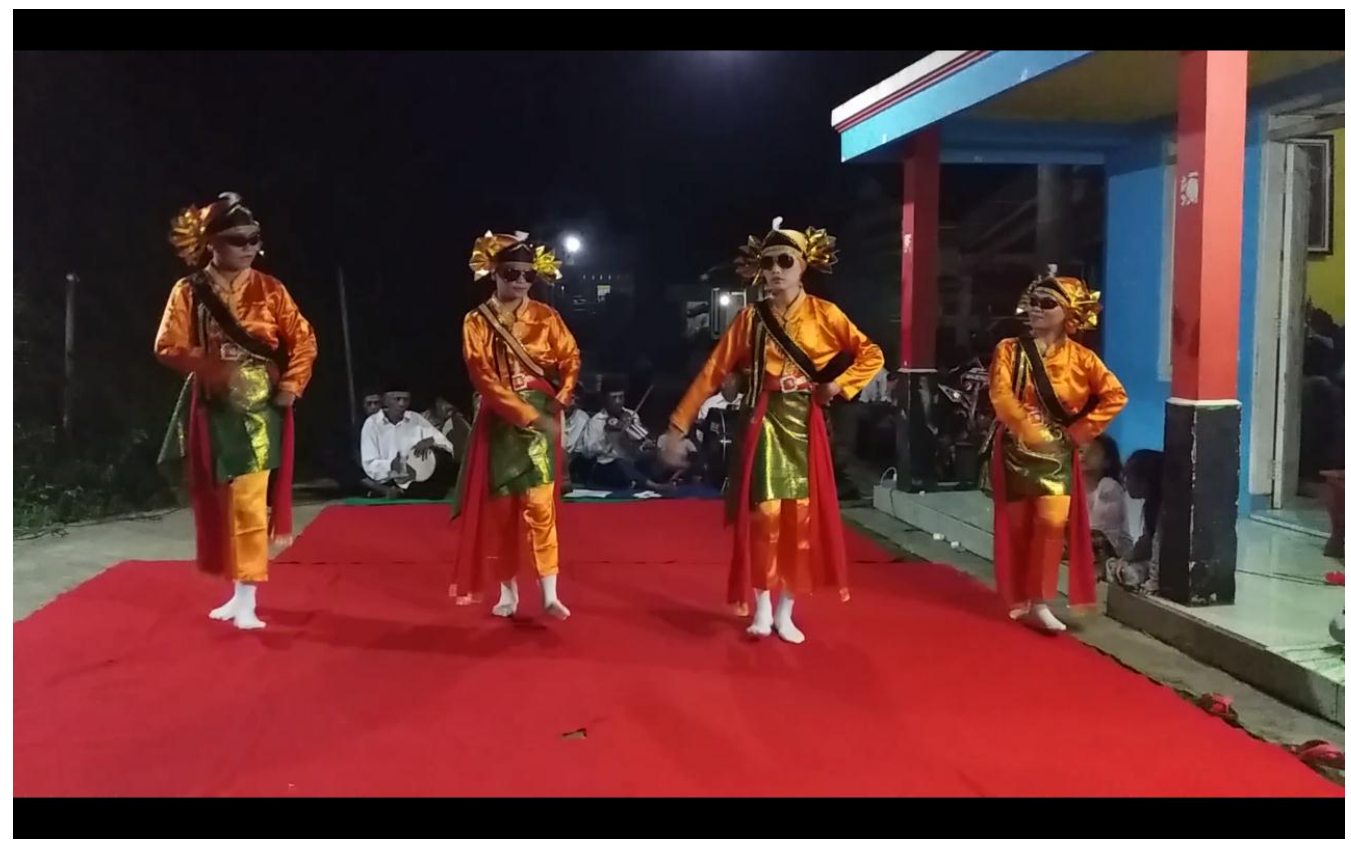

Foto 4.32. Formasi Sejajar pada Akhir Tari Opak Abang

(Sumber: Dokumentasi Mawasti, 22 April 2017)

Berdasarkan foto 4.32. dapat diketahui bahwa Tari Opak Abang kembali menggunakan formasi sejajar seperti pada bagian awal ketika penari Opak Abang memasuki area pertunjukan. Formasi sejajar digunakan sebagai awalan dan akhiran pertunjukan Tari Opak Abang. Formasi sejajar terlihat dari para penari yang berdiri secara berdampingan dengan arah hadap yang sama.

\subsection{Volume Gerak Tari Opak Abang}

Volume yang dihasilkan oleh gerak-gerak Tari Opak Abang bervariasi, ada yang volume kecil, sedang dan besar. Variasi gerak dalam Tari Opak Abang dapat menimbulkan ketertarikan penonton sehingga sajian Tari Opak Abang tidak 
membosankan. Volume gerak dalam Tari Opak Abang berkaitan erat dengan ruang gerak penari. Volume gerak kecil berarti gerak tari yang mempunyai volume dan penggunaan ruang gerak yang kecil, volume gerak sedang artinya gerak yang mempunyai volume dan penggunaan gerak yang sedang, dan volume gerak besar dapat dikatakan bahwa gerak yang memiliki volume dan membutuhkan ruang gerak yang besar.

Berikut gerak Tari Opak Abang yang memiliki volume kecil seperti pada foto 4.33 .

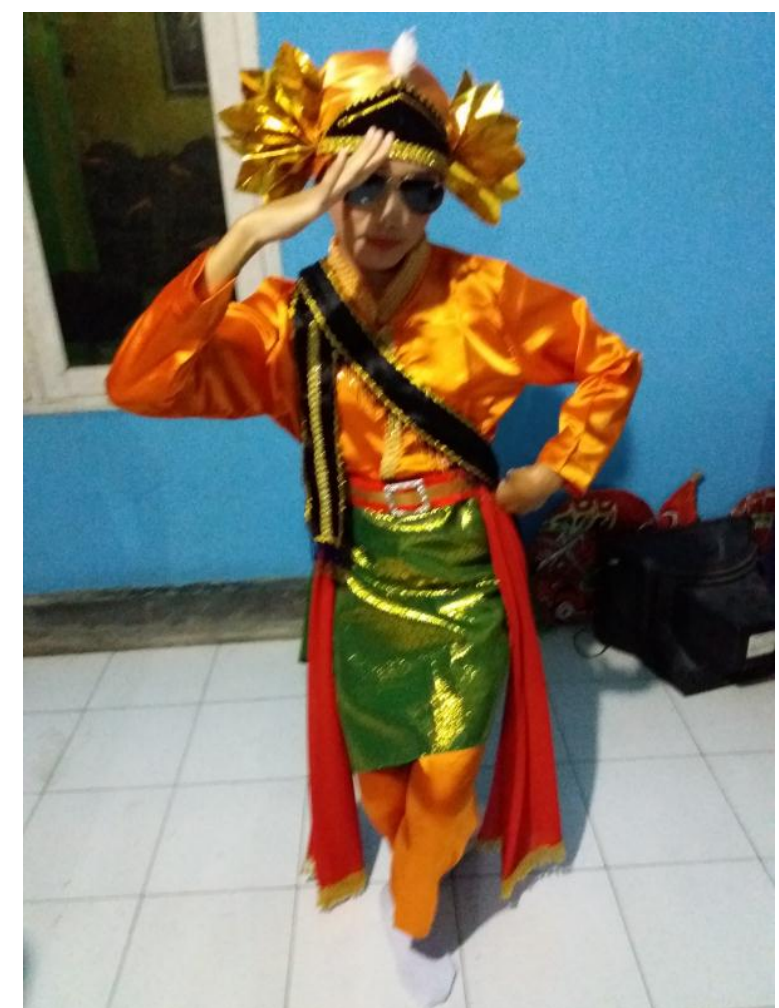

Foto 4.33. Gerak Tari Opak Abang dengan Volume Kecil (Sumber: Dokumentasi Mawasti, 22 April 2017)

Pada foto 4.33. merupakan peragaan menyerupai gerak ulap-ulap Tari Opak Abang. Gerak menyerupai ulap-ulap termasuk kategori gerak volume kecil karena 
gerak yang dilakukan tidak memerlukan ruang gerak yang besar, selain itu gerak dalam foto 4.33 dilakukan tanpa berpindah tempat, sedangkan gerak Tari Opak Abang dengan volume sedang dapat dilihat pada foto 4.34

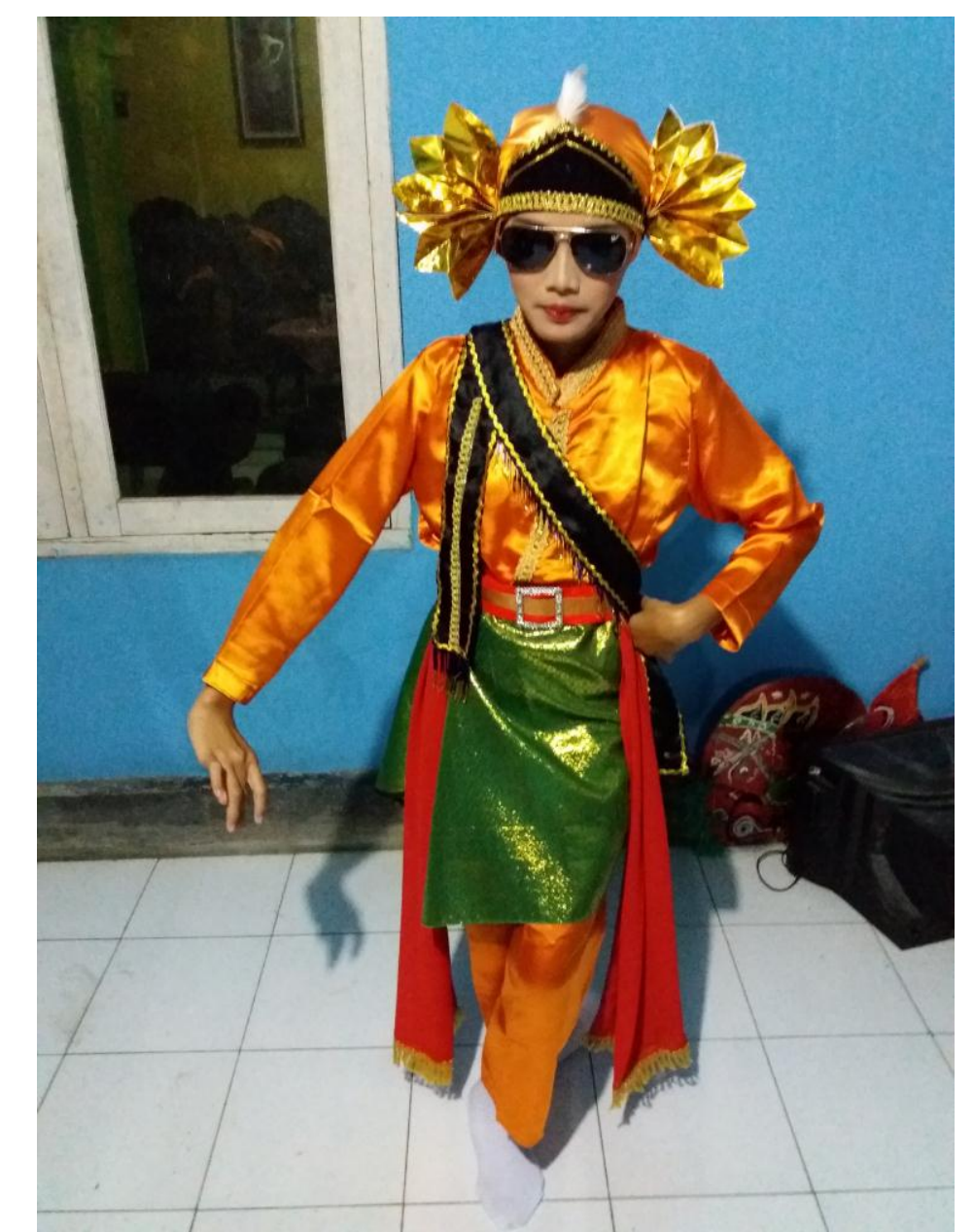

Foto 4.34. Gerak Tari Opak Abang dengan Volume Sedang (Sumber: Dokumentasi Mawasti, 22 April 2017)

Gerak dalam foto 4.34. merupakan gerak dengan volume sedang, karena untuk bergerak Lambeyan seperti pada foto 4.34. memerlukan ruang gerak yang cukup luas. Gerak dengan volume sedang seperti pada foto 4.34. cenderung 
membutuhkan ruang gerak yang tidak terlalu besar, karena gerak yang ditimbulkan berkapasitas sedang.

Gerak Tari Opak Abang dengan volume besar dapat dilihat pada foto 4.35.

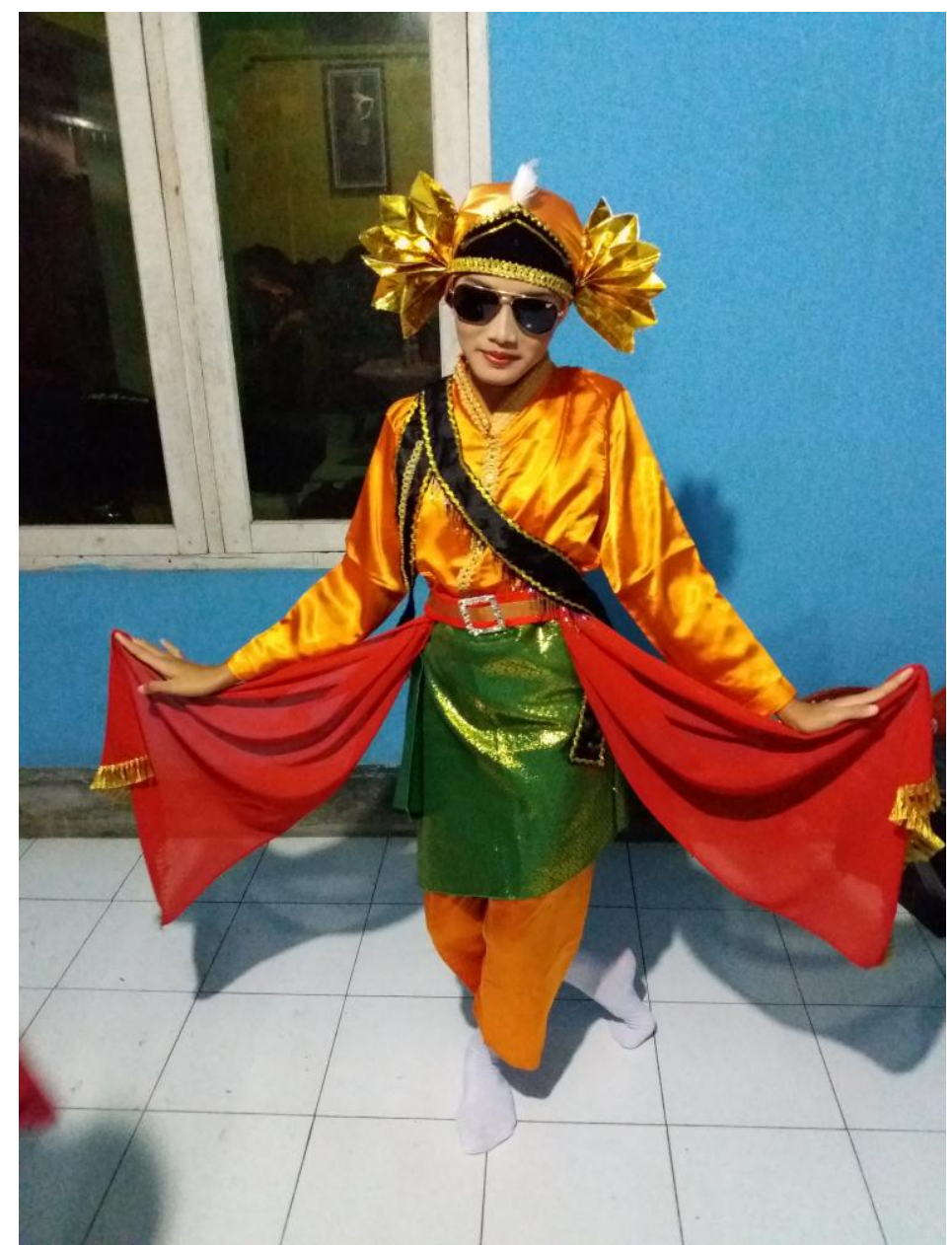

Foto 4.35. Gerak Tari Opak Abang dengan Volume Besar (Sumber: Dokumentasi Mawasti, 22 April 2017)

Foto 4.35. adalah peragaan gerak dengan volume gerak yang besar. Terlihat dari kedua tangan seperti menthang ke kanan dan kiri sehingga memerlukan ruang gerak yang luas. Kedua tangan penari yang merentang ke samping kanan dan 
samping kiri seperti pada foto 4.35. membuat ruang gerak yang dibutuhkan penari menjadi besar.

\subsection{Arah Gerak Tari Opak Abang}

Arah yang digunakan dalam Tari Opak Abang bermacam-macam, yaitu: depan, belakang, samping kanan, samping kiri dan serong kanan. Penggunaan arah yang berbagai macam bertujuan untuk memberi sentuhan tersendiri pada pertunjukan tari agar tidak membosankan.

Berikut adalah arah gerak ke samping kanan dan samping kiri dalam Tari Opak Abang yang disajikan dalam foto 4.36.

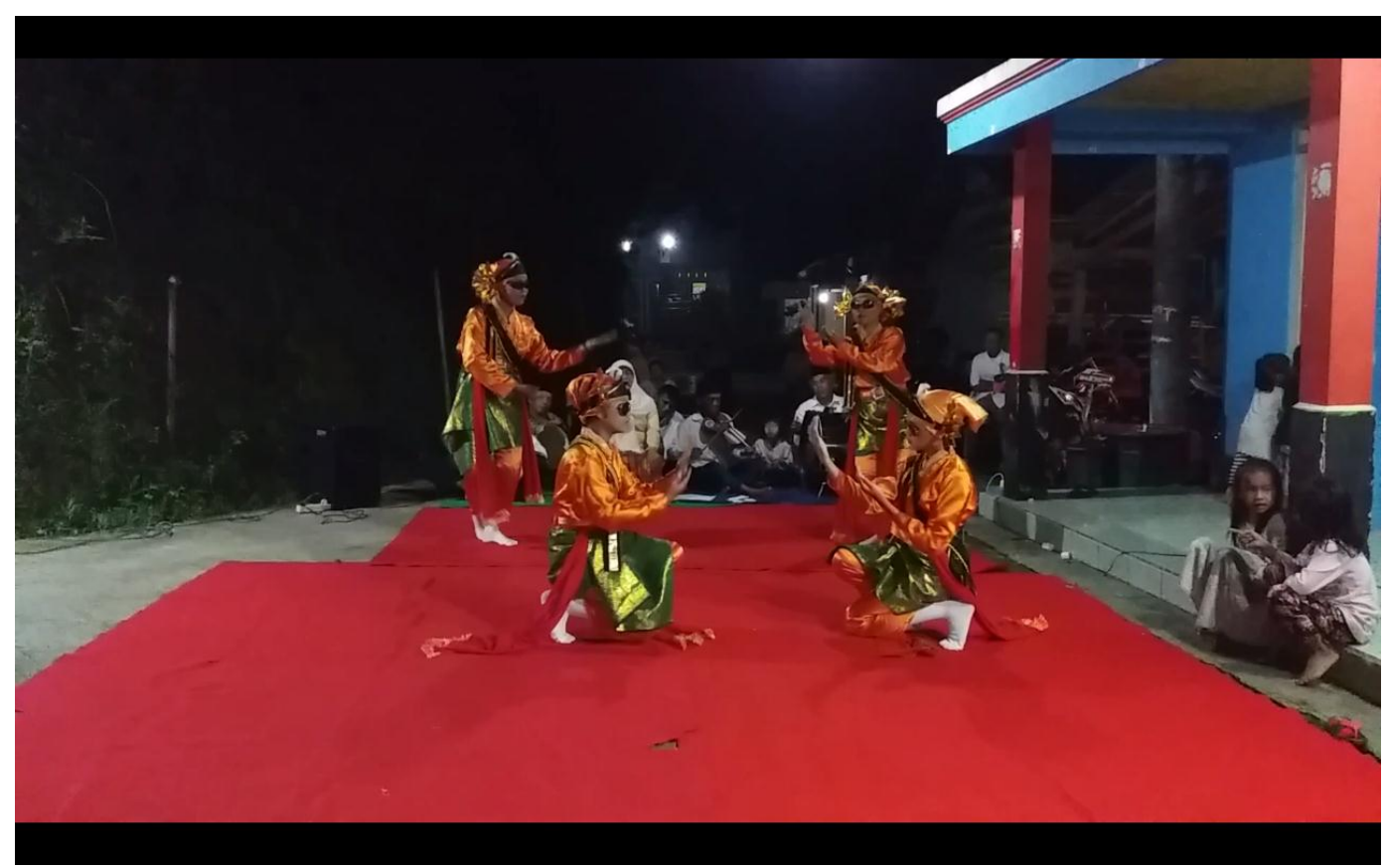

Foto 4.36. Arah Gerak Tari Opak Abang ke Samping Kanan dan Samping Kiri (Sumber: Dokumentasi Mawasti, 22 April 2017)

Foto 4.36. memperlihatkan arah gerak Tari Opak Abang ke samping kanan dan kiri secara bersamaan. Gerak yang dilakukan penari pada foto 4.22 memiliki 
arah hadap yang berubah-ubah, yaitu kanan dan kiri. Arah hadap penari secara langsung mengikuti arah gerak yang menghadap ke kanan dan ke kiri secara bergantian. Pada foto 4.36, gerakannya menggunakan variasi arah hadap yang berlawanan.

Arah gerak Tari Opak Abang ke depan dapat dijumpai seperti yang ada dalam foto 4.37 .

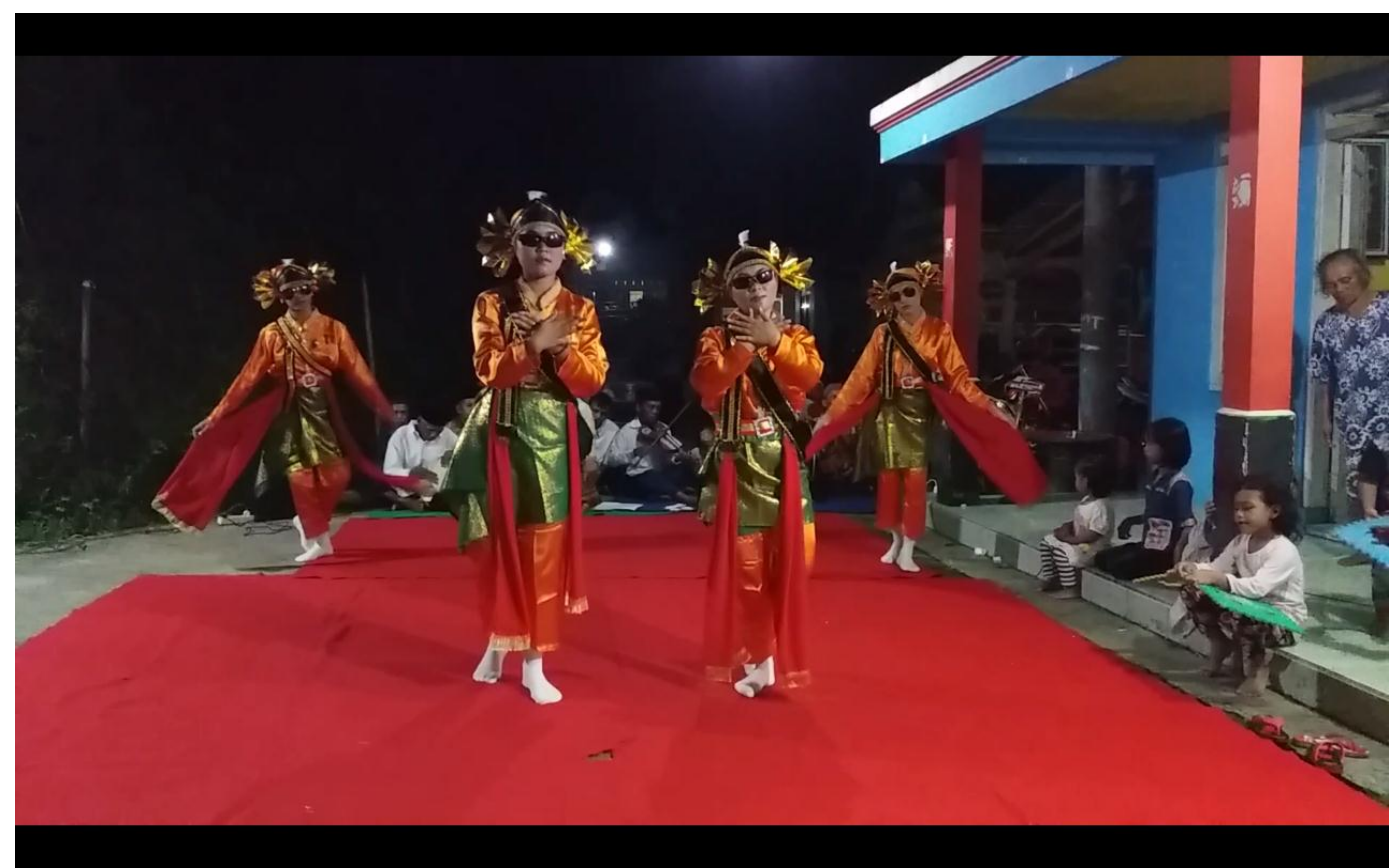

Foto 4.37. Arah Gerak Tari Opak Abang ke Depan

(Sumber: Dokumentasi Mawasti, 22 April 2017)

Foto 4.37. menunjukan arah gerak Tari Opak Abang ke depan. Walaupun gerak yang dilakukan penari dengan cara bergeser ke samping kanan dan kiri, akan tetapi arah hadap penari tetap menuju ke depan. Pada bagian ini, 2 penari depan dengan 2 penari belakang memiliki arah gerak yang saling berlawanan, sehingga menimbulkan efek buka dan tutup pada tarian. Efek buka dan tutup pada 
gerak penari dapat menambah daya tarik penonton, sehingga penampilan Tari Opak Abang tidak membosankan.

Berikut arah gerak Tari Opak Abang ke belakang dapat dilihat pada foto 4.38.

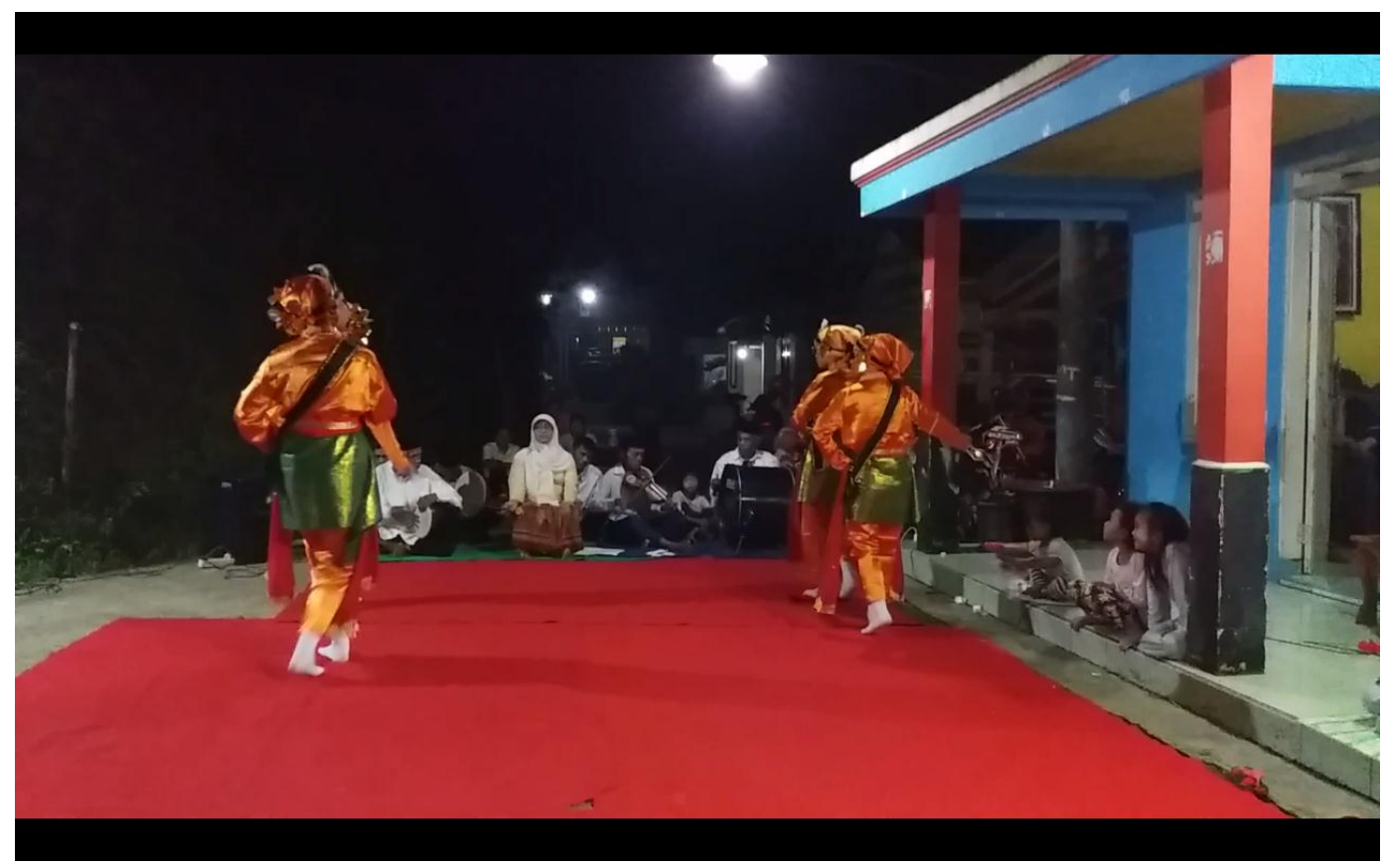

Foto 4.38. Arah Gerak Tari Opak Abang ke Belakang

(Sumber: Dokumentasi Mawasti, 22 April 2017)

Foto 4.38. berkebalikan arahnya dengan foto 4.37, arah gerak yang ditunjukan yaitu menuju belakang begitu pula arah hadap penari juga ke belakang. Pada bagian ini, penari tidak serta merta menghadap ke belakang dengan waktu yang lama, namun dilanjut dengan berjalan mengitari area pertunjukan sehingga arah hadap penari menjadi ke segala penjuru. Gerak mengitari area pertunjukan selain sebagai upaya penguasaan pentas, juga sebagai penambah variasi penampilan Tari Opak Abang agar semakin menarik. 
Arah gerak Tari Opak Abang serong ke kiri depan dapat dilihat pada foto 4.39 .

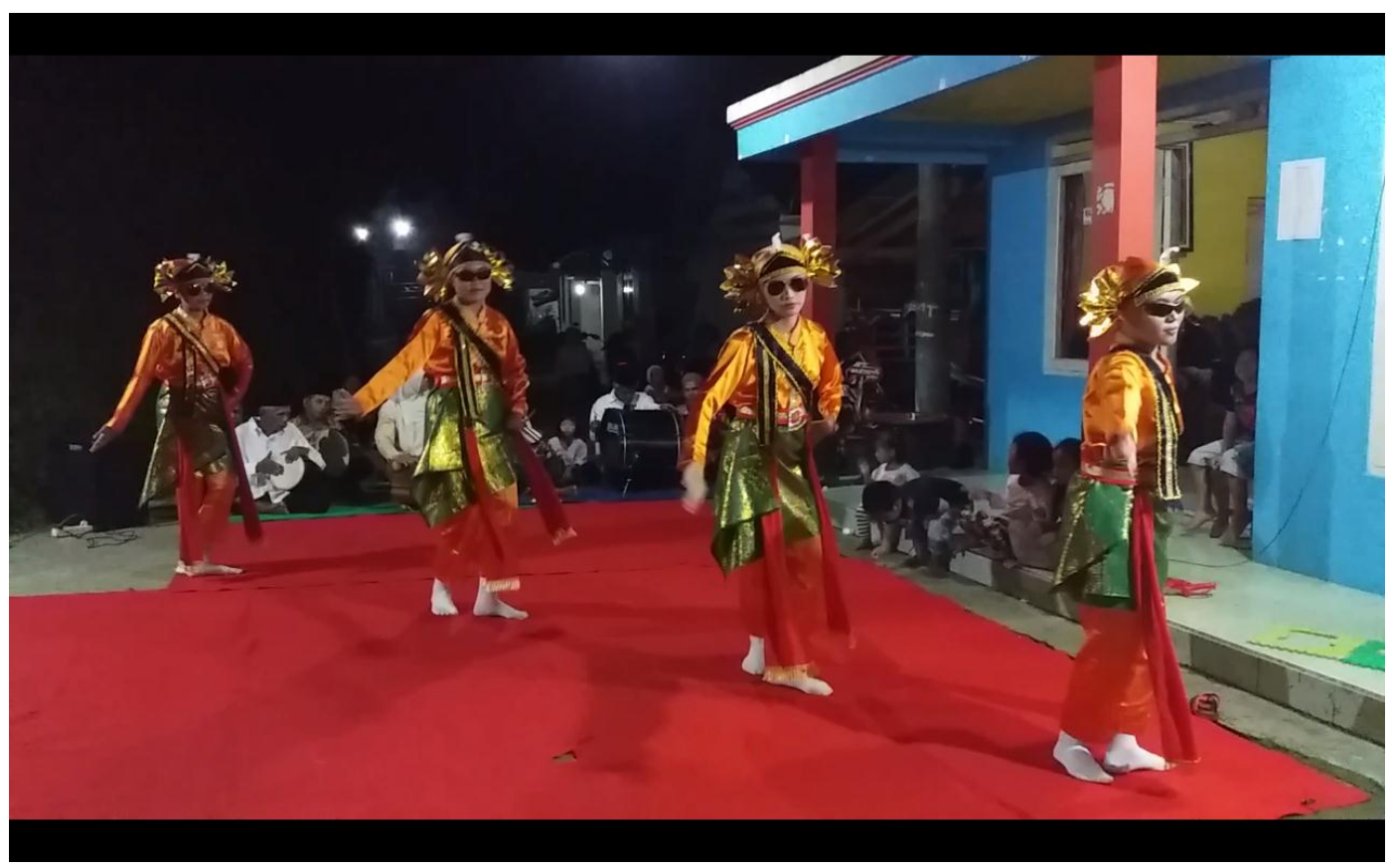

Foto 4.39. Arah Gerak Tari Opak Abang Serong ke Kiri Depan (Sumber: Dokumentasi Mawasti, 22 April 2017)

Pada foto 4.39. memperlihatkan arah gerak Tari Opak Abang serong ke kiri. Arah serong kiri depan ditimbulkan dari penari yang arah hadapnya serong ke kiri depan. Pada bagian ini, penari tidak terus-menerus menghadap serong ke kiri depan, melainkan juga berputar di tempatnya masing-masing sehingga arah hadapnya menjadi ke segala arah.

\subsection{Level Gerak Tari Opak Abang}

Level digunakan pada sebuah tarian untuk memberi suatu permainan tinggirendah dalam pertunjukan tari agar lebih bervariasi. Level yang terdapat pada gerak Tari Opak Abang bervariasi, ada level rendah, dan level sedang, akan tetapi 
level yang dominan dalam gerak Tari Opak Abang adalah level sedang. Level rendah digunakan sesekali pada beberapa gerakan.

Berikut adalah foto 4.40. yang menunjukan gerak Tari Opak Abang dengan level rendah.

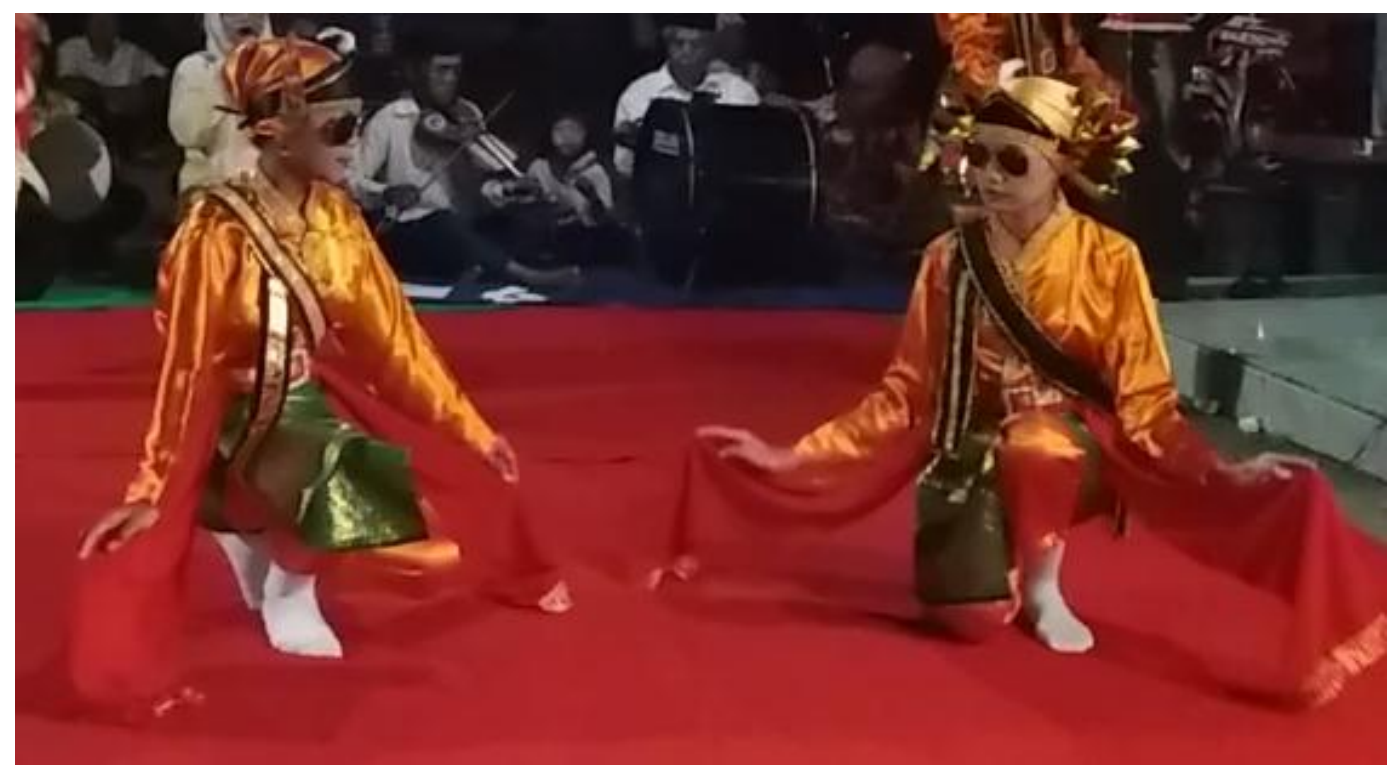

Foto 4.40. Gerak Tari Opak Abang Level Rendah

(Sumber: Dokumentasi Mawasti, 22 April 2017)

Foto 4.40. menunjukan level rendah dalam gerak Tari Opak Abang pada bagian Terang Bulan. Level rendah gerak terlihat pada salah satu lutut para penari yang menyentuh lantai panggung karena gerak dilakukan penari dengan posisi duduk pada salah satu kakinya. Level rendah dilakukan pada ragam gerak Terang Bulan untuk memberikan variasi-variasi tingkatan gerak sehingga terlihat lebih menarik. Gerakan pada foto 4.40 tidak hanya dapat dilakukan dengan level rendah, tetapi juga dapat dilakukan dengan level sedang. 
Berikut adalah level gerak yang dominan dalam Tari Opak Abang yang terlihat pada foto 4.41 .

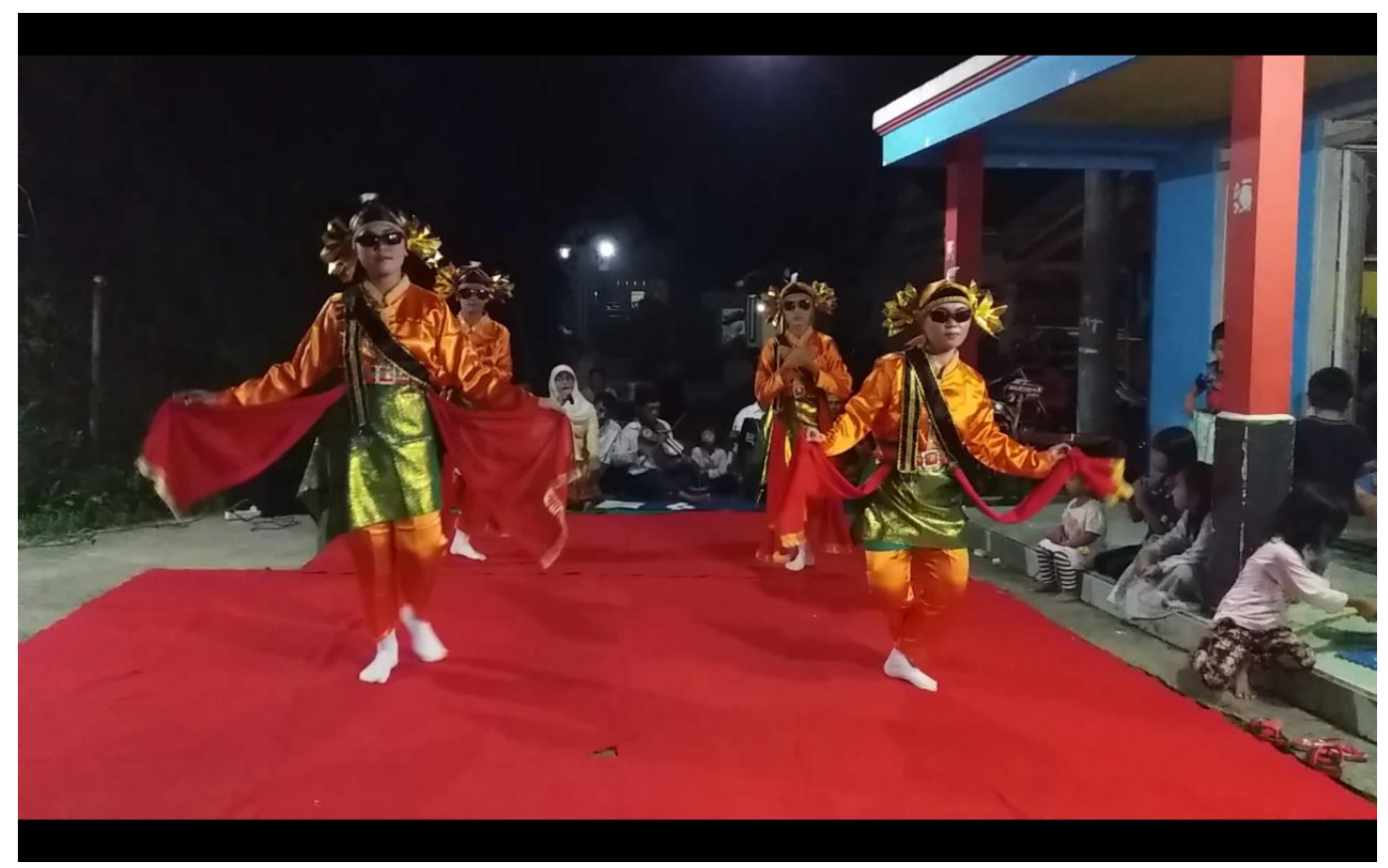

Foto 4.41. Gerak Tari Opak Abang Dominan Level Sedang (Sumber: Dokumentasi Mawasti, 22 April 2017)

Berdasarkan gerak pada foto 4.41. level gerak yang digunakan yakni level sedang. Level sedang digunakan pada sebagian besar gerak Tari Opak Abang. Pada gerak Tari Opak Abang tidak ada yang menggunakan level tinggi. level gerak yang terdapat dalam gerak Tari Opak Abang hanya level rendah dan level sedang. Level rendah yang ada dalam gerak Tari Opak Abang merupakan hasil variasi dari level gerak awalnya yaitu sedang. Tingkatan level rendah dan level sedang dapat menambah variasi dalam pertunjukan Tari Opak Abang. 


\subsection{Fokus Pandang Gerak Tari Opak Abang}

Fokus pandang dalam gerak Tari Opak Abang disesuaikan dengan arah hadap penari ketika sedang bergerak. Apabila arah hadap penari ketika bergerak ke arah serong kanan depan, makan secara langsung fokus pandang penari menjadi serong kanan depan, selain itu apabila penari bergerak menuju arah belakang atau membelakangi penonton, maka fokus pandang penari mengikuti arah hadapnya yaitu ke belakang.

\subsubsection{Waktu Gerak Tari Opak Abang}

Waktu merupakan salah satu elemen dalam gerak tari yang penting. Waktu di dalam gerak tari terdapat sub-sub elemen, yaitu: tempo, meter, dan ritme. Tempo dalam gerak Tari Opak Abang adalah sedang yang artinya secara umum gerak Tari Opak Abang tidak terlalu cepat dengan hitungan gerak 1 sampai 8. Meter dalam gerak Tari Opak Abang tetap, karena ketukan atau hitungan antara gerak satu dengan gerak yang lainnya tidak mengalami perubahan. Tari Opak Abang memiliki ritme gerak yang teratur, karena dalam setiap peralihan gerak terdapat suatu kesinambungan antar gerak satu dengan gerak yang selanjutnya.

\subsubsection{Tenaga Gerak Tari Opak Abang}

Tenaga yang ada pada gerak Tari Opak Abang bervariasi. Aksen atau tekanan yang terdapat dalam Tari Opak Abang berkekuatan sedang, hal ini disebabkan oleh tenaga dalam gerak Tari Opak Abang yang sebagian besar intensitasnya sedang, namun ada beberapa gerakan dengan intensitas tenaga lemah atau rendah sehingga mempunyai aksen/tekanan yang lebih rendah dan kualitas gerak yang 
lebih ringan dari gerakan lainnya, seperti pada ragam gerak Bunga Rampai yang ditunjukan dalam foto 4.42 .

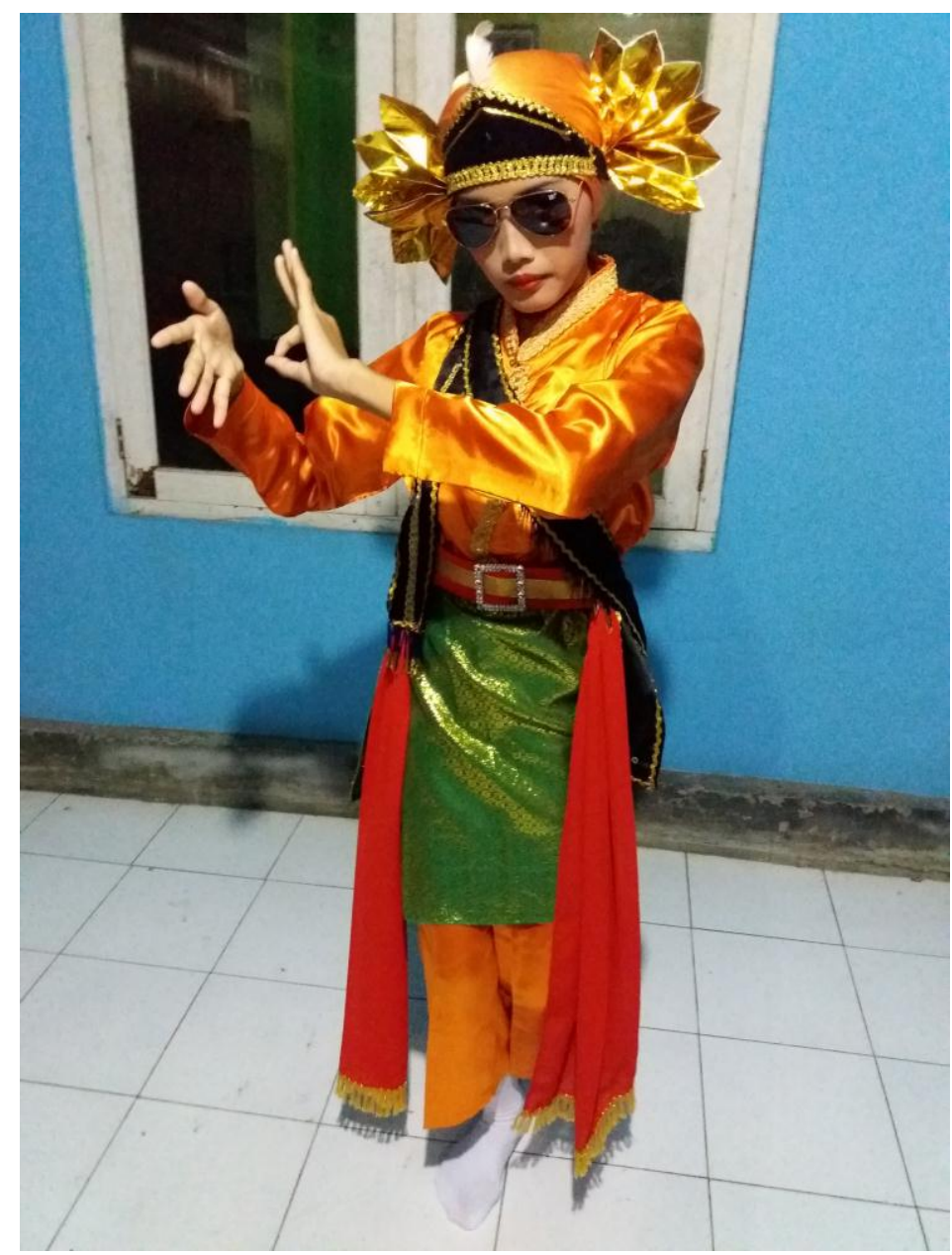

Foto 4.42. Gerak Tari Opak Abang yang Menggunakan Intensitas Tenaga Lemah (Sumber: Dokumentasi Mawasti, 8 Maret 2017)

Gerak Tari Opak Abang pada foto 4.42. menunjukan gerak dengan intensitas tenaga yang lemah. Gerak pada foto 4.42 memiliki intensitas tenaga yang lemah karena tenaga yang dikeluarkan penari sedikit ketika melakukan gerak seperti dalam gambar. Intensitas gerak pada foto 4.42. lemah sehingga menimbulkan kualitas gerak yang ringan. 


\subsubsection{Tata Rias dan Busana Tari Opak Abang}

\subsubsection{Tata Rias Tari Opak Abang}

Riasan pada Tari Opak Abang termasuk kategori rias korektif. Rias korektif merupakan rias yang berfungsi untuk menutupi kekurangan wajah dan menonjolkan kelebihan pada wajah. Rias dalam Tari Opak Abang sederhana, karena para penari Opak Abang merias diri secara otodidak dengan berbekal alat rias sederhana milik sendiri. Para penari Opak Abang di Desa Pasigitan tidak mempelajari rias secara khusus, melainkan belajar mandiri di setiap penampilannya. Berikut riasan penari Tari Opak Abang dalam foto 4.43.

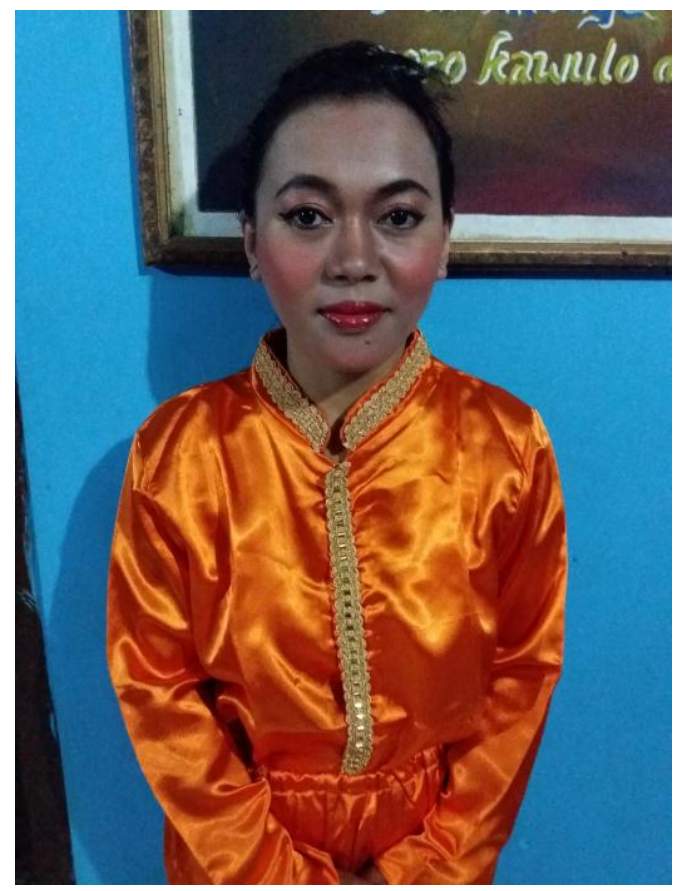

Foto 4.43. Tata Rias Wajah Tari Opak Abang (Sumber: Dokumentasi Mawasti, 22 April 2017)

Foto 4.43. merupakan contoh riasan dalam Tari Opak Abang yang menggunakan rias korektif untuk wajah para penari Opak Abang. Rias korektif 
menghasilkan riasan yang dapat menonjolkan kelebihan wajah penari dan kekurangan-kekurangan pada wajah penari dapat tertutupi. Rias korektif sengaja digunakan karena Tari Opak Abang merupakan tari rakyat yang sederhana, sehingga rias korektif dipilih oleh para penari karena penerapannya mudah dan praktis.

\subsubsection{Proses Rias Tari Opak Abang}

\subsection{Alat Rias Tari Opak Abang}

Berikut alat-alat yang digunakan dalam proses rias Tari Opak Abang, yaitu:

1. Bedak dasar/Foundation Powder : bedak yang digunakan sebagai alas make up

2. Bedak tabur : bedak yang teksturnya seperti serbuk

3. Bedak padat : bedak yang teksturnya serbuk yang dipadatkan

4. Pensil alis berwarna cokelat : pensil berujung lunak yang berwarna cokelat dan digunakan untuk menggambar pola alis

5. Eyeshadow palette : pewarna kelopak mata yang bertekstur serbuk yang dipadatkan dengan pilihan warna bermacam-macam, biasanya tersedia dalam bentuk palette maupun satuan

6. Lipstick berwarna merah : pewarna bibir yang terbuat dari olahan bahan-bahan alami yang kemudian dipadatkan dengan tambahan bahan kimia tertentu yang aman untuk manusia

7. Blush On : perona pipi dengan tekstur serbuk yang dipadatkan, biasanya berwarna merah muda. 
8. Eyeliner hitam : pemberi garis mata pada kelopak atas dan kelopak mata bagian bawah untuk mempertegas bentuk mata, bentuknya ada yang cair dan ada juga yang padat (seperti pensil alis)

9. Spons bedak dasar : berbentuk lingkaran, belah ketupat, maupun persegi dengan bahan spons yang lembut dan kenyal serta tebal

10. Spons bedak tabur : berbentuk lingkaran maupun persegi dengan bahan spons yang lembut tetapi agak tipis

11. Spons bedat padat : berbentuk lingkaran maupun persegi dengan bahan spons yang lembut dan kenyal tetapi agak tipis

12. Kuas eyeshadow : berbentuk seperti cotton bud, akan tetapi pada kedua ujungnya terdapat semacam bulatan 2 buah yang dilapisi dengan bahan spons

13. Kuas lipstick : berbentuk seperti kuas eyeshadow tetapi terdapat semacam bulu/rambut halus kecil-kecil pada salah satu ujungnya saja

14. Kuas blush on : bertangkai besar dan dilengkapi dengan bulu/rambut halus yang banyak dengan panjang medium. Dapat digunakan juga untuk memberikan Finishing Powder

15. Karet : untuk mengikat rambut ketika akan dicepol

16. Hairnet : rajut untuk mencegah rambut berantakan

17. Sisir : untuk merapikan rambut dari kekusutan

18. Cermin : untuk berkaca ketika sedang bersolek

19. Jepit biting, harnal : untuk mengaitkan aksesoris kepala dengan rambut serta merapikan rambut dibagian yang mudah rusak dan berantakan 


\subsection{Langkah-langkah Rias Tari Opak Abang}

\subsection{Tata Rias Wajah Tari Opak Abang}

Berikut langkah-langkah dalam merias wajah pada penari Tari Opak Abang, yaitu:

1. Bersihkan terlebih dahulu wajah dengan sabun pencuci muka/cairan pembersih muka dan keringkan

2. Pertama-tama, oleskan bedak dasar/foundation secara merata ke wajah

3. Setelah rata, berikan bedak tabur dengan cara ditepuk-tepuk ke wajah kemudian dilanjut dengan bedak padat sambil ditepuk-tepuk pula

4. Lalu, buat pola alis khusus rias cantik pada kedua alis menggunakan pensil alis berwarna cokelat agar warna tidak terlalu kontras

5. Ke empat, warnai kedua kelopak mata dengan menggunakan eyeshadow, pilih warna yang senada dengan kostum, beri warna putih untuk area tepat dibawah alis untuk memberi kesan highlight, pulas secara halus dan merata. Agar selaras dengan rona pipi, pada bagian lekukan mata dekat batang hidung diberi warna merah muda / peach

6. Selanjutnya, oleskan eyeliner di tepian masing-masing kelopak mata tepat di atas posisi bulu mata palsu, buat pola sudut mata yang tegas di ujung kedua mata. Oleskan eyeliner juga untuk kelopak mata bagian bawah

7. Beri perona pipi atau blush on di sepanjang tulang pipi hingga ke sudut telinga bagian atas, dagu dan serta sedikit untuk dahi

8. Beri shading pada tulang hidung dengan menggunakan eyeshadow berwarna putih agar hidung terlihat mancung 
9. Oleskan lipstick merah pada bibir secara merata.

\subsection{Tata Rambut Tari Opak Abang}

Berikut adalah langkah-langkah dalam menata rambut pada penari Tari Opak Abang, yaitu:

1. Untuk rambut, sisir terlebih dahulu agar tidak kusut

2. Disisir, ikat dan gelung rambut dengan menggunakan karet, posisikan cepol rambut tepat di ujung atas kepala bagian belakang

3. Agar rambut tidak berantakan, lapisi cepol rambut dengan hairnet, ikat ujung hairnet pada pangkal cepol rambut kemudian kaitkan dengan jepit biting.

\subsubsection{Tata Busana Tari Opak Abang}

Tari Opak Abang merupakan tarian yang memiliki ciri khas melayu dan corak agama Islam baik di dalam iringan maupun tata busananya. Tata busana Tari Opak Abang bersifat tertutup dengan dikenakannya baju lengan panjang, celana panjang, dan kain penutup kepala (kerudung) seperti yang dikatakan Ibu Pujiati berikut.

"Tari Opak Abang menggunakan baju berlengan panjang, sampur, kaos kaki berwarna putih, ikat kepala dengan bulu mentok di ujung bagian atas namanya plisir, kacamata hitam, kain songket, celana panjang, kain penutup kepala seperti kerudung, selempang, sabuk, dan kipas di telinga kanan serta kiri yang dibuat sendiri dari kertas berwarna emas"

Berdasarkan penuturan Ibu Pujiati pada wawancara tanggal 22 Januari 2017, Tari Opak Abang memiliki kostum dan atribut untuk pementasannya, yaitu baju berlengan panjang, sampur/selendang, kaos kaki berwarna putih, ikat kepala dengan bulu mentok di ujung atasnya atau biasa disebut dengan plisir, kacamata 
berwarna hitam, kain songket berwarna hijau, celana panjang, kain penutup kepala seperti kerudung, selempang, sabuk, dan kipas kertas berwarna emas di kanan dan kiri telinga. Tata busana dan atribut yang biasa dipakai saat pertunjukan Tari Opak Abang dapat dilihat pada foto 4.44.

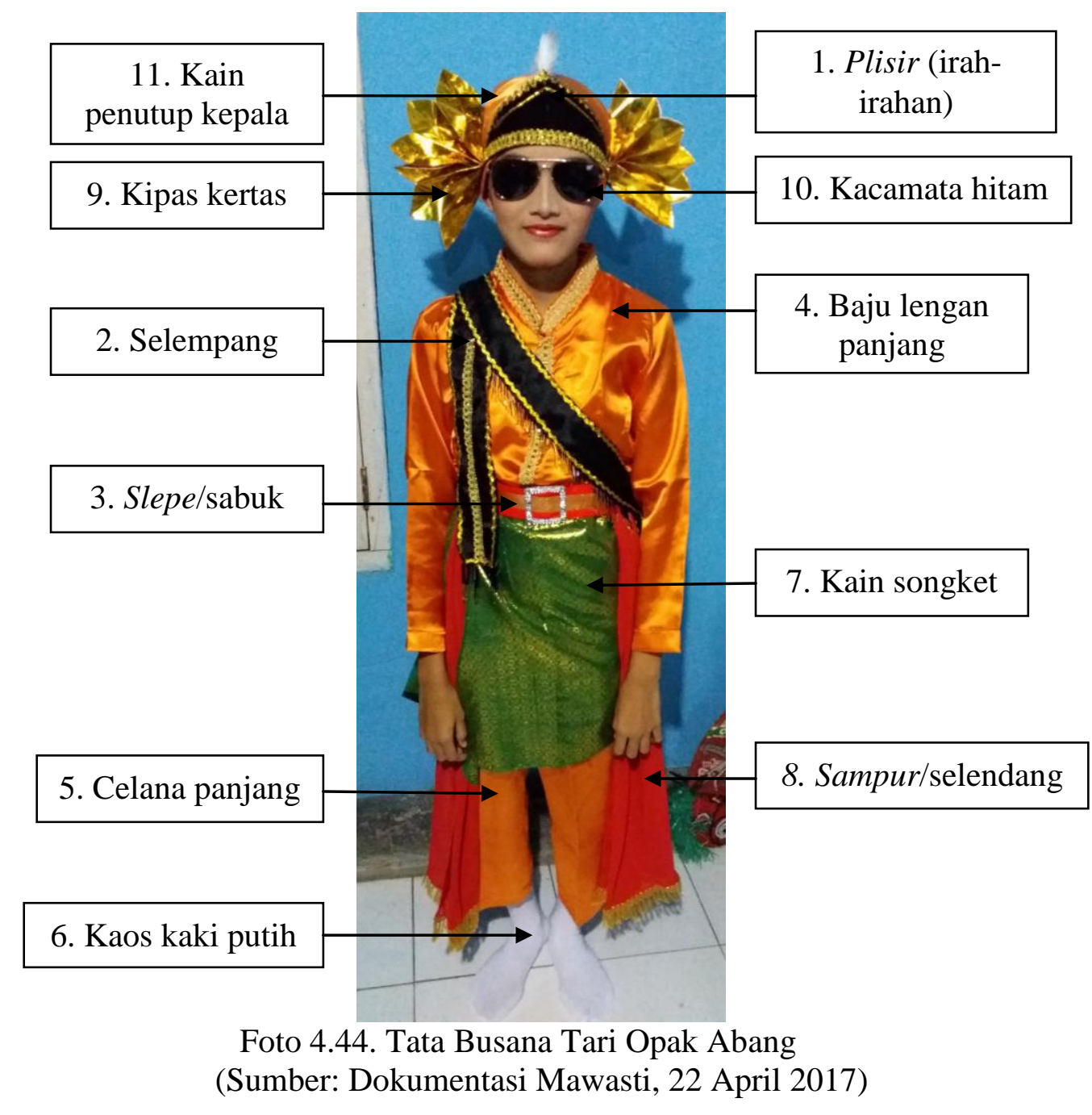

Berdasarkan foto 4.44. Tari Opak Abang pada setiap penampilannya menggunakan kostum dan atribut, yaitu: 1) Plisir (irah-irahan) dengan bulu mentok di ujung; 2) Selempang ; 3) Slepe (sabuk); 4) Baju lengan panjang; 5) 
Celana panjang; 6) Kaos kaki berwarna putih; 7) Kain songket; 8) Sampur/Selendang; 9) Kipas dari kertas emas untuk telinga; 10) Kacamata hitam; dan 11) Kain penutup kepala.

\subsection{Plisir/Irah-irahan Tari Opak Abang}

Hiasan untuk kepala penari Opak Abang biasa disebut dengan plisir/irahirahan. Plisir Tari Opak Abang diberi hiasan berupa bulu mentok pada ujung bagian atas seperti yang ada pada foto 4.45 .

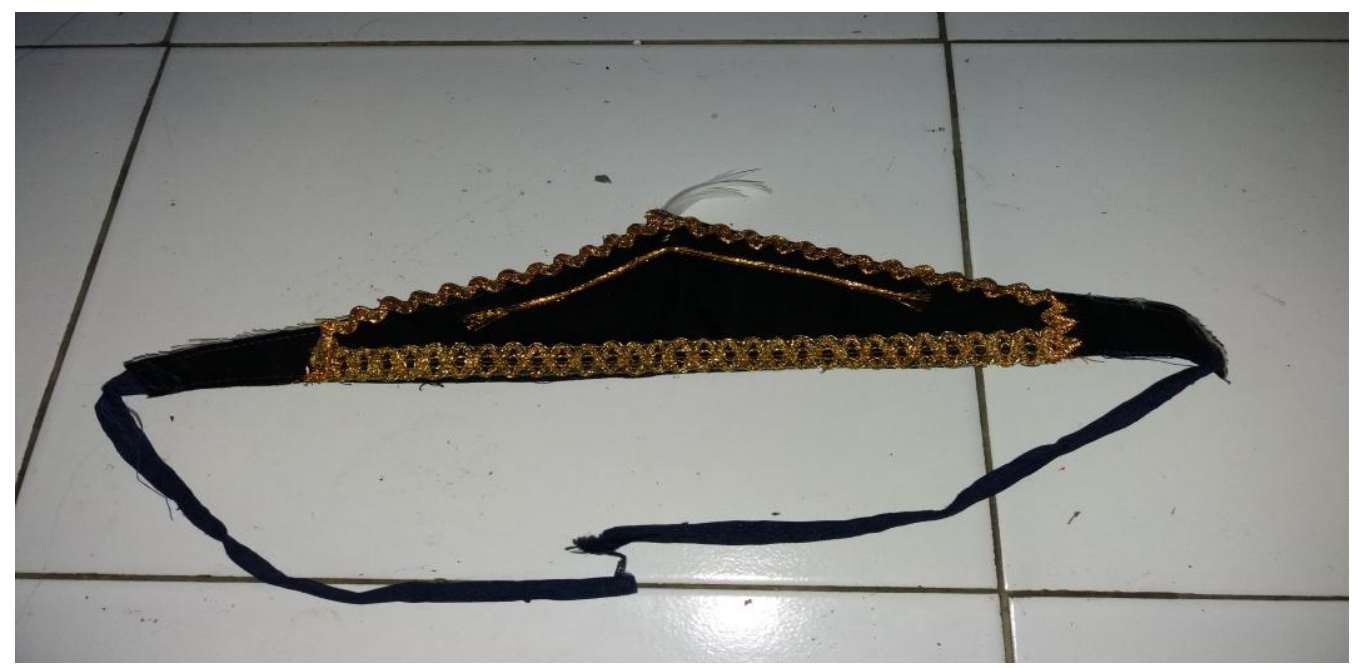

Foto 4.45. Plisir Tari Opak Abang

(Sumber: Dokumentasi Mawasti, 22 April 2017)

Foto 4.45. terlihat aksesoris atau hiasan yang dikenakan dengan cara diikatkan ke kepala penari Opak Abang. Aksesoris kepala Tari Opak Abang biasa disebut plisir oleh para penarinya di Desa Pasigitan. Plisir Tari Opak Abang terbuat dari kain beludru tipis yang berwarna hitam dan terdapat ornament berupa bordir berwarna emas pada tepi-tepinya. Plisir Tari Opak Abang berbentuk segitiga, yang pada dua ujungnya terdapat tali untuk mengikatnya di kepala. Pada 
ujung bagian atas plisir, terdapat bulu mentok yang sengaja disematkan untuk hiasan sebagaimana penuturan Ibu Pujiati (20 Januari 2017).

"Pada ujung plisir dipasang bulu mentok sebagai hiasan. Kenapa memakai bulu mentok, karena bulu mentok bisa melengkung indah."

Berdasarkan wawancara dengan Ibu Pujiati pada tanggal 20 Januari 2017, bulu mentok sengaja disematkan pada ujung plisir untuk hiasan karena bulu mentok bisa melengkung dengan indah. Bulu mentok didapatkan secara cumacuma dari penduduk Desa Pasigitan, karena banyak warga Desa Pasigitan yang beternak mentok.

\subsection{Selempang Tari Opak Abang}

Tari Opak Abang selalu menggunakan selempang pada kostum di setiap pementasan seperti yang ada di foto 4.46 .

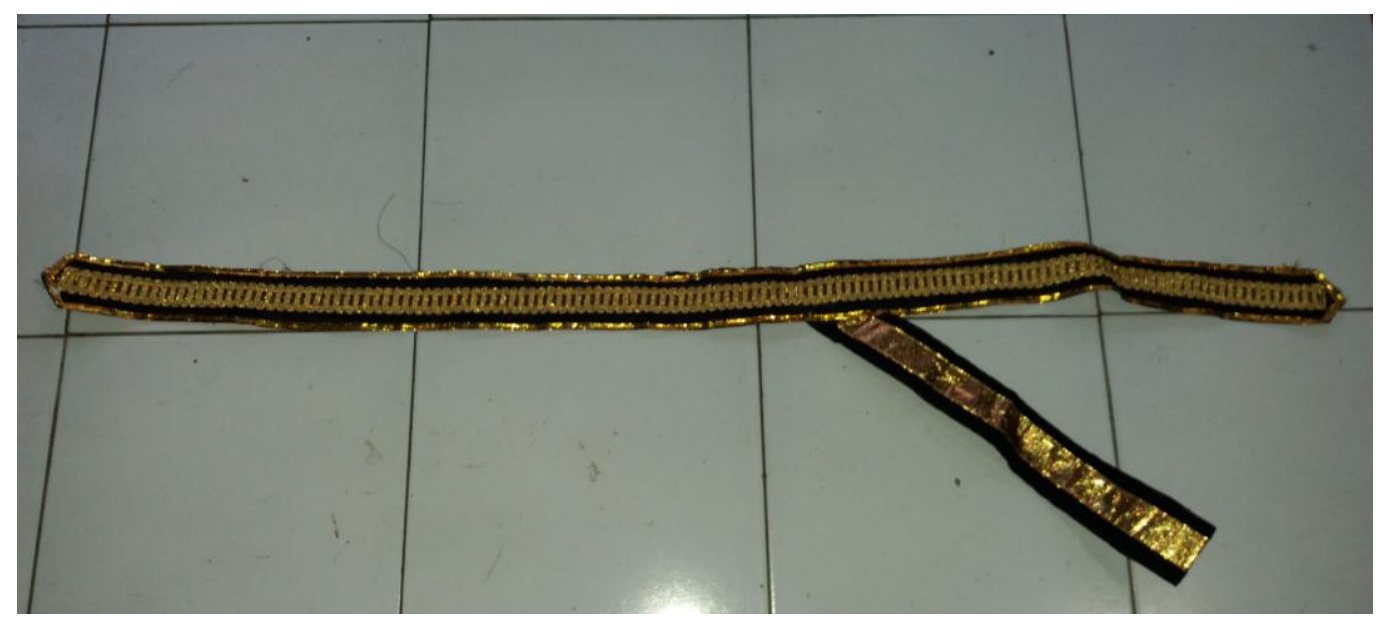

Foto 4.46. Selempang Tari Opak Abang

(Sumber: Dokumentasi Mawasti, 22 April 2017)

Pada foto 4.46. selempang merupakan kostum Tari Opak Abang yang terbuat dari kain berbahan katun berwarna hitam. Selempang dikenakan menyamping dari 
pundak kanan atas menuju pinggul kiri penari. Selempang dipasang setelah mengenakan baju lengan panjang dan slepe/sabuk. Selempang Tari Opak Abang memiliki ornament berupa border berwarna emas yang terdapat di tepi-tepi selempang, senada dengan plisir yang dikenakan di kepala. Selempang yang dikenakan memberi kesan kuat mengenai tema perjuangan Tari Opak Abang karena apabila diamati seperti selempang yang biasa dikenakan oleh prajurit pada masa kemerdekaan.

\subsection{Slepe/Sabuk Tari Opak Abang}

Slepe/sabuk pada Tari Opak Abang merupakan ikat pinggang yang dikenakan para penari seperti yang ada di foto 4.47 .

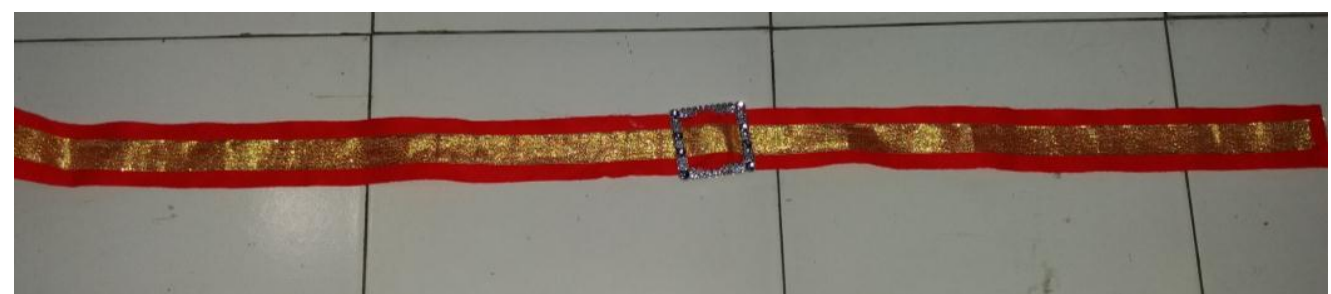

Foto 4.47. Slepe/sabuk Tari Opak Abang

(Sumber: Dokumentasi Mawasti, 22 April 2017)

Foto 4.47. memperlihatkan sabuk dalam Tari Opak Abang disebut dengan slepe. Slepe merupakan kostum yang dikenakan secara melingkar di pinggang penari. Slepe Tari Opak Abang berwarna merah, terbuat dari kain beludru yang diberi kain berwarna emas pada bagian tengahnya. Slepe berfungsi sebagai pemanis pinggul penari dan menutupi ikatan sampur. Ukuran slepe Tari Opak Abang kurang lebih panjangnya $50 \mathrm{~cm}$ dan lebarnya kurang lebih $10 \mathrm{~cm}$. 


\subsection{Baju Lengan Panjang Tari Opak Abang}

Pakaian Tari Opak Abang bersifat tertutup sehingga untuk kostum bagian atasan menggunakan baju lengan panjang seperti pada foto 4.48 .

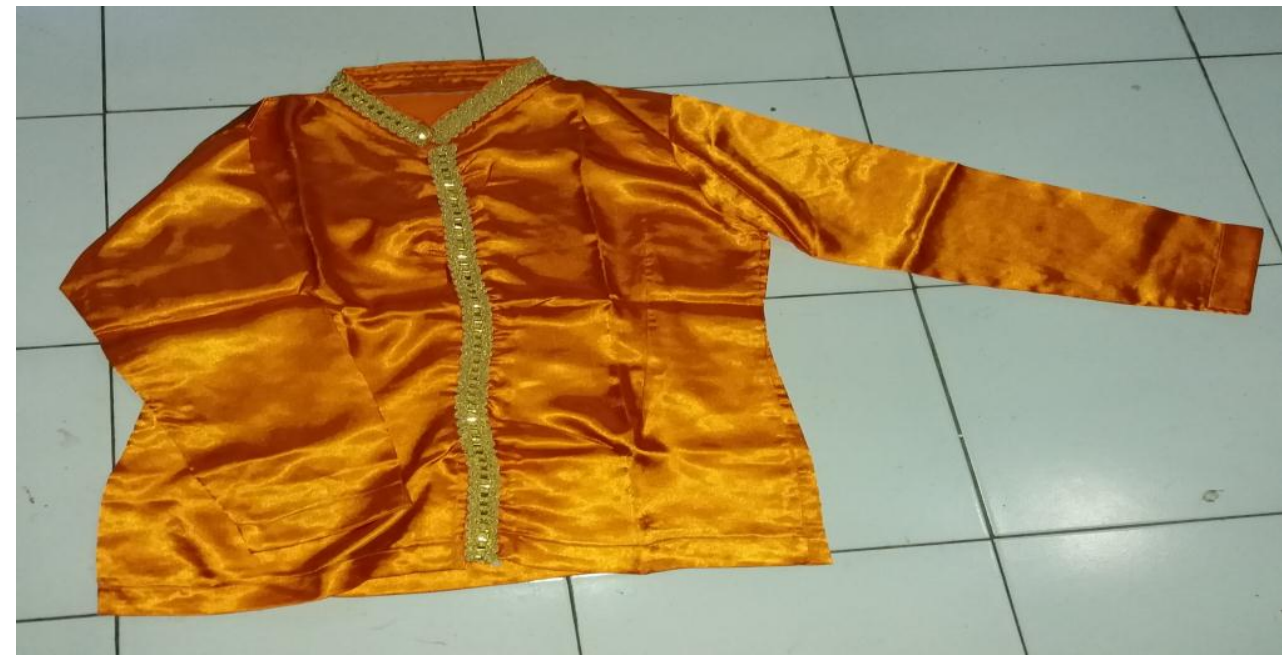

Foto 4.48. Baju Lengan Panjang Tari Opak Abang

(Sumber: Dokumentasi Mawasti, 22 April 2017)

Berdasarkan foto 4.48. Tari Opak Abang merupakan media syiar agama Islam, sehingga hal ini tercermin lewat baju lengan panjang yang dikenakan penari Opak Abang. Baju Tari Opak Abang memiliki lengan yang panjang sampai dengan pergelangan tangan penari. Bahan kain baju lengan panjang Opak Abang yaitu katun, karena kain katun dapat menyerap keringat sehingga nyaman dipakai untuk menari. Warna dalam pemilihan bahan katun Tari Opak Abang bebas, asalkan terlihat menarik ketika dikenakan saat pentas. Pada saat peneliti mengamati pertunjukan Tari Opak Abang, para penari menggunakan baju lengan panjang berwarna jingga. 


\subsection{Celana Panjang Tari Opak Abang}

Celana panjang merupakan pasangan busana dari baju lengan panjang Tari Opak Abang. Berikut celana panjang yang biasa dikenakan penari Opak Abang dapat dilihat pada foto 4.49 .

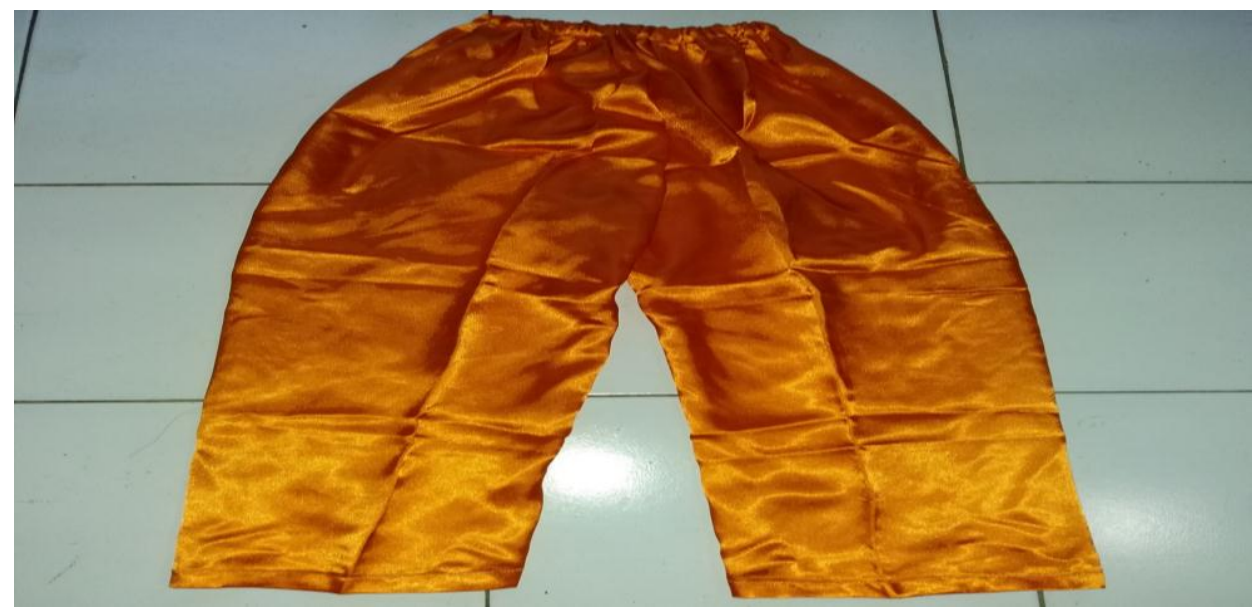

Foto 4.49. Celana Panjang Tari Opak Abang (Sumber: Dokumentasi Mawasti, 22 April 2017)

Berdasarkan foto 4.49. Tari Opak Abang mengenakan celana panjang sebagai kostum penutup bagian bawah. Panjang celana sampai dengan mata kaki, sehingga penari tidak akan terjerat ketika sedang bergerak. Bahan celana panjang menggunakan kain katun, sama seperti atasannya yaitu baju lengan panjang. Celana panjang yang digunakan pada Tari Opak Abang tidak menggunakan tali sebagai pengencangnya, melainkan menggunakan tali elastis yang dijahit di bagian pinggul celana agar lebih mudah dan praktis ketika dikenakan. Celana panjang sengaja dipilih untuk busana Tari Opak Abang karena akan membuat penari lebih tertutup, sebagaimana fungsi Tari Opak Abang sebagai syiar agama Islam sehingga penting kesesuaian tema dengan busana pada Tari Opak Abang. 


\subsection{Kaos Kaki Putih Tari Opak Abang}

Para penari Opak Abang menutupi kedua kaki dengan menggunakan kaos kaki berwarna putih seperti pada foto 4.50 .

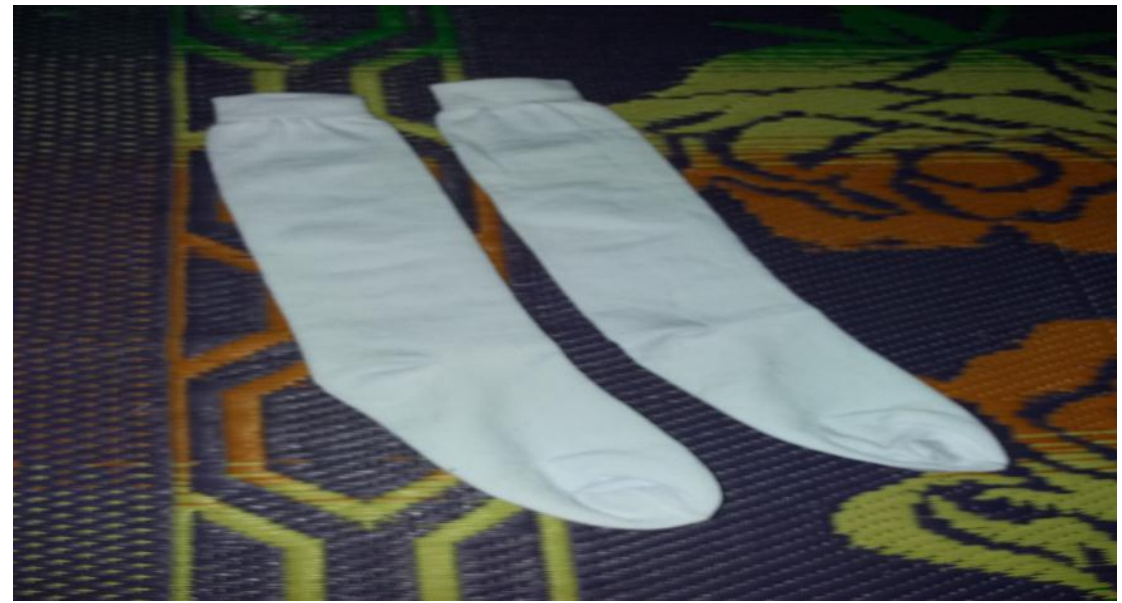

Foto 4.50. Kaos Kaki Putih Tari Opak Abang

(Sumber: Dokumentasi Mawasti, 22 April 2017)

Pada foto 4.50. menunjukan kaos kaki berwarna putih berfungsi sebagai penutup kaki penari. Kaos kaki berwarna putih sengaja dipakai untuk memberi kesan rapi dan bersih pada para penari Tari Opak Abang seperti yang disampaikan oleh Bapak Aris Salamun (20 Januari 2017).

"Dulu, Tari Opak Abang penarinya laki-laki yang kebanyakan berprofesi sebagai petani sehingga kakinya tidak mulus karena sering ke sawah tanpa alas kaki. Kalau pakai kaos kaki, penari akan terlihat lebih rapi dan bersih. Walaupun sekarang penarinya sudah perempuan, kaos kaki putih tetap dipakai dan menjadi ciri khas Tari Opak Abang”.

Berdasarkan hasil wawancara dengan Bapak Aris Salamun pada tanggal 20 Januari 2017, kaos kaki putih yang dikenakan saat tampil Tari Opak Abang awalnya hanya sebagai penutup alas kaki penari-penari terdahulu yang berjenis kelamin laki-laki dan bermata pencaharian sebagai petani. Oleh karena itu, kaos 
kaki putih dikenakan untuk memberi kesan rapi dan bersih. Kaos kaki putih akhirnya dipatenkan sebagai bagian dari tata busana Tari Opak Abang tidak hanya sebagai penutup kaki.

\subsection{Kain Songket Tari Opak Abang}

Para penari Opak Abang mengenakan kain songket yang dilingkarkan untuk menutupi pinggang Berikut kain songket yang biasa di pakai penari Opak Abang dapat dilihat pada foto 4.51 .

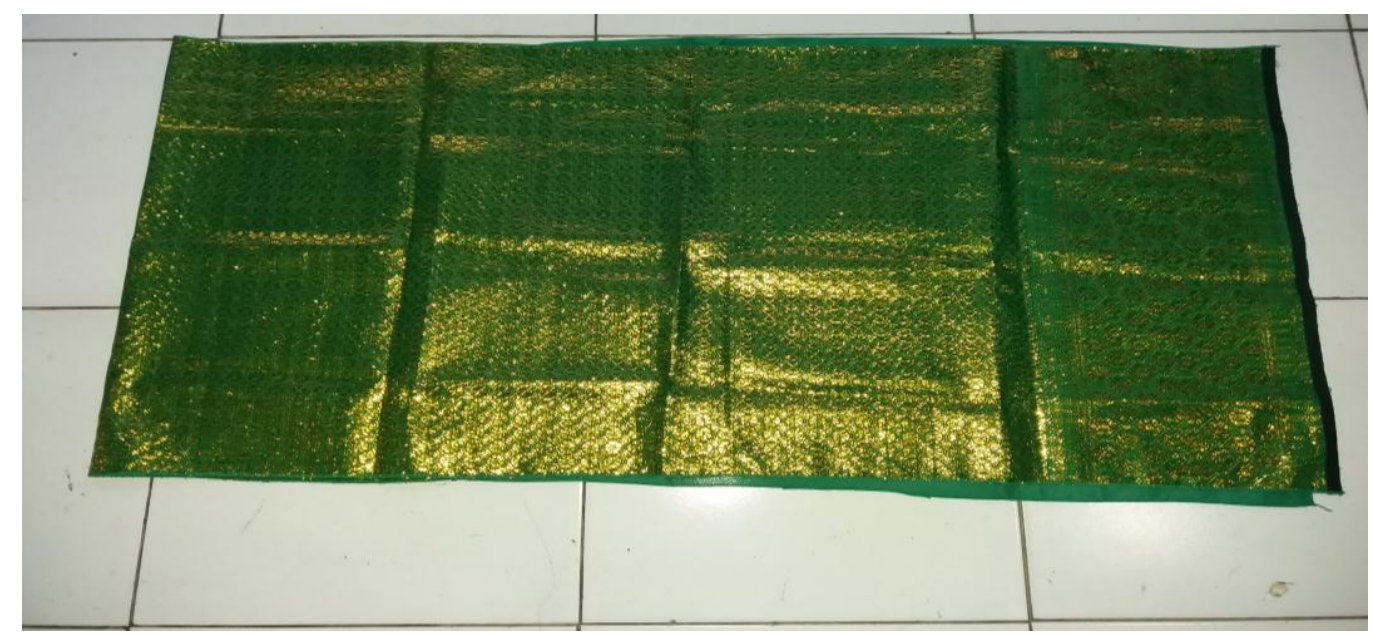

Foto 4.51. Kain Songket Tari Opak Abang

(Sumber: Dokumentasi Mawasti, 22 April 2017)

Berdasarkan foto 4.51. penggunaan kain songket pada Tari Opak Abang selain sebagai kelengkapan kostum, digunakan sebagai identitas Tari Opak Abang yang merupakan tari penyampai syiar agama Islam. Tari Opak Abang sebagai media syiar agama Islam, memiliki nuansa melayu pada busananya yang terlihat dari pemakaian kain songket pada kostum Tari Opak Abang. Kain songket dikenakan pada lingkar pinggang penari dengan cara ditekuk menjadi dua bagian berbentuk persegi panjang kemudian dilingkarkan pada pinggang. 


\subsection{Sampur/Selendang Tari Opak Abang}

Penari Opak Abang mengenakan sampur/selendang pada kedua pinggulnya. Sampur pada Tari Opak Abang tidak hanya digunakan sebagain pemanis kostum, tetapi juga digunakan pada saat menari sehingga untuk mempercantik diberi hiasan berupa kain renda pada kedua ujung sampur. Sampur/selendang Tari Opak Abang dapat dilihat pada foto 4.52.

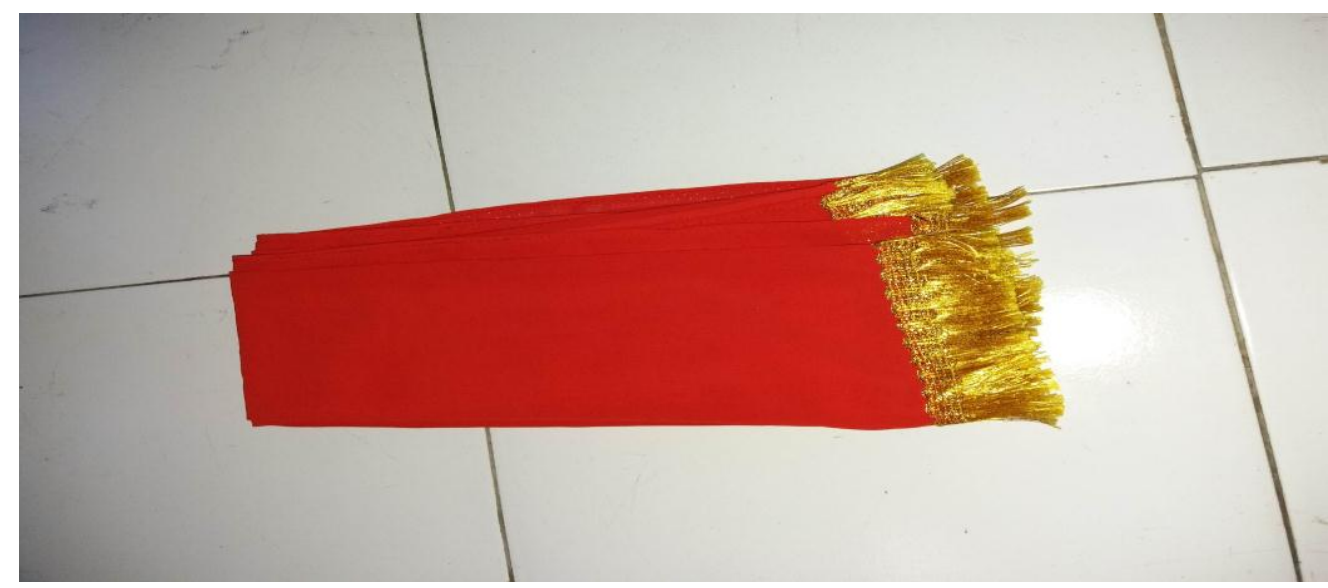

Foto 4.52. Sampur/selendang Tari Opak Abang (Sumber: Dokumentasi Mawasti, 22 April 2017)

Foto 4.52. menunjukan sampur atau selendang Tari Opak Abang dikenakan dengan cara diikat di tengah pinggang penari, setelah itu ditutupi dengan slepe. Sampur Tari Opak Obang berbahan ciffon dan sengaja dipilih warna yang cerah agar terlihat menarik, akan tetapi disesuaikan dengan warna kostum Tari Opak Abang keseluruhan.

\subsection{Kipas Kertas Tari Opak Abang}

Hiasan yang biasa dikenakan penari Opak Abang pada kedua telinganya adalah kertas emas yang dilipat dan dibentuk seperti kipas. Kipas emas berbahan 
kertas sengaja disematkan pada kedua telinga penari untuk hiasan telinga. berikut kipas kertas berwarna emas dapat dilihat pada foto 4.53 .

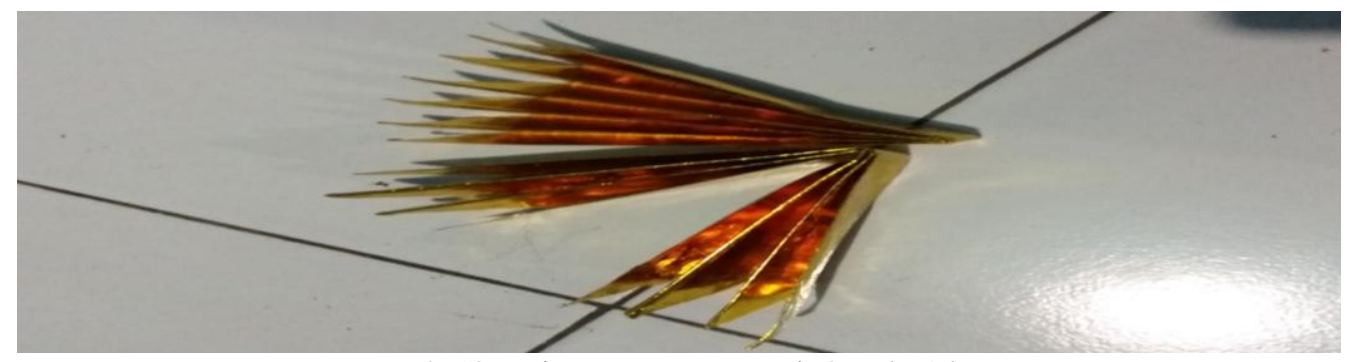

Foto 4.53. Kipas Kertas Tari Opak Abang

(Sumber: Dokumentasi Mawasti, 22 April 2017)

Foto 4.53. memperlihatkan hiasan Tari Opak Abang di atas telinga kanan dan kiri yang berbentuk seperti kipas kecil berwarna emas terbuat dari kertas yang dilipat sebanyak 7 kali. Kertas lipatan kemudian digunting lancip pada masingmasing ujungnya, kemudian diregangkan sampai membentuk setengah lingkaran seperti kipas.

\subsection{Kacamata Hitam Tari Opak Abang}

Kacamata hitam merupakan salah satu perlengkapan busana Tari Opak Abang yang selalu digunakan setiap pentas seperti pada foto 4.54 .

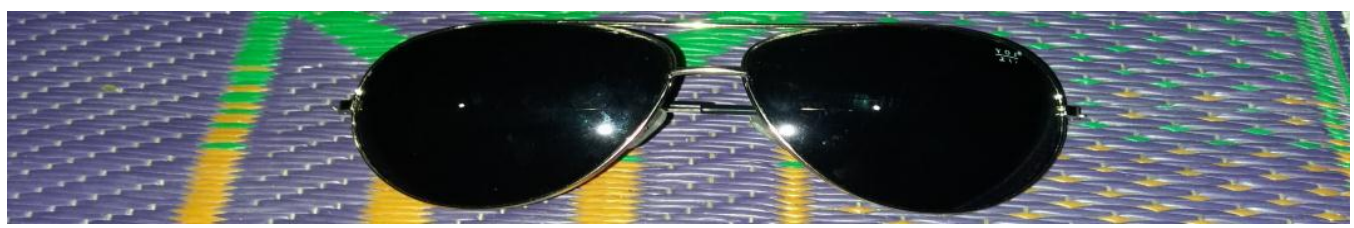

Foto 4.54. Kacamata Hitam Tari Opak Abang

(Sumber: Dokumentasi Mawasti, 22 April 2017)

Foto 4.54. memperlihatkan kacamata hitam pada Tari Opak Abang digunakan sebagai atribut pelengkap busana. Kacamata berwarna hitam sengaja dipilih 
karena awalnya berfungsi sebagai penyamar wajah penari Opak Abang, seperti penuturan Bapak Aris Salamun (20 Januari 2017).

"Kacamata hitam dulu digunakan untuk menutupi wajah penari, karena penarinya laki-laki tapi berdandan seperti perempuan sehingga bisa jadi para penari laki-laki malu kalau ketahuan wajah aslinya. Karena sudah turun temurun memakai kacamata, maka sekarang penari perempuan juga tetap memakai kacamata hitam".

Berdasarkan hasil wawancara dengan Bapak Aris Salamun pada tanggal 20 Januari 2017, kacamata hitam awalnya berfungsi sebagai penyamaran karena pada zaman dulu Tari Opak Abang ditarikan oleh penari laki-laki dan para penari lakilaki merasa malu apabila identitasnya diketahui oleh khalayak pada saat menarikan Opak Abang, akan tetapi sekarang kacamata hitam dijadikan atribut wajib pada tata busana Tari Opak Abang.

\subsection{Kain Penutup Kepala Tari Opak Abang}

Kain penutup kepala merupakan hasil pengembangan dari kebaya yang dikenakan di kepala pada penari Opak Abang terdahulu. Para penari Opak Abang menggunakan kain persegi untuk menutupi kepala, seperti pada foto 4.55 .

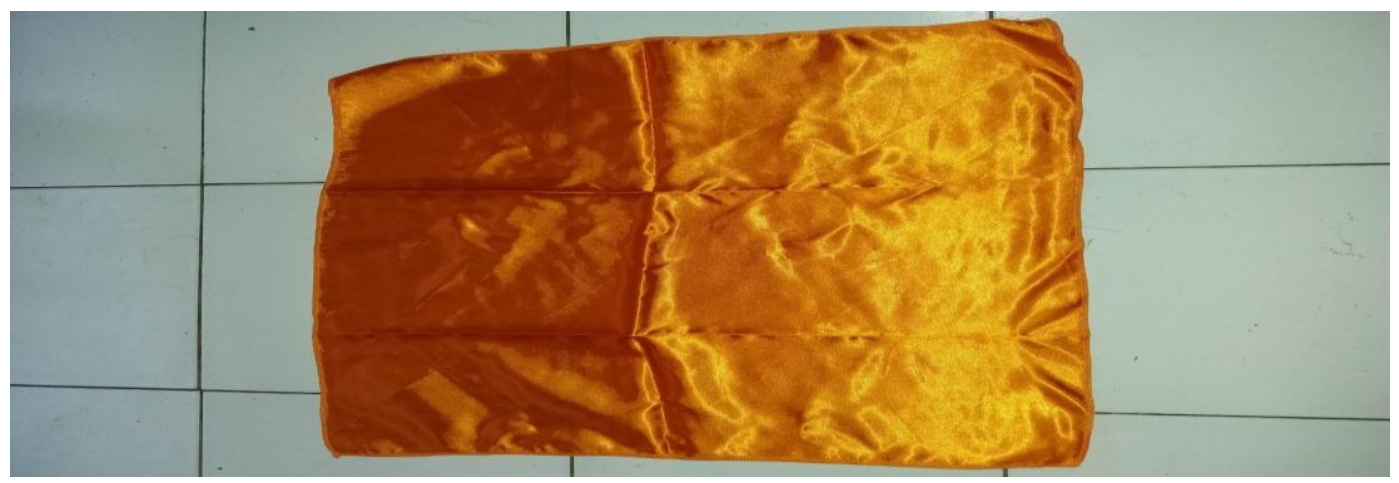

Foto 4.55. Kain Penutup Kepala Tari Opak Abang

(Sumber: Dokumentasi Mawasti, 22 April 2017) 
Foto 4.55. merupakan penutup kepala dari kain berbentuk persegi dengan ukuran kurang lebih $30 \mathrm{~cm}$ x $30 \mathrm{~cm}$. Pemakaian kain penutup kepala sama seperti memakai kerudung, akan tetapi bagian leher tetap terlihat karena kain dikaitkan dengan peniti pada bagian belakang leher penari. Kain penutup kepala menggunakan kain yang bahannya katun agar dapat menyerap keringat, untuk warnanya juga menyesuaikan dengan kostum keseluruhan yang dikenakan penari. Pemakaian kain penutup kepala menggambarkan Tari Opak Abang yang berfungsi sebagai syiar agama Islam di Desa Pasigitan.

\subsubsection{Proses Busana Tari Opak Abang}

Para penari Opak Abang memakai kostum usai rias wajah selesai. Proses memakai kostum Tari Opak Abang dapat dilihat dari foto 4.56.

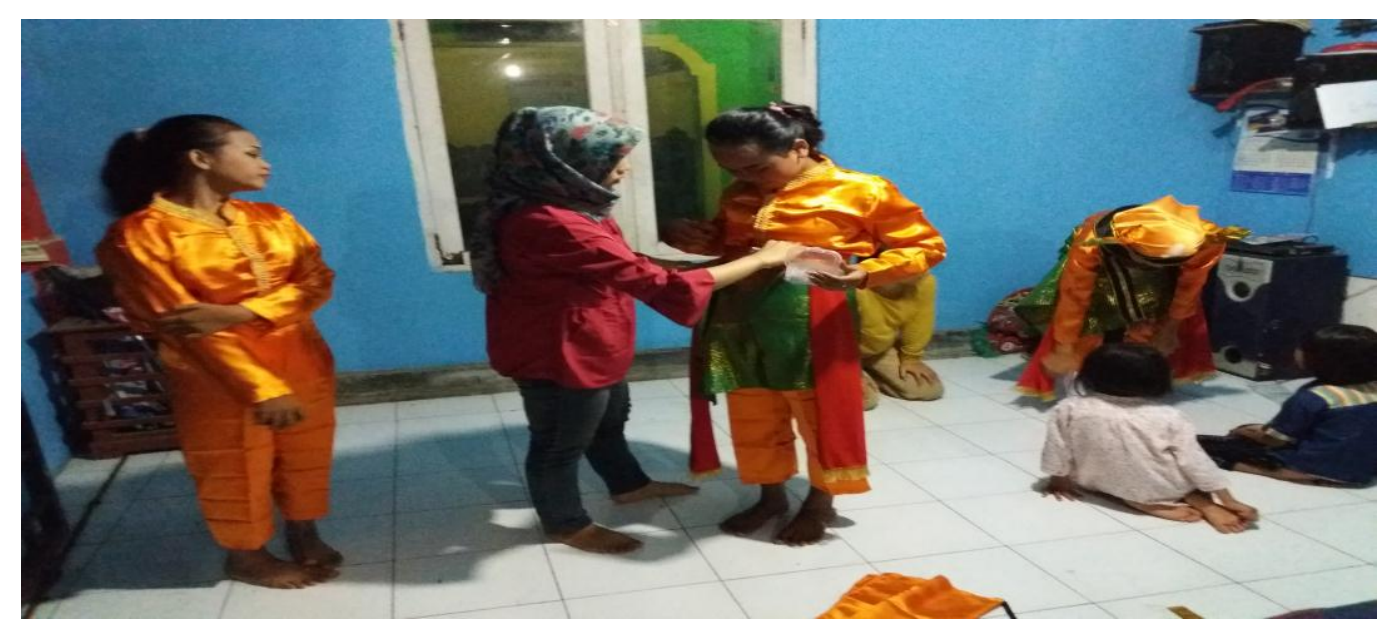

Foto 4.56. Proses Memakai Kostum Tari Opak Abang

(Sumber: Dokumentasi Mawasti, 22 April 2017)

Berdasarkan foto 4.56. terlihat para penari sedang mengenakan kostum Tari Opak Abang. Para penari mengenakan kostum Tari Opak Abang dengan dibantu 
oleh rekan-rekan Bapak Aris Salamun dan peneliti. Berikut merupakan langkahlangkah dalam memakai busana Tari Opak Abang:

1. Memakai kain penutup kepala, dengan mengaitkannya dengan peniti pada bagian belakang leher

2. Memasang plisir melingkari kepala dan mengikatnya di belakang kepala

3. Memasang hiasan kipas emas pada kedua telinga, kanan dan kiri

4. Kemudian, mengenakan baju lengan panjang dan mengenakan celana panjang

5. Memasang kain songket melingakari pinggul, dan membiarkan bagian kiri songket terlipat menjadi segitiga (diwiru capit urang)

6. Mengikat sampur yang telah disesuaikan panjang kanan kirinya pada tengah perut penari

7. Setelah itu, ikatan sampur ditutupi dengan sabuk yang dipasang melingkari pinggul penari dan dipeniti pada bagian belakang

8. Memakai selempang pada pundak kanan sampai dengan pinggul kiri

9. Memakai kaos kaki pada kaki kanan dan kiri

10. Terakhir, memakai kacamata hitam.

\subsubsection{Musik/Iringan Tari Opak Abang}

Tari Opak Abang diiringi oleh 6 orang pemusik dan 1 orang sindhen. Berikut alat-alat musik yang digunakan untuk mengiringi Tari Opak Abang, yaitu : 1) Rebana 2 buah; 2) bass drum 1 buah; 3) ketipung 1 buah; 4) biola 1 buah; dan 5) kecrek 1 buah. Pola permainan rebana dalam iringan Tari Opak Abang saling bersahut-sahutan antar satu rebana dengan rebana lainnya menggunakan 1 ketukan imbal-imbalan. 
Iringan Tari Opak Abang menggunakan tangga nada diatonis. Berikut tangga nada diatonis pada iringan Tari Opak Abang berdasarkan keterangan dari Gilang (28 Februari 2017).

"Iringan menggunakan tangga nada diatonis disebut juga sistem solmisasi terdiri dari nada do re mi fa sol la si do".

Berdasarkan hasil wawancara dengan Gilang Surya Saputra pada tanggal 28 Februari 2017, iringan Tari Opak Abang menggunakan tangga nada diatonis karena iringan Tari Opak Abang menggunakan alat musik dengan ciri khas melayu yaitu terbang sehingga tangga nada yang digunakan diatonis dengan sistem nada solmisasi yaitu do re mi fa so la si do.

\subsubsection{Rebana}

Rebana yang digunakan untuk mengiringi Tari Opak Abang dapat dilihat pada foto 4.57 .

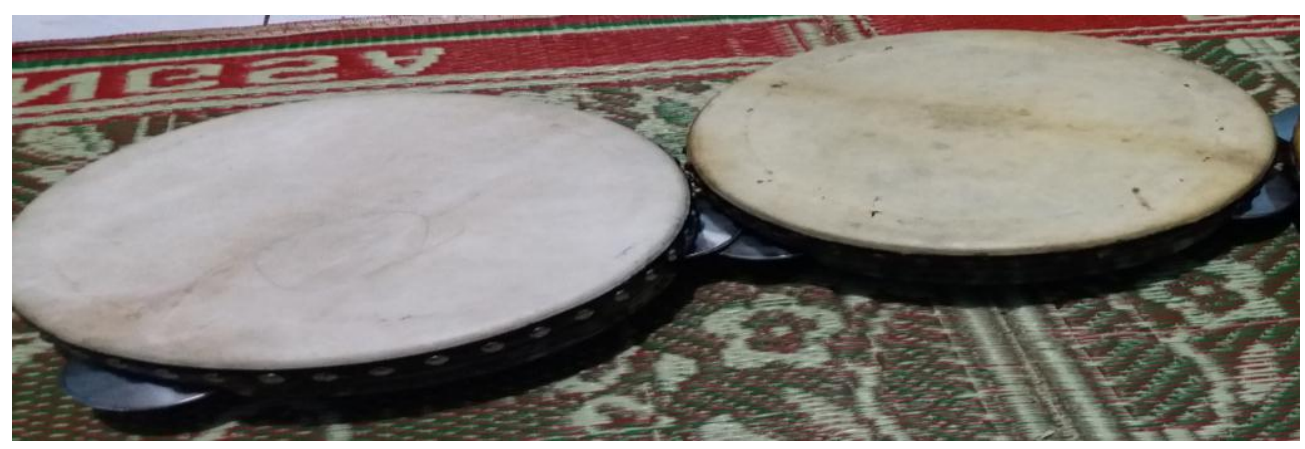

Foto 4.57. Alat Musik Rebana

(Sumber: Dokumentasi Mawasti, 30 Januari 2017)

Foto 4.57. menunjukan 2 rebana yang digunakan sebagai alat musik pengiring

Tari Opak Abang. Rebana yang digunakan pada setiap penampilan Tari Opak Abang biasanya berjumlah 2 buah. Rebana yang digunakan sengaja berjumlah 
lebih dari 1 agar iringan terdengar lebih meriah di telinga para penari dan juga para penonton. Rebana dimainkan dengan cara salah satu tangan memegang tepi rebana (bagian berbahan kayu), dan tangan yang satu memukul pada bagian tengah (bagian berlapis kulit) menggunakan tangan sampai berbunyi "prak" dan sesuai dengan irama.

\subsubsection{Bass Drum}

Alat musik bass drum yang dipakai dalam pertunjukan Tari Opak Abang dapat dilihat pada foto 4.58 .

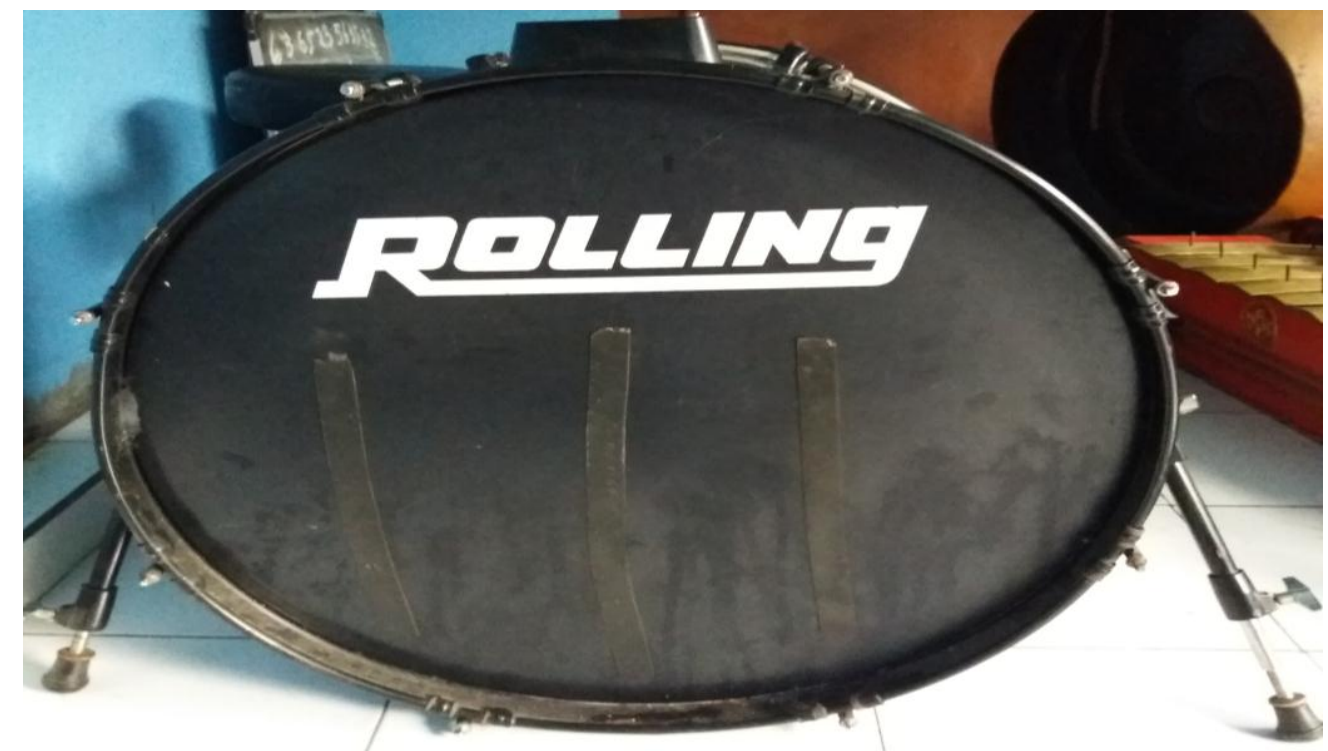

Foto 4.58. Alat Musik Bass Drum

(Sumber: Dokumentasi Mawasti, 30 Januari 2017)

Foto 4.58. menunjukan alat musik bass drum. Bass drum yang digunakan dalam iringan Tari Opak Abang berjumlah 1 buah. Bass drum digunakan pada iringan Tari Opak Abang untuk menimbulkan kesan megah dengan suara menggema yang dihasilkan oleh alat musik bass drum. Bass drum merupakan pengganti alat musik jidur yang sekarang sudah sulit untuk ditemukan di Desa 
Pasigitan. Bass drum dimainkan dengan cara dipukul pada bagian tengah menggunakan alat pemukul seperti pada foto 4.59 .

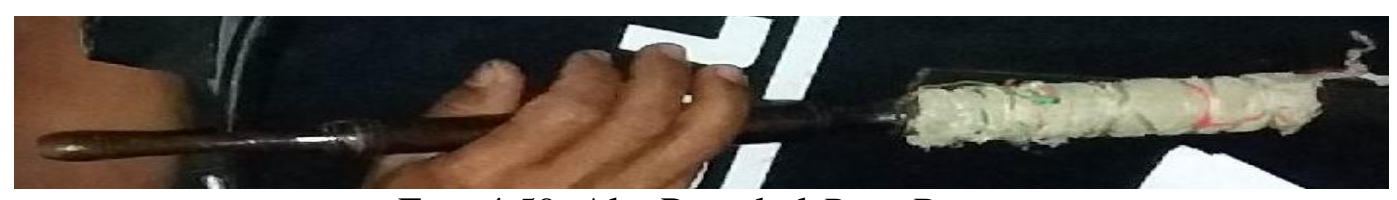

Foto 4.59. Alat Pemukul Bass Drum

(Sumber: Dokumentasi Mawasti, 22 April 2017)

Berdasarkan foto 4.59. cara memainkan bass drum yaitu dengan memukulkan alat pemukul ke bagian tengah bass drum. Bass drum dipukul hingga menimbulkan bunyi “dung” yang menggema dan sesuai dengan irama.

\subsubsection{Ketipung}

Ketipung yang biasa digunakan dalam iringan Tari Opak Abang dapat dilihat pada foto 4.60. berikut.

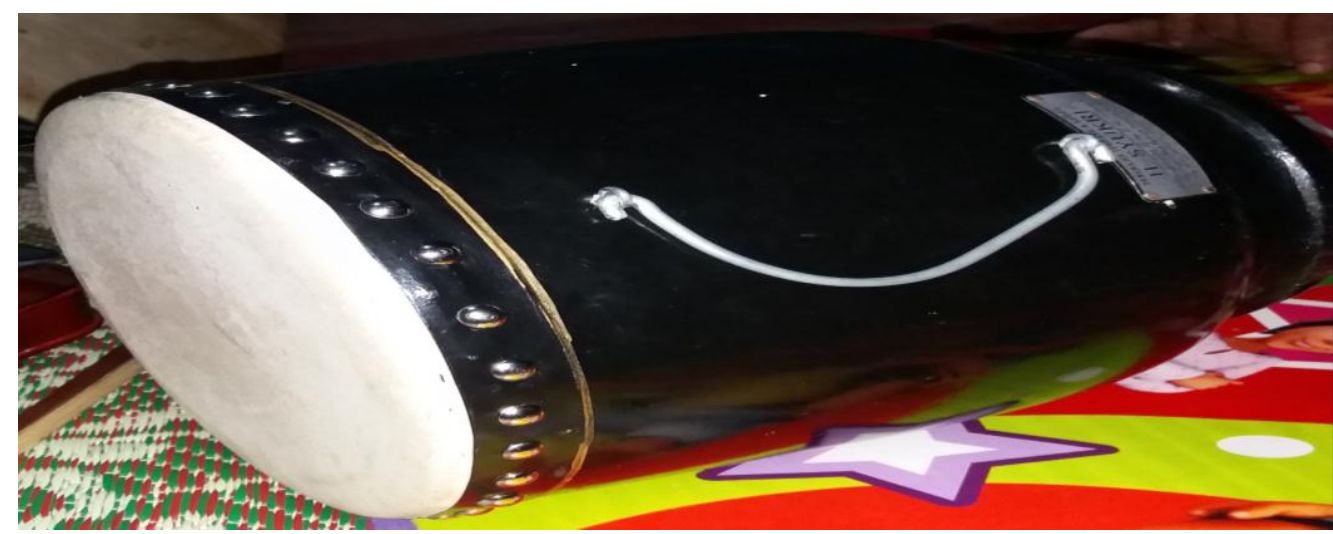

Foto 4.60. Alat Musik Ketipung

(Sumber: Dokumentasi Mawasti. 30 Januari 2017)

Foto 4.60. merupakan foto ketipung untuk musik pengiring Tari Opak Abang.

Ketipung yang digunakan dalam musik iringan Tari Opak Abang memiliki ciri- 
ciri yaitu hanya memiliki satu sisi. Sejak dulu, alat musik ketipung yang digunakan dalam iringan Tari Opak Abang yakni ketipung satu sisi, disebut ketipung satu sisi karena hanya ada lembaran selaput kulit pada salah satu sisinya sementara sisi lainnya terbuka. Ketipung satu sisi merupakan alah satu alat musik untuk iringan Tari Opak Abang yang terus dipertahankan penggunaannya hingga kini. Cara memainkan ketipung satu sisi yaitu dengan cara dipukul pada bagian tengah (bagian berlapis kulit) menggunakan telapak tangan dan jari-jari sampai menimbulkan bunyi "pung” dan sesuai dengan irama.

\subsubsection{Biola/Violin}

Alat musik yang digunakan untuk mengiringi Tari Opak Abang yaitu biola seperti pada foto 4.61 .

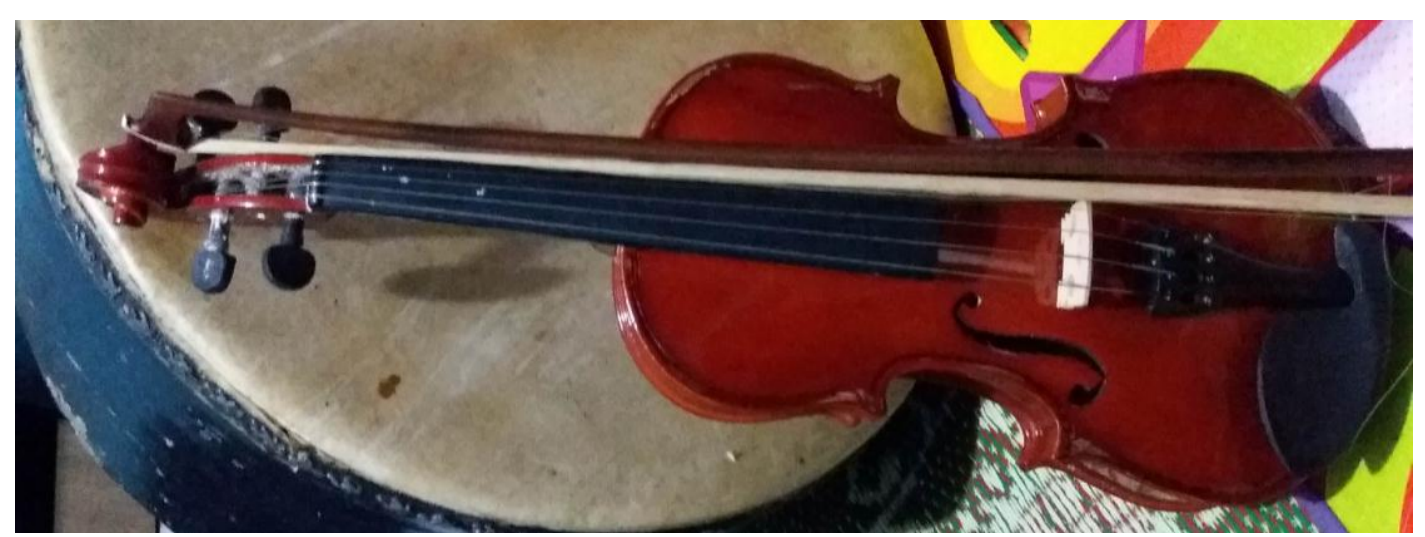

Foto 4.61. Alat Musik Biola dan Bow

(Sumber: Dokumentasi Mawasti. 30 Januari 2017)

Foto 4.61. menunjukan alat musik biola yang digunakan dalam musik iringan Tari Opak Abang. Biola pada iringan Tari Opak abang zaman dahulu menggunakan biola yang dibuat secara mandiri akan tetapi seiring perkembangan zaman, kini biola sudah banyak dipasarkan di toko-toko sehingga biola dalam 
iringan Tari Opak Abang tidak lagi menggunakan biola yang dibuat sendiri oleh pemusiknya. Biola dimainkan dengan menggunakan alat gesek yang disebut dengan bow. Cara menggesek biola yaitu salah satu tangan memegang biola dan menekan senar biola, lalu tangan yang satu memegang bow dan menggesekkan bow ke senar biola sampai berbunyi sesuai dengan melodi dan irama.

\subsubsection{Kecrek}

Alat musik kecrek yang digunakan untuk mengiringi Tari Opak Abang dapat dilihat pada foto 4.62 . berikut.

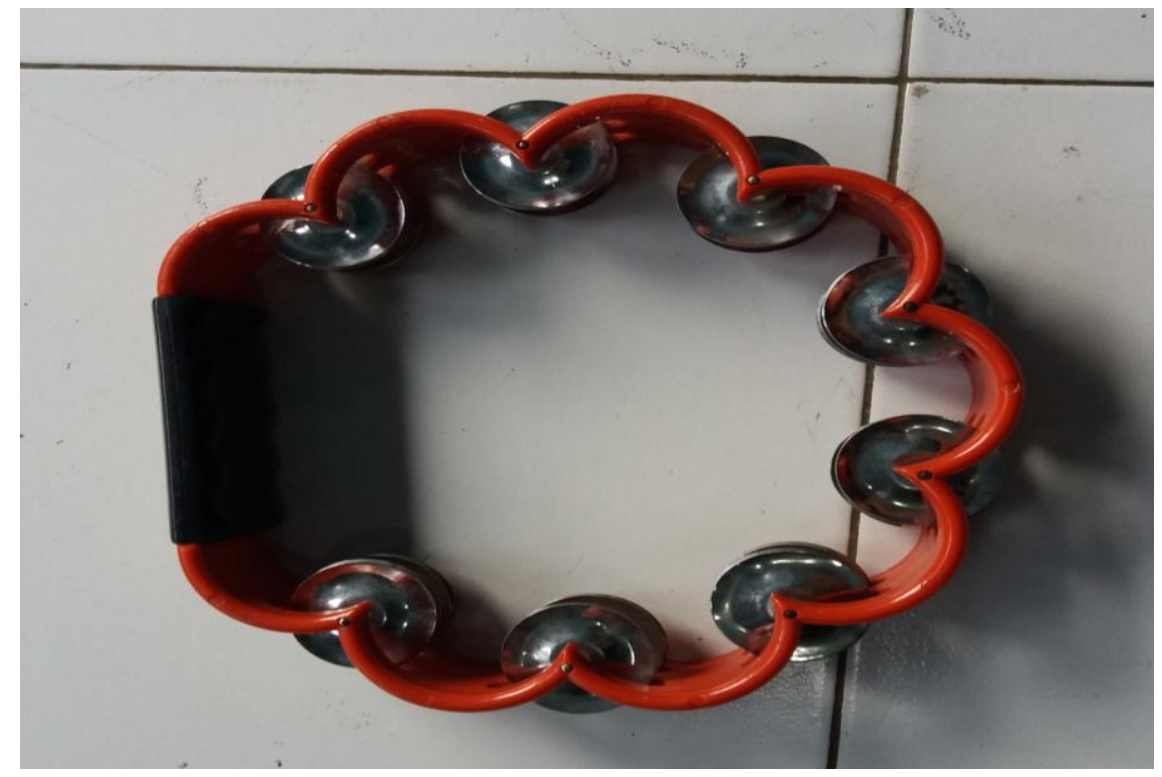

Foto 4.62. Alat Musik Kecrek

(Sumber: Dokumentasi Mawasti, 30 Januari 2017)

Foto 4.62. menunjukan alat musik kecrek yang digunakan dalam iringan Tari Opak Abang. Kecrek merupakan alat musik tambahan pada iringan Tari Opak Abang. Pemusik Tari Opak Abang sengaja menyertakan alat musik kecrek karena menurut para pemusik Tari Opak Abang, adanya kecrek dapat membuat iringan 
Tari Opak Abang lebih terdengar meriah. Kecrek dimainkan dengan cara salah satu tangan menggenggam bagian bawah kecrek dan memukulkan bagian kecrek yang berisi lempengan-lempengan logam ke telapak tangan yang lain sampai menimbulkan bunyi "crik" dan sesuai dengan irama.

\subsubsection{Notasi dan Syair Iringan Tari Opak Abang}

Berikut merupakan notasi dan syair yang biasa digunakan dalam iringan Tari Opak Abang.

1) Mars (perpindahan)

\begin{tabular}{|c|c|c|c|c|c|}
\hline & & & & & \\
\hline ..56715 & 6715653 & .35432 & 3421712 & 3421713 & ..2121 \\
\hline $.5 \overline{655}$ & $\overline{54} \overline{54} \overline{325}$ & 5454325 & $54 \overline{54} \overline{342}$ & $\overline{3421713}$ &. $.2 \overline{121}$ \\
\hline$\overline{. .5655}$ & $\overline{5454} \overline{321}$ & & & & \\
\hline
\end{tabular}

2) Gayung Seribu Gayung

$$
\begin{aligned}
& \text { - } 233 \overline{35} \overline{43} \overline{41} 2.5 \overline{.6} 3 \overline{35} \overline{43} \\
& \text { Ga-yung se-ri-bu ga-yung ga-yung se-ri-bu } \\
& \begin{array}{lllllllll}
\overline{41} & 2 & .2 & \overline{23} & \overline{16} & \overline{56} & 1
\end{array} \\
& \text { ga-yung Ga-yung da - ri Se-ma-rang } \\
& \begin{array}{rllllllll}
\hline 22 & 3 & \overline{3} 5 & \overline{43} & \overline{41} & 2 & .5 .6 & 3 & 35
\end{array} \\
& \text { Si-a-pa men-da-pat un-tung Si-a-pa men-da- }
\end{aligned}
$$

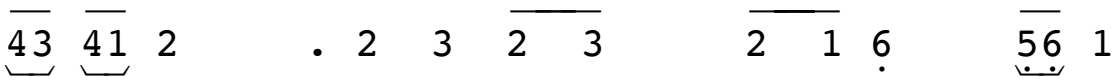

$$
\begin{aligned}
& \text { pat un-tung men-da-pat un-tung ka-sih-kan o-rang }
\end{aligned}
$$


3) Opak-Opak

$\begin{array}{lllllllllllllll}\text { - } 3 \quad \overline{31} & 2 & \overline{12} & 3 & 6 & 6 & \overline{.6} & 3 & \overline{31} & 2 & \overline{1} & 2 & 3 & 2 & 1\end{array}$

Pak-o-pak on-deon-de ge- lung pa-pak singa-yu dhe-we

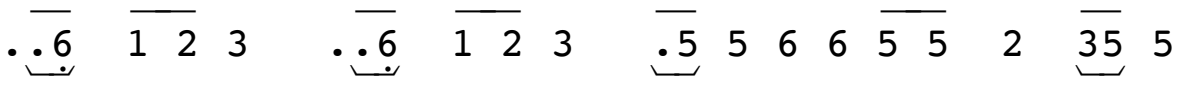

a-duh-sa-yang a-duh-sa-yang sa-tu ka-li ter-ba-yang ba-yang

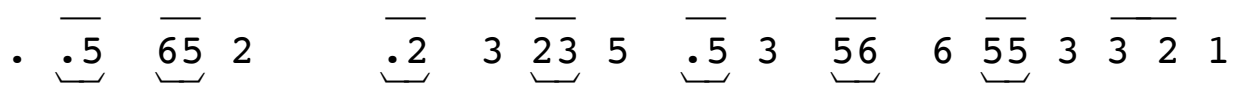

Pring o -ri nggo su-li-ngan ce-gat mbu-ri me-tu $i$ - ri-ngan

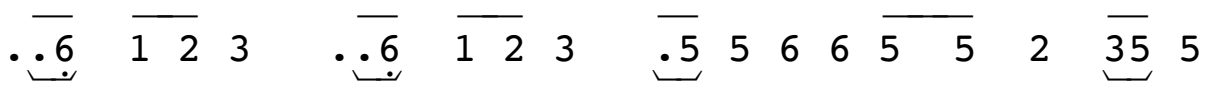

a- duhsa-yang a-duh sa-yang sa- tu ka-li ter-ba-yang-ba-yang

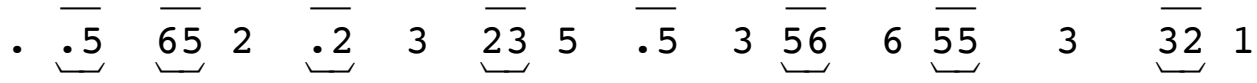

Pring-am-pel nggo ca- gakpo-go nde-pe- pel koyo Wong lo- la

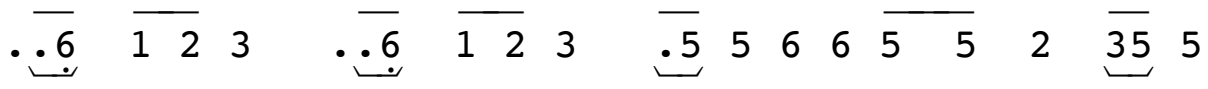

a-duh-sa-yang a- duh-sa-yang sa- tu ka-li ter-ba-yang-ba-yang

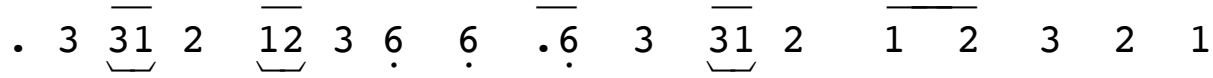

Pak-o-pak on-deon-de ge-lung pa-pak singa- yudhe-we

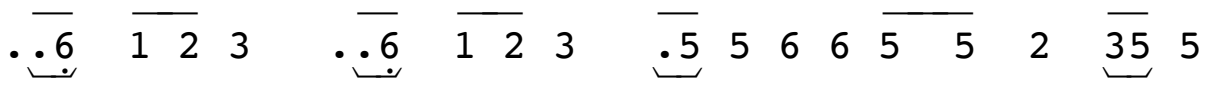

a-duh-sa-yang a-duh-sa-yang sa- tu ka-li ter-ba-yang-ba-yang

4) Terang Bulan

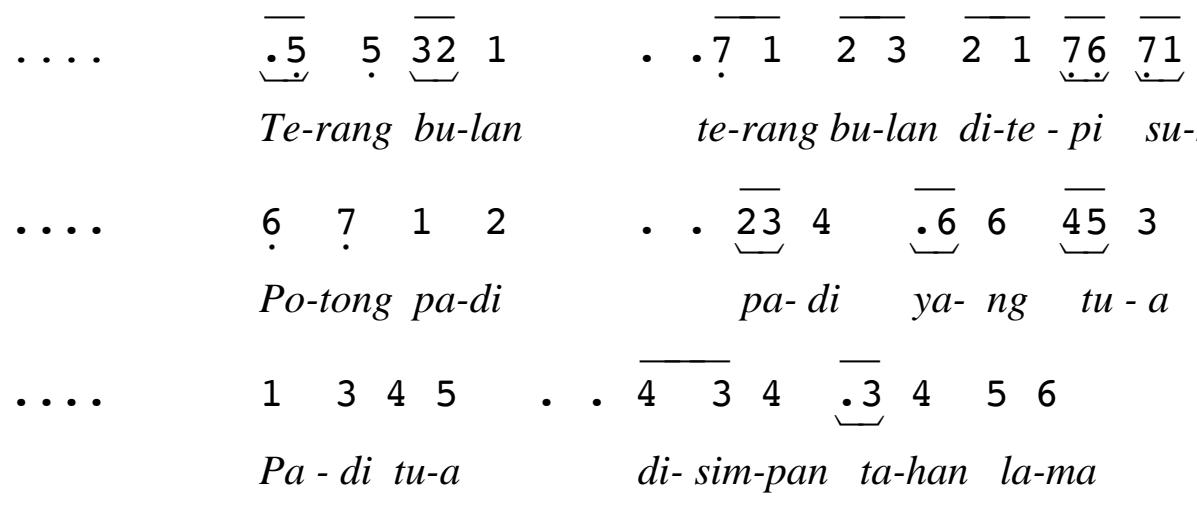




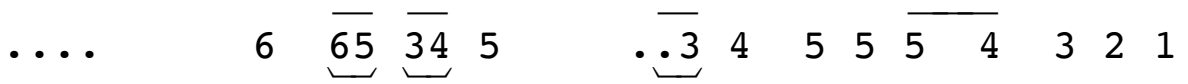

$$
\begin{aligned}
& \text { La-ma la-ma pa-di i- tuba-nyak gu-na-nya }
\end{aligned}
$$

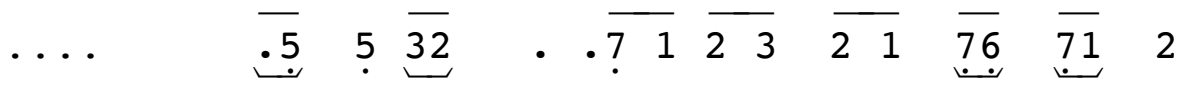

$$
\begin{aligned}
& \text { Gu- na-nya pa-di i-tu un-tuk ma- nu- sia }
\end{aligned}
$$

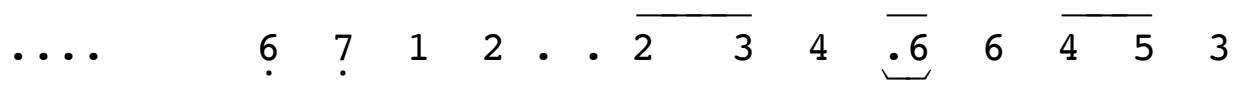

$$
\begin{aligned}
& \text { Ma-nu- si-a sam-pai da-pat yang sem-pur-na }
\end{aligned}
$$

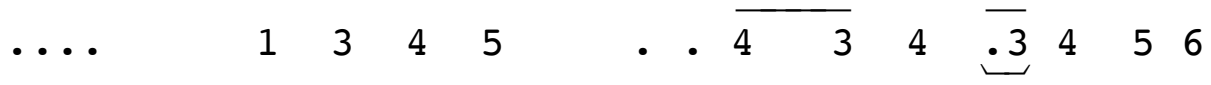

$$
\begin{aligned}
& \text { Sem-pur-na-nya ter-serah yang Ma-ha E-sa } \\
& \begin{array}{lllllllllllll}
\ldots & 6 & \overline{6} & 5 & \overline{34} & 5 & . .3 & 4 & 5 & \overline{54} & 3 & 2 & 1
\end{array} \\
& \text { Yang Ma-ha E-sa te-tap tu-ju-an ki-ta }
\end{aligned}
$$

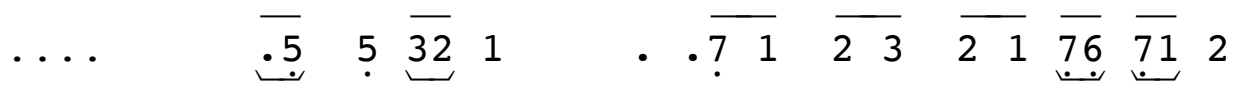

$$
\begin{aligned}
& \text { Te-rang bu-lan te-rang bu-lan di-te-pi su-ngai }
\end{aligned}
$$

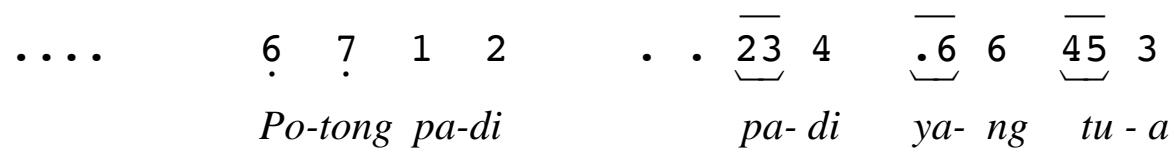

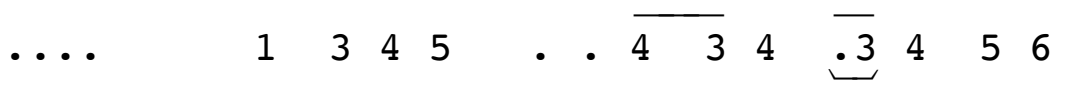

$$
\begin{aligned}
& \text { Pa-di tu-a di-sim-pan ta-han la-ma }
\end{aligned}
$$

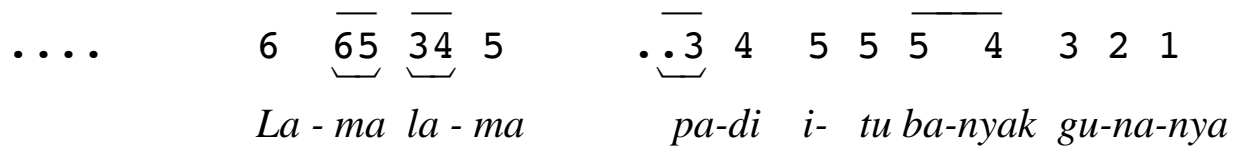

$$
\begin{aligned}
& \begin{array}{llllllllllll}
\ldots & \overline{5} & 5 & \overline{32} & \cdot .7 & \overline{2} & 3 & \overline{2} & \overline{76} & \overline{71} & 2
\end{array} \\
& \text { Gu- na-nya pa-di i-tu un-tuk ma- nu- sia }
\end{aligned}
$$

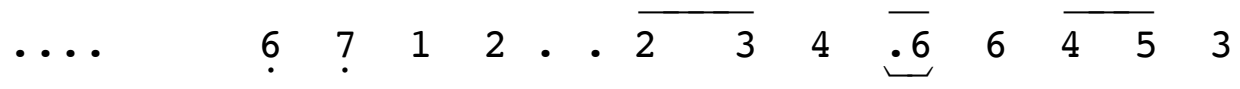

$$
\begin{aligned}
& \text { Ma-nu- si-a sam-pai da-pat yang sem-pur-na }
\end{aligned}
$$

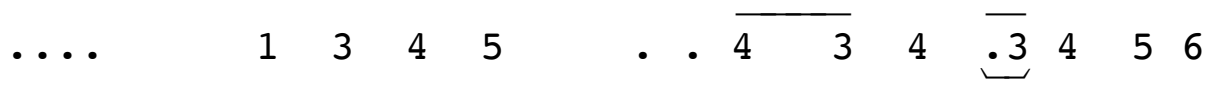

$$
\begin{aligned}
& \text { Sem-pur-na-nya ter-serah yang Ma-ha E-sa }
\end{aligned}
$$

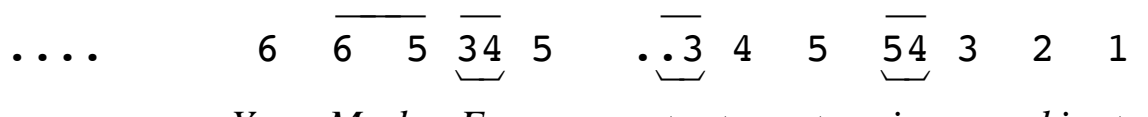

$$
\begin{aligned}
& \text { Yang Ma-ha E-sa te-tap tu-ju-an ki-ta }
\end{aligned}
$$


5) Bunga Rampai

$$
\begin{aligned}
& \text { - } \overline{.5} \overline{35} \quad \mathrm{i} \cdot \overline{.5} \overline{35} 2 \cdot \overline{.5} \overline{35} \quad \mathrm{i} \cdot \overline{.5} \overline{35} 2 \\
& \text { Bu-nga-ram-pai da-ri Ba-li Bu-nga-ram-pai da-ri Ba-li }
\end{aligned}
$$

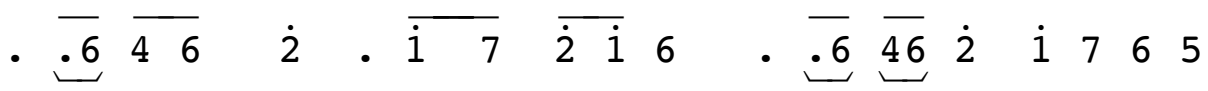

$$
\begin{aligned}
& \text { Bu-nga-ra- u ma-war me-la-ti ber-ma-in su-cimur-ni }
\end{aligned}
$$

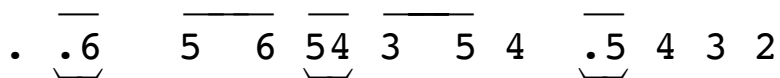

Tanda ma-ta yang ku-cin-ta da- ri Ba-li

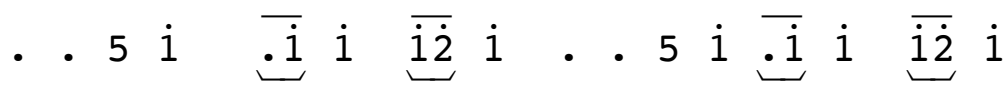

Ja-uh ma-lam si-ang ja-uh ma-lam si-ang

$\begin{array}{llll}.51 & 7 \overline{65} \quad \overline{45} 3\end{array}$

Sa-pu tangan yang ha-rum

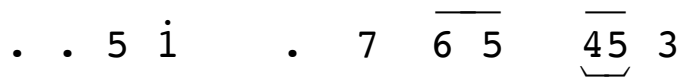

Sa-pu tangan yang ha-rum

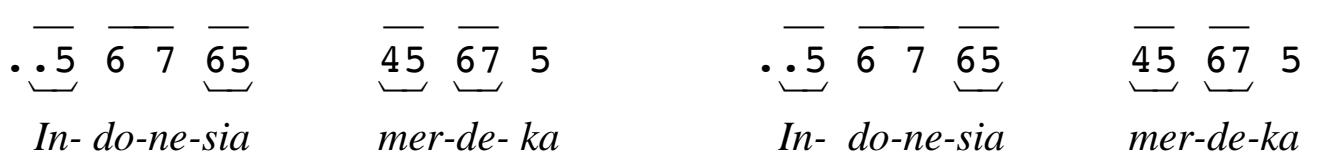

- . $\overline{67} 5 \quad \bar{i} \quad 2$ i 5

Mer-de-ka te-tap mer-de-ka

Pola permainan ketipung dan bass drum pada setiap perpindahan dari bagian 1 ke bagian selanjutnya, yaitu:

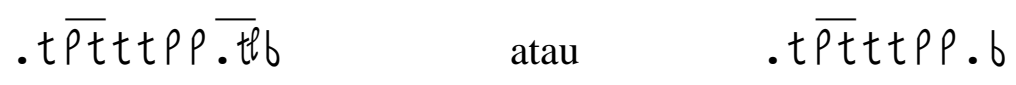

(Sumber: Aris Salamun, 22 Januari 2017)

Berdasarkan syair dari 4 judul iringan Tari Opak Abang yang telah disebutkan, maka dapat diketahui bahwa maksud dari lagu pertama yang berjudul Gayung Seribu Gayung ialah mengajak manusia untuk berbagi kepada sesama 
ketika sedang mendapat banyak keuntungan. Ajakan untuk berbagi kepada sesama disampaikan lewat pantun yang terdapat dalam syair lagu Gayung Seribu Gayung, sedangkan bagian Opak-Opak menceritakan tentang seorang pria yang sedang kasmaran seperti pernyataan Bapak Aris Salamun (2 Mei 2017).

"Di bagian Opak-Opak isinya tentang seorang pria yang kasmaran dengan seorang perempuan"

Berdasarkan hasil wawancara dengan Bapak Aris Salamun tanggal 2 Mei 2017, lagu kedua Opak-Opak merupakan rangkaian pantun yang menceritakan tentang seorang lelaki yang terpesona dan jatuh cinta dengan seorang wanita cantik yang rambutnya disanggul dengan rapi. Laki-laki itu sangat terpesona, sehingga berupaya mengejar wanita idamannya namun sang wanita menghindar, sehingga laki-laki itu menjadi sedih dan sering menyendiri seperti orang yang sebatang kara. Judul lagu yang ketiga, Terang Bulan berisi tentang petuah untuk manusia agar senantiasa menjadikan Tuhan Yang Maha Esa sebagai tujuan hidup, selain itu, pada lagu Terang Bulan juga memuat tentang betapa pentingnya tumbuhan padi bagi kehidupan, karena warga Desa Pasigitan mayoritas bekerja sebagai petani. Terakhir, lagu berjudul Bunga Rampai menjelaskan tentang keindahan bunga-bunga dari Bali yang merupakan salah satu pulau paling indah di Indonesia, selain itu pada lagu ini juga berisi informasi tentang kemerdekaan Indonesia sehingga memberi semangat patriotisme bagi warga Desa Pasigitan.

\subsubsection{Tata Pentas Tari Opak Abang}

Pada saat peneliti sedang melakukan pengamatan, Tari Opak Abang dipentaskan pada halaman depan rumah salah satu warga Desa Pasigitan, yaitu 
Bapak Aris Salamun. Area pertunjukan diberi alas dua buah karpet merah berbentuk persegi. Tari Opak Abang apabila sedang mengisi acara hajatan di Desa Pasigitan biasa dipentaskan di arena terbuka atau halaman yang luas seperti pada foto 4.63 .

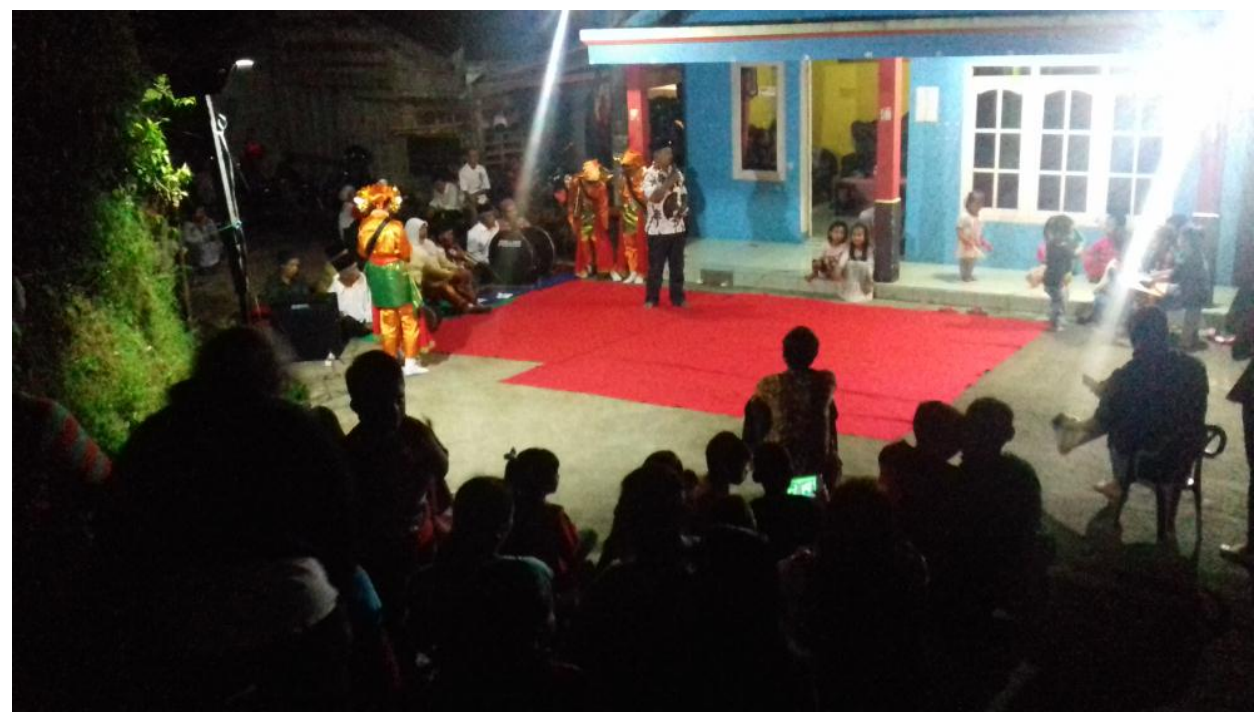

Foto 4.63. Area Pertunjukan Tari Opak Abang (Sumber: Dokumentasi Mawasti, 22 April 2017)

Foto 4.63. menunjukan pementasan Tari Opak Abang pada tanggal 22 April 2017 pukul 20:30 di halaman depan kediaman Bapak Aris Salamun selaku ketua paguyuban Sri Langen Budaya Bumi. Halaman rumah Bapak Aris Salamun dipilih sebagai tempat pementasan karena dinilai luas, strategis, dan memiliki akses yang mudah bagi para warga yang ingin menonton pertunjukan Tari Opak Abang.

\subsubsection{Tata Lampu/Pencahayaan Tari Opak Abang}

Tari Opak Abang pada pementasannya menggunakan pencahayaan General. General dapat dijelaskan sebagai pola pencahayaan yang tidak memunculkan suatu keadaan atau suasana tertentu karena Tari Opak Abang merupakan tarian 
tanpa alur cerita. Pencahayaan General tidak menggunakan lampu yang berwarnawarni, tetapi hanya 1 warna saja, misalnya warna putih seperti pada foto 4.64 .

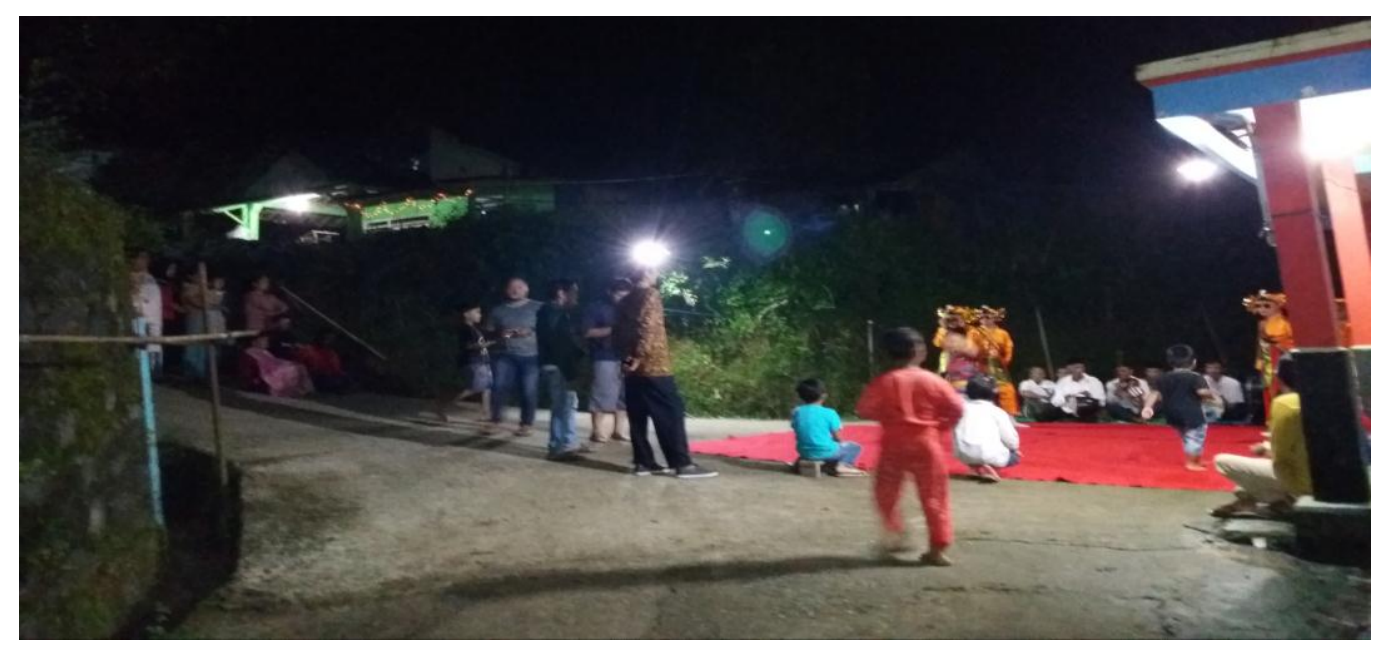

Foto 4.64. Lampu yang digunakan pada Pertunjukan Tari Opak Abang (Sumber: Dokumentasi Mawasti, 22 April 2017)

Berdasarkan foto 4.64. tata pencahayaan Tari Opak Abang menggunakan General light (terletak di sudut kiri belakang dan kanan depan area pertunjukan) karena tidak menonjolkan suasana atau kondisi tertentu dalam pementasannya. Pencahayaan pertunjukan Tari Opak Abang selain menggunakan dua lampu General, juga menggunakan satu buah lampu bohlam berwarna putih yang diletakkan tepat di atas karpet merah sebagai area pementasan Tari Opak Abang. Pencahayaan pertunjukan Tari Opak Abang dijelaskan oleh Bapak Aris Salamun (22 April 2017) melalui penuturannya berikut.

"Pencahayaannya pakai lampu rumah dan lampu sorot warna putih yang di pasang di sudut-sudut area pertunjukan".

Berdasarkan wawancara dengan Bapak Aris Salamun pada tanggal 22 April 2017, pencahayaan yang digunakan pada pementasan Tari Opak Abang di Desa 
Pasigitan tanggal 22 April 2017 menggunakan 1 buah lampu bohlam putih, dan dua buah lampu General milik Bapak Aris Salamun.

\subsubsection{Tata Suara Tari Opak Abang}

Pementasan Tari Opak Abang menggunakan sound system dan speaker yang memiliki volume suara cukup besar agar iringan musik dapat terdengar oleh para penari maupun penonton. Berikut adalah wireless microphone yang digunakan dalam pertunjukan Tari Opak Abang seperti pada foto 4.65.

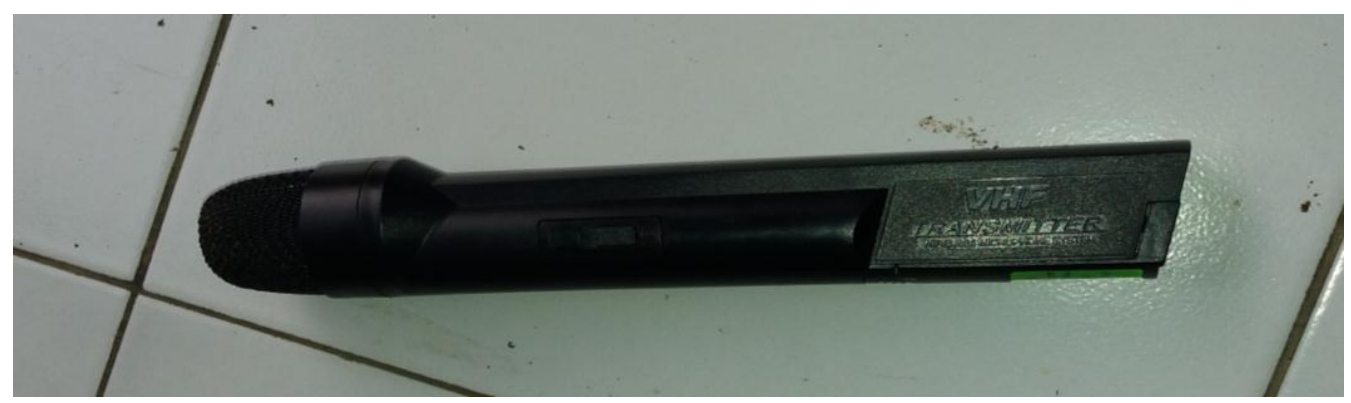

Foto 4.65. Wireless Microphone

(Sumber: Dokumentasi Mawasti, 22 April 2017

Foto 4.65. memperlihatkan wireless microphone yang digunakan oleh sindhen dalam pertunjukan Tari Opak Abang di Desa Pasigitan. Wireless microphone merupakan microphone tanpa kabel yang biasa digunakan oleh sindhen untuk menyanyi pada pertunjukan Tari Opak Abang. Penggunaan wireless microphone menurut Bapak Aris Salamun lebih efektif, karena tidak perlu menggulung dan mengulur kabel, sehingga mempersingkat waktu untuk persiapan pertunjukan maupun penataan kembali saat pertunjukan selesai. 
Berikut adalah foto 4.66. yang menunjukan saat sindhen sedang menggunakan wireless microphone untuk bernyanyi.

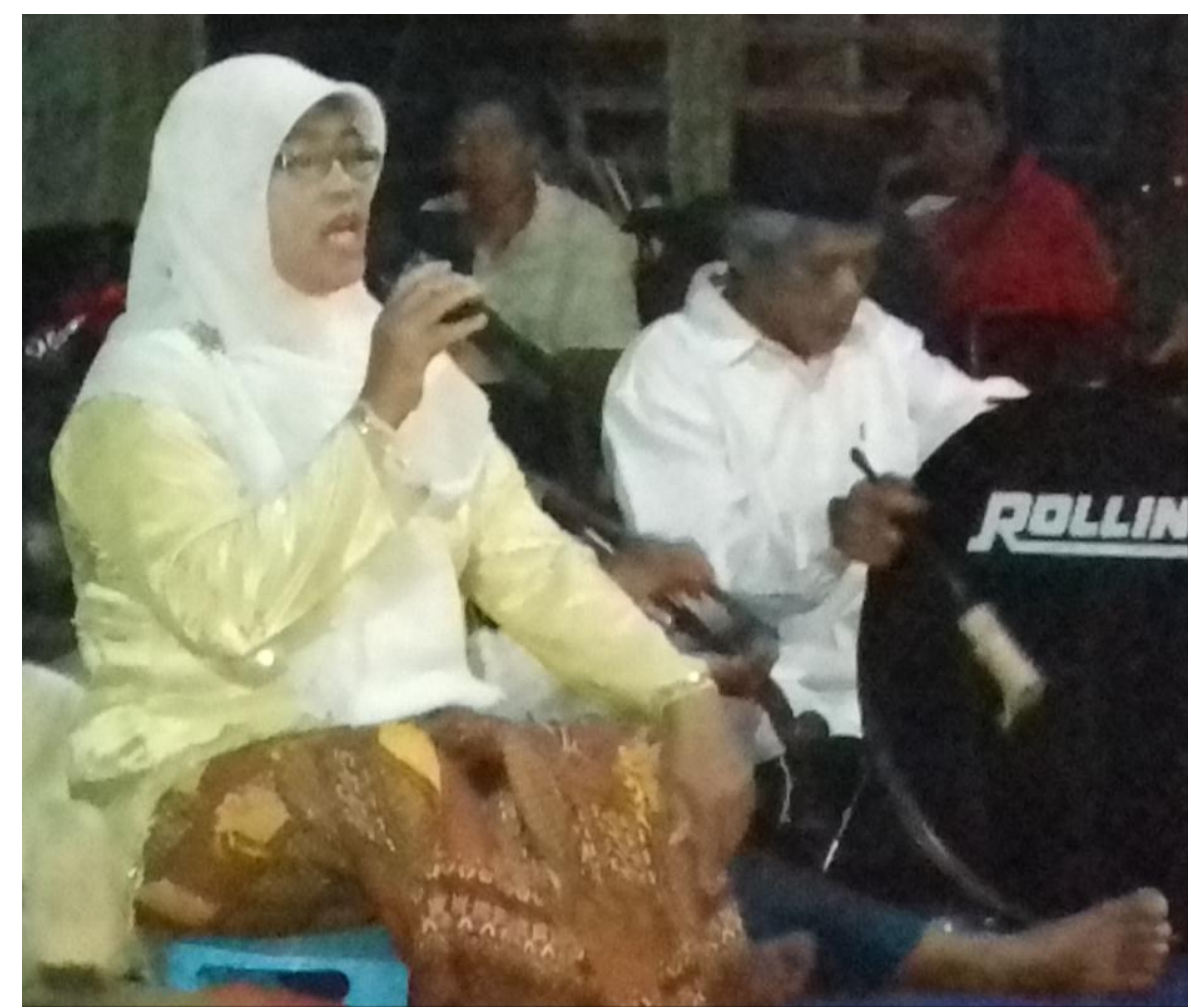

Foto 4.66. Sindhen menggunakan wireless microphone

(Sumber: Dokumentasi Mawasti, 22 April 2017)

Foto 4.66. menunjukkan ketika sindhen sedang tampil menyanyi dengan menggunakan wireless microphone. Wireless microphone sengaja digunakan karena praktis tanpa memakai kabel, penata sound system tidak perlu susah payah menghubungkan kabel microphone ke aliran listrik, karena wireless microphone menggunakan baterei untuk dayanya, selain itu suara yang dihasilkan oleh wireless microphone keras dan jelas. 
Tari Opak Abang menggunakan wireless dalam sound system pertunjukan, seperti pada foto 4.67 .

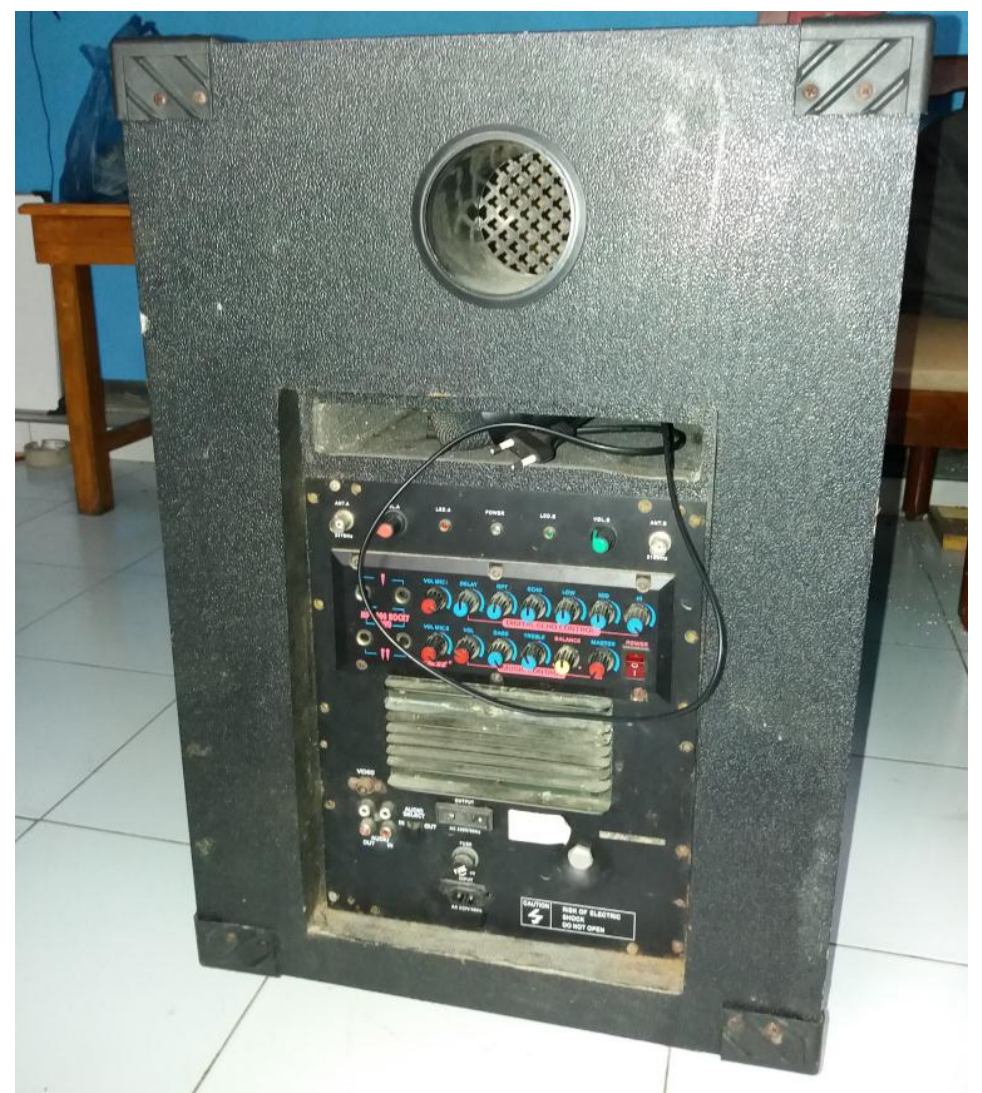

Foto 4.67. Wireless

(Sumber: Dokumentasi Mawasti, 22 April 2017)

Foto 4.67. menunjukan wireless yang digunakan untuk sound system pertunjukan Tari Opak Abang. Wireless merupakan speaker penyalur suara dari wireless microphone yang digunakan oleh sindhen ketika menyanyikan iringan Tari Opak Abang. Wireless digunakan karena lebih praktis dan tidak memakan tempat, selain itu suara yang dihasilkan oleh wireless terdengar keras dan jelas. 
Berikut keyboard amplifier yang digunakan dalam sound system Tari Opak Abang, seperti pada foto 4.68 .

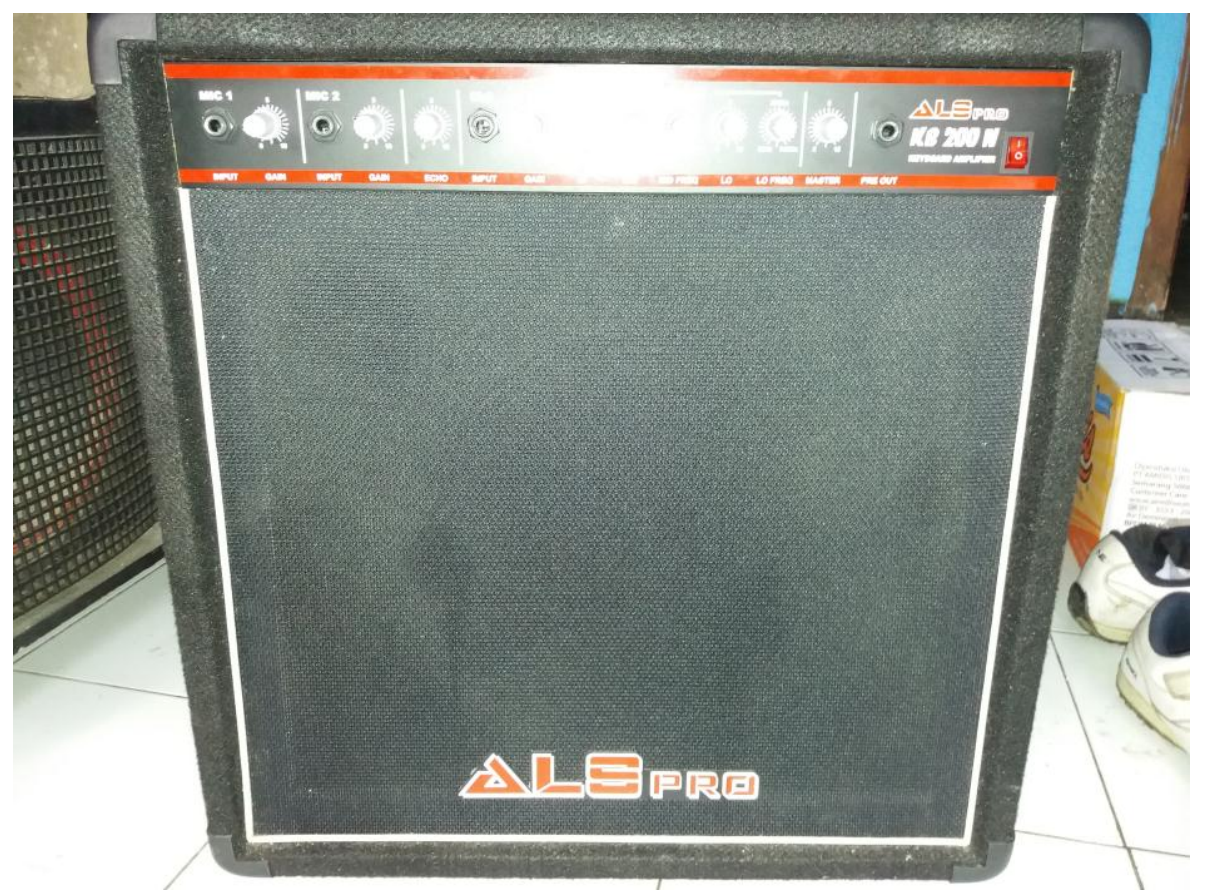

Foto 4.68. Keyboard Amplifier

(Sumber: Dokumentasi Mawasti, 22 April 2017)

Pada foto 4.68. terlihat perlengkapan tata suara dalam pertunjukan Tari Opak Abang, yaitu keyboard amplifier. Keyboard amplifier pada pertunjukan Tari Opak Abang di kediaman Bapak Aris Salamun berfungsi sebagai penyalur suara dari alat musik biola yang digunakan untuk iringan Tari Opak Abang saat pertunjukan berlangsung sebagaimana penuturan dari Bapak Aris Salamun (22 April 2017).

"Pertunjukan Tari Opak Abang perlu memakai sound system untuk suara iringan agar lebih keras dan jelas Sound system yang digunakan untuk pentas di sini memakai sound wireless untuk microphone sindhen, dan keyboard amplifier untuk biola." 
Berdasarkan hasil wawancara dengan Bapak Aris Salamun pada tanggal 22 April 2017, penggunaan sound system berupa wireless, keyboard amplifier dan wireless microphone sangat diperlukan karena pertunjukan Tari Opak Abang dilakukan di area terbuka yang luas sehingga dapat membantu mengeraskan suara iringan dan sindhen agar dapat terdengar oleh penari dan penonton.

\subsubsection{Pelaku Tari Opak Abang}

Tari Opak Abang dipentaskan dengan jumlah minimal 4 orang penari, pada penampilannya di pentas hiburat masyarakat Desa Pasigitan pada tanggal 22 April 2017 yang dibawakan oleh 4 penari wanita dan 7 pengiring, seperti yang terlihat pada foto 4.69 .

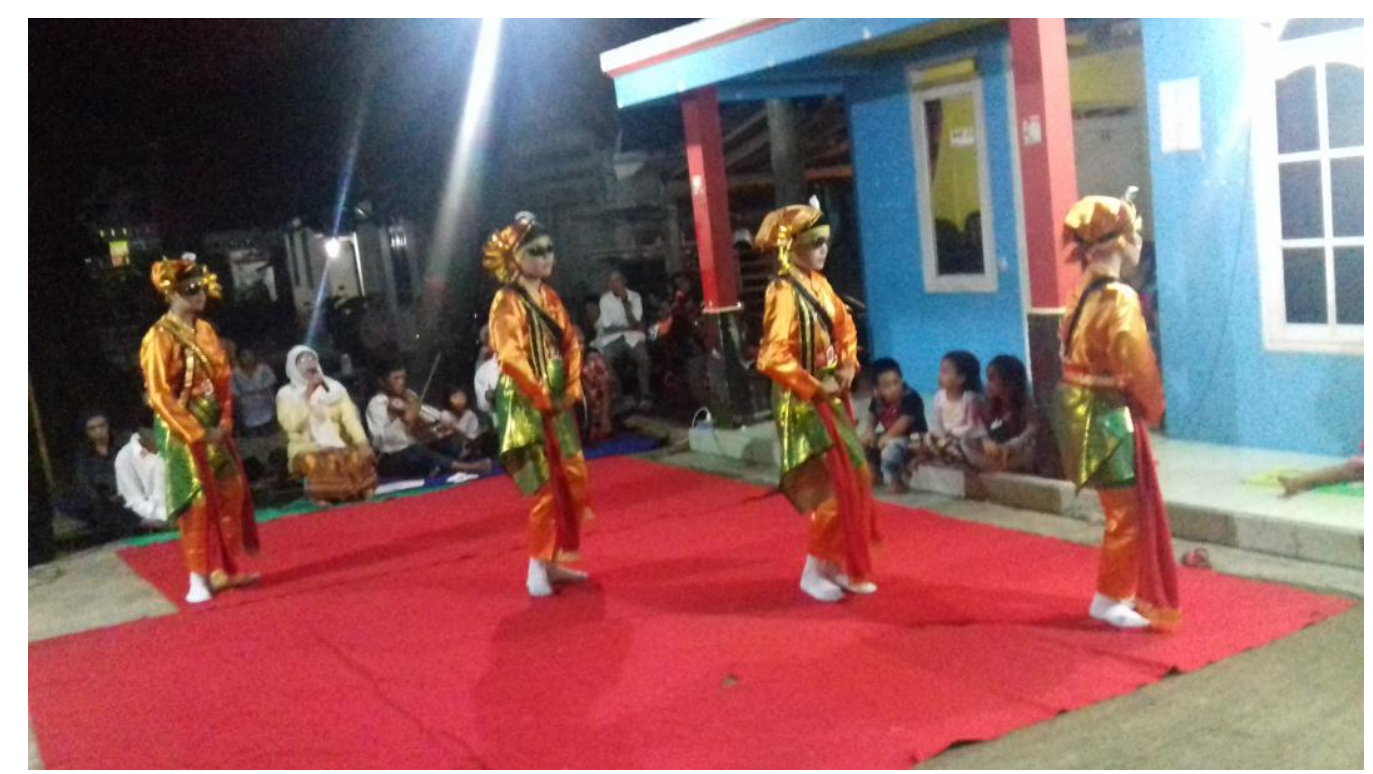

Foto 4.69. Pelaku Pertunjukan Tari Opak Abang (Sumber: Dokumentasi Mawasti, 22 April 2017)

Berdasarkan foto 4.69. pelaku seni pertunjukan Tari Opak Abang berjumlah 11 orang, dengan rincian penari 4 orang, pemusik 6 orang, dan sindhen 1 orang. 
Penari Tari Opak Abang berasal dari rentang usia yang berbeda, 3 orang penari rentang usia sekitar 13-18 tahun, sedangkan 1 orang penari berusia 35 tahun. Pemusik dan sindhen Tari Opak Abang rentang usianya sekitar 35 sampai dengan 65 tahun.

\subsubsection{Penonton Pertunjukan Tari Opak Abang}

Penonton yang melihat pementasan Tari Opak Abang berasal dari semua kalangan, tidak hanya dari penikmat seni, melainkan juga dari masyarakat awam, akan tetapi mayoritas penonton berasal dari Desa Pasigitan. Tari Opak Abang sebagai tari rakyat yang pernah dipentaskan dalam acara daerah maupun nasional tentu memiliki daya tarik sendiri bagi para penonton yang melihatnya. Berikut adalah pendapat dari beberapa narasumber yang telah diwawancarai oleh peneliti mengenai kesan dan pesan setelah menonton pertunjukan Tari Opak Abang. Ibu Siamah (22 April 2017) menyatakan kesan pesan setelah menonton pertunjukan Tari Opak Abang.

"Saya senang sekali melihat pertunjukan Tari Opak Abang, menarik, selain itu saya dulu juga pernah ikut Tari Opak Abang ketika masih muda. Seharusnya kesenian seperti Tari Opak Abang tetap dipertahankan agar maju."

Berdasarkan keterangan dari Ibu Siamah pada tanggal 22 April 2017, Ibu Siamah merasa senang ketika menyaksikan pertunjukan Tari Opak Abang, beliau teringat kembali dengan masa mudanya yang pernah ikut menarikan Opak Abang. Harapan Ibu Siamah untuk pertunjukan Tari Opak Abang agar tetap dipertahankan. Pertunjukan Tari Opak Abang terbukti masih mempunyai daya tarik untuk menghibur penonton yang didominasi oleh masyarakat Desa Pasigitan. 
Tari Opak Abang membuat penonton merasa senang dan puas ketika menyaksikan pertunjukan. Senada dengan pernyataan Ibu Siamah, berikut penuturan Ibu Purwati (22 April 2017) usai menyaksikan pertunjukan Tari Opak Abang.

"Ketika melihat pertunjukan Tari Opak Abang saya merasa senang, harapannya supaya Tari Opak Abang tetap baik dan tidak hilang."

Ibu Purwati pada tanggal 22 April 2017 menyatakan bahwa dirinya merasa senang ketika menyaksikan pertunjukan Tari Opak Abang. Ibu Purwati berharap agar Tari Opak Abang tidak hilang, karena pertunjukannya sangat menarik. Pertunjukan tari yang menarik tidak lepas dari kemampuan penari dalam menyajikan tarian yang didukung oleh pemusik, sesuai dengan penuturan dari Nimas Agustin (22 April 2017) berikut.

"Pertunjukannya menarik, untuk para penarinya agar lebih memperhatikan pola lantai, dan pemusiknya sudah banyak yang berumur maka lebih baik bila ada regenerasi."

Berdasarkan hasil wawancara dengan Nimas Agustin pada tanggal 22 April 2017, Nimas Agustin menyebutkan bahwa pertunjukan Tari Opak Abang menarik, akan tetapi para penari harus memperhatikan pola lantai yang digunakan, selain itu karena para pemusik yang sudah lanjut usia hendaknya diadakan regenerasi agar Tari Opak Abang mempunyai generasi muda sebagai penerus.

Sesuai dengan hasil wawancara peneliti dengan 3 narasumber yang berbeda latar belakangnya, maka peneliti dapat menarik sebuah simpulan mengenai kesan dan pesan penonton terhadap pertunjukan Tari Opak Abang di Desa Pasigitan, bahwa pertunjukan Tari Opak Abang menarik dan dapat menghibur penonton. 
Narasumber berharap agar Tari Opak Abang dapat selalu terjaga orisinalitas tariannya dan tetap dilestarikan sampai kapanpun.

Berikut foto 4.70. yang memperlihatkan para penonton ketika sedang menikmati pertunjukan Tari Opak Abang.

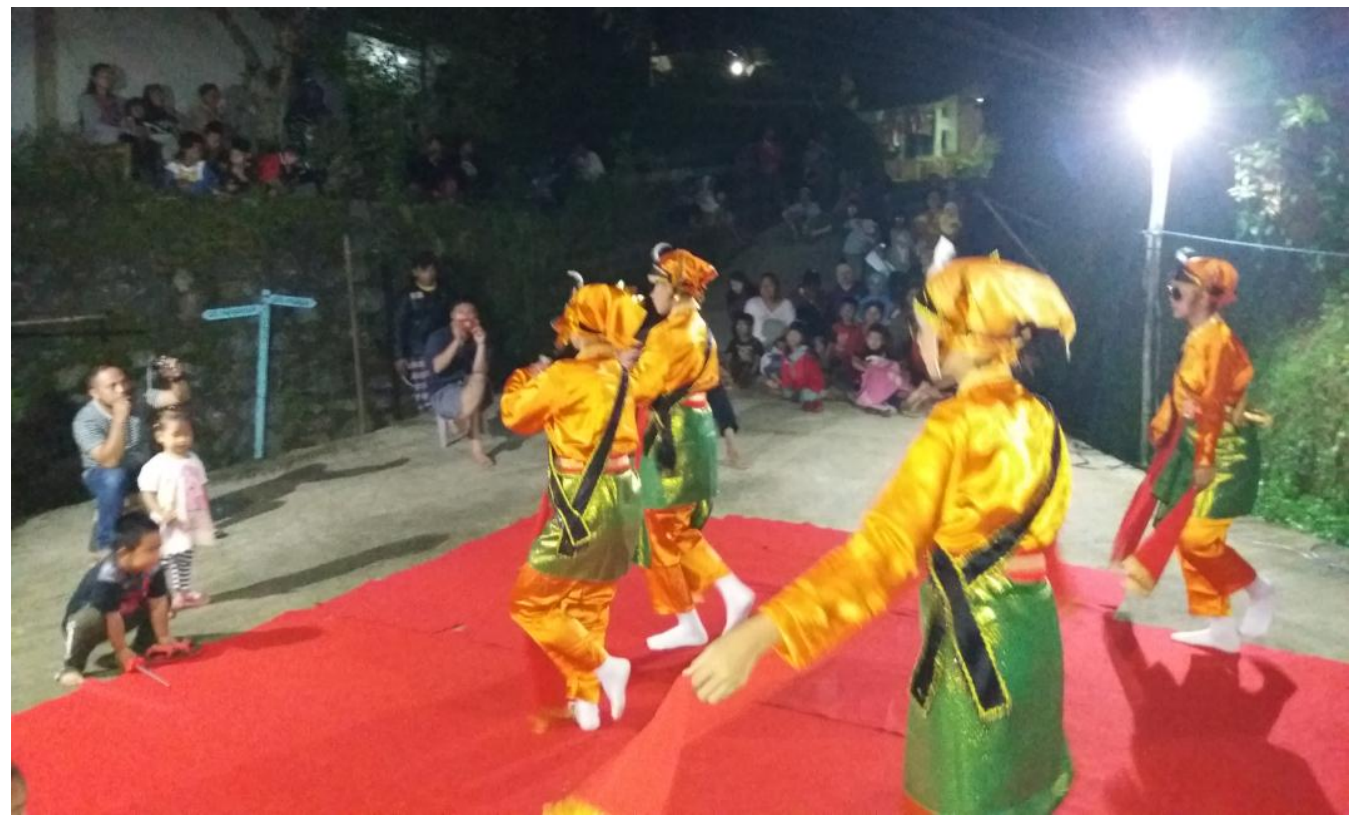

Foto 4.70. Penonton pertunjukan Tari Opak Abang

(Sumber: Dokumentasi Mawasti, 22 April 2017)

Pada foto 4.70. terlihat penonton yang terabadikan oleh kamera sedang duduk dan menonton pertunjukan Tari Opak Abang di depan kediaman Bapak Aris Salamun. Mayoritas penonton dipenuhi oleh warga Desa Pasigitan, namun ada pula beberapa penonton berasal dari luar lingkungan Desa Pasigitan yang sengaja melihat pertunjukan Tari Opak Abang. 


\subsection{Perubahan Fungsi Pertunjukan Tari Opak Abang}

Pada awal kemunculan Tari Opak Abang tahun 1956 sampai dengan awal tahun 1980, Tari Opak Abang berfungsi sebagai syiar agama Islam sekaligus media informasi kemerdekaan Indonesia karena banyak warga Desa Pasigitan yang belum mengetahui tentang agama Islam dan informasi tentang kemerdekaan Indonesia sebab dulu belum ada sarana informasi yang memadai serta banyak masyarakat Desa Pasigitan yang buta huruf.

Tari Opak Abang berfungsi sebagai syiar agama Islam yang terlihat jelas pada penggalan liriknya, yaitu:

Terang Bulan... Terang Bulan di tepi sungai...

Potong padi...padi yang tua...

Padi tua disimpan tahan lama...

Lama-lama padi itu banyak gunanya...

Gunanya ... padi itu untuk manusia...

Manusia sampai dapat yang sempurna..

Sempurnanya terserah Yang Maha Esa...

Yang Maha Esa ... tetap tujuan kita...

makna: kesempurnaan hanya milik Tuhan Yang Maha Esa, sehingga kita harus selalu menjadikan Tuhan sebagai tujuan hidup kita. Penggalan lirik di atas bermaksud untuk mengajak manusia agar selalu ingat kepada Tuhan Yang Maha Esa.

Bukti Tari Opak Abang berfungsi sebagai syiar agama Islam juga terlihat pada tata busana yang menggunakan kain penutup kepala atau bisa disebut dengan 
kerudung, baju lengan panjang, celana panjang, dan kain songket, hal ini menggambarkan bahwa Tari Opak Abang memiliki ciri khas melayu dan digunakan sebagai media syiar agama Islam.

Tari Opak Abang berfungsi untuk menegaskan bahwa Indonesia telah merdeka melalui penggalan lirik berikut:

Jauh malam siang...

Sapu tangan yang harum...

Indonesia merdeka...

Merdeka tetap merdeka...

makna: penggalan lirik di atas bermaksud menjelaskan bahwa Indonesia telah merdeka, mengobarkan semangat patriotisme warga Indonesia melalui kata-kata “Merdeka tetap Merdeka”, dan dulunya bertujuan untuk menyebarkan informasi kemerdekaan Indonesia.

Pada awal tahun 1980 hingga tahun 2017, Tari Opak tidak lagi dijadikan untuk syiar agama Islam, karena berdasarkan data statistik daerah Desa Pasigitan di tahun 2016 menyebutkan bahwa $100 \%$ penduduk Desa Pasigitan telah menganut agama Islam, sehingga fungsi sebagai syiar agama Islam telah berubah menjadi sarana hiburan masyarakat, begitu pula dengan fungsi media informasi seputar kemerdekaan Indonesia. Awal tahun 1980, perkembangan teknologi dan informasi di Desa Pasigitan cukup baik dan sudah banyak masyarakat Desa Pasigitan yang bisa membaca, sehingga informasi mengenai kemerdekaan Indonesia sudah didapat dari koran, surat kabar, maupun alat elektronik seperti radio. Tahun 2017, seluruh informasi tentang Negara Indonesia dapat diakses oleh 
masyarakat Desa Pasigitan tidak hanya dari koran, radio, tetapi juga dari televisi, dan internet. Fungsi pertunjukan Tari Opak Abang mulai dari awal tahun 1980 sampai tahun 2017 berubah menjadi sarana hiburan, namun pada akhir tahun 1980 dan tahun 2016, fungsi Tari Opak Abang di Desa Pasigitan sempat berubah menjadi sarana pertunjukan, akan tetapi pada tahun 2017 Tari Opak Abang kembali menjadi sarana hiburan. Masyarakat Desa Pasigitan biasa menampilkan pertunjukan Tari Opak Abang di acara-acara formal maupun semiformal seperti HUT Kabupaten Kendal, tirakatan 17 Agustus, dan hajatan yang diadakan oleh warga sebagai sajian hiburan baik di Desa Pasigitan maupun di luar Desa Pasigitan. Tari Opak Abang pada setiap pertunjukannya selalu menampilkan sajian yang dapat menghibur warga, sehingga setelah menonton pertunjukan warga akan merasa puas dan merasa senang karena terhibur oleh penampilan Tari Opak Abang, seperti penampilan Tari Opak Abang pada tanggal 22 April 2017, Tari Opak Abang dipentaskan kembali untuk pentas hiburan masyarakat Desa Pasigitan di halaman depan kediaman Bapak Aris Salamun.

Pada akhir tahun 1980, Tari Opak Abang pernah ditampilkan pada ajangajang seni pertunjukan tingkat daerah maupun tingkat nasional, seperti Festival Pertunjukan Rakyat Tingkat Karesidenan Semarang dan Tingkat Provinsi Jawa Tengah, selain itu Tari Opak Abang juga pernah ditampilkan di Anjungan Jawa Tengah Taman Mini Indonesia Indah. Pada Mei 2016, Tari Opak Abang berkesempatan melakukan kolaborasi dengan tempat wisata di Kabupaten Kendal, yaitu Santosa Stable untuk menampilkan suatu pertunjukan kethoprak dengan membawakan cerita rakyat Boja yaitu Nyai Dapu, yang mana Tari Opak Abang 
dijadikan sebagai sajian pembuka. Tari Opak Abang sebagai seni pertunjukan pernah turut memeriahkan panggung jurusan Seni Drama, Tari, dan Musik tepatnya dalam acara Pesona Tari Jateng tanggal 16 Januari tahun 2016 yang diadakan oleh mahasiswa program studi Pendidikan Seni Tari Universitas Negeri Semarang. Pada tahun 2016, Tari Opak Abang hanya 3 kali pentas yaitu pada acara pertunjukan Pesona Tari Jateng 2016, pertunjukan di Santosa Stable pada Bulan Mei, dan Bulan November pada acara peringatan Hari Lansia, karena permintaan dari masyarakat kepada Tari Opak Abang untuk sajian hiburan di acara hajatan mulai berkurang, sehingga dapat dikatakan pada akhir tahun 1980 dan tahun 2016 Tari Opak Abang telah mengalami perubahan fungsi dari sarana hiburan, menjadi sarana pertunjukan.

Tari Opak Abang pada tahun 1995 menjadi bagian dalam ritual sedekah bumi yang diadakan oleh Kabupaten Kendal. Pada ritual sedekah bumi, Tari Opak Abang menjadi sajian tari yang turut mendukung jalannya ritual, akan tetapi pada pertunjukan Tari Opak Abang sendiri tidak menggunakan sesaji ataupun ritual khusus. Berikut keterangan Bapak Aris Salamun (30 Januari 2017) mengenai Tari Opak Abang yang dipentaskan dalam ritual sedekah bumi.

"Tari Opak Abang tahun 1995 ditampilkan di ritual sedekah bumi Kabupaten Kendal, tetapi di tahun-tahun berikutnya sampai sekarang tahun 2017 ritual sedekah bumi sudah tidak pernah dilaksanakan, karena masyarakat sudah berkurang minatnya dan seleranya sudah berubah".

Berdasarkan wawancara dengan Bapak Aris Salamun tanggal 30 Januari 2017, ritual sedekah bumi awalnya rutin diadakan setiap tahunnya oleh masyarakat Kabupaten Kendal, namun seiring berjalannya waktu hingga tahun 
1995, ritual sedekah bumi Kabupaten Kendal kini sudah tidak pernah dilaksanakan, sehingga Tari Opak Abang mulai tahun 1996 sampai tahun 2017 tidak lagi tampil dalam ritual sedekah bumi. Penyebab ritual sedekah bumi dihentikan adalah, karena masyarakat Desa Pasigitan telah mengikuti perkembangan zaman dan teknologi, sehingga pola pikir masyarakat Desa Pasigitan sudah lebih maju dan penganut animisme dan dinamisme mulai berkurang. Minat masyarakat Kabupaten Kendal khususnya Desa Pasigitan terhadap ritual sedekah bumi telah berkurang, sebagai gantinya masyarakat lebih suka melihat pertunjukan musik seperti dangdut daripada menyaksikan ritual sedekah bumi.

Berdasarkan uraian yang telah disebutkan mengenai fungsi seni pertunjukan Tari Opak Abang, tahun 1956 berfungsi sebagai syiar agama Islam dan media informasi kemerdekaan Indonesia, akan tetapi memasuki awal tahun 1980 hingga tahun 2017 fungsi seni pertunjukan Tari Opak Abang berubah menjadi sarana hiburan masyarakat karena banyak masyarakat yang sudah mengenal Tari Opak Abang dan kemudian menampilkannya sebagai sajian hiburan di berbagai acara, akan tetapi pada akhir tahun 1980 dan tahun 2016, Tari Opak Abang sempat mengalami perubahan fungsi menjadi sarana pertunjukan karena pada akhir tahun 1980 Tari Opak Abang mengikuti Festival Pertunjukan Rakyat tingkat karesidenan dan tingkat nasional, kemudian pada awal tahun 2016 tampil dalam acara Pesona Tari Jawa Tengah 2016 di Universitas Negeri Semarang, dilanjut pada bulan Mei tahun 2016 tampil di Santosa Stable, dan terakhir bulan November tahun 2016 tampil dalam rangka memperingati Hari Lansia. Pada tahun 
1996 sampai dengan tahun 2017, Tari Opak Abang tidak lagi menjadi bagian dari ritual sedekah bumi di Kabupaten Kendal, karena pelaksanaan ritual sedekah bumi dihentikan akibat perubahan kepercayaan masyarakat Desa Pasigitan yang tidak lagi menganut animisme dan dinamisme serta perubahan selera masyarakat yang lebih suka menonton pertunjukan musik dangdut daripada menyaksikan ritual sedekah bumi, sehingga dapat diketahui bahwa fungsi pertunjukan Tari Opak Abang banyak mengalami perubahan dari tahun 1956 hingga tahun 2017, sebagai syiar agama dan media informasi kemerdekaan menjadi sarana hiburan, sarana hiburan menjadi sarana pertunjukan, sarana hiburan menjadi sarana upacara ritual, sarana ritualkembali menjadi sarana hiburan, sarana hiburan kembali menjadi sarana pertunjukan, dan terakhir sarana pertunjukan kembali menjadi sarana hiburan. 


\section{BAB V \\ PENUTUP}

\subsection{Simpulan}

Berdasarkan hasil penelitian mengenai Bentuk dan Fungsi Pertunjukan Tari Opak Abang Desa Pasigitan Kecamatan Boja Kabupaten Kendal, dapat diketahui bahwa struktur pertunjukan Tari Opak Abang ada 3, yaitu: 1) awal pertunjukan; 2) inti pertunjukan; dan 4) akhir pertunjukan. Awal pertunjukan diisi dengan sambutan pembuka ketua grup Sri Langen Budaya Bumi dilanjut dengan gerak Lambeyan sebagai pembuka Tari Opak Abang. Bagian inti pertunjukan pada Tari Opak Abang ada 4, yaitu: 1) Gayung Seribu Gayung; 2) Opak-Opak; 3) Terang Bulan; dan 4) Bunga Rampai. Terakhir, bagian akhir pertunjukan berisi gerak Lambeyan akhir penari Opak Abang lalu ditutup dengan ketua grup Sri Langen Budaya Bumi. Gerak Tari Opak Abang menggunakan gerak murni karena hanya mengutamakan nilai keindahan dari gerak tanpa ada maksud tertentu. Tata rias Tari Opak Abang menggunakan rias korektif, dan tata busana Tari Opak Abang menggunakan kostum serta atribut, yaitu : 1) Plisir (irah-irahan) dengan bulu mentok di ujung; 2) Selempang; 3) Slepe (sabuk); 4) Baju lengan panjang; 5)

Celana panjang; 6) Kaos kaki berwarna putih; 7) Kain songket; Sampur/Selendang; 9) Kipas dari kertas emas untuk telinga; 10) Kacamata hitam; dan 11) Kain penutup kepala. Iringan Tari Opak Abang menggunakan nada diatonis dengan alat-alat musik berupa bass drum 1 buah, rebana 2 buah, ketipung satu sisi 1 buah, kecrek 1 buah, dan biola/violin 1 buah. Pementasan Tari Opak Abang menggunakan halaman depan dari kediaman Bapak Aris Salamun di 
Dusun Siranti, Desa Pasigitan. Tata lampu pertunjukan Tari Opak Abang menggunakan general light dan lampu bohlam putih milik Bapak Aris Salamun. Tata suara pertunjukan Tari Opak Abang menggunakan sound system berupa wireless, keyboard amplifier, dan wireless microphone. Pelaku pertunjukan Tari Opak Abang ialah 4 orang penari wanita, 6 orang pemusik dan 1 orang sindhen. Penonton pertunjukan Tari Opak Abang berasal dari berbagai kalangan, dari yang awam hingga yang berkecimpung di dunia tari.

Kemajuan teknologi dan ilmu pengetahuan membuat fungsi-fungsi pertunjukan Tari Opak Abang mengalami perubahan. Tari Opak Abang awalnya sebagai syiar agama Islam dan media informasi kemerdekaan Indonesia, namun seiring berjalannya waktu dan teknologi informasi yang semakin berkembang, fungsi pertunjukan Tari Opak Abang berubah sebagai hiburan masyarakat, karena setelah banyak masyarakat yang mengetahui Tari Opak Abang, pertunjukan Tari Opak Abang biasa ditampilkan pada acara hajatan, HUT Kabupaten Kendal, dan tirakatan 17 Agustus dalam rangka memperingati kemerdekaan Indonesia. Fungsi Tari Opak Abang sempat berubah menjadi sarana pertunjukan dengan ditampilkannya Tari Opak Abang dalam festival-festival seni pertunjukan, karena pada akhir tahun 1980 dan sepanjang tahun 2016 permintaan untuk mengisi hajatan berkurang dan justru Tari Opak Abang lebih sering mengikuti festival pertunjukan tari. Pada tahun 1996 hingga tahun 2017, fungsi Tari Opak Abang sebagai sarana ritual dalam sedekah bumi berubah menjadi sarana hiburan disebabkan oleh dihentikannya ritual sedekah bumi akibat kurang minat dan 
perubahan kepercayaan sebagian besar masyarakat yang tidak lagi menganut animisme dan dinamisme.

\subsection{Saran}

Saran kepada kelompok Sri Langen Budaya Bumi di Desa Pasigitan untuk tetap melestarikan Tari Opak Abang. Saran untuk bentuk pertunjukan Tari Opak Abang agar menambah variasi gerakan dengan tempo yang juga bervariasi agar pertunjukan terlihat lebih menarik, selain itu perlu dilakukan aransemen ulang untuk iringan Tari Opak Abang, misalnya dengan menambahkan alat musik kendhang atau seperangkat gamelan agar lebih terdengar meriah. Tari Opak Abang sebaiknya tidak hanya digunakan sebagai sajian hiburan, melainkan ditampilkan pada acara-acara tertentu, misalnya untuk kepentingan propaganda pada saat pemilu dan kampanye kepala daerah di Kabupaten Kendal, sehingga Tari Opak Abang memiliki agenda pertunjukan yang tetap. Para penari Opak Abang hendaknya lebih rutin berlatih agar semakin luwes dalam menari. Kostum Tari Opak Abang hendaknya diperbaharui kembali, karena banyak yang sudah mengalami kerusakan dan bahkan hilang, selain itu pemilihan warna kostum sebaiknya lebih bervariasi agar terlihat lebih menarik. Para pemusik Tari Opak Abang sebaiknya diregenerasi dengan kaum muda, karena usia para pemusik yang sudah lanjut usia. Regenerasi pelaku pertunjukan Tari Opak Abang sebaiknya segera dilakukan agar Tari Opak Abang mempunyai generasi penerus. 


\section{DAFTAR PUSTAKA}

Amalia, Nurul \& Bintang Hanggoro Putra. 2015. "Bentuk dan Fungsi Kesenian Tradisional Krangkeng di Desa Asemdoyong Kecamatan Taman Kabupaten Pemalang”. Jurnal Seni Tari. 4 (2): 1-12. Semarang: Universitas Negeri Semarang. (diunduh pada Jumat, 13 Januari 2017)

Arikunto, Suharsimi. 2010. Prosedur Penelitian Suatu Pendekatan Praktik. Jakarta: Rineka Cipta.

Cahyono, Agus. 2006. "Seni Pertunjukan Arak-Arakan Dalam Tradisional Dugderan Di Kota Semarang". Harmonia Jurnal Pengetahuan dan Pemikiran Seni Jurusan Sendratasik. VII (3) : 64-65. Semarang: Universitas Negeri Semarang.

Hartono. 2012. Pembelajaran Tari Anak Usia Dini. Semarang: UNNES Press.

Hoerburger, Felix. 1968. "Once Again: On The Concept of 'Folk Dance'". Journal of the International Folk Music Council. 20: 30-32. (diunduh pada Jumat, 13 Januari 2017)

Hoppu, Peter. 2014. "Folk Dancers Cross-Dressed: Performing Gender in the Early Nordic Folk Dance Movement". Journal of Folklore Research. 51 (3): 311-335. USA: Indiana University Press. (diunduh pada Jumat, 13 Januari 2017)

Horton, Paul B. \& Chester L. Hunt (Ed). 1984. Sosiologi. Edisi ke-6. Terjemahan Aminuddin Ram \& Tita Sobari. Jakarta: Erlangga.

Humphrey, Doris. 1983. The Art of Making Dances. Terjemahan Sal Murgiyanto. Jakarta: Dewan Kesenian Jakarta.

Ibrahim MA. 2015. Metodologi Penelitian Kualitatif. Bandung: Alfabeta

Jazuli, M. 2008. Pendidikan Seni Budaya Suplemen Pembelajaran Seni Tari. Semarang: UNNES Press.

Jazuli, M. 1994. Telaah Teoritis Seni Tari. Semarang: IKIP Semarang Press.

Kamila, Zumrotul Nala. 2016. Bentuk dan Fungsi Pertunjukan Tari Kuntulan Ulul Albab di Desa Dukuh Anggrung Kecamatan Sirampog Kabupaten Brebes. Skripsi. Semarang: Universitas Negeri Semarang.

Kusumaningrum, Prastiti Ade. 2016. Bentuk Pertunjukan Kuda Kepang Indang Puwosari di Desa Cindaga Kecamatan Kebasen Kabupaten Banyumas. Skripsi. Semarang: Universitas Negeri Semarang. 
Lestari, Wahyu. 1993. Teknologi Rias Panggung. Semarang: IKIP Semarang.

Maryono. 2011. Penelitian Kualitatif Seni Pertunjukan. Surakarta: ISI Press.

Martono, Hendro. 2012. Koreografi Lingkungan Revitalisasi Gaya Pemanggungan dan Gaya Penciptaan Seniman Nusantara. Yogyakarta: Cipta Media.

Miles, Matthew B. \& A. Michael Huberman. 1992. Analisis Data Kualitatif: Buku Sumber Tentang Metode-Metode Baru. Terjemahan Tjetjep Rohendi Rohidi. Jakarta: UI-Press.

Murgiyanto, Sal. 1992. Koreografi. Jakarta : Departemen Pendidikan dan Kebudayaan.

Murgiyanto, Sal. 1983. Koreografi Pengetahuan Dasar Komposisi Tari. Ed. Jakarta: Departemen Pendidikan dan Kebudayaan.

Nita, Cicilia Ika Rahayu. 2005. Bentuk dan Fungsi Pertunjukan Jathilan dalam Upacara Ritual Kirab Pusaka pada Masyarakat Kampung Tidar Warung Kelurahan Tidar Magelang. Tesis. Semarang: Universitas Negeri Semarang.

Pekerti, Widya. 2008. Metode Pengembangan Seni. Jakarta: Universitas Terbuka.

Pradewi, Sellyana dan Wahyu Lestari. 2012. "Eksistensi Tari Opak Abang Sebagai Tari Daerah Kabupaten Kendal”. Jurnal Seni Tari. 1:1-12. Semarang: Universitas Negeri Semarang. (diunduh pada Sabtu, 25 April 2015)

Prasetya, Irwan.H. 2010. Ensiklopedia Drama Dan Teater Indonesia. Semarang: Aneka Ilmu.

Rahayu, Dyah Sri. 2013. Kajian Bentuk dan Fungsi Pertunjukan Kesenian Lengger Budi Lestari Kecamatan Kledung Kabupaten Temanggung. Skripsi. Semarang: Universitas Negeri Semarang

Rahayu, Fitri. 2015. Kajian Estetis Koreografis Tari Gambyong Retno Kusumo di Sanggar Soerya Soemirat Kota Surakarta. Skripsi. Semarang: Universitas Negeri Semarang

Ratih, Endang. 2001. "Fungsi Tari sebagai Seni Pertunjukan". Harmonia Jurnal Pengetahuan dan Pemikiran Seni Jurusan Sendratasik. 2 (2) :67-77. Semarang: Universitas Negeri Semarang. (diunduh pada Jumat, 13 Januari 2017). 
Royce, Anya Peterson. 2007. Antropologi Tari. Terjemahan F.X. Widaryanto. Bandung: Sunan Ambu Press.

Sapitri, Ayuk Damar. 2016. "Bentuk dan Fungsi Pertunjukan Tari Mayang Rontek Kabupaten Mojokerto dalam Gelar Seni Budaya Daerah Jawa Timur di Taman Budaya Surabaya". APRON Jurnal Pemikiran Seni Pertunjukan. 2 (10). Surabaya: Universitas Negeri Surabaya. (diunduh pada Jumat, 3 Februari 2017)

Soedarsono. 1977. Tari-Tarian Indonesia. Jakarta: Proyek Pengembangan Media Kebudayaan, Ditjen Kebudayaan, Depdikbud.

Soekanto, Soerjono \& Budi Sulistyowati. 2014. Sosiologi Suatu Pengantar. Jakarta: Rajawali Pers.

Sugiyono. 2015. Metode Penelitian Tindakan Komprehensif. Bandung: Alfabeta.

Sukma, Rezali Canggih. 2013. Analisis Komposisi Musik Iringan Kesenian Opak Abang di Kabupaten Kendal. Skripsi .Semarang: Universitas Negeri Semarang.

Sulastuti, Katarina Indah. 2006. Notasi Tari I. Eds. Surakarta: ISI Press.

Sumarni, Nanik Sri. 2001. "Warna, Garis, dan Bentuk Ragam Hias dalam Tata Rias dan Tata Busana Wayang Wong Sri Wedarisurakarta sebagai Sarana Ekspresi. Harmonia Jurnal Pengetahuan dan Pemikiran Seni Jurusan Sendratasik." 2 (3) :39. Semarang: Universitas Negeri Semarang. (diunduh pada Sabtu, 16 Juli 2016)

Susetyo, Bagus. 2007. Pengkajian Seni Pertunjukan Indonesia. Semarang: Sendratasik FBS UNNES.

Trisakti. 2013. Bentuk dan Fungsi Pertunjukan Jaranan dalam Budaya Masyarakat Jawa Timur. Makalah disajikan dalam Prosiding The $5^{\text {th }}$ International Conference on Indonesian Studies: "Ethnicity and Globalization", Yogyakarta, 13-14 Juni.

Tuguatiningsih. 2013. Bentuk Pertunjukan Ebeg "Teater Janur" di Kecamatan Purwokerto Selatan Kabupaten Banyumas. Skripsi. Semarang: Universitas Negeri Semarang.

Utina, Usrek Tani dan Wahyu Lestari. 2006. "Efektivitas Pergelaran Tari bagi Mahasiswa Sendratasik Unnes". Harmonia Jurnal Pengetahuan dan Pemikiran Seni Jurusan Sendratasik. 7 (1) :14-22. Semarang: Universitas Negeri Semarang. (diunduh pada Sabtu, 25 April 2015) 
Ambarwangi, Sri; Suharto, Suharto. Reog as Means of Students' Appretiationand Creation in Arts and Culture Based on the Local Wisdom. Harmonia: Journal of Arts Research and Education, [S.1.], v. 14, n. 1, p. 37-45, Mar. 2014. ISSN 2541-2426. Available at: <https://journal.unnes.ac.id/nju/index.php/harmonia/article/view/2789>. Date accessed: $17 \quad 2018$. doi:http://dx.doi.org/10.15294/harmonia.v14i1.2789.

Bisri, M. (2011). Perkembangan Tari Ritual Menuju Tari Pseudoritual di Surakarta (The Development of Ritual Dance toward Pseudoritual Dance in Surakarta). Harmonia: Journal Of Arts Research And Education, 8(1). doi:http://dx.doi.org/10.15294/harmonia.v8i1.798

Suharto, S., \& Aesijah, S. (2014). THE LESUNG MUSIC IN THE VILLAGE OF LEDOK BLORA REGENCY. Harmonia: Journal Of Arts Research And Education, $14(1)$, 65-71. doi:http://dx.doi.org/10.15294/harmonia.v14i1.2851

Handayaningrum, W. (2016). Science-Based Thematic Cultural Art Learning in Primary School (2013 Curriculum). Harmonia: Journal Of Arts Research And Education, 16(1), 14-23. doi:http://dx.doi.org/10.15294/harmonia.v16i1.6766

Idris, M., Mustaffa, N., \& Yusoff, S. (2016). Preservation of Intangible Cultural Heritage Using Advance Digital Technology: Issues and Challenges. Harmonia: Journal Of Arts Research And Education, 16(1), 1-13. doi:http://dx.doi.org/10.15294/harmonia.v16i1.6353

Suharto, S. (2000). ACTION RESEARCH TO SOLVE MUSIC TEACHING PROBLEMS IN THE SCHOOL. Harmonia: Journal Of Arts Research And Education, 1(1). doi:http://dx.doi.org/10.15294/harmonia.v1i1.835

Suharto, S. (2011). Refleksi Teori Kritik Seni Holistik : sebuah Pendekatan Alternatif dalam Penelitian Kualitatif bagi Mahasiswa Seni (Reflection on Art Criticism and Holistic Art Criticism : an Alternative Approach of Qualitative Research for Art Students). Harmonia: Journal Of Arts Research And Education, 8(1). doi:http://dx.doi.org/10.15294/harmonia.v8i1.803

Soemaryatmi, -. (2011). Tari Slawatan Angguk Rame Ngargatantra : Kajian Sosiologis (Slawatan Angguk Rame Ngargatantra Dance : The Sociology Study). Harmonia: Journal Of Arts Research And Education, 8(1). doi:http://dx.doi.org/10.15294/harmonia.v8i1.802

Handayani, C. (2011). Bangkitnya Kembali Kesenian Tradisional Rakyat sebagai Warisan Budaya Nenek Moyang di Bukit Menoreh Bhumi Sabhara 
Budhara (The Re-animation of the Traditional Folk Arts as the Ancestors Cultural Heritage at Bukit Menoreh Bhumi Sambhara Budhara). Harmonia: Journal Of Arts Research And Education, 7(2). doi:http://dx.doi.org/10.15294/harmonia.v7i2.754

Kusumadewi, L., \& Suharto, S. (2011). PENINGKATAN HASIL BELAJAR SENI MUSIK DENGAN MEDIA AUDIO VISUAL MELALUI METODE BERVARIASI. Harmonia: Journal Of Arts Research And Education, 10(2). doi:http://dx.doi.org/10.15294/harmonia.v10i2.63

Widodo, -. (2011). LELAGON DOLANAN ANAK DAN PENDIDIKAN KARAKTER. Harmonia: Journal Of Arts Research And Education, 10(2). doi:http://dx.doi.org/10.15294/harmonia.v10i2.62

Indriyanto, -. (2011). KEBANGKITAN TARI RAKYAT DI DAERAH BANYUMAS (The Resurgence of Folk Dances in Banyumas). Harmonia: Journal Of Arts Research And Education, 2(2). doi:http://dx.doi.org/10.15294/harmonia.v2i2.853

Widoyoko, Eko Putro S. 2012. Teknik Penyusunan Instrumen Penelitian. Yogyakarta: Pustaka Pelajar.

Widyastutiningrum, Sri Rochana \& Dwi Wahyudiarto. 2014. Pengantar Koreografi. Surakarta: ISI Press. 


\section{GLOSARIUM}

Animisme

Bass drum

Blush On

Bow

Budaya

Bumi

Cepol

Ciffon

Confirmability

Credibility

Dangdut

Dependability

Digital

Dinamisme

Ekstern

Eyeliner
: kepercayaan terhadap benda-benda mati, seperti batu dan

pohon yang dianggap mempunyai roh di dalamnya

: alat tulis dengan isian tinta di dalamnya

: alat musik berbentuk tabung pipih yang besar

: perona pipi

: alat untuk menggesek senar biola

: Kebudayaan

: asli

: rambut yang digelung dengan ukuran kecil

: salah satu jenis kain yang bahannya tipis, halus, dan ringan

: kepastian

: kepercayaan

: aliran musik yang alat musik utamanya adalah kendhang

dan seruling

: kebergantungan

: sesuatu yang berhubungan dengan sistem perhitungan

tertentu

: kepercayaan terhadap roh-roh nenek moyang yang telah

meninggal

:dari luar

: pemberi garis warna pada tepi mata 


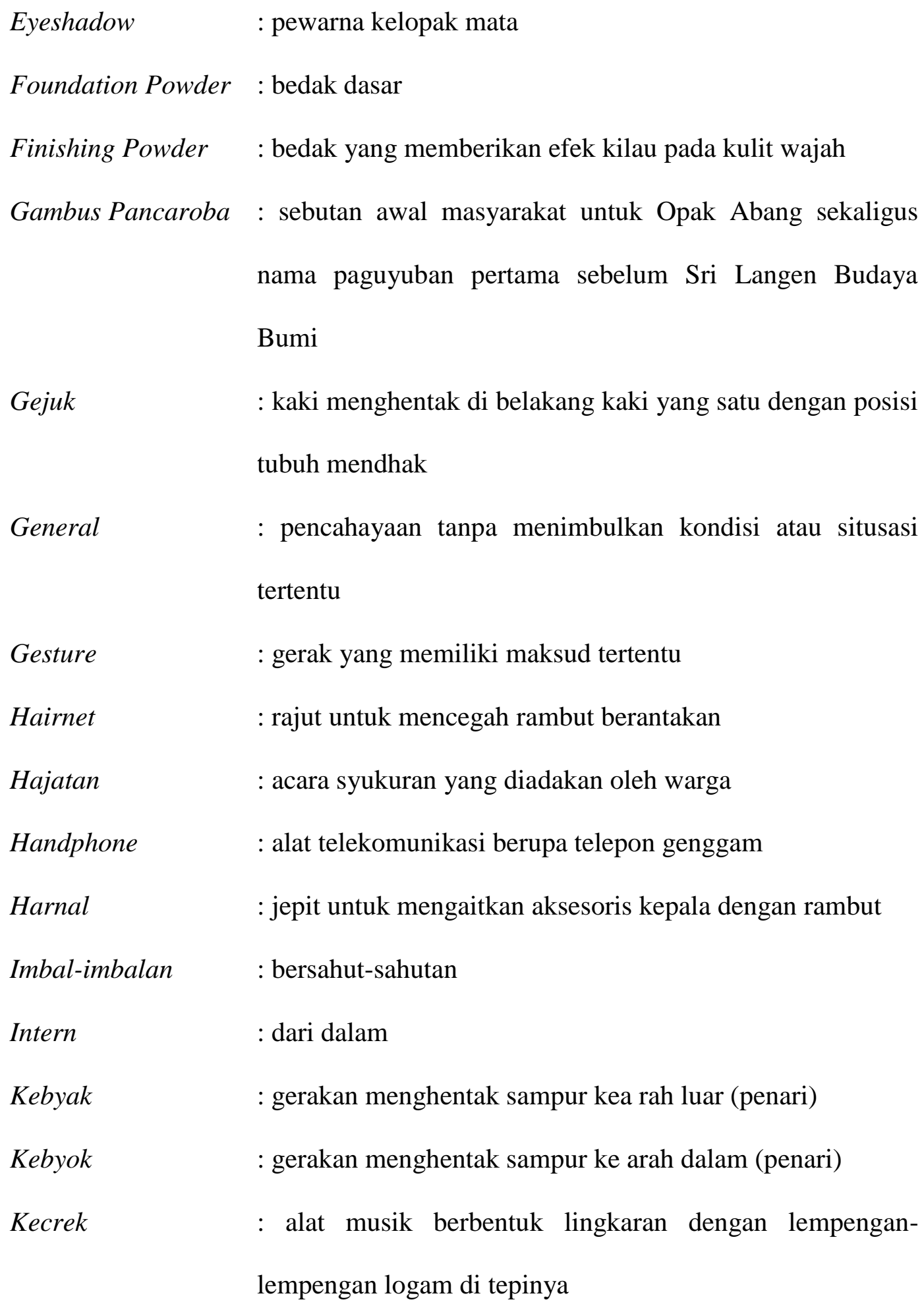


Kendhang

Kethoprak

Keyboard amplifier

: alat musik dari Pulau Jawa yang bagian tubuhnya menggunakan kayu, sedangkan bagian yang dipukul menggunakan bahan kulit binatang.

: drama tradisional asli dari Jawa Tengah

: komponen elektronika yang digunakan untuk menguatkan daya keyboard

Lambeyan

: gerakan melambaikan tangan

Langen

: kesenangan

Lighting

: pencahayaan

Lipstick

: pewarna bibir

Luwes

: gerakan tubuh yang gemulai ketika menari

Malangkrik

: tangan ditempelkan di pinggul

Mbah

: sebutan bahasa jawa untuk kakek/nenek

Mendhak

: posisi dasar penari dengan kedua lutut sedikit ditekuk membentuk huruf $\mathrm{O}$

Menthang

: tangan merentang ke samping kanan/kiri

Mentok

: hewan unggas

Miwir sampur

: tangan membawa sampur

Monoton

: tidak ada perubahan

Napak

: menapakkan kaki ke lantai

Ngila asta

: ragam gerak Tari Surakarta dengan sikap kedua tangan menyilang di depan wajah penari dan arah kedua telapak 
tangan menghadap ke dalam dengan kedua ibu jari saling berhimpitan

Ngrayung

: keempat jari lurus kecuali ibu jari yang ditekuk menempel

dengan telapak tangan

Njimpit sampur $\quad$ : jari tangan menjepit sampur di sela-sela

Ornament : : hiasan

Peach : salah satu jenis warna yang kalem/lembut

Plisir : : hiasan kepala Tari Opak Abang

Primer : utama

Pure Movement : gerak yang tidak memiliki maksud tertentu

Sampir sampur : sampur diletakkan di atas tangan

Sampur : selendang

Santosa Stable : : tempat wisata dekat Desa Pasigitan

Seblak sampur : : membuang sampur ke samping kanan/kiri

Sedekah bumi : upacara ritual yang dilakukan sebagai wujud syukur atas hasil panen padi

Sekunder : tambahan

Selempang : perlengkapan busana tari yang dipasang secara diagonal dari atas pundak hingga pinggul

Sesaji : beberapa makanan atau barang yang digunakan untuk sarana ritual

Setting : penempatan suatu subjek/objek dalam tari 
Shading

Sindhen

Slepe

Solmisasi

Sound system

Speaker

Spons

Sri

Staging

Syiar

Terbang

Tirakatan

Transferability

Trap Jamang

Ukel Karna

Ukel

Ulap-ulap

Wantah

Wiraga
: teknik untuk memberikan efek tirus pada bagian-bagian wajah tertentu

: penyanyi dalam iringan tari

: sabuk

: sistem nada do re mi fa sol la si do

: tata suara

: pengeras suara

: alat untuk membubuhkan bedak

: wanita

: pemanggungan

: penyebaran

: alat musik pukul, biasa disebut dengan rebana

: acara syukuran dalam rangka memperingati hari

kemerdekaan RI

: keteralihan

: memutar pergelangan tangan di samping telinga sambil tangan lainnya ulap-ulap

: memutar pergelangan tangan di samping telinga

: memutar pergelangan tangan $360^{\circ}$

: posisi seperti orang sedang melihat dengan satu tangan

diletakkan di depan alis

: gerak murni

: kemampuan penari dalam mengolah tubuhnya 
Wirama

Wirasa
: kemampuan penari dalam menyelaraskan antara gerak dan iringan

: kemampuan penari dalam mengekspresikan gerak-gerak tubuh :jaringan tanpa kabel

Wireless microphone : pengubah getaran suara menjadi getaran listrik tanpa kabel 
Lampiran 1

\section{INSTRUMEN PENELITIAN}

BENTUK DAN PERUBAHAN FUNGSI SENI PERTUNJUKAN TARI OPAK ABANG DESA PASIGITAN KECAMATAN BOJA KABUPATEN

KENDAL

\subsubsection{PEDOMAN OBSERVASI}

1.1 Gambaran umum Desa Pasigitan, meliputi:

1. Lokasi Desa Pasigitan

2. Kondisi geografis Desa Pasigitan

1.2 Bentuk Pertunjukan Tari Opak Abang, meliputi:

1. Tema

2. Gerak

3. Iringan

4. Tata rias dan busana

5. Tata pentas

6. Tata lampu

7. Tata suara

8. Pelaku/penari

9. Penonton

\section{PEDOMAN DOKUMENTASI}

2.1 Foto Pertunjukan

1. Foto rias dan busana 
2. Foto para pelaku seni pertunjukan Tari Opak Abang

2.2 Data wilayah dan kependudukan

1. Data wilayah Kecamatan Boja

2. Data wilayah Desa Pasigitan (letak dan kondisi geografis)

3. Data kependudukan Desa Pasigitan

2.3 Data pelaku kesenian Tari Opak Abang

1. Data riwayat hidup para pelaku kesenian Tari Opak Abang

2. Data prestasi atau penghargaan yang pernah diraih oleh Tari Opak Abang Desa Pasigitan

\section{PEDOMAN WAWANCARA}

3.1 Wawancara kepada Bapak Aris Salamun dan Ibu Pujiati

1. Apakah Tari Opak Abang itu?

2. Bagaimana sejarah dan perkembangan Tari Opak Abang?

3. Bagaimana bentuk pertunjukan Tari Opak Abang

4. Apa tema dari Tari Opak Abang?

5. Bagaimana gerak Tari Opak Abang?

6. Bagaimana iringan Tari Opak Abang?

7. Bagaimana tata rias dan busana Tari Opak Abang?

8. Bagaimana tata pentas Tari Opak Abang?

9. Bagaimana tata lampu Tari Opak Abang?

10. Bagaimana tata suara Tari Opak Abang?

11. Bagaimana urutan pertunjukan Tari Opak Abang?

12. Kapan dan dalam rangka apa saja Tari Opak Abang dipentaskan? 
13. Apa fungsi pertunjukan Tari Opak Abang di Desa Pasigitan?

3.2 Wawancara kepada masyarakat

1. Apa yang anda ketahui tentang Tari Opak Abang?

2. Bagaimana kesan anda setelah melihat seni pertunjukan Tari Opak Abang?

3. Apaharapan anda kedepan untuk pertunjukan Tari Opak Abang di Desa Pasigitan?

3.3 Wawancara kepada penari Opak Abang

1. Sejak kapan menjadi penari Opak Abang?

2. Apakah ada kesulitan dalam menarikan Opak Abang?

3. Berapa kali latihan Tari Opak Abang sebelum pentas?

4. Bagaimana kesan bisa menarikan Opak Abang?

3.4 Wawancara kepada pemusik Tari Opak Abang

1. Sejak kapan menjadi pemusik Tari Opak Abang?

2. Apa alat musik yang dimainkan?

3. Apakah ada kesulitan dalam mengiringi Tari Opak Abang?

4. Berapa kali latihan mengiringi Tari Opak Abang sebelum pentas?

5. Bagaimana kesan bisa mengiringi Tari Opak Abang? 


\section{Lampiran 2}

\section{HASIL WAWANCARA}

1. Narasumber: Bapak Aris Salamun, ketua grup Sri Langen Budaya Bumi Desa Pasigitan

Peneliti $(\mathrm{P}) \quad$ : Assalamualaikum, pak.

Bapak Aris (BA) : Waalaikumsalam, mbak.

P : Mohon maaf bolehkah saya meminta waktunya sebentar untuk wawancara tentang Tari Opak Abang, pak?

BA : Iya, mbak. Silahkan.

P : Pertama-tama, apa sebenarnya Tari Opak Abang itu, pak?

BA : Tari Opak Abang itu tari rakyat asli Desa Pasigitan, nama Opak Abang diambil dari kethoprak dan terbang. Masyarakat lebih mudah menyebutnya dengan Opak Abang.

$\mathrm{P} \quad$ : Kenapa diambil dari kethoprak dan terbang, pak?

BA : Karena Tari Opak Abang itu awalnya untuk pembukaan kethoprak, dan salah satu alat musik iringannya itu terbang atau rebana.

P : Bagaimana Tari Opak Abang bisa muncul di Dusun Siranti, Desa Pasigitan, pak?

BA : Berawal dari Bapak Kusno dari Desa Cepoko, Gunungpati yang menikah dengan orang Desa Pasigitan, lalu beliau 
mengembangkan Tari Opak Abang di sini pada tahun 1956, kemudian dilanjutkan oleh Bapak Kumisan, lalu Bapak Sapin, setelah itu baru saya sampai dengan sekarang. Awalnya belum masuk Dusun Siranti, tetapi di Dusun Sekargadung selama 3 tahun baru pada tahun 1959 masuk ke Siranti dan berkembang sampai sekarang. : Bagaimana gerakan Tari Opak Abang, pak?

BA : Gerakannya agak lambat, tetapi tidak ada nama-nama khusus untuk ragam geraknya. Penamaannya sesuai dengan judul-judul lagu yang mengiringi.

$\mathrm{P}$

: Kalau boleh tahu, apa saja judul-judul lagunya, pak?

BA : Gayung Seribu Gayung, Opak-opak, Terang Bulan, dan Bunga Rampai.

$\mathrm{P}$

: Apa tema pada Tari Opak Abang, pak?

BA : Sebenarnya kalau dilihat dari lirik lagu dan tata busana Tari Opak Abang, temanya tentang keagamaan dan perjuangan.

$\mathrm{P}$

: Iringan Tari Opak Abang menggunakan alat musik apa saja, pak?

BA : Terbang 2 buah, bass drum 1 buah, ketipung 1 buah, biola 1 buah, dan kecrek 1 buah.

: Apakah ada sindhen dalam iringan Tari Opak Abang?

BA : Ada, sindhen-nya 1 orang, istri saya. 
: Bagaimana pementasan Tari Opak Abang, pak?

BA

: Tari Opak Abang dipentaskan di halaman depan rumah saya dengan menggelar karpet sebagai alas. Pementasannya dilaksanakan malam hari karena lebih mudah untuk menarik perhatian penonton.

$\mathrm{P}$

: Bagaiamana tata lampu pertunjukan Tari Opak Abang, pak?

BA : Pencahayaannya menggunakan lampu putih yang cerah 2 buah di sudut kanan dan kiri area pertunjukan, dan lampu bohlam putih 1 buah di tengah atas area pertunjukan.

$\mathrm{P}$ : Bagaiamana tata suara pertunjukan Tari Opak Abang, pak?

BA : Sound system yang digunakan wireless untuk wireless microphone-nya sindhen, keyboard amplifier untuk biola, dan wireless microphone untuk sindhen.

$\mathrm{P}$ : Berapa jumlah pelaku seni pertunjukan Tari Opak Abang?

BA : Penari ada 4 orang, semuanya perempuan, pemusik ada 6 orang, semuanya laki-laki, dan sindhen 1 orang perempuan. : Bagaimana urutan pertunjukan Tari Opak Abang, pak?

BA : Sesuai dengan urutan judul lagunya, yaitu Gayung Seribu Gayung, Opak-opak, Terang Bulan, dan Bunga Rampai. waktunya untuk wawancara. 
BA : Sama-sama, mbak. Terima kasih kembali.

2. Narasumber: Ibu Pujiati, sindhen dan semasa muda menjadi penari Opak Abang

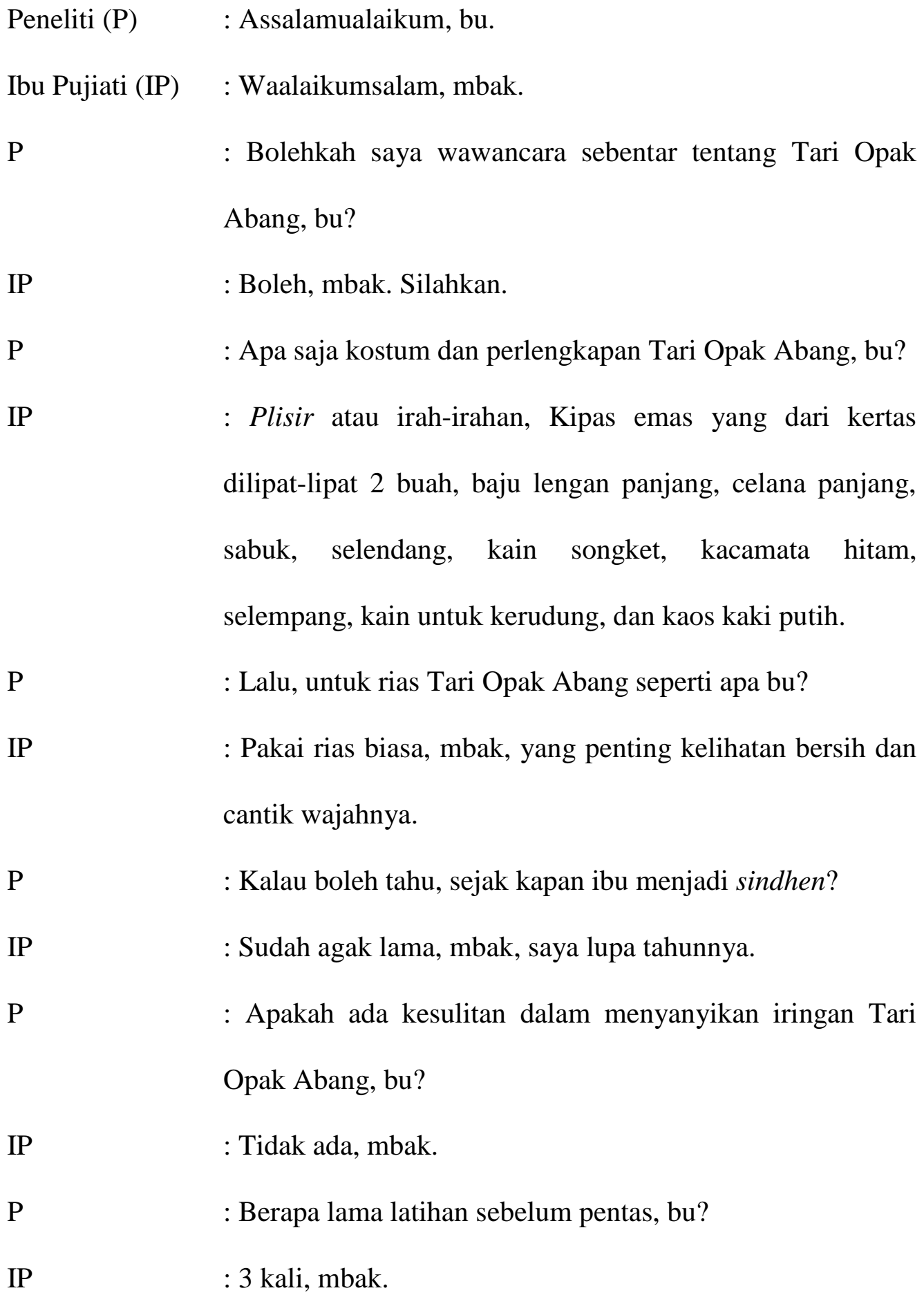




\section{Narasumber: Bapak Madasum, pemusik Tari Opak Abang}

Peneliti (P)

Bapak Madasum (BM)

$\mathrm{P}$

$\mathrm{P}$

$\mathrm{BM}$

$\mathrm{P}$

$\mathrm{BM}$

$\mathrm{P}$

$\mathrm{BM}$

$\mathrm{P}$

$\mathrm{P}$

$\mathrm{BM}$

$\mathrm{P}$
: Assalamualaikum, pak.

: Waalaikumsalam, mbak, bagaimana?

: Saya minta izin untuk bertanya-tanya sedikit tentang Opak Abang, bolehkah pak?

: Oh, silahkan, mbak.

: Sejak kapankah bapak bergabung di Opak Abang?

: Wah, sejak muda sudah ikut, mbak, saya lupa tahunnya. Sudah lama sekali.

: Kalau boleh tahu, berapa usia bapak sekarang?

: 53 tahun.

: Alat musik apa yang bapak mainkan?

: Saya pegang biola, mbak.

: Ketika mengiringi Tari Opak Abang ada kesulitan, pak?

: Alhamdulillah tidak ada, mbak.

: Sebelum pentas, sudah latihan berapa kali pak?

: 3 kali, mbak.

: Apa kesan bapak bisa mengiringi Tari Opak Abang? 
$\mathrm{BM}$

$\mathrm{P}$

$\mathrm{BM}$
: Senang sekali, mbak, karena saya dari dulu senang dengan seni tradisi.

: Oh, kalau begitu terima kasih banyak pa katas waktunya.

: Iya, mbak, sama-sama.

\section{Narasumber: Heni, penari Opak Abang}

Peneliti (P) : Assalamualaikum, permisi, mbak.

Heni $(\mathrm{H}) \quad$ : Waalaikumsalam, mbak.

$\mathrm{P}$

: Mbak, penari Opak Abang, ya?

$\mathrm{H}$

: Iya, mbak, bagiamana?

$\mathrm{P}$

: Boleh saya wawancara sebentar?

$\mathrm{H}$

: Boleh, mbak.

$\mathrm{P}$

: Sejak kapan ikut Opak Abang?

$\mathrm{H}$

: Kapan, ya? Sejak tahun lalu saya sudah sering ikut tampil, mbak.

$\mathrm{P}$

: Sekarang usianya berapa mbak?

$\mathrm{H}$

: 18 tahun

$\mathrm{P}$

: Siapa yang melatih saat latihan Tari Opak Abang?

$\mathrm{H}$

: Pak Riyanto, mbak.

$\mathrm{P}$

: Adakah kesulitan saat menarikan Opak Abang?

$\mathrm{H}$

: Kesulitannya tidak ada, mbak.

$\mathrm{P}$

: Latihannya berapa kali sebelum pentas? 
$\mathrm{H}$

$\mathrm{P}$

$\mathrm{H}$

$\mathrm{P}$

$\mathrm{H}$

: 4 kali, mbak.

: Bagaimana kesannya bisa menarikan Opak Abang?

: Kalau saya senang menari dari kecil, mbak, jadi saat menarikan Opak Abang saya merasa sangat senang.

: Kalau begitu, terima kasih atas kesediaan untuk wawancaranya.

: Oh, iya mbak, sama-sama.

\section{Narasumber: Ibu Siamah, penonton pertunjukan Tari Opak Abang}

Peneliti (P) : Permisi, bu, boleh wawancara sebentar?

Ibu Siamah (IB) : Iya, mbak, boleh.

$\mathrm{P} \quad$ : Ibu sudah melihat pertunjukan Tari Opak Abang?

IB : Iya mbak, sudah, bagaimana mbak?

P : Bagaimana kesan ibu setelah melihat pertunjukan Tari Opak Abang?

IB

: Kesan saya, Tari Opak Abang baik dan bagus, hanya saja penarinya kurang luwes sedikit, tetapi saya tetap senang melihatnya.

$\mathrm{P}$

: Apakah ibu tertarik dengan pertunjukan tadi?

IB

: Sangat tertarik, dulu saya pernah ikut menari waktu masih muda

$\mathrm{P}$

: Oh, kalau boleh tahu dulu ibu bergabung dengan Tari Opak Abang di usia berapa? 
: Dulu saya usia SD sudah ikut mbak, tetapi sekarang sudah tidak lagi, sudah tidak muda lagi.

$\mathrm{P}$

: Apa harapan ibu untuk Tari Opak Abang kedepannya?

IB

: Ya..semoga semakin baik dan tetap lestari, tidak hilang.

$\mathrm{P}$

: Baik, bu, terima kasih atas kesediaan waktu untuk wawancara

IB : Iya mbak, sama-sama. 


\section{Lampiran 3}

\section{PROFIL NARASUMBER}

1. Ketua Grup Sri Langen Budaya Bumi

$\begin{array}{ll}\text { Nama } & \text { : Aris Salamun } \\ \text { Usia } & : 56 \text { tahun } \\ \text { Jenis Kelamin } & \text { : Pria } \\ \text { Pendidikan } & \text { : SLTA } \\ \text { Pekerjaan } & \text { : Petani } \\ \text { Alamat } & \text { : Dusun Siranti RT 02 RW 08, Desa Pasigitan. }\end{array}$

2. Sindhen

$\begin{array}{ll}\text { Nama } & \text { : Pujiati } \\ \text { Usia } & : 51 \text { tahun } \\ \text { Jenis Kelamin } & \text { : Wanita } \\ \text { Pendidikan } & \text { : SLTA } \\ \text { Pekerjaan } & \text { : Ibu Rumah Tangga } \\ \text { Alamat } & \text { : Dusun Siranti RT 02 RW 08, Desa Pasigitan. }\end{array}$

3. Penari

$\begin{array}{ll}\text { Nama } & \text { : Puput Fajar Aprilia } \\ \text { Usia } & : \text { 15 Tahun } \\ \text { Jenis Kelamin } & : \text { Wanita }\end{array}$


Pendidikan : SMA/Sederajat

Pekerjaan : Pelajar

Alamat : Dusun Siranti RT 01 RW 08, Desa Pasigitan.

4. Penari

Nama $\quad$ : Heni Fatmawati

Usia $\quad: 18$ tahun

Jenis Kelamin : Wanita

Pendidikan : -

Pekerjaan $\quad:-$

Alamat : Dusun Siranti RT 01 RW 08, Desa Pasigitan.

5. Penari

Nama : Tania Febriyanti

Usia $\quad: 14$ tahun

Jenis Kelamin : Wanita

Pendidikan $\quad$ : SMP

Pekerjaan : Pelajar

Alamat : Dusun Siranti RT 02 RW 08, Desa Pasigitan.

6. Penari

$\begin{array}{ll}\text { Nama } & : \text { Eko Diharti } \\ \text { Usia } & : 35 \text { tahun }\end{array}$


Jenis Kelamin : Wanita

Pendidikan $\quad:$ S1

Pekerjaan : Karyawan swasta

Alamat : Dusun Siranti RT 02 RW 08, Desa Pasigitan.

7. Pemain bass drum

$\begin{array}{ll}\text { Nama } & : \text { Ngatman } \\ \text { Usia } & : 47 \text { tahun } \\ \text { Jenis Kelamin } & : \text { Pria } \\ \text { Pendidikan } & : \text { SD } \\ \text { Pekerjaan } & \text { : Wiraswasta } \\ \text { Alamat } & \text { : Dusun Siranti RT 02 RW 08, Desa Pasigitan. }\end{array}$

8. Pemain ketipung

Nama $\quad$ : Daryanto

Usia : 63 tahun

Jenis Kelamin : Pria

Pendidikan $\quad:$ SD

Pekerjaan : Petani

Alamat : Dusun Siranti RT 01 RW 08, Desa Pasigitan.

9. Pemain rebana

Nama $\quad$ : Ariyadi 
Usia

: 42 tahun

Jenis Kelamin : Pria

Pendidikan $\quad:$ SD

Pekerjaan : Wiraswasta

Alamat : Dusun Siranti RT 02 RW 08, Desa Pasigitan.

10. Pemain biola

$\begin{array}{ll}\text { Nama } & : \text { Madasum } \\ \text { Usia } & : 53 \text { tahun } \\ \text { Jenis Kelamin } & \text { : Pria } \\ \text { Pendidikan } & : \text { SD } \\ \text { Pekerjaan } & : \text { Petani } \\ \text { Alamat } & : \text { Dusun Siranti RT 02 RW 08, Desa Pasigitan. }\end{array}$

11. Pemain kecrek

$\begin{array}{ll}\text { Nama } & \text { : Mustaqim } \\ \text { Usia } & : \text { :35 tahun } \\ \text { Jenis Kelamin } & \text { : Pria } \\ \text { Pendidikan } & : \text { SD } \\ \text { Pekerjaan } & : \text { Pekerja bangunan } \\ \text { Alamat } & \text { : Dusun Siranti RT 02 RW 08, Desa Pasigitan. }\end{array}$


12. Pemain rebana

$\begin{array}{ll}\text { Nama } & \text { : Supriyadi } \\ \text { Usia } & : 53 \text { tahun } \\ \text { Jenis Kelamin } & : \text { Pria } \\ \text { Pendidikan } & : \text { SD } \\ \text { Pekerjaan } & : \text { Petani } \\ \text { Alamat } & : \text { Dusun Siranti RT 01 RW 08, Desa Pasigitan. }\end{array}$

13. Pelatih tari

$\begin{array}{ll}\text { Nama } & : \text { Riyanto } \\ \text { Usia } & : 37 \text { tahun } \\ \text { Jenis Kelamin } & : \text { Pria } \\ \text { Pendidikan } & : \text { S } 1 \\ \text { Pekerjaan } & : \text { Guru }\end{array}$

Alamat : Dusun Siranti RT 01 RW 08, Desa Pasigitan.

14. Penonton

$\begin{array}{ll}\text { Nama } & \text { : Siamah } \\ \text { Usia } & : 43 \text { tahun } \\ \text { Jenis Kelamin } & : \text { Wanita } \\ \text { Pendidikan } & : \text { SD } \\ \text { Pekerjaan } & \text { :Ibu Rumah Tangga }\end{array}$


Alamat

: Dusun Siranti RT 01 RW 08, Desa Pasigitan.

15. Penonton

$\begin{array}{ll}\text { Nama } & : \text { Purwati } \\ \text { Usia } & : 60 \text { tahun } \\ \text { Jenis Kelamin } & : \text { Wanita } \\ \text { Pendidikan } & :- \\ \text { Pekerjaan } & : \text { Petani } \\ \text { Alamat } & : \text { Dusun Siranti RT 02 RW 08, Desa Pasigitan. }\end{array}$

16. Penonton

$\begin{array}{ll}\text { Nama } & \text { : Ponirah } \\ \text { Usia } & : \text { 45 tahun } \\ \text { Jenis Kelamin } & \text { : Wanita } \\ \text { Pendidikan } & : \text { SD } \\ \text { Pekerjaan } & : \text { Buruh } \\ \text { Alamat } & \text { : Dusun Siranti RT 02 RW 08, Desa Pasigitan. }\end{array}$

17. Penonton

$\begin{array}{ll}\text { Nama } & : \text { Ratno } \\ \text { Usia } & : 60 \text { tahun } \\ \text { Jenis Kelamin } & : \text { Pria } \\ \text { Pendidikan } & :- \\ \text { Pekerjaan } & : \text { Petani }\end{array}$


Alamat

18. Penonton

Nama

Usia

Jenis Kelamin

Pekerjaan

Alamat

Semarang.

19. Partsipan

Nama

Usia

Jenis Kelamin

Pekerjaan

Alamat

Semarang
: Dusun Siranti RT 01 RW 08, Desa Pasigitan.

: Nimas Agustin Purwaningtyas

: 22 tahun

: Wanita

: Pelajar/Mahasiswa

: Gang Sirandu, Sekaran, Kecamatan Gunungpati, Kota

: 22 tahun

: Pria

: Pelajar/Mahasiwa

: Gang Kenanga, Sekaran, Kecamatan Gunungpati, Kota 


\section{Lampiran 4}

\section{FOTO}

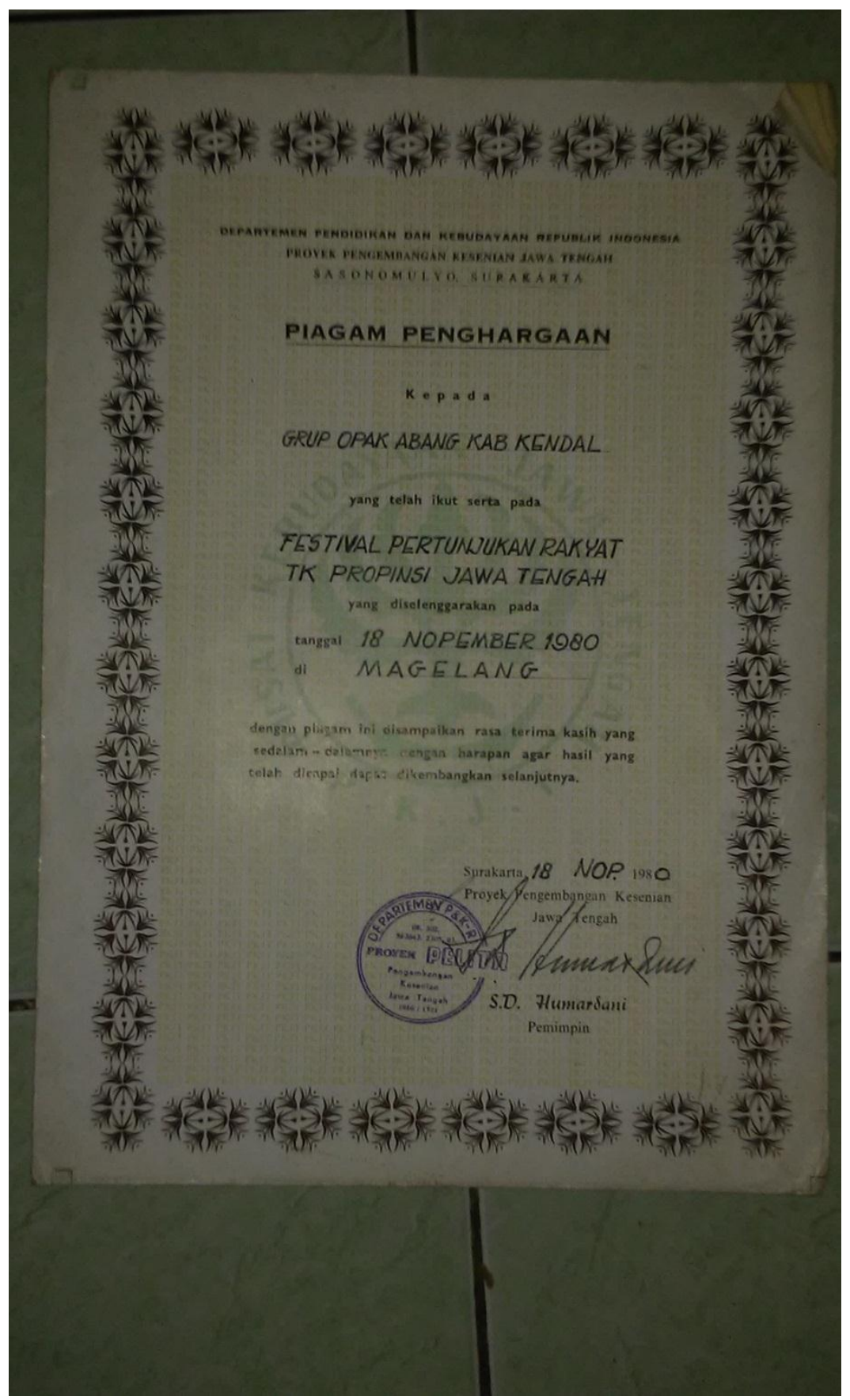

Foto 1. Piagam penghargaan Tari Opak Abang tingkat Provinsi Jawa Tengah (Sumber: Dokumentasi Saputra, 14 Januari 2016) 


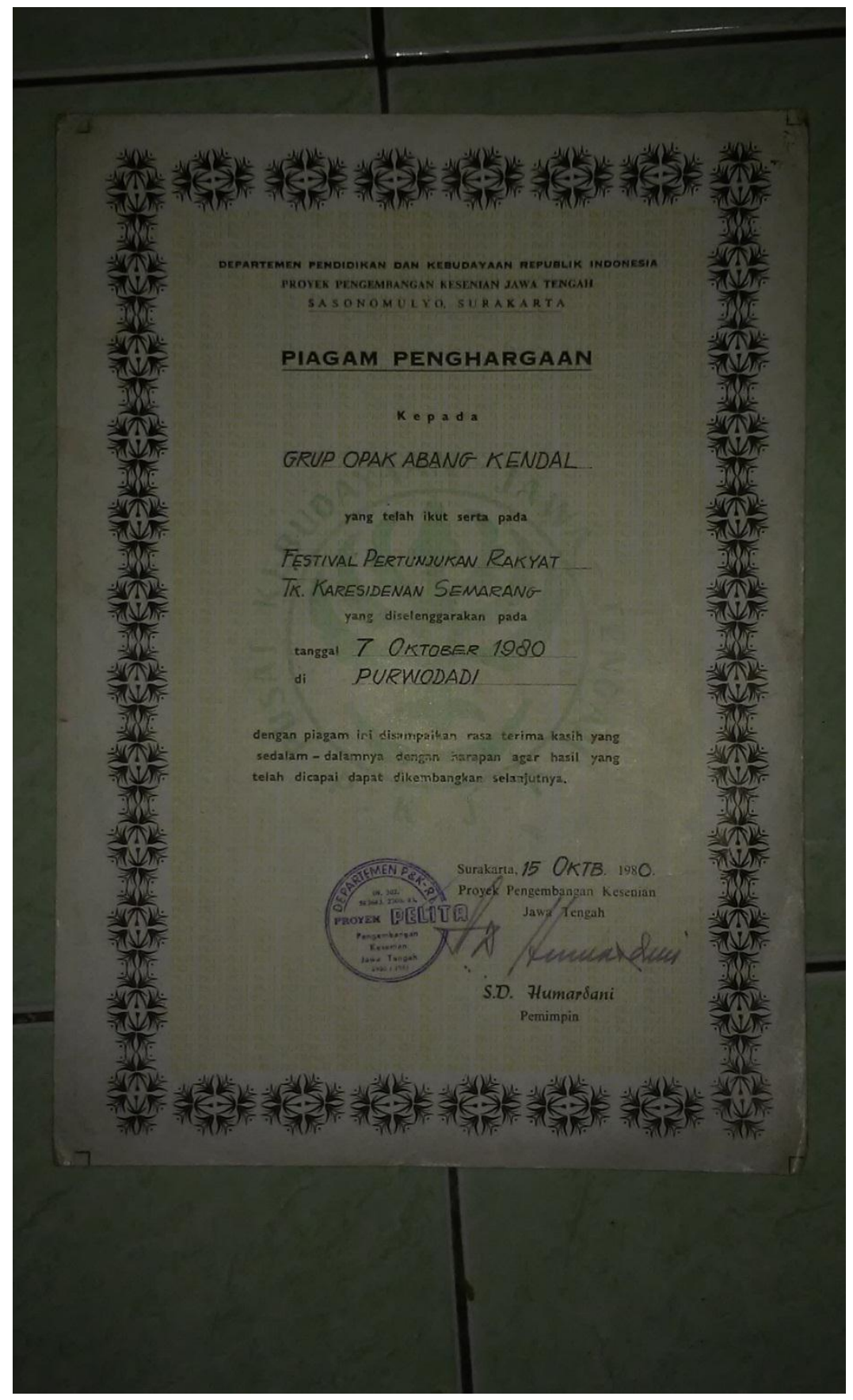

Foto 2. Piagam penghargaan Tari Opak Abang tingkat Karesidenan Semarang (Sumber: Dokumentasi Saputra, 14 Januari 2017) 


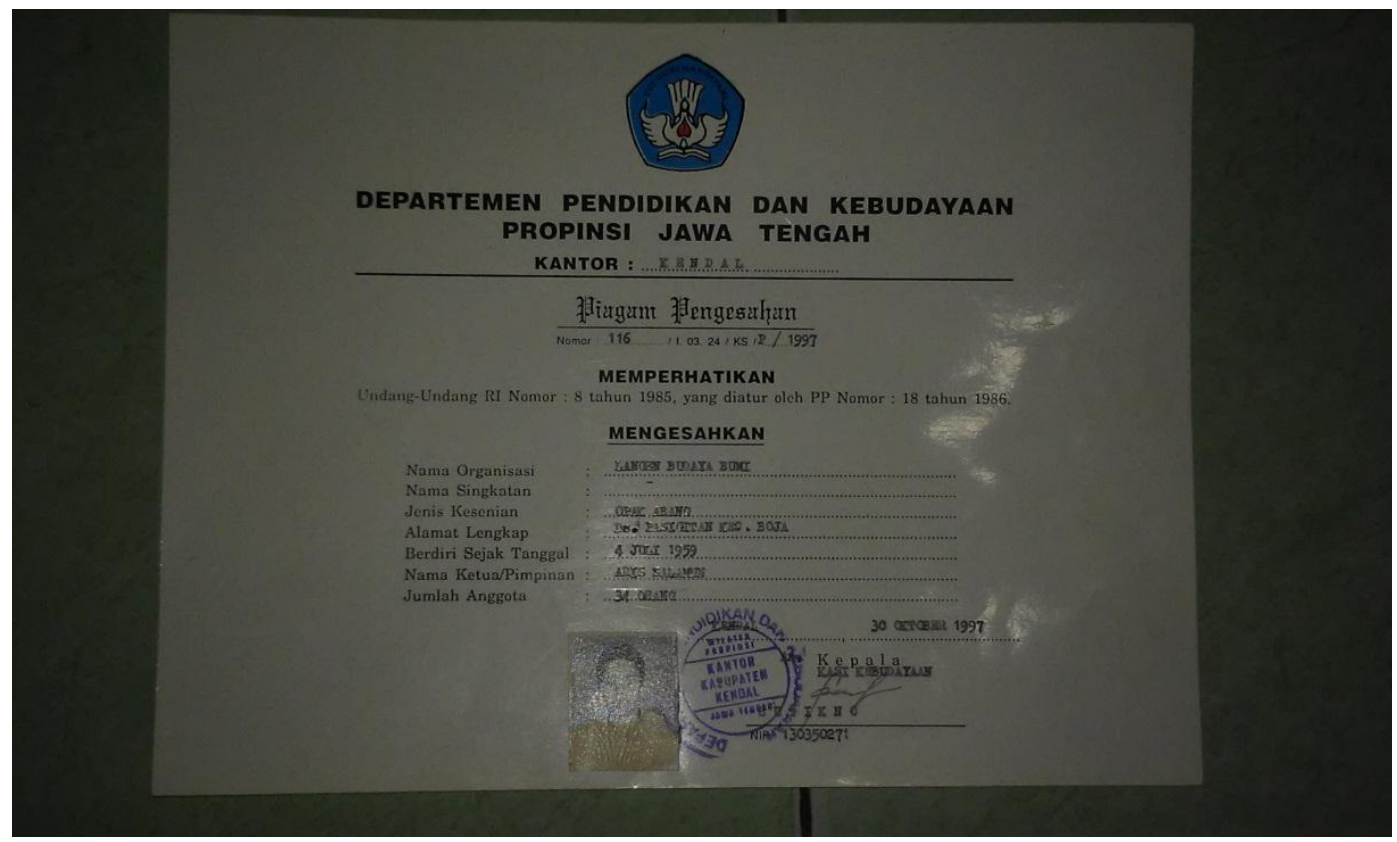

Foto 3. Piagam Penghargaan Pemerintah untuk grup Sri langen Budaya Bumi tahun 1997

(Sumber: Dokumentasi Saputra, 14 Januari 2016)

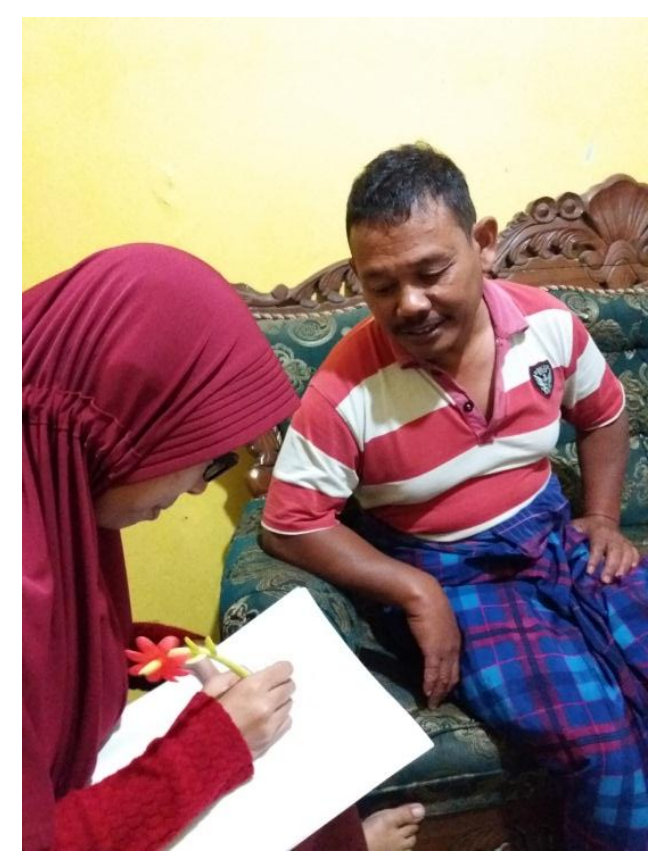

Foto 4. Peneliti mewawancarai Bapak Aris Salamun (Sumber: Dokumentasi Mawasti, 21 April 2017) 


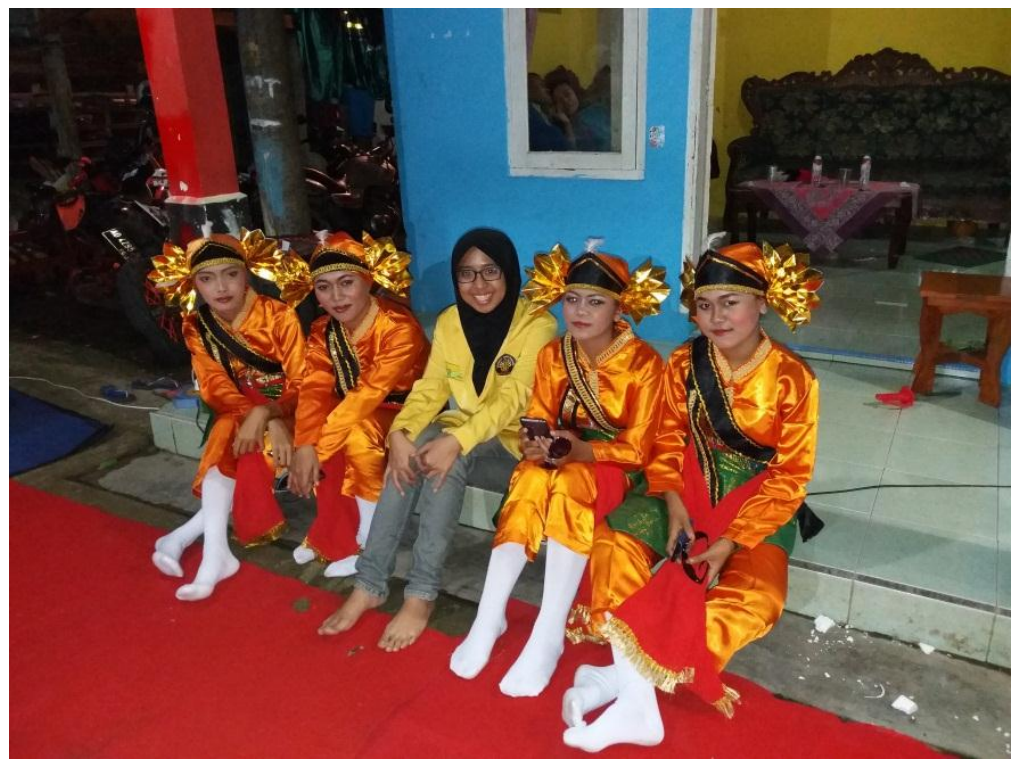

Foto 5. Peneliti bersama 4 penari Opak Abang

(Sumber: Dokumentasi Mawasti, 22 April 2017)

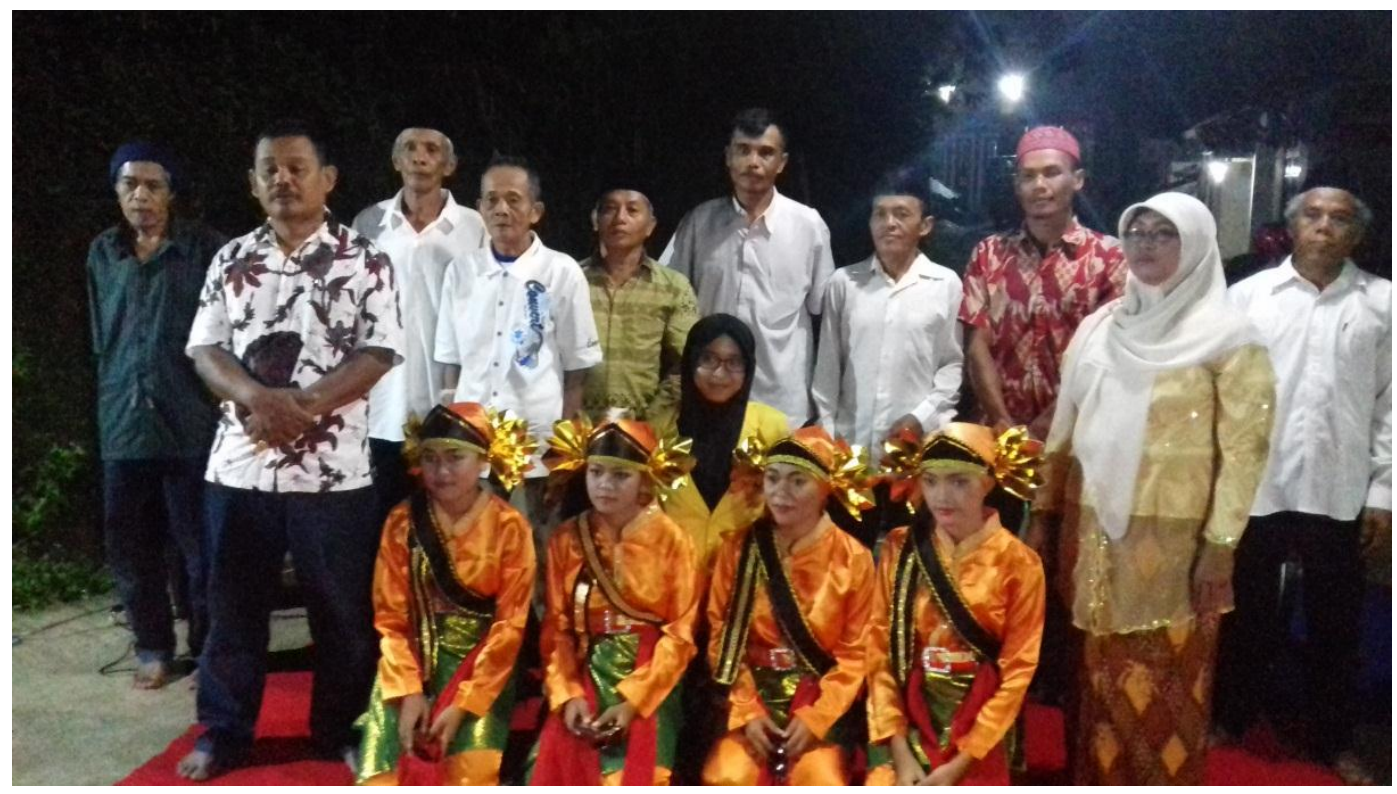

Foto 6. Peneliti bersama seluruh pelaku pertunjukan Tari Opak Abang (Sumber: Dokumentasi Mawasti, 22 April 2017) 


\section{Lampiran 5}

\section{SK Dosen Pembimbing}

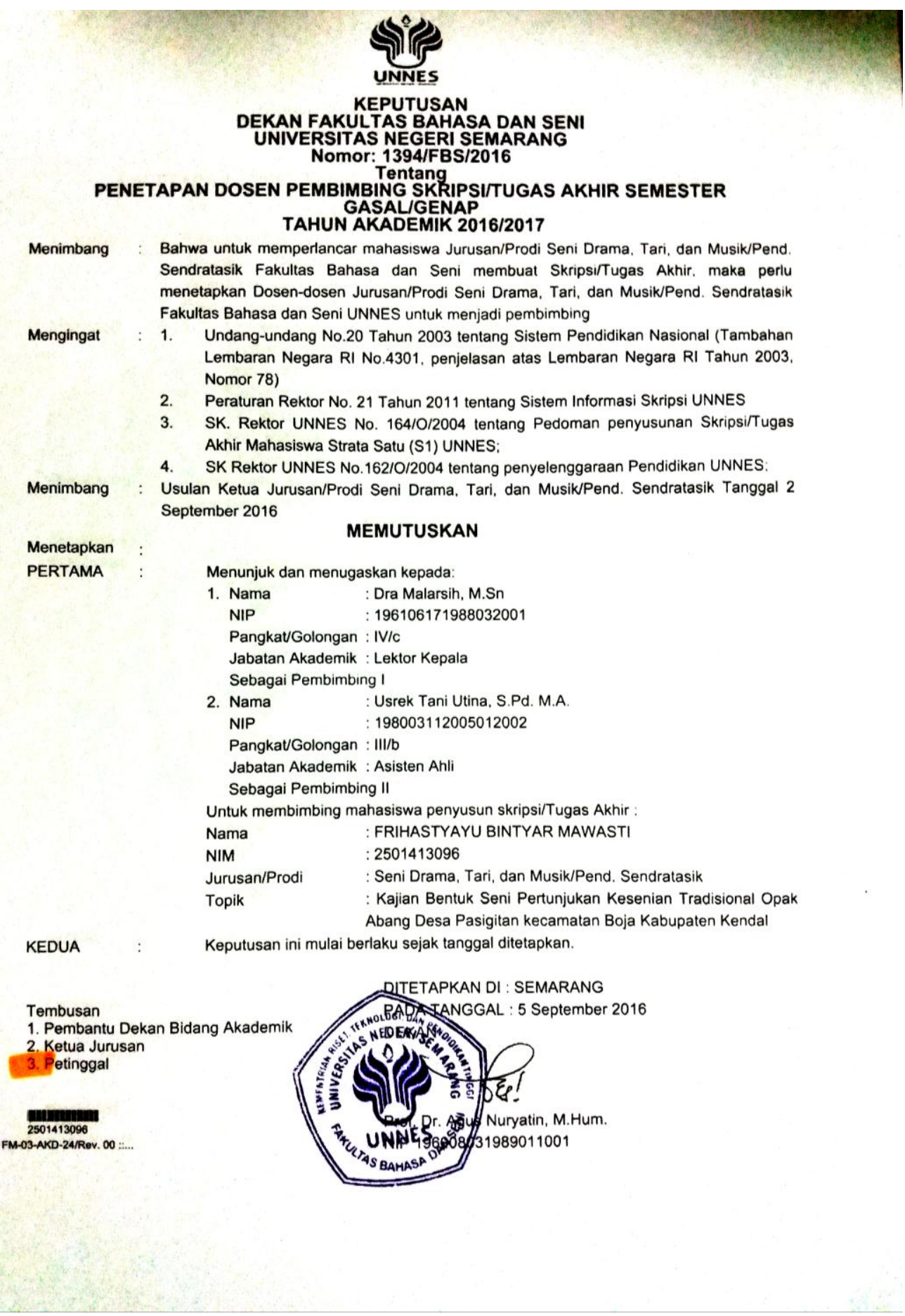




\section{Lampiran 6}

\section{Surat Permohonan Izin Penelitian}

KEMENTERIAN RISET, TEKNOLOGI, DAN PENDIDIKAN TINGGI
UNIVERSITAS NEGERI SEMARANG
FAKULTAS BAHASA DAN SENI

\footnotetext{
Nomor :124...JN37.1.2/LT/2017

Lamp. :-
}

Hal. : Permohonan Izin Penelitian

Yth. Kepala Desa Pasigitan, Boja Kab. Kendal

di tempat

Dengan hormat kami beritahukan bahwa dalam rangka penyusunan skripsi mahasiswa kami,

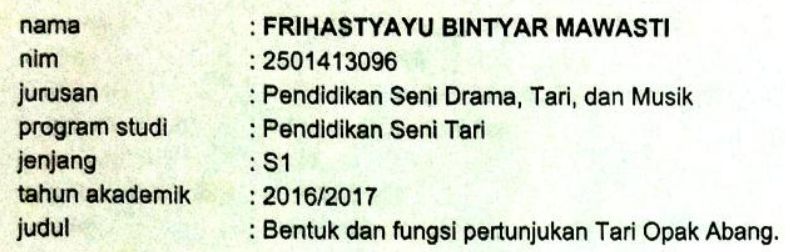

akan mengadakan penelitian di Desa Pasigitan Kecamatan Boja Kabupaten Kendal, waktu pelaksanaan Januari 2017 s.d. Februari 2017. Untuk itu kami mohon Saudara berkenan memberikan izin kepada mahasiswa di atas untuk keperluan tersebut.

Atas perhatian dan kerja sama Saudara, kami sampaikan terima kasih.

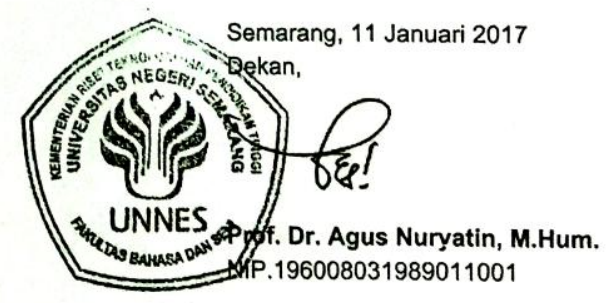

Tembusan:

1. Pembantu Dekan Bidang Akademik

2. Ketua Jurusan

3. Pertinggal 


\section{Lampiran 7}

\section{Surat Keterangan Telah Melaksanakan Penelitian}

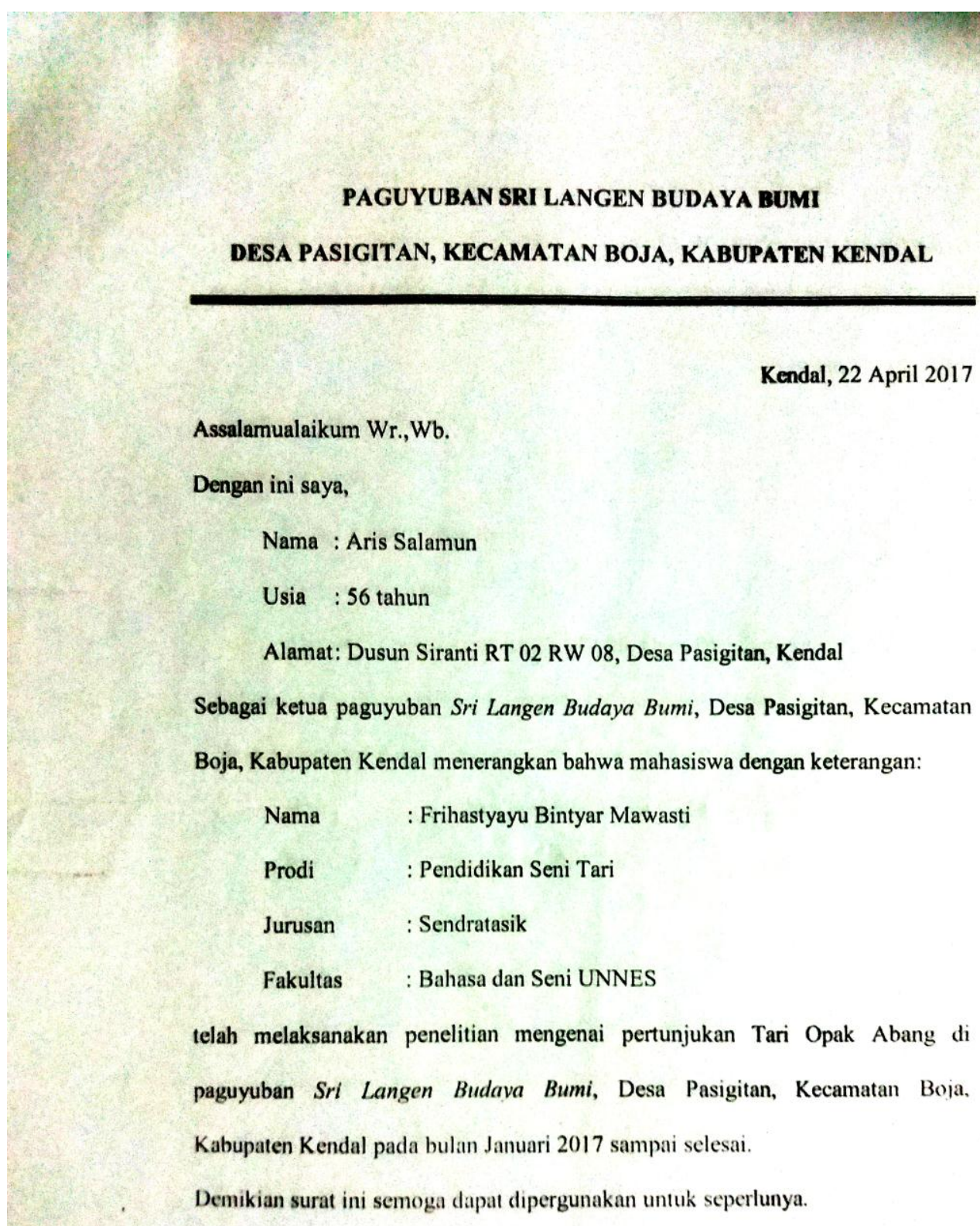

Ketua Paguyuban Sri Langep Butang Bumi

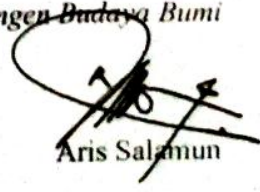

